ANDRÉA DE OLIVEIRA SILVA

\title{
RELAÇÕES USUÁRIO-PRODUTOR E APRENDIZADO INOVATIVO EM SISTEMAS LOCAIS DE PRODUÇÃO: UMA ANÁLISE DE INTERAÇÕES NA INDÚSTRIA DE MÁQUINAS PARA CALÇADOS E SEUS USUÁRIOS.
}


ANDRÉA DE OLIVEIRA SILVA

\section{RELAÇÕES USUÁRIO-PRODUTOR E APRENDIZADO INOVATIVO EM SISTEMAS LOCAIS DE PRODUÇÃO: UMA ANÁLISE DE INTERAÇÕES NA INDÚSTRIA DE MÁQUINAS PARA CALÇADOS E SEUS USUÁRIOS.}

Dissertação apresentada à Escola Politécnica da Universidade de São Paulo para a obtenção do título de Mestre em Engenharia.

São Paulo 


\section{RELAÇÕES USUÁRIO-PRODUTOR E APRENDIZADO INOVATIVO EM SISTEMAS LOCAIS DE PRODUÇÃO: UMA ANÁLISE DE INTERAÇÕES NA INDÚSTRIA DE MÁQUINAS PARA CALÇADOS E SEUS USUÁRIOS.}

Dissertação apresentada à Escola Politécnica da Universidade de São Paulo para a obtenção do título de Mestre em Engenharia.

Área de Concentração:

Engenharia de Produção

Orientador: Professor Doutor

Renato de Castro Garcia

São Paulo 
Este exemplar foi revisado e alterado em relação à versão original, sob responsabilidade única do autor e com a anuência de seu orientador.

São Paulo, de dezembro de 2007.

Assinatura do autor:

Assinatura do orientador:

FICHA CATALOGRÁFICA - Edição revisada

Silva, Andréa de Oliveira

Relações usuário-produtor e aprendizado inovativo em sistemas locais de produção: uma análise de interações na indústria de máquinas para calçados e seus usuários / A.O. Silva. -São Paulo, 2007. $231 \mathrm{p}$.

Dissertação (Mestrado) - Escola Politécnica da Universidade de São Paulo. Departamento de Engenharia de Produção.

1.Clusters 2.Localização industrial 3.Indústria de bens de capital 4.Aprendizagem tecnológica I.Universidade de São Paulo. Escola Politécnica. Departamento de Engenharia de Produção II.t. 
Aos queridos Valdeci e Conceição. 


\section{AGRADECIMENTOS}

Agradeço às pessoas que contribuíram para a realização da pesquisa e àquelas que têm participado da trajetória de aprendizado acadêmico e de vida.

Em primeiro lugar, agradeço aos meus pais e meus irmãos, pelo carinho e o apoio sem restrições.

Agradeço a CAPES pela bolsa concedida, que possibilitou o desenvolvimento do trabalho.

Agradeço aos professores do departamento de engenharia de produção, pela oportunidade de ampliar os conhecimentos. E aos funcionários e colaboradores da Poli, pelo apoio e assistência em vários momentos.

Agradeço aos professores e alunos do GEEIN, pela amizade e o aprendizado obtido nas reuniões acadêmicas e nos momentos de descontração. $E$ aos amigos da sala da pós, que compartilharam comigo as preocupações e as conquistas na fase de elaboração do trabalho.

Agradeço ao professor Alceu, pelos comentários de grande importância para a pesquisa. Ao professor João Furtado, pelas observações, sugestões e o apoio que foram fundamentais para o meu aprendizado acadêmico. E principalmente, ao professor Renato Garcia, pela dedicação nas leituras e discussões conceituais, por sua paciência e pela valiosa ajuda em todas as fases da pesquisa.

Agradeço ao professor Enio Klein (ABICALÇADOS), pelos ricos comentários sobre o setor de calçados. Ao Sr. Marcelo Adriano e à Patrícia Freitas (ABRAMEQ), que apresentaram aspectos relevantes do desenvolvimento do setor de máquinas. Ao Alessandro Carloni (IPT), pelos comentários e por sua colaboração no SLP de Franca. Aos Srs. Sérgio Knorr e Paulo Model (IBTec), que apontaram os fatores relevantes da dinâmica tecnológica e comercial da cadeia de calçados. Ao Sr. Paulo Humman (CETA - SENAI) e aos professores Achyles Barcelos, Janaína Ruffoni e Maria Cristina Passos (UNISINOS), por suas sugestões de pesquisa.

Agradeço, especialmente, aos representantes das empresas de máquinas (Poppi, Ivomaq, Kehl, Mecsul, ERPS, Master, Klein, Himaco e Irmãos Zambelli) e aos representantes das empresas de calçados (Via UNO, Tchocco, Ferraroni e Biaggio), por sua contribuição para a análise das interações usuário-produtor ao longo da cadeia. Por fim, agradeço a todos os funcionários das instituições de pesquisa e de apoio ao setor que colaboraram com o levantamento de informações setoriais. 


\section{RESUMO}

Este trabalho analisa a competitividade das empresas de bens de capital para calçados a partir das interações usuário-produtor nos dois principais sistemas locais de produção de calçados no Brasil, o Vale dos Sinos (RS) e Franca (SP). Desse modo são caracterizadas as formas de aprendizado a partir das relações entre as empresas de máquinas e os seus usuários da cadeia de calçados e os efeitos dessas interações para a organização e o desenvolvimento das empresas de bens de capital.

Para realizar esse levantamento, a pesquisa contou com duas estratégias complementares, a análise de informações secundárias e a realização de uma pesquisa empírica junto aos produtores de máquinas.

As empresas de bens de capital para calçados são caracterizadas pela variedade tecnológica de produtos fabricados sob encomenda e pela flexibilidade no atendimento de diferentes tipos de usuários com distintas especializações produtivas. Adicionalmente, os fluxos de informação com os usuários, produtores de calçados, têm contribuído para o desenvolvimento tecnológico das máquinas. Todavia, percebe-se que os segmentos fabricantes de máquinas customizadas apresentam uma tendência a acumular, relativamente, mais competências tecnológicas que as empresas de máquinas commoditizadas.

O resultado mostra que o processo de aprendizado resultante das interações entre produtores de máquinas e seus usuários pode variar em função das características competitivas dos segmentos de máquinas, das estruturas de oferta e das flutuações no ambiente macroeconômico. Além disso, fica claro que os sistemas locais de produção exercem importante papel ao acentuar as formas de articulação local e a integração entre os sistemas de produção e de conhecimento, contribuindo para o desenvolvimento de capacitações internas às empresas de máquinas.

Palavras-chave: SLPs, Clusters, Indústria de bens de capital, Aprendizagem tecnológica. 


\section{ABSTRACT}

This master dissertation focuses on the competitiveness of the capital goods producers, by looking at the user-producer interaction in the two main Local Productive Systems of footwear in Brazil, the Sinos Valley (RS) and Franca (SP). By this way, it is characterized the modes of learning generated by the interaction between machinery firms and its users of the footwear chain and its effects for the capital goods producers.

To do this, there were two different research strategies, the analysis of secondary data, and a empirical survey with capital goods producers.

The footwear capital goods producers present a great technological diversity of outputs manufactured under order and flexibility in the attendance of different types of users, with different productive specialization. Additionally, the information flows with their users, the footwear producers, have contributed to the technological development of the capital goods. However, it could be seen that the segment of customized manufacturers of machines presents a trend to accumulate relatively more capabilities.

The main results show that the learning process that comes from the interaction between machinery producers and their users can vary in function of the competitive characteristics of the capital goods segments, of the supply structure and the macroeconomic fluctuations. So, it's clear that the Local Production Systems plays an important role in fostering the local linkages among manufacturing and knowledge systems, in order to improve of he technological capabilities of Brazilian machinery producers.

Key words: SLPs, Clusters, industry of capital good, technological learning. 


\section{LISTA DE ILUSTRAÇÕES}

Figura 1 - Encadeamentos tecnológicos em diferentes categorias de firmas ........... 23

Figura 2 - Componentes da geração de conhecimentos interno à empresa ............. 55

Figura 3 - Sistema de conhecimento de empresas organizadas em clusters ........... 65

Figura 4 - Evolução do Índice de Crescimento do PIB e da FBKF............................ 88

Figura 5 - Segmentos da cadeia de calçados e sua integração com outros ramos

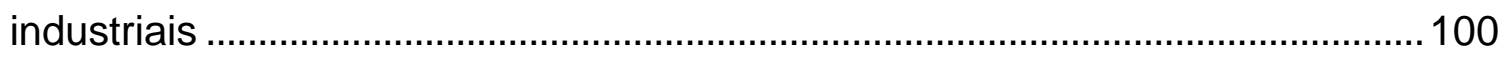

Figura 6 - Localização da região do Vale do Rio do Sinos. ........................................142

Figura 7 - Localização da cidade de Franca.............................................................143 


\section{LISTA DE QUADROS}

Quadro 1 - Padrão setorial e tecnológico de Pavitt (1984) …………………….........24

Quadro 2 - Modos de conversão do conhecimento ………………………………... 47

Quadro 3 - Mudança técnica e a relevância da proximidade geográfica nas relações

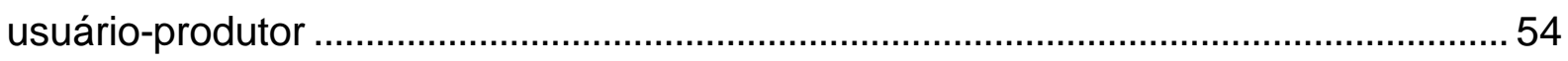

Quadro 4 - Características das relações horizontais e verticais em SLPs................. 73

Quadro 5 - Etapas da produção de calçados ............................................................ 102

Quadro 6 - Parcerias entre algumas empresas nacionais de máquinas e os concorrentes do mercado externo. ............................................................................119

Quadro 7 - Tecnologias e máquinas utilizadas na produção de calçados (por etapa)

Quadro 8 - Participação de empresas nacionais de máquinas para calçados em feiras internacionais (selecionadas) .....................................................................130

Quadro 9 - Fontes de consulta setoriais utilizadas na pesquisa empírica ................136

Quadro 10 - Critérios de definição da amostra de empresas de máquinas para

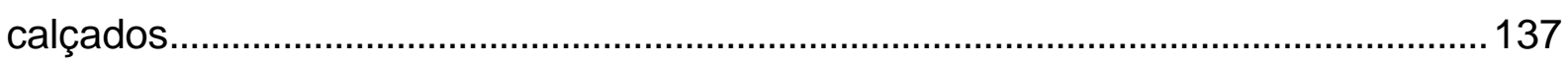

Quadro 11 - Questões analíticas e construtos da pesquisa empírica........................140

Quadro 12 - Amostra de empresas de máquinas para calçados..............................144

Quadro 13 - Características do regime tecnológico em empresas de máquinas para

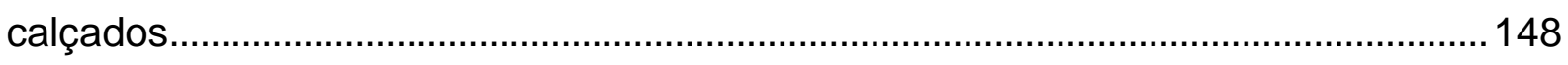

Quadro 14 - Parâmetros utilizados na caracterização dos processos de aprendizagem em empresas de máquinas para calçados....................................... 152

Quadro 15 - Características do aprendizado interno às empresas de máquinas para calçados.

Quadro 16 - Características do aprendizado a partir de fontes externas às empresas de máquinas para calçados.

Quadro 17 - Melhorias em produtos e processos a partir das interações entre empresas de máquinas e seus usuários do setor de calçados. 


\section{LISTA DE TABELAS}

Tabela 1 - Indicadores de desempenho do setor de máquinas e equipamentos mecânicos. 78

Tabela 2 - Produto Interno Bruto e Formação Bruta de Capital Fixo. .88

Tabela 3 - Evolução do comércio brasileiro de bens de capital mecânicos. .89

Tabela 4 - Exportações de máquinas e equipamentos da China. 91

Tabela 5 - Importações de máquinas e equipamentos da China. .92

Tabela 6 - Principais segmentos exportadores de máquinas da China 92 Tabela 7 - Número de funcionários nos principais Estados com produção de calçados do Brasil. 98

Tabela 8 - Número de empresas nos principais Estados com produção de calçados do Brasil. 99

Tabela 9 - Evolução dos materiais utilizados na fabricação de calçados. 106

Tabela 10 - Produção e consumo interno da indústria de calçados do Brasil. 112

Tabela 11 - Principais países produtores de calçados no mundo. 112

Tabela 12 - Principais países consumidores de calçados no mundo. 113

Tabela 13 - Principais países exportadores de calçados no mundo.

Tabela 14 - Exportações brasileiras de calçados, por países de destino 114

Tabela 15 - Número de empresas e de funcionários do setor de máquinas para couro e calçados.

Tabela 16 - Evolução das exportações brasileiras de máquinas para couro e calçados.

Tabela 17 - Número de empresas brasileiras exportadoras de máquinas para calçados. 132

Tabela 18 - Exportação e importação chinesa de máquinas para couro 133 


\section{SUMÁRIO}

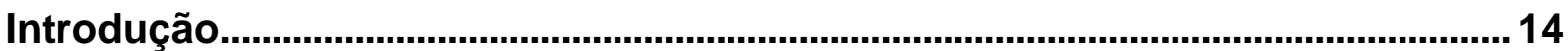

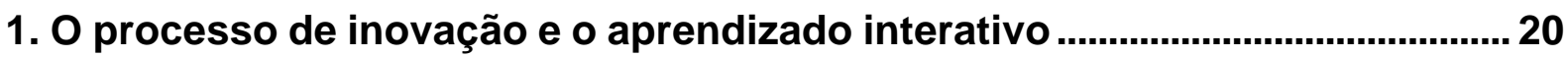

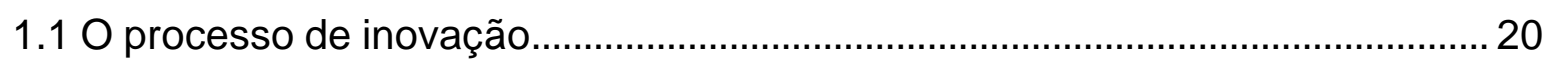

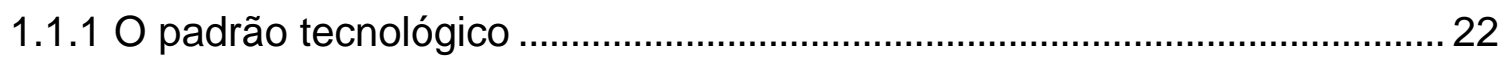

1.1.2 Sistema Nacional de Inovação ………………………………………......2

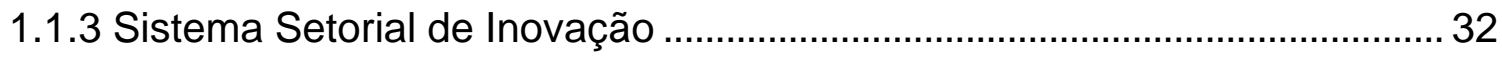

1.1.4 Elementos da vantagem competitiva ......................................................... 34

$1.2 \mathrm{O}$ aprendizado inovativo e a mudança técnica .................................................... 36

1.2.1 A Capacidade de absorção e o Aprendizado Organizacional ..................... 40

1.2.2 $\mathrm{O}$ aprendizado das relações usuário-produtor ............................................51

1.3 Considerações sobre o processo de inovação e o aprendizado inovativo ........57

2. A contribuição dos SLPs para as atividades inovativas ..................................60

2.1 As características estruturais e o caráter inovativo dos SLPs ...........................61

2.2 A proximidade geográfica nos SLPs e o processo de aprendizado interativo 68

3. A indústria de bens de capital no Brasil ...........................................................76

3.1 A organização industrial e produtiva da indústria de bens de capital................ 77

3.2 Panorama da indústria brasileira de bens de capital ......................................... 83

3.3. O desenvolvimento de capacidades e tecnologias em bens de capital...........94

4. A indústria de máquinas para couro e calçados no Brasil ...............................98

4.1 A indústria de calçados: desenvolvimento industrial e tecnológico ................... 98

4.1.1 O desenvolvimento de competências e tecnologias no setor de calçados

4.1.2 O desempenho da indústria de calçados no mercado externo .................112

4.2. O setor de máquinas para couro e calçados …………………………….......115

4.2.1 Desenvolvimento tecnológico das máquinas para calçados .....................123

4.2.2 As mudanças no mercado internacional de máquinas para calçados .....127

5. Procedimentos metodológicos

5.1 Questões analíticas e questionários aplicados na pesquisa empírica .............138

6. A dinâmica industrial de empresas de máquinas para calçados ..................142

6.1 O regime tecnológico do setor de máquinas para calçados ............................148

6.2 As características das fontes de aprendizado .................................................151 
6.3 As relações com os usuários da indústria de calçados 161

6.4 Características do aprendizado inovativo nas relações usuário-produtor ......166 6.5 Fatores que interferem na capacidade de absorção de conhecimentos a partir das relações com os usuários da indústria de calçados 171

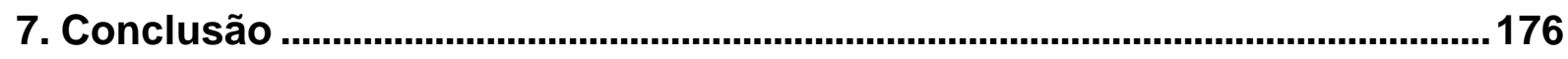

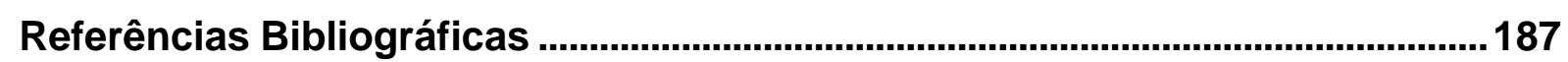

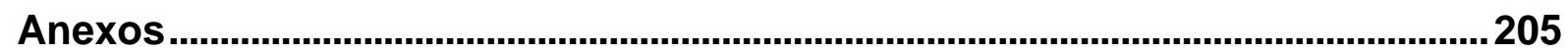




\section{Introdução}

Este trabalho analisa as relações usuário-produtor no sistema local de produção (SLP) de calçados do Brasil. Seu objetivo, portanto é caracterizar os fluxos de informação e o aprendizado decorrente das relações usuário-produtor em empresas de máquinas presentes em dois principais sistemas locais de produção (SLPs) de calçados, considerando os efeitos dessas relações para a organização interna e o desenvolvimento de novas capacitações nas empresas de máquinas.

Nas últimas décadas, as atividades inovativas realizadas por empresas e setores têm acentuado as condições para desenvolver novos atributos e têm possibilitado a incorporação e difusão de competências em produtos e processos ao longo das cadeias.

O principal aspecto dessas atividades é que elas interferem na trajetória tecnológica que a empresa dominará no longo prazo e no seu desenvolvimento industrial, contribuindo para a manutenção de vantagens competitivas duradouras dos setores industriais.

Adicionalmente, as atividades inovativas têm uma característica descontínua e irregular que é explicada pelo regime tecnológico de cada setor: as propriedades das tecnologias e os caminhos escolhidos para incorporar conhecimentos ao longo das cadeias interferem no seu padrão de mudanças técnicas no longo prazo.

De um lado, as tecnologias apresentam diferentes condições de oportunidade e de apropriação; graus distintos de cumulatividade e determinam variações nas características dos conhecimentos-base internos às empresas, que podem reforçar ou alterar a trajetória adotada pelas empresas no longo prazo, seja em inovações de produtos ou de processos. De outro lado, o modo como as informações são difundidas e incorporadas no ambiente interno e externo às empresas, por sua vez, representam formas e instrumentos relevantes para realizar melhorias e refletem nas habilidades implícitas no sistema de inovação de cada país, setor e nas empresas.

A noção de Sistema Nacional de Inovação incorpora não só as características das tecnologias e a variedade de mecanismos para a sua difusão e incorporação, mas destaca que as relações sociais e as estruturas de governança voltadas ao 
aprendizado também contribuem significativamente para o domínio tecnológico do setor. Isto porque o sistema é constituído por um fluxo dinâmico entre os subsistemas de produção e de conhecimento, com diferenças em termos de experiências históricas, culturais e de linguagem, que determinam idiossincrasias na organização interna das empresas e na sua relação com outros agentes.

Desse modo, a partir das relações sociais, os sistemas de produção e de conhecimento podem desenvolver uma multiplicidade de mecanismos voltados à acumulação de estoques de informações e habilidades que se refletem na direção da mudança técnica e na trajetória tecnológica dos setores industriais.

A característica cumulativa das informações tecnológicas facilita a organização dos vários modos de aprendizado interno e externo às empresas que têm dois efeitos para desenvolvimento econômico e inovativo: o aprendizado não só leva à acumulação de capacidades internas às empresas, mas determina o aumento da capacidade para aprender sobre novos produtos e processos e responder às mudanças nas circunstâncias do mercado. Além disso, o aprendizado interativo interfere na organização interna das empresas, em especial, em sua habilidade para reconhecer o valor de uma nova informação externa, assimilá-la e aplicá-la para fins comerciais.

A literatura tem apresentado inúmeros formatos de relações como as parcerias, joint ventures, interações verticais e relações horizontais direcionadas ao aprendizado e aos ganhos econômicos ao longo das cadeias industriais.

As parcerias na distribuição e comercialização de um mesmo produto e as joint ventures estabelecidas entre empresas para a fabricação de um mesmo produto, por exemplo, possibilitam a exploração de novas oportunidades técnicas e comerciais e o aprendizado de processos e produtos. Entretanto, esses processos, freqüentemente, não são vantajosos para a formação de competências dinâmicas e a capacidade para a absorção de novos atributos competitivos de todos os participantes envolvidos nos acordos, principalmente quando o objetivo do acordo é estritamente a inserção comercial em novos mercados.

As relações verticais do tipo usuário-produtor, por outro lado, podem interferir na interdependência tecnológica existente nas unidades usuárias e produtoras, porque a partir do aprendizado interativo, as empresas produtoras ampliam o estoque de informações especializadas. Nesse sentido, as interações permitem o desenvolvimento de novas habilidades, melhorias em produtos e/ou rupturas em 
padrões pré-estabelecidos nas unidades usuárias e produtoras, refletindo na difusão de melhorias para outros segmentos industriais. Entretanto, a dinâmica das relações usuário-produtor também apresenta aspectos como as características das tecnologias e as especificidades da dimensão econômica e social das interações que desencadeiam elevado grau de incerteza e irregularidade nas relações verticais, restringindo o processo de inovação.

Nas últimas décadas, os sistemas locais de produção (SLPs) têm contribuído significativamente para amenizar essas dificuldades na realização de inovações e na trajetória tecnológica das empresas e setores industriais, em especial entre as empresas de pequeno porte, porque a aglomeração espacial de empresas e instituições acentua as complementaridades tecnológicas a partir do adensamento das relações ao longo da cadeia.

Os sistemas locais de produção podem ajudar no desenvolvimento industrial, principalmente, de duas maneiras: de um lado, as economias externas incidentais, resultado da formação histórica e cultural dos agentes de etapas a jusante e a montante, caracterizam a presença de funcionários capacitados e de ambiente propício à troca de informações sobre produtos e processo no sistema. De outro lado, as ações conjuntas deliberadas entre os agentes e os segmentos da cadeia, reforçadas pela proximidade geográfica e identidade cultural no interior do SLP, permitem a incorporação de novos atributos e a sustentação de benefícios econômicos para o conjunto de empresas e instituições.

Entretanto, a mera existência de aglomerações espaciais de empresas não é um fator suficiente para explicar o dinamismo tecnológico dos SLPS. É a forma como as informações são incorporadas e difundidas nesses sistemas que reflete em níveis distintos de criação de competências dinâmicas e no desempenho das empresas ao longo das cadeias.

No sistema local de produção de calçados, a proximidade geográfica e as relações estabelecidas entre os segmentos, em especial entre as empresas de máquinas e os seus usuários do segmento de calçados, são responsáveis por significativas melhorias nas capacidades desenvolvidas no interior das empresas e do setor.

É importante considerar que, do lado das empresas de calçados, a variedade dos produtos, os requerimentos tecnológicos distintos e a sazonalidade da demanda determinaram o desenvolvimento de empresas com portes e capacitações distintas, 
que imprimem elevado dinamismo às redes de relacionamentos com outras empresas e segmentos da cadeia calçadista.

De outro lado, as estruturas de produção e de oferta da indústria de bens de capital, assim como a políticas macroeconômicas adotadas ras últimas décadas, têm determinado uma diversidade de situações e padrões de concorrência que refletem diretamente na relação entre os fornecedores de máquinas e as empresas de calçados e no potencial inovativo dos SLPs de calçados.

As flutuações da demanda numa dimensão relativamente maior do que nos outros setores, em função do contexto macroeconômico e de seus efeitos sobre o nível geral de investimentos da economia, refletem no comportamento pró-cíclico e no dinamismo dos segmentos de máquinas. Nas empresas de máquinas com atuação em SLPs de setores tradicionais como calçados, o comportamento prócíclico interfere, principalmente, no dimensionamento da produção. Entretanto, a criação de competências e o aprendizado inovativo dessas empresas de máquinas, por sua vez, estão atrelados às capacidades internas aos SLPs.

Nas últimas décadas, as alterações da política econômica interferiram no desempenho das empresas nacionais de calçados e determinaram mudanças significativas como a reestruturação industrial e produtiva e o desenvolvimento (ou fortalecimento) de atributos comerciais e tecnológicos do setor.

A participação de outros países na produção mundial de calçados também tem modificado a organização e o desempenho das empresas brasileiras do SLP de calçados no mercado interno e externo. No segmento de máquinas para calçados do Brasil, por exemplo, o crescimento da participação de produtores asiáticos resultou, principalmente, no adensamento das interações entre empresas - inclusive com outros segmentos e empresas de outros países -, na intensificação das estratégias comerciais e na atualização tecnológica visando 0 aprendizado tecnológico e o desenvolvimento e/ou fortalecimento de outros atributos competitivos.

A pesquisa empírica realizada junto a nove empresas com produção de máquinas e quatro empresas de calçados dos dois SLPs - Vale do Sinos (RS) e na cidade de Franca (SP) - apresenta as características principais das interações entre produtores e usuários de máquinas e as contribuições desses vínculos para a melhoria de produtos e o desenvolvimento das empresas de máquinas para calçados. 
De maneira geral, as interações usuário-produtor têm acentuado o desenvolvimento das empresas de máquinas dos dois sistemas locais, mas os efeitos sobre a estrutura industrial são distintos entre os segmentos de máquinas para calçados. Em grande medida, a participação das empresas produtoras e usuárias de máquinas em sistemas locais mais (ou menos) dinâmicos e a estrutura de produção e de oferta do usuário determinam diferenças na interação com fontes externas de informação e na dinâmica de aprendizado e de desenvolvimento de produtos entre as empresas de máquinas para calçados.

O trabalho está dividido em sete capítulos.

O primeiro capítulo apresenta as principais contribuições da literatura sobre inovação e aprendizado interativo. Esse capítulo foi dividido em duas seções: a primeira discute as características do conhecimento e do processo inovativo; enquanto a segunda seção apresenta os mecanismos de aprendizado interno e externo às empresas e verifica de que maneira essas fontes de informação podem contribuir para o aprendizado organizacional e para a criação de competências dinâmicas.

O segundo capítulo discute as características estruturais dos SLPs que possibilitam a integração entre o sistema de produção e de conhecimento no interior da aglomeração espacial de empresas. Adicionalmente, o capítulo examina como os sistemas locais podem acentuar o desenvolvimento industrial e o aprendizado inovativo de toda a cadeia.

O terceiro capítulo tem por objetivo apresentar o panorama da indústria de bens de capital do Brasil, considerando três aspectos: sua organização industrial e produtiva; os fatores responsáveis pelo desenvolvimento nas últimas décadas; e os mecanismos para a criação e difusão de competências da indústria de máquinas.

O quarto capítulo examina o desenvolvimento industrial e tecnológico da indústria de calçados e do setor de máquinas para calçados em duas seções. A primeira seção discute brevemente o setor de calçados, apresentando as características de sua dinâmica produtiva; os principais aspectos de desenvolvimento tecnológico e da criação de competências; e as modificações no desempenho do setor de calçados em virtude da participação de produtores de calçados do mercado externo. A segunda seção do capítulo, por sua vez, discute as características do setor de máquinas para calçados, considerando três aspectos: o seu desenvolvimento industrial e tecnológico; as estratégias de atualização 
tecnológica adotada na última década; e as alterações no desempenho dos segmentos por conta da entrada de empresas fabricantes de máquinas de outros países.

O quinto capítulo discorre sobre os procedimentos metodológicos para a análise empírica das relações usuário-produtor nos SLPs de Franca (SP) e do Vale do Sinos (RS). O capítulo destaca as fontes de informação setorial utilizadas na caracterização dos segmentos de máquinas e de calçados, os critérios definidos para a elaboração de uma amostra de máquinas para calçados; e os procedimentos adotados na elaboração dos questionários aplicados em empresas e instituições do setor.

O sexto capítulo apresenta os resultados da pesquisa empírica realizada junto às empresas de máquinas e de calçados dos dois SLPs. O objetivo do capítulo é discutir as características do regime tecnológico e do aprendizado interativo interno e externo às empresas de máquinas considerando, principalmente, como os fluxos de informação a partir de interações com os usuários da cadeia de calçados têm refletido na dinâmica industrial e no desenvolvimento inovativo de empresas de máquinas para calçados. Adicionalmente, o capítulo identifica os fatores que do ponto de vista dos usuários, têm determinado alterações no aprendizado inovativo e na melhoria de produtos e processos ao longo da cadeia de calçados.

O sétimo capítulo traz as conclusões da dissertação. 


\section{O processo de inovação e o aprendizado interativo}

$\mathrm{Na}$ última década, um conjunto crescente de estudos tem ressaltado a necessidade de alavancar e incorporar conhecimentos e melhorias em produtos e processos à estratégia competitiva das empresas.

Malerba e Orsenigo (1997, p. 83-84) ressaltam que a evolução industrial pode ser caracterizada por notáveis graus de persistência nas atividades inovativas de um número considerável de empresas e que as turbulências nessas atividades também são o motor do processo de inovação.

A compreensão sobre esse fenômeno é importante para o tecido industrial porque $o$ lançamento de novos produtos e, principalmente, as formas de organização da produção e de atividades afins, se refletem no amadurecimento tecnológico que pode alavancar o desempenho econômico das empresas.

A capacidade para desenvolver essas formas de aprendizado inovativo, por sua vez, está relacionada às possibilidades de transferência de informação e de conhecimento e às especificidades da dinâmica da inovação que é condicionada pelo regime tecnológico (CAMPOS et al, 2003, p. 53). Se por um lado essas duas perspectivas - formas de aprendizado e o regime tecnológico - estão entrelaçados, há também outros aspectos implícitos do sistema nacional de inovação, do sistema setorial e do ambiente interno das empresas, que podem repercutir no processo de inovação e no desempenho desses atores.

\subsection{0 processo de inovação}

A inovação tem assumido papel cada vez mais importante nas estratégias de empresas de portes distintos, que vêem esse fator como central para a sua competitividade.

As contribuições da literatura mudaram o entendimento sobre o caráter linear e exógeno do processo inovativo, proposto pela Economia tradicional, e ampliaram o leque de atividades consideradas como inovativas. Schumpeter (1984, p. 107) 
ressalta que a concorrência de novas mercadorias, novas técnicas, novas fontes de suprimento e novos tipos de organização têm forte papel sobre a base de sustentação das empresas, inaugurando uma corrente de estudos que considera a as atividades inovativas como fenômeno intrínseco ao desenvolvimento econômico.

Nesse contexto, um conjunto de conceitos foi desenvolvido com o objetivo de fundamentar e explicar as diferenças intra-setoriais no crescimento da produtividade e no desenvolvimento tecnológico nas últimas décadas.

A inovação pode ser definida como "conjunto de busca, descoberta, experimentação, imitação e adoção de novos produtos, novos processos e novas técnicas organizacionais", que dependem não apenas de atividades de P\&D como também da experiência adquirida e acumulada pelas pessoas e organizações (ROVERE, 2006, p. 287).

Recentemente, a inovação também tem sido destacada como processo que pode ocorrer em diferentes etapas desde a obtenção de um produto até o seu lançamento no mercado e, nesse processo, as empresas dominam e implementam novos projetos e produção de bens e serviços para elas, mesmo que não o sejam para os seus concorrentes (LEMOS, 2000; CASSIOLATO; LASTRES, 2001, p. 249).

Outro aspecto importante é que a inovação compreende não apenas mudanças na tecnologia de produto, mas novas formas de organização e gestão de produção que não obtidas exclusivamente a partir da pesquisa realizada em laboratórios de P\&D (CASSIOLATO e LASTRES, 2001, p. 249; LEMOS, 2000, p. 161) e da interação com outras empresas e instituições.

Nesse cenário, as atividades inovativas têm condições de transformar o mecanismo de mercado, como as práticas que visam à conservação de posições tradicionais e à exploração dos lucros em que as posições se baseiam. E podem contribuir, a partir da 'destruição criadora', para atenuar as dificuldades temporárias enfrentadas pelas empresas (SCHUMPETER, 1984).

Cabe ressaltar que a característica descontínua e irregular do processo de inovação influencia diferentemente os setores industriais, por meio de saltos do paradigma tecnológico realizados em determinados períodos do tempo.

O paradigma tecnológico é definido como um conjunto de conhecimentos articulados e derivados do conhecimento científico e das experiências e habilidades produtivas, voltadas às soluções de problemas de ordem técnica (DOSI, 1982, p. 152; VERMULM, 1998, p. 6). 
A especificidade dos problemas gera diferentes escolhas de ordem técnica e econômica entre as possíveis alternativas de desenvolvimento tecnológico vislumbradas pelas empresas, de acordo com as características do setor e do ambiente institucional em que elas atuam (ROVERE, 2006, p. 288). Entretanto, enquanto o conceito de paradigma tecnológico enfatiza a geração e adoção de inovações, o conceito de trajetória tecnológica refere-se à difusão de inovações e às mudanças entre as escolhas técnicas e produtivas realizadas pelas empresas $\mathrm{e}$ setores.

As escolhas realizadas pelas empresas dentro de um arcabouço técnicoprodutivo conformam as suas trajetórias tecnológicas. Mas como um paradigma admite mais de uma alternativa, existe um grau de incerteza sobre o sucesso técnico da atividade no longo prazo (ROVERE, 2006, p. 288; VERMULM, 1998).

Outro fator relevante é que também a descontinuidade das atividades inovativas determina o grau de incerteza na atuação das empresas e em sua capacidade de realizar avanços, interferindo em sua trajetória tecnológica. Essa capacidade inovativa, por sua vez, também é influenciada pelas características das tecnologias que estão sendo utilizadas e pela experiência acumulada ao longo dos anos (DOSI, 1988; LEMOS, 2000, p. 160).

O ambiente econômico e social pode funcionar como mecanismo de seleção da alternativa mais rentável, que acaba por se constituir na trajetória tecnológica de um paradigma. E dessa forma, o paradigma tecnológico delimita as possibilidades de mudança técnica para a empresa (VERMULM, 1998, p. 7).

Nas seções seguintes são apresentadas as principais contribuições da literatura sobre as características do conhecimento inovativo e do aprendizado vislumbrados pelas empresas para melhorar seu desempenho nas economias industriais recentes.

\subsubsection{O padrão tecnológico}

Os comportamentos das empresas e das instituições desencadearam e continuam promovendo mudanças nas formas de organização setorial, resultando em maior dinamismo do tecido industrial. Os estudos empíricos sobre o padrão 
setorial e tecnológico têm contribuído para essa análise sobre o desempenho dessas empresas, ao considerar que a heterogeneidade setorial e os graus distintos do patamar tecnológico podem alavancar ou restringir o cenário de atuação desses agentes.

Em sua taxonomia sobre a produção e difusão de inovações, Pavitt (1984) ressalta que a atividade principal da empresa influencia a sua trajetória tecnológica entendida como a direção tomada pelo desenvolvimento tecnológico, dada as escolhas constantes do paradigma - e, dessa forma, interfere nos níveis de geração, incorporação e difusão de inovações (NELSON; WINTER, 1977; PAVITT, 1984).

Os encadeamentos tecnológicos dessas empresas nas economias industriais extrapolam as meras transações de compra e venda de bens, podendo incluir também fluxos de informações e patamares distintos de habilidades. Nesse contexto, segundo o autor, a indústria produz a maioria das inovações que são usadas em outras partes da economia, mas está longe de ser homogênea em padrões de produção e uso de inovações.

De acordo com a tipologia de Pavitt (1984), as empresas 'dominadas por fornecedores' e 'intensivas em escala' adquirem as inovações através da compra de máquinas e de empresas de engenharia, enquanto as empresas participantes dos setores 'baseados em ciência' criam as inovações demandadas por outros setores (figura 1).

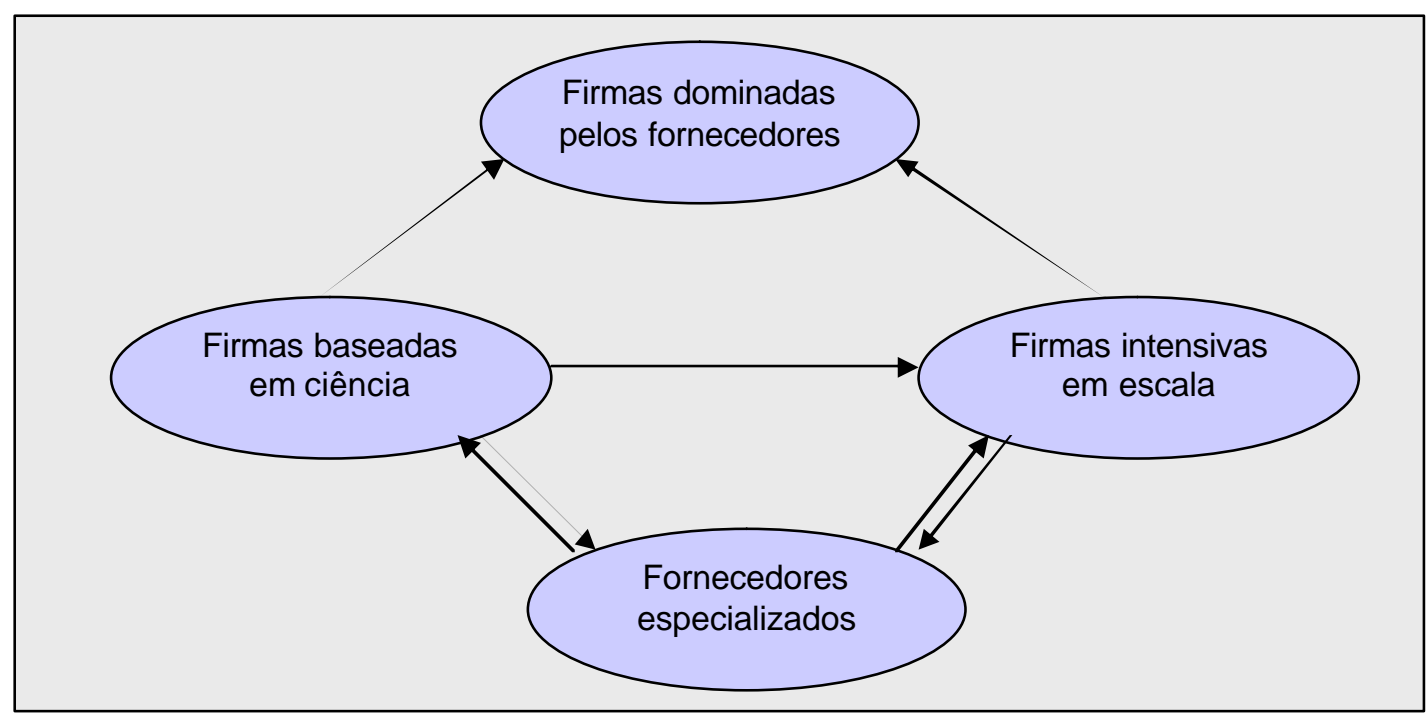

Fonte: Pavitt, 1984.

Figura 1 - Encadeamentos tecnológicos em diferentes categorias de firmas

O padrão tecnológico pode imprimir características específicas aos grupos 
de empresas de ramos de atividades diferentes e é responsável pelo amadurecimento tecnológico e pela direção da inovação estabelecida nos setores industriais uma vez que as fontes de tecnologia, os tipos de usuários e os mecanismos de apropriação são distintos entre um grupo e o outro, como pode ser verificado no Quadro 1 a seguir.

\begin{tabular}{|c|c|c|c|c|c|}
\hline \multirow{3}{*}{\multicolumn{2}{|c|}{$\begin{array}{c}\text { Características principais das } \\
\text { categorias }\end{array}$}} & \multicolumn{4}{|c|}{ Categorias da firma } \\
\hline & & \multirow{2}{*}{$\begin{array}{l}\text { Dominada } \\
\text { pelo } \\
\text { fornecedor }\end{array}$} & \multicolumn{2}{|c|}{ Intensiva em produção } & \multirow{2}{*}{$\begin{array}{l}\text { Baseada em } \\
\text { ciência }\end{array}$} \\
\hline & & & $\begin{array}{c}\text { Intensiva em } \\
\text { escala }\end{array}$ & \begin{tabular}{|c|} 
Fornecedores \\
especializados
\end{tabular} & \\
\hline Atividades nucl & leares típicas & $\begin{array}{l}\text { Agricultura, } \\
\text { construção } \\
\text { civil, serviços } \\
\text { privados, } \\
\text { manufatura } \\
\text { tradicional. }\end{array}$ & \begin{tabular}{|c|} 
Materiais \\
volumosos (Aço, \\
Vidro); montagem \\
(bens de consumo \\
duráveis e autos).
\end{tabular} & $\begin{array}{l}\text { Maquinaria; } \\
\text { instrumentos de } \\
\text { precisão. }\end{array}$ & $\begin{array}{l}\text { Eletrônico/ } \\
\text { elétrico; } \\
\text { Químico. }\end{array}$ \\
\hline \multirow{3}{*}{$\begin{array}{l}\text { Fatores } \\
\text { determinantes } \\
\text { das atividades } \\
\text { tecnológicas }\end{array}$} & $\begin{array}{l}\text { Fontes de } \\
\text { tecnologia }\end{array}$ & $\begin{array}{l}\text { Extensão dos } \\
\text { serviços de } \\
\text { pesquisa dos } \\
\text { fornecedores. }\end{array}$ & $\begin{array}{l}\text { Engenharia de } \\
\text { produção dos } \\
\text { fornecedores. }\end{array}$ & $\begin{array}{c}\text { Projeto e } \\
\text { desenvolvimento } \\
\text { pelos usuários. }\end{array}$ & $\begin{array}{c}\text { P\&D; ciência } \\
\text { pública; } \\
\text { Engenharia de } \\
\text { produção. } \\
\end{array}$ \\
\hline & $\begin{array}{l}\text { Tipos de } \\
\text { usuários }\end{array}$ & $\begin{array}{c}\text { Sensível ao } \\
\text { preço }\end{array}$ & Sensível ao preço & $\begin{array}{l}\text { Sensível ao } \\
\text { desempenho }\end{array}$ & Misto \\
\hline & $\begin{array}{c}\text { Mecanismos } \\
\text { de } \\
\text { apropriação }\end{array}$ & $\begin{array}{l}\text { Não-técnico } \\
\text { (marcas, } \\
\text { marketing, } \\
\text { propaganda, } \\
\text { aparência } \\
\text { estética). }\end{array}$ & $\begin{array}{c}\text { Segredo e know- } \\
\text { how de processo; } \\
\text { defasagens } \\
\text { técnicas; patentes; } \\
\text { economias } \\
\text { dinâmicas de } \\
\text { aprendizado. }\end{array}$ & $\begin{array}{l}\text { Know-how de } \\
\text { projeto; } \\
\text { conhecimento } \\
\text { dos usuários; } \\
\text { patentes. }\end{array}$ & \begin{tabular}{|c} 
Know-how de \\
P\&D; patentes; \\
segredo e \\
know-how de \\
processo; \\
economias \\
dinâmicas de \\
aprendizado.
\end{tabular} \\
\hline \multicolumn{2}{|c|}{ Trajetórias tecnológicas } & $\begin{array}{l}\text { Redução de } \\
\text { custos }\end{array}$ & \begin{tabular}{|c|}
$\begin{array}{c}\text { Redução de custos } \\
\text { (no projeto do } \\
\text { produto) }\end{array}$ \\
\end{tabular} & $\begin{array}{l}\text { Projeto de } \\
\text { produto }\end{array}$ & Mista \\
\hline \multirow{4}{*}{$\begin{array}{l}\text { Característica } \\
\text { s mensuradas }\end{array}$} & $\begin{array}{l}\text { Fontes de } \\
\text { tecnologia }\end{array}$ & Fornecedores & $\begin{array}{c}\text { Interna; } \\
\text { Fornecedores. }\end{array}$ & $\begin{array}{l}\text { Interna; } \\
\text { Clientes. }\end{array}$ & $\begin{array}{c}\text { Interna; } \\
\text { Fornecedores. }\end{array}$ \\
\hline & \begin{tabular}{|c|} 
Inovação \\
relativamente \\
predominante
\end{tabular} & Processo & Processo & Produto & Mista \\
\hline & $\begin{array}{c}\text { Tamanho } \\
\text { relativo das } \\
\text { firmas } \\
\text { inovadoras }\end{array}$ & Pequeno & Grande & Pequeno & Grande \\
\hline & $\begin{array}{c}\text { Intensidade e } \\
\text { direção da } \\
\text { diversificação } \\
\text { tecnológica }\end{array}$ & $\begin{array}{l}\text { Baixa; } \\
\text { vertical. }\end{array}$ & $\begin{array}{l}\text { Alta; } \\
\text { vertical. }\end{array}$ & $\begin{array}{c}\text { Baixa; } \\
\text { concêntrica. }\end{array}$ & $\begin{array}{l}\text { Baixa, vertical } \\
\text { /Alta, } \\
\text { concêntrica. }\end{array}$ \\
\hline
\end{tabular}

Fonte: Pavitt (1984).

Quadro 1 - Padrão setorial e tecnológico de Pavitt (1984).

$\mathrm{Na}$ primeira categoria, empresas como as da indústria têxtil utilizam as melhorias incorporadas através dos contatos com os fornecedores de insumos e de 
máquinas e equipamentos como principal fonte de inovação.

As empresas "intensivas em produção", por sua vez, caracterizam-se pela forte participação dos usuários e dos departamentos de engenharia no processo inovativo. Esse grupo de empresas intensivas em produção foi subdividido em duas classes - intensivas em escala e fornecedores especializados, de acordo com as suas atividades nucleares típicas. No primeiro, as empresas trabalham com grandes volumes e a fonte principal de inovação tecnológica de processo é desenvolvida pelos fornecedores. As empresas do segundo grupo, por sua vez, incorporam inovações de produto a partir de pesquisas realizadas entre os usuários.

Por fim, as empresas "baseadas em ciência" dos setores químico e eletrônico, diferentemente das demais categorias, estabelecem escritórios de P\&D e parcerias com unidades de pesquisa como principal fonte de atividade inovativa.

Cabe ressaltar que há dois aspectos relevantes do padrão tecnológico que ajudam a entender as estratégias inovativas das empresas dominadas por fornecedores. Primeiramente, a inovação nessas empresas depende fortemente das relações verticais estabelecidas com outros agentes da cadeia. Segundo, uma vez que elas adquirem inovações de produto fora de seu setor de atuação, a inovação depende também da qualidade dessa demanda (PAVITT, 1984; EDQUIST; HOMMEN, 1999).

Esse último fator tem impacto significativo na incorporação de novas tecnologias ou em mudanças incrementais realizadas pelas empresas. A qualidade da demanda pode ser caracterizada pelo patamar de desenvolvimento técnico e tecnológico dos setores consumidores, principalmente aqueles adjacentes ao setor produtor, e pelas condições que essas empresas usuárias detêm para incorporar as melhorias ao seu ambiente fabril.

Além disso, há peculiaridades no lado da demanda, como a qualificação de mão-de-obra na unidade de produção, que interferem no desenvolvimento e na estrutura inovativa de maneira distinta de um setor para outro. Por isto mesmo, o caráter inovativo de produtores e usuários pode diferir relativamente dos patamares encontrados nos mesmos setores localizados em outros países ${ }^{1}$.

Nesse sentido, as características da fonte de tecnologia utilizada em cada

\footnotetext{
${ }^{1} \mathrm{Em}$ setores tradicionais, a qualidade dessa demanda diz respeito também às condições mais adequadas à criação de laços entre os usuários e os produtores de tecnologias emergentes, e está sob forte influência das políticas públicas e privadas (EDQUIST; HOMMEN, 1999).
} 
um dos grupos de empresas são responsáveis pelo seu domínio técnico e por sua capacidade para gerar melhorias em produtos ou em processos no longo prazo.

Pavitt (1984) considera que direção e a taxa de mudança das tecnologias dos setores industriais podem ser influenciadas por três aspectos:

- Fontes de tecnologia;

- Características das necessidades dos usuários; e

- Possibilidades de os inovadores bem-sucedidos apropriarem-se dos benefícios de suas atividades inovativas.

As fontes de tecnologia podem ser classificadas como internas - nos escritórios de P\&D e departamentos de engenharia - e externas às empresas fornecedores, usuários, pesquisa e consultoria com financiamento público.

As características do meio em que o conhecimento tecnológico é transmitido - a dependência de rupturas ou melhorias incrementais das fontes de conhecimento interno e externo - são aspectos que perpassam o processo de inovação ${ }^{2}$ porque refletem um conjunto de estratégias necessárias à incorporação e ao desenvolvimento de melhorias de produtos e processos.

As condições de oportunidade refletem a facilidade da inovação para uma dada soma de recursos investidos em pesquisa (MALERBA e ORSENIGO, 1997, p. 94), determinando possibilidades distintas de inovação entre as empresas, considerando que quanto maiores as condições de oportunidade de uma empresa, maiores as chances de geração de inovações.

As necessidades dos usuários variam ao longo do tempo entre aqueles setores em que o preço tem maior importância, enquanto em outros o desempenho e a confiabilidade passa a ser um atributo mais relevante do que o preço.

Os métodos usados para as empresas inovadoras apropriarem-se dos efeitos de atividades inovativas ou condições de apropriação (Nelson e Winter, 1982), por sua vez, são as possibilidades de proteger a inovação de imitações e de obter lucros a partir dessas atividades inovativas (MALERBA; ORSENIGO, 1997, p. 94). Podem ser identificadas duas dimensões das condições de apropriação:

- Nível de apropriação - se refere às condições e limitações características do

\footnotetext{
${ }^{2}$ Além dessas fontes, as condições de oportunidade também podem ser classificadas de acordo com o nível, a pervasividade e a variedade (MALERBA e ORSENIGO, 1997, p. 94).
} 
meio em que a inovação ocorre. A alta apropriação significa que há mecanismos de proteção, enquanto a baixa apropriação reflete um cenário com elevada dispersão de conhecimentos.

- Meio de apropriação - são os mecanismos de proteção das atividades inovativas, que diferem de uma indústria para outra (MALERBA; ORSENIGO, 1997, p. 95) e variam de acordo com a natureza da inovação: as inovações de processo são mantidas em segredo; as inovações de produto podem ser protegidas por defasagens técnicas de imitação; e as inovações de produto e de processo podem ser protegidas pela singularidade do conhecimento tecnológico e as qualificações existentes nas empresas inovadoras (PAVITT, 1984).

Malerba e Orsenigo (1997) avançam a análise iniciada por Pavitt (1984) e Nelson e Winter (1982) sobre o padrão tecnológico, sem considerar o comportamento distinto dos setores (baseados em ciência, dominadas por fornecedores e intensivas em produção) em cada uma das categorias de Pavitt. Para eles, o padrão específico de atividade inovativa de um setor pode ser explicado como resultado de diferentes regimes tecnológicos que estão incluídos na natureza da tecnologia e do conhecimento adquiridos ou desenvolvidos (MALERBA; ORSENIGO, 1997).

O regime tecnológico, por sua vez, é definido como uma "combinação particular de algumas propriedades da tecnologia: oportunidade e condições de apropriação; grau de cumulatividade do conhecimento tecnológico; e características da base de conhecimento" (MALERBA; ORSENIGO, 1997, p. 94), as quais fornecem a base para uma explicação da diversidade nos padrões de inovação através dos setores e tecnologias (MALERBA; ORSENIGO, 1997, p. 97-98).

A literatura ressalta outros três aspectos que podem interferir na direção das mudanças tecnológicas nos setores industriais:

- Condição de cumulatividade - ressalta que as empresas que inovam no presente estão mais aptas para inovar no futuro em tecnologias específicas e ao longo de trajetórias específicas do que as empresas que não inovam.

- Conhecimento-base - refere-se à propriedade do conhecimento sobre os quais as empresas estão baseadas. Esse conhecimento-base pode interferir em estratégias de diversificação, especialização e integração de atividades inovativas (MALERBA; ORSENIGO, 1997, p. 98).

- Característica do fluxo de informações incorporado pelas empresas - tácito ou 
codificado - também se reflete na sua trajetória tecnológica porque interfere na forma como ele será compartilhado entre as empresas.

O conhecimento tácito é aquele formado pela "cumulatividade da experiência na produção e conseqüentes inovações incrementais em produtos e processos" (CAMPOS et al, 2003, p. 52). O fluxo desse conhecimento é compartilhado em canais próprios para a transmissão das mensagens (LUNDVALL, 1988) e não é facilmente apreendido pelos agentes se as empresas atuam de maneira isolada no mercado.

O conhecimento codificado, por sua vez, é referenciado na literatura como aquele obtido a partir dos investimentos em P\&D e de pesquisas desenvolvidas por instituições de ensino público e privado e pode ser mais facilmente transferido entre os agentes da cadeia.

De maneira geral, quando ele é complexo, mas codificado e dissociável, haverá altas condições de oportunidade e apropriação, e as empresas podem desenvolver redes de relações externas com empresas de atividades complementares e especializadas. Já para o conhecimento tácito e não dissociável, as empresas podem desenvolver alianças estratégicas de longo prazo, voltadas à exploração da complementaridade e visando o compartilhamento de informações.

As condições de baixa apropriação e o alto grau de conhecimento tácito e indivisível podem favorecer estratégias direcionadas ao controle completo, à integração de etapas e ao desenvolvimento de códigos internos de comunicação (MALERBA e ORSENIGO, 1997, p. 99).

Cabe ressaltar que os regimes tecnológicos (NELSON; WINTER, 1982) incorporam as especificidades da tecnologia e do caminho escolhido para incorporar esse conhecimento e condicionam o desempenho das empresas em economias industriais, enquanto a perspectiva do padrão de produção e uso de inovações de Pavitt (1984) apresenta situações distintas quanto à aquisição, criação e uso de novos produtos e processos com recorte mais setorial. Em ambos os casos, o desempenho inovativo das empresas é limitado, principalmente, pelas características da tecnologia e das capacidades técnicas dessas empresas.

Outro aspecto importante é que as atividades inovativas apresentam especificidades intra-setoriais, mas há algumas similaridades do regime tecnológico - condições de oportunidade, apropriação, cumulatividade e o conhecimento-base (MALERBA; ORSENIGO, 1982) que podem condicionar o desempenho inovativo 
entre os países (MALERBA; ORSENIGO, 1997).

Os EUA e o Japão, por exemplo, apresentam níveis e meios de apropriação e cumulatividade que são similares para uma mesma indústria (MALERBA; ORSENIGO, 1997). Contudo, a habilidade para gerar e explorar as condições de oportunidade pode diferir de um país para outro porque está relacionada ao nível e alcance da pesquisa em universidades, à presença e efetividade de mecanismos de transmissão entre a ciência e a indústria, às ligações verticais e horizontais entre empresas locais, às interações usuário-produtor e aos tipos e níveis de esforços inovativos da empresa (MALERBA; ORSENIGO, 1997, p. 100).

Nesse sentido, a natureza do regime tecnológico interfere no patamar de atividades inovativas (MALERBA; ORSENIGO, 1997, p. 94), mas há outros aspectos implícitos no desenvolvimento das empresas que podem influenciar esse processo. De maneira geral, elas definem formas e instrumentos variados para realizar as melhorias voltadas à sua competitividade e esses mecanismos de aprendizado refletem em habilidades implícitas no sistema de inovação de cada país, setor e nas empresas.

\subsubsection{Sistema Nacional de Inovação}

O Sistema Nacional de Inovação é definido a partir da escola evolucionista que considera a empresa como o núcleo de habilidades, competências e conhecimentos tecnológicos e organizacionais (FREEMAN, 1982).

Cassiolato e Lastres (2001) consideram o Sistema de Inovação como um conjunto de instituições distintas que determinam a difusão e incorporação de tecnologias. Essas instituições são empresas, órgãos de ensino e pesquisa, de financiamento, governo, entre outros.

Além disso, o Sistema é constituído por características básicas que apresentam diferenças em termos de experiência histórica, cultural e de linguagem que se reflete em idiossincrasias na organização interna das empresas, na relação interempresas e com instituições, no papel do setor público e das políticas públicas, aparato do setor financeiro, organização de P\&D, entre outros (CASSIOLATO; LASTRES, 2001, p. 247-248). 
Lundvall (1988) desenvolveu a noção de Sistema Nacional de Inovação em dois campos: o sistema nacional de produção e o sistema de inovação, e considera que há uma forte interdependência entre as duas áreas.

A produção é um processo repetitivo, no qual as atividades são executadas rotineiramente. $O$ processo de inovação pode ser contínuo e cumulativo, mas sempre terá um elemento importante, a criatividade, em oposição à rotina característica da produção (LUNDVALL, 1988).

O fluxo entre os dois subsistemas será complexo e o sistema de informação, difícil de traduzir em termos quantitativos. A interdependência decorre, de um lado, porque o aprendizado toma lugar na esfera produtiva - como 'learning-by-doing', 'learning-by-using' ou 'learning-by-interacting' - e forma um importante insumo para o processo de produção ${ }^{3}$. Por outro lado, o processo de inovação pode reestruturar o sistema de produção, introduzindo novos setores, rompendo velhos e estabelecendo novos sistemas.

As interações entre instituições e empresas, principalmente aquelas ligadas à área de Ciência e Tecnologia (C\&T), são uma importante alavanca das inovações, porque a partir dessas interações são estabelecidos canais distintos de aprendizado (learning by doing; by using; by interacting; by searching, entre outras), com múltiplas fontes internas e externas de informação e conhecimento.

Nas relações, os atores criam uma "interdependência sistêmica, não formal, dentro dos sistemas produtivos, e que são condicionados pelo ambiente em que a estrutura está inserida" (SOUZA; ARICA, 2006). Essas estruturas, por sua vez, têm refletido num cenário mais competitivo para as empresas dos países avançados ou em desenvolvimento, uma vez que a inovação é influenciada, em grande medida, pela existência de um processo permanente de cooperação e aprendizado entre os atores, com papel tão relevante quanto à posse de conhecimento-base no estágio inicial do desenvolvimento de produtos (CASSIOLATO, 1992).

Freeman (1995) ressalta que a partir dos anos 50 havia diferenças significativas entre os Sistemas Nacionais de Inovação dos países europeus, do EUA e do Japão, e que tais distinções contribuíram para o enfraquecimento da idéia de que a P\&D é a única fonte de inovação naqueles países. Segundo o autor, as mudanças técnicas foram atribuídas não apenas às atividades formais de P\&D, mas

${ }^{3} \mathrm{O}$ 'learning-by-interacting', estará presente no fluxo de bens e serviços originados da produção. 
às alterações em áreas relacionadas como educação, treinamento, engenharia de produção, projeto, controle de qualidade, entre outros (FREEMAN, 1995, p. 10), e às relações entre instituições de pesquisa e empresas.

Freeman (1988) ressalta que a economia da antiga URSS, por exemplo, cresceu com certa interdependência entre institutos de pesquisa; setores industriais; e projetos de plantas e importação de tecnologias. As relações entre esses institutos e os agentes eram fracas e dispersas, o que conduziu um sistema que não garantia inovações bem-sucedidas e ganhos de produtividade ao país ${ }^{4}$.

Contudo, o Japão apresentou um bom desempenho econômico que pode ser atribuído às mudanças técnicas realizadas pelas empresas japonesas e, principalmente, às mudanças sociais e institucionais promovidas ou iniciadas pelo MITI (Ministry of International Trade and Industry) a partir de meados dos anos 70 (FREEMAN, 1988).

A atuação do MITI diferia consideravelmente das medidas tomadas por outros departamentos e ministérios na Europa e nos EUA. Os membros do MITI não apenas encorajaram a introdução de novas tecnologias através de investimentos, mas mudaram a forma como esses avanços foram implementados. A instituição estabeleceu um "modo de trabalho que dependia do diálogo contínuo sobre questões relacionadas ao desenvolvimento tecnológico, e que englobava a interação entre pessoas do departamento de P\&D industrial, cientistas e tecnólogos de universidades" (FREEMAN, 1988, p. 332).

A estratégia conjunta de instituições, bancos e o Ministério das Finanças do Japão, voltados à direção da mudança técnica e social, forneceram a base das novas tecnologias e do padrão de mudanças técnicas estabelecidas e difundidas pelo país. Entretanto, desde o período da pós-Segunda Guerra as empresas japonesas estabeleceram o método de assimilação de tecnologias importadas e reprojetavam os seus produtos. E, esse mecanismo de "engenharia reversa criativa" (FREEMAN, 1988, p. 335) resultou em aprendizado contínuo e conferiu maior competitividade a muitas empresas japonesas.

Freeman (1995) ressalta ainda que o Sistema de Inovação japonês contava com fortes relações entre as instituições e empresas e apresentava significativas interações usuário-produtor entre a indústria de aviação e o setor de defesa,

\footnotetext{
${ }^{4}$ Freeman (1995) ressalta a URSS como exemplo emblemático de que os elevados investimentos em
} 
diferentemente da fraca estrutura de relações usuário-produtor apresentada no Sistema da URSS. Outro exemplo relevante é apresentado por CASSIOLATO (1992) em seu trabalho sobre a dinâmica das relações usuário-produtor e os efeitos das relações estabelecidas entre os fornecedores e usuários no setor de automação bancária do Brasil (CASSIOLATO, 1992).

A extensão em que os esforços resultam em inovação depende, de um lado, da escala dos recursos comprometidos nos setores públicos e privados da economia e de outro, de "atitudes e condições sociais e instituições apropriadas, particularmente o Sistema Nacional de Inovação" (FREEMAN, 1988, p. 334). Nesse sentido, a estrutura institucional e as relações sociais ao longo das cadeias têm condições de influenciar significativamente o desempenho das empresas e setores.

Nas últimas décadas, outras duas abordagens têm contribuído para o entendimento do papel atribuído aos dois aspectos para as atividades inovativas das empresas: O Sistema Setorial de Inovação (SSI) e a discussão sobre A Vantagem Competitiva das Nações, que são apresentados a seguir.

\subsubsection{Sistema Setorial de Inovação}

MALERBA (2002) apresentou um arcabouço inspirado no SNI que foi denominado Sistema Setorial de Inovação (SSI), em que também é ressaltado o aprendizado interativo no processo de inovação.

O Sistema Setorial de Inovação pode ser definido como um grupo de empresas envolvidas no desenvolvimento e na produção, gerando e utilizando tecnologias setoriais, atividades essas que podem ser executadas em dois caminhos: "através de processos de interação e cooperação no desenvolvimento de artefatos tecnológicos; e por meio de competição e seleção em atividades inovativas de mercado" (MALERBA; ORSENIGO, 1997, p. 111).

A competitividade das empresas é influenciada, nessa perspectiva, pelo nível em que diferentes setores (ou indústrias) operam em termos de regimes tecnológicos (SOUZA; ARICA, 2006, p. 83), o que se aproxima da tipologia sobre o 
padrão de produção e difusão de inovações de Pavitt (1984).

No Sistema Setorial há três dimensões que afetam a geração e adoção de novas tecnologias em nível setorial:

- Conhecimento - a mudança contínua do conhecimento para a inovação pode levar à redefinição das fronteiras setoriais uma vez que as fontes de conhecimento são diferentes em cada setor e como resultado das alterações na base de conhecimento;

- Atores e redes - as características do conhecimento influenciam os atores relevantes e as redes que compõem esse sistema setorial e podem, muitas vezes, determinar o surgimento de novos atores para os mesmos setores; e

- Instituições - podem afetar a taxa de mudança técnica, a organização das atividades inovadoras e o desempenho do sistema em todos os setores. A natureza dessas instituições nacionais e específicas do setor pode imprimir novas tendências para a inovação setorial.

É importante destacar que a inovação e a produção são processos orientados pela interação sistemática entre atores e por suas estruturas cognitivas. Nesses processos, a emergência ou a transformação da demanda, composta por usuários e consumidores, "é o maior fator de redefinição dos limites das fronteiras do sistema setorial, de estímulo à inovação" e de organização das atividades de produção (MALERBA, 2002, p. 343).

Os atores interagem através de canais de comunicação que são conformados pela atuação das instituições setoriais (MALERBA, 2002) e que podem apresentar processos de aprendizado específicos, competências, estruturas organizacionais, crenças, objetivos e comportamentos distintos de um setor para outro.

O aprendizado e a acumulação de conhecimento, por sua vez, afetam consideravelmente a taxa e a estrutura das atividades inovativas e conferem diferenças setoriais no padrão de inovação ${ }^{5}$. (MALERBA; ORSENIGO, 1997, p. 94).

O domínio tecnológico dos setores muda com o tempo, em virtude do comportamento e da organização das empresas, e difere de um país para outro (MALERBA, 2002).

Nesse sentido, o desempenho de um setor na Europa, EUA ou Japão pode ser atribuído às vantagens e deficiências setoriais nas fontes de conhecimento, ao

\footnotetext{
${ }^{5}$ Contudo, há algumas similaridades entre os países que participam de atividades inovativas numa
} 
tipo e à competência dos atores e redes envolvidos e ao papel desempenhado pelas instituições setoriais. Ambos os aspectos (deficiências e vantagens setoriais), por sua vez, refletem o comportamento e a organização das empresas e o regime tecnológico assumido em cada país.

As perspectivas do Sistema de Nacional de Inovação (SNI) e Sistema Setorial de Inovação (SSI) destacam o papel das instituições e das empresas participantes desses sistemas, uma vez que a partir das interações realizadas entre esses atores, são intensificados os canais para a troca de informações e podem emergir novas oportunidades tecnológicas em processos e produtos. Entretanto, enquanto o SNI dá atenção aos atores e suas relações dentro de limites nacionais, o SSI está voltado às indústrias e aos processos de competição, cooperação e de formação de redes (MALERBA; ORSENIGO, 1997, p.112).

\subsubsection{Elementos da vantagem competitiva}

A abordagem de Michael Porter utiliza outro recorte que pode contribuir para a análise sobre o processo de interação e aprendizado inovativo. Segundo o autor, há diferenças nacionais em práticas administrativas e abordagens que criam vantagens e desvantagens na competição entre diferentes tipos de indústria. Os aspectos inerentes à estrutura de um país decorrem dos sistemas educacionais, da história social e religiosa e das estruturas familiares, entre outras condições nacionais, podem influenciar a maneira pela qual as empresas são organizadas (PORTER, 1993b).

As nações determinam, assim, potencialidades na utilização de seus insumos e recursos e, em cada país, os setores industriais e seus segmentos não apresentam estruturas homogêneas na busca por vantagens competitivas de longo prazo. Para ele, a vantagem nacional numa indústria pode ser explicada pelo equilíbrio entre o contexto em que as empresas são criadas, organizadas e dirigidas e da natureza da rivalidade interna (PORTER, 1993b).

Porter apresenta um panorama macroeconômico, e não setorial, das 
atividades inovativas, considerando que o aprendizado tem efeitos sobre as vantagens das firmas no interior de um ramo industrial, refletindo nas vantagens competitivas das nações. Além disso, são ressaltadas as estratégias dos segmentos da cadeia de valor e a relevância das ligações estabelecidas entre esses agentes e as instituições voltadas à cada atividade em âmbito nacional e intrapaíses.

O conhecimento é apresentado como uma vantagem competitiva dinâmica que pode ser criada através dos elementos e das interações entre elementos que compõem o diamante. Nesse sentido, enquanto a abordagem de Sistema de Inovação está mais vinculada ao processo de inovação tecnológica e ao campo da C\&T, o diamante refere-se aos aspectos da competitividade comercial e à gestão empresarial (SOUZA; ARICA, 2006).

O conhecido diamante de Porter apresenta quatro características que podem explicar o desempenho e a vantagem competitiva das nações:

a) condições de fatores (recursos, habilidades, tecnologias, capital, etc);

b) condições de demanda;

c) elos para relacionar e auxiliar indústrias; e

d) estratégia das empresas, estruturas e competição.

As vantagens nesses elementos do Diamante são importantes porque "as interações entre determinantes introduzem novas informações, novos conhecimentos e novas empresas na competição da indústria” (PORTER, 1993c).

Contudo, não é necessário deter vantagens em todo o diamante (Porter, 1998b). Nas indústrias mais sofisticadas, por exemplo, a vantagem competitiva depende do ritmo da inovação, que por sua vez é explicada pela capacidade de desenvolver canais consistentes com os compradores (internos e externos) e com os fornecedores. Já as outras indústrias podem desenvolver sua capacidade competitiva por meio de uma abertura à competição internacional que compense os efeitos negativos da rivalidade interna muito acirrada (PORTER, 1993c).

A discussão sobre o padrão tecnológico e setorial, o Sistema Nacional e a Vantagem Competitiva enfatizam o caráter sistêmico do processo inovativo porque, em cada perspectiva, as melhorias em produtos e processos são influenciadas e alteradas pela busca permanente de ganhos econômicos e pela interdependência entre aspectos extramercados e sociais específicos a cada empresa, setor ou região.

Cabe ressaltar que a sustentação do padrão inovativo em cada uma dessas 
perspectivas de análise também depende, em maior ou menor grau, do cenário interno às empresas e instituições envolvidas na criação e incorporação de melhorias.

As empresas e instituições deparam-se, freqüentemente, com fortes oscilações no meio econômico e industrial, o que incita a formulação de estratégias distintas nas etapas de projeto, produção, comercialização e distribuição de seus produtos e serviços e imprime um componente de mudança técnica entre as empresas. A literatura sobre o aprendizado organizacional e capacidade de absorção interna às empresas, apresentados a seguir, também podem suscitar importantes contribuições para o entendimento sobre o aprendizado inovativo e as relações usuário-produtor.

\subsection{0 aprendizado inovativo e a mudança técnica}

O aprendizado inovativo está ligado à idéia de uma multiplicidade de processos pelos quais as empresas acumulam, continuamente, uma diversidade de estoque de conhecimentos e habilidades que se refletem na direção da mudança técnica de cada agente e dos setores (MALERBA, 1992; QUEIROZ, 2006, p. 194).

$O$ processo de aprendizado pode contribuir de forma significativa para a mudança técnica, principalmente a mudança técnica de caráter incremental. A principal justificativa é que as modificações marginais realizadas ao longo do processo de inovação reduzem as dificuldades enfrentadas entre a geração de inovação e sua difusão porque há o acompanhamento sistemático e o aperfeiçoamento das tecnologias envolvidas na inovação radical.

Outro fator importante é que as alterações incrementais, freqüentemente imperceptíveis para os consumidores, também ocasionam crescimento da eficiência técnica, aumento da produtividade e da qualidade, redução dos custos e a ampliação das aplicações de um produto ou processo, definindo as trajetórias das inovações radicais (LEMOS, 2000, p. 159; QUEIROZ, 2006, p. 198).

Nesse sentido, a mudança técnica incremental das empresas pode estar voltada para as melhorias no rendimento de um dado processo de produção; dos insumos, da escala e da organização desse processo; e para a diferenciação 
horizontal e/ou vertical de produtos (MALERBA, 1992).

Os processos de aprendizado estão relacionados, principalmente, à solução de problemas e ao aperfeiçoamento contínuo das tecnologias, condicionando a capacitação tecnológica das empresas. Além disso, esses processos de aprendizado não são automáticos, mas determinados pela experiência acumulada ao longo do tempo no interior das empresas e por fluxos de informações a partir das interações com fontes externas de conhecimento.

O caráter cumulativo do aprendizado tem dois efeitos para o desenvolvimento das empresas: ele não só leva à acumulação de capacidades internas às empresas, mas determina o aumento da capacidade de aprender (learning by learning): quanto mais uma organização aprende, mais eficiente ela vai gerenciar seu processo de aprendizado (QUEIROZ, 2006, p. 197).

Para grande parte das empresas, os processos de aprendizado encerram, cada qual, um mecanismo específico de geração e incorporação de conhecimentos que determinam, impreterivelmente, um dos caminhos ou mudança técnica incremental a ser estabelecido pelas empresas ou setores. Entretanto, esse processo carrega um forte componente de incerteza que pode restringir investimentos futuros e minar as estratégias voltadas ao aprendizado.

Por conta de todos esses aspectos, Malerba (1992, p. 848) destaca quatro características principais do aprendizado:

- É um processo custoso e interno às empresas;

- Está associado a diferentes fontes de conhecimento que podem ocorrer interna ou externamente às empresas;

- É cumulativo e pode afetar e aumentar o estoque de conhecimento das empresas. Por esse motivo, as empresas podem ser caracterizadas por diferentes níveis e tipos de capital de conhecimento, ao longo do tempo.

- O estoque de conhecimento da empresa gera conhecimento local e incremental.

A fonte de aprendizado pode ser interna e externa à empresa (CASSIOLATO, 2004). O aprendizado interno do tipo learning-by-doing; learning-by-using; e learning-by-interacting estão ligados às funções principais das empresas, como produção, P\&D, marketing e organização (CASSIOLATO, 2004). Já o aprendizado externo do tipo learning by interacting; learning by searching, assim como os transbordamentos de conhecimento e os investimentos em pesquisa, por sua vez, 
são realizados através das relações sociais de caráter vertical e horizontal, estabelecidas entre empresas e instituições ao longo da cadeia (MALERBA, 1992; LEMOS, 2000):

- Learning by doing - pode refletir-se no desenvolvimento de capacitações específicas, tecnológicas e organizacionais, e em esforços de aprendizado com a experiência própria na produção (MALERBA, 1992; LEMOS, 2000);

- Learning by using - relacionado ao uso de produtos, maquinaria e insumos (MALERBA, 1992);

- Learning by interacting - relacionado a qualquer interação com fontes de conhecimento a jusante e a montante (com fornecedores e usuários) ou é obtido por meio da cooperação com outras empresas na indústria (MALERBA, 1992);

- Learning by searching - obtido a partir dos avanços na ciência e tecnologia externos à empresa e que promovem a absorção de novos desenvolvimentos na ciência;

- Transbordamentos interindústria - relacionado ao que os competidores e outras empresas estão fazendo.

- Pesquisa - fonte de aprendizado externo que está relacionada, principalmente, às atividades formais de $P \& D$ voltadas para gerar novo conhecimento (MALERBA, 1992).

Um dos aspectos essenciais do processo de aprendizado interno é o seu caráter informal. As tecnologias e especificidades técnicas s̃o transferidas para outros agentes através da socialização dos processos learning-by-doing e learningby-using (BRITO, 2004), sem contratos ou regras de conduta formais previamente estabelecidas entre as empresas.

As fontes internas freqüentemente combinam-se com fontes de aprendizado externas, provenientes de outras empresas, fornecedores ou usuários de produtos (CAMPOS et al, 2003), as quais não substituem o aprendizado interno, mas aumentam a velocidade e podem modificar a sua direção (CASSIOLATO, 2004, p. 5), interferindo na dinâmica competitiva das empresas.

$O$ aprendizado externo do tipo learning-by-imitating e learning-bycooperating (CASSIOLATO, 2004, p. 5-6) e learning by interacting, por exemplo, podem ocorrer a partir de

relações estabelecidas entre usuários e produtores, por meio da colaboração formal e informal entre os agentes, da mobilidade de 
trabalhadores capacitados entre as empresas, e a partir do desmembramento de novas empresas das existentes, de universidades e centros de pesquisa públicos (BRESCHI; MALERBA, 2001, p. 819).

A literatura também tem apresentado inúmeros outros formatos de relações a jusante e a montante direcionadas ao aprendizado interno e externo à firma e aos ganhos econômicos ao longo das cadeias industriais.

As parcerias na distribuição e comercialização de um mesmo produto, as joint ventures estabelecidas entre empresas de etapas distintas na fabricação de um mesmo produto e até as aquisições de empresas, entre outros, possibilitam a exploração de novas oportunidades técnicas e comerciais. Além disso, podem ocasionar o aprimoramento de processos e produtos, a partir do contato direto com as necessidades efetivas e potenciais dos consumidores, resultando na inovação dos setores industriais.

Esses processos nem sempre são vantajosos para a formação de novas capacidades de todos os participantes envolvidos nos acordos. As parcerias estabelecidas pelas empresas podem resultar na inserção em novos mercados, mas ficam restritas a objetivos comerciais e, freqüentemente, podem repercutir pouco na capacitação tecnológica das empresas no longo prazo.

As relações estabelecidas entre os produtores das indústrias de máquina e seus usuários, ao contrário, são apontadas como uma fonte importante de criação de conhecimento que reflete no desempenho industrial de maneira peculiar, principalmente nas áreas de projeto e de produção no interior das empresas.

A principal contribuição dessas relações é que elas podem otimizar o aprendizado organizacional e a criação de capacitações internas voltadas à inovação. O contato entre produtores de máquinas e seus usuários nas áreas de projeto e produto desencadeia alterações na capacidade para absorver e aplicar tecnologias e técnicas de produção e permite o reconhecimento de novas oportunidades.

Nesse sentido, as inovações incrementais são dinamizadas porque as necessidades efetivas e as melhorias potenciais tornam-se mais acessíveis às empresas e aos setores a partir da proximidade e o diálogo constante entre os funcionários na etapa de projeto e no chão-de-fábrica das empresas.

Cabe destacar que este aspecto não minimiza a relevância das estratégias comerciais vislumbradas por empresas de outros setores. Mas, como o desempenho 
econômico-industrial é ancorado, principalmente, pela busca constante por novas fontes conhecimento, por relações extramercados e pelo aprendizado organizacional, as relações usuário-produtor assumem um papel significativo no debate sobre a inovação em economias industriais.

\subsubsection{A Capacidade de absorção e o Aprendizado Organizacional}

Nos últimos anos, a literatura sobre competência dinâmica e capacidade de absorção das empresas apresenta os requisitos e características relevantes para que as estratégias resultem, de fato, em produtos e processo competitivos e no desempenho econômico-industrial.

O conceito de competência dinâmica em novos projetos, na qualidade de produtos e na eficiência de processos enfatiza o desenvolvimento de mecanismos de aprendizado organizacional, considerando que a vantagem competitiva das empresas pode ser explicada por seus processos internos, por seus ativos e por sua posição no mercado (TEECE; PISANO, 1994).

Teece e Pisano (1994) definem a competência dinâmica como "subconjunto de competências que permitem à empresa criar novos produtos e processos, e responder às mudanças nas circunstâncias do mercado" (TEECE; PISANO, 1994, p. 541). Essas competências são as condições que as empresas detêm para explorar as fontes externas e internas de capacidades específicas e para desenvolver novos mecanismos de vantagem competitiva.

Segundo os autores, há três fatores que interferem na capacidade dinâmica das empresas e podem ser considerados na discussão sobre o aprendizado organizacional nas economias industriais:

1. Processo administrativo e organizacional - refere-se às rotinas e padrões das práticas atuais e de aprendizado. Há três dimensões dos processos administrativos que determinam a capacidade dinâmica das empresas:

a) Integração - as variações na forma como as empresas coordenam as atividades requeridas têm um impacto importante sobre variáveis de desempenho como custos, tempo de espera e qualidade (TEECE; PISANO, 1994, p. 542) e são específicas à natureza da empresa. 
b) Aprendizado - é o processo pelo qual a repetição e experimentação na empresa possibilitam a execução de tarefas com melhor desempenho e mais rapidez, e a identificação de novas oportunidades. A dinâmica competitiva pode ser alterada pelo processo de aprendizado organizacional (TEECE; PISANO, 1994).

c) Reconfiguração e Transformação - refere-se à capacidade de reconfigurar e transformar uma habilidade organizacional apreendida para acompanhar as transformações internas e externas às empresas.

2. Posições: a posição da empresa quanto aos seus ativos mais difíceis de transacionar - ativos tecnológicos, ativos complementares, ativos financeiros e ativos locacionais.

3. Trajetória: São as alternativas disponíveis para as empresas em termos de dependência da trajetória (path dependences) e das oportunidades tecnológicas (TEECE; PISANO, 1994).

Primeiramente, a dependência da trajetória implica que as empresas têm seu desempenho e dinâmica competitiva condicionados aos investimentos e estratégias realizados no passado. O conceito de path dependence pode ser explicado como:

seqüência de escolhas econômica que é condicionada, a cada momento, pela situação criada por escolhas anteriores e que, ao mesmo tempo, tende a reforçá-las sem que esta conseqüência ser considerada pelos agentes que tomam decisões (HELLER, 2006, p. 260).

As oportunidades tecnológicas, por sua vez, são definidas pelo contexto em que a ciência básica e as rupturas científicas são conduzidas. Essas oportunidades podem não ser externas à indústria, porque dependem da capacidade para engajar em apoios à pesquisa básica e são alimentados por atividades inovativas em si. Além disso, são afetadas pela estrutura organizacional associada às instituições de pesquisa básica (TEECE; PISANO, 1994).

Além dos processos administrativos, da posição e da trajetória adotada pelas empresas determinarem diferenças significativas no aprendizado organizacional, destaca-se também o grau de especialização ou diversificação da tecnologia base, os investimentos realizados no longo prazo e as características das relações sociais desenvolvidas ao longo do tempo como fatores relevantes na dinâmica de incorporação e aplicação de conhecimentos internos às firmas.

As competências incorporadas às rotinas das empresas possibilitam a criação de inovações e o desempenho industrial satisfatório porque refletem na "capacidade 
de absorção" desenvolvida no interior dessas empresas.

Cohen e Levinthal (1990) definem a capacidade de absorção como a habilidade desenvolvida por uma empresa para "reconhecer o valor de uma nova informação externa, assimilá-la e aplicá-la para fins comerciais" (COHEN; LEVINTHAL, 1990, p. 128).

A capacidade de absorção também pode ser definida como "a habilidade de uma organização para aprender por muitas fontes, incluindo as informações externas" (AAGE, 2005, p. 110), sendo formada a partir dos "subprocessos de aquisição, implementação e comercialização das informações externas, que é associada à acumulação interna de conhecimento" (AAGE, 2005, p. 110-111). Nesse sentido, é apresentada como a capacitação dos atores para absorver e explorar os atributos e as condições para o aprendizado organizacional em produtos e processos voltados ao desempenho inovativo no longo prazo. E pode, de fato, transformar o conhecimento existente em conhecimento adequado às necessidades da empresa.

Uma vez que depende da interface direta das empresas com o meio externo e da forma como as informações podem ser transferidas entre os departamentos e entre as subunidades (BATHELT et al, 2004), a capacidade de absorção das empresas é o fator determinante do seu nível de aprendizado organizacional e de sua competitividade.

As empresas têm ao seu alcance o conhecimento inicial - ou conhecimentobase - que pode alterar as tarefas de aprendizado subseqüentes; e a habilidade para resolver problemas - que permite aos indivíduos adquirir capacidades relacionadas às suas, e pode desencadear a criação de novos conhecimentos (COHEN; LEVINTHAL, 1990, p. 130). O conhecimento-base facilita o aprendizado de informações relacionadas ao mesmo produto ou tecnologia porque inclui um conjunto de habilidades de aprendizado (COHEN; LEVINTHAL, 1990, p. 130) transferidas através das atividades exercidas por diferentes atores. Mas, os indivíduos nem sempre possuem o conhecimento de contexto (ou conhecimentobase) apropriado para fazer o novo conhecimento completamente inteligível (COHEN; LEVINTHAL, 1990, p. 129).

Aage (2005) também ressalta que o conhecimento-base de uma empresa aumenta sua habilidade para reconhecer o valor de novas informações externas e a identificação e avaliação de futuras oportunidades técnicas; amplia o processo de aprendizado das informações externas para construir 
o conhecimento organizacional, a criatividade e a habilidade para resolver problemas através da recombinação de novos e velhos conhecimentos" (AAGE, 2005, p. 111).

Como resultado, o conhecimento-base permite à empresa predizer mais cuidadosamente a "natureza e as potencialidades comerciais dos avanços tecnológicos, e assegurar a capacidade de absorção futura para a organização, dentro de certo campo de atividade" (AAGE, 2005, p. 111).

As estruturas de conhecimento -base apresentam um caráter cumulativo e de "path dependence", que tende a restringir a atuação das empresas a um determinado domínio tecnológico (COHEN; LEVINTHAL, 1990, p. 137), aproximando-as do padrão tecnológico setorial analisado por Pavitt (1984). Há dois efeitos do path dependence para a capacidade de absorção e para o desempenho das empresas: interfere na incorporação e aprimoramento das habilidades futuras e se reflete na formação de expectativa sobre as oportunidades da empresa.

Entretanto, a interrupção de investimentos em uma determinada capacidade de absorção pode dificultar a incorporação e o uso dos conhecimentos futuros porque as empresas perdem a habilidade para identificar e valorizar esses novos conhecimentos - processo denominado de "lockouf" (COHEN; LEVINTHAL, 1990, p. 136) ${ }^{6}$. A falta de investimentos também pode restringir possíveis oportunidades tecnológicas futuras porque as expectativas das empresas ficam limitadas ao domínio tecnológico desenvolvido no passado.

As empresas com alto nível de capacidade de absorção, por exemplo, tendem a explorar mais as oportunidades presentes no meio, independente do desempenho econômico atual. As empresas com modesta capacidade de absorção, por outro lado, tendem a ser mais conservadoras, pesquisando novas alternativas apenas em resposta às falhas de alguns dos critérios de desempenho que não são definidos em termos de mudança técnica (COHEN; LEVINTHAL, 1990, p. 137), como queda dos preços ou redução dos insumos aplicados na produção.

Entretanto a capacidade de absorção não é determinada apenas pelo desempenho passado da organização. Cohen e Levinthal (1990) consideram que a intensidade de esforços e o tempo gasto na resolução dos problemas iniciais antes

\footnotetext{
${ }^{6}$ A empresa que não investe em capacidade de absorção também pode enfrentar custos mais elevados para alavancar os novos conhecimentos e incorporá-los às suas práticas (COHEN; LEVINTHAL, 1990, p. 136).
} 
de mover-se para problemas mais complexos também são relevantes para 0 desenvolvimento tecnológico (COHEN; LEVINTHAL, 1990, p. 130) e para as estruturas de conhecimento interno às empresas. Além disso, a capacidade de absorção refere-se não apenas à aquisição ou assimilação, mas à habilidade para explorar as informações e os contatos diretos com as informações externas, dentro das subunidades e através dos departamentos que se tornam relevantes para 0 desempenho das empresas.

Diversas estruturas de conhecimento coexistem no mesmo meio e as tentativas de assegurar essa variedade dentro de uma única empresa podem levar a objetivos divergentes, ou desviar visões que atrapalham os objetivos da empresa. $O$ conflito de estruturas, na maioria das vezes, prejudica as capacidades de aprendizado e pode restringir contatos externos necessários para o desempenho e crescimento das empresas (BATHELT et al, 2004), o que justifica a atuação de gatekeepers na intermediação entre o meio externo e interno e no compartilhamento das informações dentro dos departamentos.

O termo gatekeepers pode ser definido como grupo de funcionários mais capacitados que são responsáveis pela interface da empresa com o meio externo ou entre subunidades da empresa. Eles podem dinamizar a capacidade de absorção das empresas de duas maneiras: atuação centralizadora - na situação em que é difícil a assimilação das informações pela equipe de funcionários, eles traduzem essas informações de uma forma mais compreensível; atuação difusa - nas situações em que a informação é fechada e relacionada a uma atividade, podendo ser assimilada sem dificuldades, os funcionários (gatekeepers) podem monitorar o meio sem exercer uma função centralizadora (COHEN; LEVINTHAL, 1990, p. 132).

A transferência de informações realizada pelos gatekeepers e, conseqüentemente, o caminho tecnológico a ser seguido pela empresa é influenciado pelo caráter do conhecimento especializado das pessoas que recebem essas informações.

Os funcionários especializados afetam o conhecimento que chega por meio dos canais de comunicação e é expedido pelos gatekeepers locais (BATHELT et al, 2003) porque compartilham linguagens e símbolos que possibilitam a incorporação e exploração das informações provenientes do meio externo à empresa. Adicionalmente, o conhecimento especializado também imprime um caráter de especificidade à capacidade de absorção da empresa porque atribui diferentes graus 
de abertura às oportunidades tecnológicas emergentes que dificultam a compra e incorporação rápida do conhecimento por outras empresas e determinam o seu distanciamento tecnológico.

Outro fator importante para a capacidade de absorção é a estrutura do conjunto de conhecimento da empresa - ou o grau de especialização do conhecimento (AAGE, 2005, p. 111). As empresas com conjunto de conhecimento muito especializado freqüentemente enfrentarão dificuldades de comunicação com as fontes externas, devido aos obstáculos impostos pelos canais de comunicação. Por outro lado, as empresas com conhecimento mais amplo compartilharão mais facilmente as informações das fontes de comunicação externa. (AAGE, 2005).

$\mathrm{Na}$ etapa de produção, por exemplo, é necessário desenvolver um estoque de conhecimento voltado às características da etapa ou produto em andamento, e quanto mais as estruturas de conhecimento são diferenciadas, maior o nível de estoque requisitado e os investimentos na comunicação das informações.

Nesse sentido, o desenvolvimento do estoque requer uma estrutura de comunicação entre o meio externo e as subunidades da empresa (COHEN; LEVINTHAL, 1990, p. 132). Mas, para que essa estrutura de comunicação contribua de fato para a capacidade de absorção e assim resulte em aprendizado organizacional no longo prazo, as empresas enfrentam um trade-off na eficiência entre a comunicação interna e a habilidade das subunidades para assimilar e explorar as informações originárias de outras subunidades ou do meio.

Esse fenômeno caracterizado como trade-off da capacidade de absorção de olhar para dentro (inward-looking) e olhar para fora (outward-looking) (COHEN; LEVINTHAL, 1990) reflete o descompasso na estratégia de empresas industriais e como a diversificação da estrutura do conhecimento pode afetar o desenvolvimento da capacidade de absorção.

As empresas enfrentam esse dilema entre especializar seu conhecimento na comunicação interna ou investir em estruturas com diversidade de conhecimentos (COHEN; LEVINTHAL, 1990, p. 133) porque, de um lado, a especialização impõe restrições à habilidade para adquirir informações externas, devido à distância cognitiva entre o meio interno à empresa - conhecimento-base - e as fontes de informação externa (AAGE, 2005, p. 111). De outro lado, a aquisição de informações provenientes do meio externo não sustenta o aprendizado organizacional sem uma base de informações internas comuns aos departamentos. 
A distância cognitiva comum às estruturas de conhecimento especializadas (distantes das fontes externas) pode ser definida como o "ruído semântico que dificulta a comunicação" (AAGE, 2005, p. 111). Quanto maior o desacordo entre a linguagem e a orientação cognitiva, maiores serão as dificuldades - como consumo de tempo, codificação e transferência do conhecimento e enganos - na aquisição de informações externas (AAGE, 2005, p. 111).

Com essa afirmação, Aage (2005) considera que as empresas têm ao seu alcance duas possibilidades voltadas à capacidade de absorção que, na maioria das vezes, são excludentes entre si porque os gatekeepers podem influenciar pouco o nível de aprendizado de informações externas às empresas.

Nonaka e Takeuchi (1997) ressaltam que a 'cultura organizacional' consiste de "crenças e conhecimentos compartilhados pelos membros da organização" (NONAKA; TAKEUCHI, 1997, p. 49). E a criação e a expansão desses conhecimentos são determinadas fundamentalmente pela interação social entre os conhecimentos tácitos e os conhecimentos explícitos (dimensão epistemológica), sendo realizados de maneira individual, grupal, organizacional e interorganizacional (dimensão ontológica), e formam uma espiral dinâmica (NONAKA; TAKEUCHI, 1997, p. 52), ou espiral do conhecimento.

Diferentemente do conceito de capacidade de absorção apresentada por Cohen e Levinthal (1990) e Aage (2005), a espiral do conhecimento analisada por Nonaka e Takeuchi (1997) é utilizada para explicar que a criação do conhecimento é iniciada no plano individual, com a exploração de informações de caráter tácito, e vai se expandindo em termos de interação e de modos de conversão do conhecimento, rompendo as fronteiras entre departamentos, divisões e organizações (NONAKA; TAKEUCHI, 1997, p. 82).

Segundo essa visão, as empresas inovam de dentro para fora, com o propósito de resolver seus problemas técnicos e se adaptar ao ambiente competitivo, utilizando quatro modos diferentes de conversão do conhecimento (NONAKA; TAKEUCHI, 1997, p. 62) (Quadro 2): 


\begin{tabular}{|c|c|c|}
\hline & $\begin{array}{c}\text { Conhecimento } \\
\text { Tácito }\end{array}$ & $\begin{array}{c}\text { Conhecimento } \\
\text { Explícito }\end{array}$ \\
\hline $\begin{array}{c}\text { Conhecimento } \\
\text { Tácito }\end{array}$ & Socialização (1) & Externalização (2) \\
\hline $\begin{array}{c}\text { Conhecimento } \\
\text { explícito }\end{array}$ & Internalização (4) & Combinação (3) \\
\hline
\end{tabular}

Fonte: Nonaka; Takeuchi (1997).

Quadro 2 - Modos de conversão do conhecimento.

- Socialização - conversão do conhecimento tácito em conhecimento tácito (NONAKA; TAKEUCHI, 1997, p. 68), constitui um processo de compartilhamento de experiências que inclui aspectos técnicos - know how e habilidades - e cognitivos como os esquemas, paradigmas, perspectivas e crenças incorporadas e criadas ao longo do processo de aprendizado organizacional (NONAKA e TAKEUCHI, 1997, p. 67). A partir daí, ocorre a criação do conhecimento tácito e de habilidades técnicas específicas à empresa (NONAKA; TAKEUCHI, 1997, p. 80).

- Externalização - conversão do conhecimento tácito em conhecimento explícito, normalmente orientado pela metáfora e/ou analogia, visando o estímulo ao processo criativo (NONAKA; TAKEUCHI, 1997, p. 72).

- Combinação - conversão do conhecimento explícito em conhecimento explícito (NONAKA; TAKEUCHI, 1997, p. 68), que sistematiza os conceitos em um sistema de conhecimento.

- Internalização - conversão do conhecimento explícito em conhecimento tácito, está intimamente relacionada ao aprendizado organizacional (NONAKA; TAKEUCHI, 1997, p. 68) porque incorpora os conceitos sistematizados na etapa de combinação às rotinas e transforma-os em conhecimento tácito, fechando o ciclo de aprendizado organizacional.

As quatro fases de transformação e a internalização do conhecimento tácito não dispensam um contexto adequado às atividades em grupo e propício à acumulação individual. Além disso, a sustentação do espiral do conhecimento depende de cinco condições internas às empresas: intenção; autonomia; flutuação e caos criativo; redundância; e variedade de requisitos:

Em primeiro lugar, a intenção é "expressa por padrões organizacionais ou visões que podem servir para avaliar e justificar o conhecimento criado" (NONAKA; 
TAKEUCHI, 1997, p. 84). É criada através do estímulo dos funcionários para julgar a veracidade das informações.

Em segundo lugar, a autonomia no nível individual amplia as chances de os indivíduos se motivarem para compartilhar informações e pode facilitar o surgimento de idéias originais.

A flutuação é importante para o aprendizado organizacional na medida em que introduz uma ruptura das rotinas e hábitos sedimentados pelos funcionários da empresa. $\mathrm{E}$, ao determinar o colapso das estruturas cognitivas, pode desencadear o aprimoramento do sistema de conhecimento interno (NONAKA; TAKEUCHI, 1997, p. 89). O caos criativo também exerce esse mesmo papel no processo de aprendizado organizacional uma vez que as pessoas ficam mais centradas na resolução dos problemas propostos pela crise (NONAKA; TAKEUCHI, p. 90, 1997).

A quarta condição para a existência do espiral do conhecimento é a redundância das informações ou exigências operacionais. Esse termo é tratado por Cohen e Levinthal (1990) como "sobreposição de conhecimento", e refere-se à "sobreposição intencional das informações sobre as atividades da empresa, responsabilidades da gerência e sobre as empresas como um todo" (NONAKA; TAKEUCHI, 1997, p. 92), que são trocados mutuamente entre os departamentos da empresa e podem acelerar o processo de criação de conhecimento ${ }^{7}$.

A quinta e última condição para o aprendizado organizacional é a variedade de requisitos - também definida por Cohen e Levinthal (1990) como diversidade do conhecimento especializado interno à empresa.

A variedade interna de requisitos pode ajudar a empresa a enfrentar as flutuações do meio externo porque o acesso a essa diversidade pode ampliar os conhecimentos dos indivíduos e capacitá-los a enfrentar situações adversas (COHEN; LEVINTHAL, 1990). Contudo, a combinação de informações de uma maneira muito diferente entre os indivíduos determina o descompasso entre as estratégias dentro da empresa, levando à limitação das interações entre as subunidades (AAGE, 2005).

O aprendizado organizacional é realizado a partir da atenção, discussão e da comparação de soluções, que facilitam a criação de capacidades comuns entre

\footnotetext{
7 Similarmente à perspectiva de Cohen e Levinthal (1990), Nonaka e Takeuchi (1997) destacam a relevância atribuída à organização interna das empresas japonesas para aumentar a redundância de informações.
} 
as empresas (AAGE, 2005, p. 116) e por este motivo a distância cognitiva entre as empresas é relativamente menor.

Aage (2005) considera que as relações horizontais em sistemas locais tendem a ser mais apropriadas para o processo de aprendizado organizacional das empresas porque nesses sistemas a similaridade nas atividades executadas e a proximidade das competências possibilitam interpretações de maneiras diferentes da mesma informação e um significativo número de soluções para o mesmo problema (AAGE, 2005, p. 117).

Nesse sentido, as empresas podem aproveitar as informações que estão "soltas no ar" para todo o sistema local de produção e alavancar a resolução de problemas comuns ao seu segmento de atuação, o que determina maior intensidade de informações externas no interior do sistema local.

As relações verticais, ao contrário, pressupõem um pequeno número de empresas atuando em segmentos complementares e colaborando para um mesmo propósito. O conjunto de insumos e serviços mais especializado e a complementaridade do conhecimento incorporado ao ambiente interno das empresas possibilitam o desenvolvimento de laços fechados de cooperação entre esses agentes (AAGE, 2005, p. 116), visando o desenvolvimento e melhoria dos fatores de produção e os ajustes de quantidades e preços.

O aprendizado pode ser incentivado por relações de subcontratação de empresas, mas como os conhecimentos são especializados e a distância cognitiva é alta, torna-se mais difícil o acesso de uma única empresa não incluída no processo de cooperação (AAGE, 2005, p. 117), o que pressupõe a atuação de pessoas com capacidade para traduzir as informações técnicas entre os indivíduos.

Segundo Aage (2005), os resultados das relações verticais freqüentemente não são apreendidos pelas demais empresas do sistema local porque a distância cognitiva entre elas pode ser alta. $E$, esse fator diminui a velocidade com que 0 sistema absorve e adquire as informações externas.

O autor aponta as dificuldades enfrentadas por empresas de atividades concorrentes e não considera o papel positivo da especificidade e da complementaridade do conhecimento-base sobre as habilidades e a incorporação de conhecimento externo ao sistema local de produção (AAGE, 2005). 
Cabe ressaltar que as duas dimensões - interação horizontal e vertical podem contribuir distintamente para a melhoria de fatores de produção disponíveis na empresa e nos sistemas locais de produção.

O alto grau de variação e a existência de conhecimento partilhado decorrentes de relações verticais podem ser mais favoráveis à habilidade para processar a informação externa do que é apontado por essa literatura sobre competência dinâmica e capacidade de absorção, e não devem ser excluídas da discussão sobre o aprendizado organizacional.

As práticas de socialização do conhecimento adotadas em empresas japonesas como a Honda, em meados dos anos 90, são emblemáticas dessa particularidade característica do aprendizado organizacional porque possibilitaram a resolução de problemas nos projetos de desenvolvimento (NONAKA; TAKEUCHI, 1997) das empresas.

O processo de socialização pode ocorrer entre a empresa e os escritórios de $P \& D$ ou, mais generalizadamente, entre P\&D, projeto, produção e marketing. No caso das empresas japonesas, a socialização entre os responsáveis pelo desenvolvimento de produtos e os seus clientes e as variadas formas de interações entre os departamentos antes do desenvolvimento dos produtos permitiram o compartilhamento permanente de conhecimento tácito e a criação de idéias para o aperfeiçoamento das atividades e de produtos (NONAKA; TAKEUCHI, 1997, p. 71), dinamizando a cultura organizacional das empresas.

As interações informais puderam reorientar "os modelos mentais" de todos os funcionários para um mesmo objetivo, sem imprimir nessa orientação as fortes pressões comuns ao ambiente de concorrência acirrada que inibiriam a criatividade nos departamentos da empresa. Por esse motivo ajudaram no "compartilhamento de conhecimento tácito e criaram uma nova perspectiva para a empresa" (NONAKA; TAKEUCHI, 1997, p. 70).

Dentre essas relações, o intercâmbio entre fornecedores e usuários reforçou as capacidades individuais (COHEN; LEVINTHAL, 1990, p. 134). E a complementaridade decorrente dessas funções interferiu na capacidade de absorção no interior das empresas e no seu desempenho inovativo (COHEN; LEVINTHAL, 1990, p. 134).

As reuniões regulares entre funcionários de áreas distintas e as redes de comunicação informais e formais estabelecidas por esses agentes, por sua vez, 
dinamizaram a capacidade de absorção da corporação e facilitaram o compartilhamento de informações de caráter tácito e explícito (ou codificado) (NONAKA e TAKEUCHI, 1997, p. 93), repercutindo em novos conhecimentos.

Nesse contexto, a inovação em produtos ou processos e a competitividade industrial são influenciadas pela estrutura do conhecimento-base e pelo grau de compartilhamento e de criação das informações internos e externos às empresas. As relações sociais estabelecidas em várias dimensões da cadeia, particularmente as interações usuário-produtor, podem ajudar esse compartilhamento de informações e o desenvolvimento do Sistema de Inovação.

\subsubsection{O aprendizado das relações usuário-produtor}

A inovação depende, em maior ou menor grau, do potencial que os agentes detêm para desenvolver canais de comunicação no interior das empresas, interempresas e intra-setores e incorporar e trocar informações entre si.

As relações usuário-produtor são um fenômeno importante para a dinâmica do aprendizado inovativo e o desenvolvimento tecnológico de grande parcela de empresas e setores porque o processo colaborativo estabelecido entre empresas usuárias e produtoras de máquinas permite 0 desenvolvimento de novas habilidades, melhorias em produtos e/ou rupturas em padrões pré-estabelecidos.

De acordo com Lundvall, os requerimentos dos usuários e as especificidades técnicas incorporadas e aprimoradas no interior das empresas em tarefas cotidianas são significativos indutores de inovações. Esse processo pode resultar também da formação histórica (FREEMAN, 1982, p. 124; LUNDVALL 1988), mas é direcionado, essencialmente, para o atendimento das necessidades dos usuários localizados fora das unidades de inovação, o que varia consideravelmente entre setores mais dinâmicos ou mais tradicionais.

Entretanto, não é o tipo de necessidade (redução de preço ou maior confiabilidade) que direciona as mudanças inovativas para um ou outro caminho. Recentemente, as empresas têm combinado uma variedade de estratégias - custo, qualidade, tempo ou flexibilização - que dinamizem seu desempenho MUSCAT; FLEURY, 1992) e investem significativamente em melhorias incrementais ou radicais e em novas formas de inserção e competição em novos mercados. Nesse contexto, 
a qualidade das relações e das interdependências existentes entre as empresas é o elemento que pode, de fato, viabilizar o fluxo de conhecimento e a inovação porque essas relações aproximam os potenciais usuários das inovações (LUNDVALL, 1988) e facilitam a difusão de melhorias pelos segmentos produtores.

De um lado, os produtores de tecnologias adotam novos métodos, desenvolvem novos produtos e atendem às necessidades de potenciais usuários fora da unidade inovadora. De outro, os usuários incorporam o conhecimento sobre informações técnicas e eventuais oportunidades tecnológicas às suas estratégias competitivas (LUNDVALL, 1988).

A informação sobre as necessidades dos usuários pode diferir em termos de complexidade e nível de apropriação, e envolve alguns custos e esforços justificados pelo caráter não-público dessa informação (LUNDVALL, 1992).

Lundvall (1992) ressalta que quanto mais complexos forem os requerimentos dos usuários, mais importante será o estabelecimento de canais para a troca de dados entre os diferentes elos da cadeia. Já os custos e o tempo envolvidos no acesso às informações, por sua vez, são relevantes para acelerar o estabelecimento de vínculos de dimensão horizontal e vertical entre as empresas a montante e a jusante.

O contato direto do produtor com seus usuários possibilita processo learningby-using no qual há uma avaliação permanente dos principais gargalos para a produção, a ampliação de possibilidades para inovar e grandes oportunidades para as melhorias em produtos. Além disso, as relações podem interferir na interdependência tecnológica existente nas unidades usuárias e produtoras, em virtude de seu papel de difusor de melhorias para vários segmentos.

A inovação pode refletir em outras demandas por novos equipamentos, o que confere a essa relação um potencial de intensificador das condições inovativas para o produtor. Além disso, é a partir dessas relações que ele terá condições de monitorar as competências e o aprendizado desenvolvidos pelos usuários (LUNDVALL, 1988) e assim pode estimar sua capacidade para dotar novos produtos. Já o usuário, por sua vez, adquire a competência e a confiabilidade de diferentes produtores e conta com a cooperação futura desses atores nos serviços de manutenção e nas melhorias incrementais dos seus produtos.

Cassiolato (1992) destaca que nas interações entre usuários e produtores, a proximidade geográfica entre eles facilita o desenvolvimento do projeto, a 
localização e correção de erros no desenvolvimento de novos produtos. Além disso, o meio em que a tecnologia é desenvolvida tende a se ajustar melhor ao padrão de evolução tecnológica, quando há vínculos entre os agentes e canais para a troca de informações tácitas.

O resultado da interação estabelecida entre usuários e produtores pode ser a mudança técnica incremental ou alguns saltos discretos nas oportunidades técnicas e melhorias de produtos (LUNDVALL, 1992). Contudo, essas relações também podem restringir o processo de inovação, em virtude da dimensão social das interações; da natureza da tecnologia envolvida; e da capacidade técnica requerida pelos agentes participantes do processo.

Em primeiro lugar, cabe ressaltar que a troca de informações entre os usuários e os produtores envolve elevada incerteza e possibilidades de comportamentos desleais e fraudulentos entre os agentes, o que pode minar os benefícios das relações usuário-produtor.

O usuário revela a sua necessidade para o produtor a fim de obter as soluções requeridas, enquanto o produtor, por sua vez, apresenta as especificidades de seus produtos e capacita o usuário com a competência técnica para utilizar o produto. A incerteza de ambos os lados requer o estabelecimento de códigos de comportamento entre usuários e produtores, como mecanismo para viabilizar as transações, e reflete a necessidade de relações de hierarquia não-econômica e de confiança mútua (LUNDVALL, 1988), fundadas em normas e princípios culturais e éticos.

Como a confiança, que é o elemento central das relações, leva tempo para ser construída, essa relação tende a ser durável e não facilmente dissolvida após a fase inicial de sua criação (LUNDVALL, 2003). Esse aspecto é o que justifica duas perspectivas implícitas na dimensão usuário-produtor: a inércia das relações e a natureza fechada e seletiva das relações estabelecidas entre usuários e produtores.

A inércia das relações consiste na forte resistência a mudar e a aversão aos riscos, que pode combinar-se com motivos racionais e reforçar a manutenção das mesmas relações usuário-produtor existentes (LUNDVALL, 1988). Além disso, cada produtor, em geral, tende a manter uma interação fechada com um subconjunto prédefinido de potenciais usuários; enquanto cada usuário se relaciona com um único conjunto específico de usuários (LUNDVALL, 1988).

Em segundo lugar, a natureza da tecnologia envolvida (padronizada, 
complexa) e o seu grau de mudança ao longo do tempo (estacionária, incremental e radical) são os outros fatores que pode acentuar ou limitar o papel das relações usuário-produtor. Lundvall (1992) considera que, quanto mais padronizada e estável for a tecnologia, menor será o papel atribuído à proximidade geográfica e cultural. Por outro lado, quando a tecnologia utilizada for complexa e radical a proximidade geográfica exerce maior influência para o processo inovativo (LUNDVALL, 1992) (Quadro 3).

\begin{tabular}{|c|c|c|}
\hline $\begin{array}{c}\text { Grau de mudança } \\
\text { Tecnológica }\end{array}$ & $\begin{array}{c}\text { Proximidade } \\
\text { geográfica }\end{array}$ & $\begin{array}{c}\text { Relações } \\
\text { usuário-produtor (U-P) }\end{array}$ \\
\hline Estacionária & Papel limitado & Executada à distância. \\
\hline Incremental & $\begin{array}{c}\text { Papel importante para as } \\
\text { relações }\end{array}$ & $\begin{array}{c}\text { Conta com a proximidade geográfica; } \\
\text { Mantém canais de comunicação. }\end{array}$ \\
\hline Radical & $\begin{array}{c}\text { Papel mais importante nas } \\
\text { relações }\end{array}$ & $\begin{array}{c}\text { Conta ainda mais com a proximidade } \\
\text { geográfica; Mantém canais com elementos } \\
\text { de maior subjetividade (confiança). }\end{array}$ \\
\hline Revolução tecnológica & Papel ilimitado & $\begin{array}{c}\text { Relações U-P tendem a encerrar a rede } \\
\text { tradicional de relações. }\end{array}$ \\
\hline
\end{tabular}

Fonte: Adaptado de Lundvall, 1992.

Quadro 3 - Mudança técnica e a relevância da proximidade geográfica nas relações usuárioprodutor.

As tecnologias incrementais, por exemplo, contam com a proximidade geográfica para serem compartilhadas entre as empresas e instituições. Mas essa característica incremental é reforçada, principalmente, pelos fortes laços e canais de comunicação estabelecidos entre os agentes como forma de apreender informações que não estariam disponíveis se eles atuassem isoladamente no mercado.

O terceiro fator das relações usuário-produtor são as características do meio interno às empresas, seja nos departamentos de engenharia ou no chão-defábrica das empresas de máquinas, que podem ser divididos em três características: níveis distintos de formação técnica e atualização profissional; os instrumentos utilizados para a realimentação (feedback) das informações entre os departamentos e o processo de ruptura e incorporação de novos elementos às rotinas, normas e práticas executadas no interior das empresas (figura 2). 


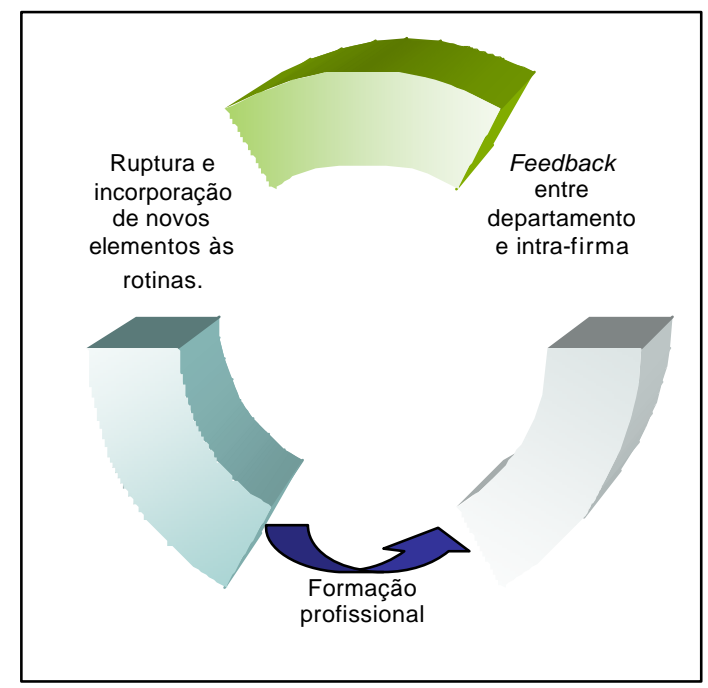

Fonte: Elaboração própria.

Figura 2 - Componentes da geração de conhecimentos interno à empresa

As trocas de experiências e de informações entre usuários e produtores requerem a participação de funcionários competentes em seus campos e familiarizados com as necessidades, procedimentos e rotinas das empresas (COHEN; LEVINTHAL, 1990). Nesse sentido, a principal œntribuição da formação técnica e dos cursos e treinamentos nas áreas de projeto e de produção é que eles repercutem no desenvolvimento do conhecimento-base nas empresas produtoras e usuárias de tecnologias.

Os mecanismos para o retorno das informações entre os departamentos interferem nas capacitações dos usuários e produtores porque a partir conversão permanente de conhecimento tácito em conhecimento explícito, as empresas podem reformular os conceitos nas áreas de desenvolvimento e produção. Além disso, as empresas podem discutir as implicações e limitações impostas por esses conceitos à sua capacidade de absorção e às estratégias competitivas no longo prazo.

A ruptura e aquisição de elementos, por sua vez, correspondem à etapa de revisão dos conceitos e habilidades, incorporados internamente entre os funcionários, e de transformação dos conceitos em novas oportunidades para as empresas. As relações estabelecidas entre empresas produtoras e usuárias de um mesmo setor ou de segmentos distintos difundem novas práticas e melhorias incrementais, e são responsáveis pela ruptura e transformação desses conhecimentos.

Os três componentes - formação técnica; retornos entre os departamentos e 
ruptura e incorporação - interferem constantemente no modo como as empresas criam e incorporam os conhecimentos individuais e coletivos, a partir das relações usuário-produtor e podem ser apontados como mecanismo retroalimentador das relações usuário-produtor.

As interações usuário-produtor podem ter seus benefícios limitados pela capacitação insuficiente dos produtores de insumos e equipamentos e pela falta de competência dos usuários para incorporar as mudanças técnicas ao seu ambiente fabril. Nesse cenário, a adoção de políticas em nível setorial e nacional pode tornarse um instrumento relevante para o adensamento e benefícios econômicos ao longo dessas relações a jusante e a montante.

As mudanças institucionais podem fortalecer a competência dos usuários finais e atuam nas dimensões da ciência básica, na capacidade de absorção da indústria e dos produtores das inovações. Os governos podem intervir, de forma direta ou indiretamente, no estabelecimento e reestruturação de modelos de relações usuário-produtor, considerando os efeitos da mudança técnica e da inovação incremental para toda a economia (LUNDVALL, 1988).

Freeman (1995) aponta que o Sistema Nacional de Inovação (SNI) da URSS em meados dos anos 70 apresentava ligações usuário-produtor somente em algumas áreas importantes para o desempenho da economia, como os setores de aviação e de defesa. Na URSS o processo de aprendizado técnico era explicado, principalmente, pela transferência de tecnologias de escritórios especializados de P\&D para o nível administrativo das empresas (Freeman, 1995), mas os laços entre os demais atores e elos do sistema eram fracos. Por esse motivo, o país enfrentou um período de estagnação do seu desenvolvimento inovativo nas décadas seguintes (FREEMAN, 1995).

O Japão, em contrapartida, apresentava fluxos de informações horizontais e verticais consistentes entre empresas e a atuação sistemática de instituições financeiras e de pesquisa que resultaram num SNI mais forte e com maior dinamismo tecnológico. A colaboração estabelecida entre as empresas do setor automobilístico e seus fornecedores do segmento de robótica e eletrônica é um caso emblemático dos investimentos em relações usuário-produtor naquele país (FREEMAN, 1988, p. 342).

No processo de criação de conhecimento das empresas japonesas, a espiral do conhecimento (NONAKA; TAKEUCHI, 1997) apresentou a reconfiguração de 
informações tácitas visando a criação de novos conhecimentos. E essa reconfiguração freqüentemente era reforçada pela educação, pelo treinamento formal, e pela atuação de gerentes de nível médio que tornaram as visões empresariais, os conceitos de negócios ou de produtos mais operacionais (NONAKA; TAKEUCHI, 1997, p. 76).

Cabe ressaltar que as relações usuário-produtor podem extrapolar os efeitos esperados pelas empresas porque, freqüentemente, a organização em Sistemas locais de produção (SLPS) de micro e pequenas empresas são um ambiente propício à multiplicação das relações entre usuários e produtores. As empresas desses SLPs apresentam características estruturais e mecanismos variados de criação e geração de conhecimentos que têm intensificado o aprendizado sobre entre etapas distintas da cadeia nas economias industriais recentes.

\subsection{Considerações sobre o processo de inovação e o aprendizado inovativo}

O aprendizado tem papel central no processo inovativo de empresas e setores, podendo ser apontado como principal fonte de crescimento econômico desses agentes. Nesse aspecto, parte-se do pressuposto de que a inovação é um elemento endógeno da dinâmica econômica e que há uma relação estreita entre o aprendizado, as melhorias tecnológicas e organizacionais interindústria e interempresa - de caráter radical ou incremental - e o desempenho econômico.

A criação de conhecimento é realizada em diferentes caminhos internos e externos à empresa, mas está associada, freqüentemente, à existência do conhecimento comum, baseado em valores que se apresentam na forma de rotinas e experiências no ambiente interno à empresa. Este processo é determinado, em grande medida, pelas relações sociais, pelo compartilhamento e pelo aprimoramento das informações criadas ao longo da cadeia.

O principal fator determinante desse fenômeno é que o caminho escolhido pelas empresas para incorporar o conhecimento, que se reflete na mudança técnica do setor, só pode ser desenvolvido a partir das interações sociais de caráter horizontal e vertical ao longo da cadeia. Nesse sentido, as empresas têm ao seu alcance diferentes formatos de parcerias e laços informais estabelecidos com 0 
propósito de incorporar e alavancar novas informações e podem, a partir dessas relações, promover as inovações incrementais e pesquisar novas oportunidades tecnológicas.

As relações verticais estabelecidas entre produtores e usuários contam com a complementaridade de informações e as especificidades no conhecimento-base para criar novas possibilidades técnicas e aprimorar o desenvolvimento de produtos e processos. Nas situações em que as empresas enfrentam dificuldades técnicas ou quando são apontados erros na concepção do produto, os especialistas e técnicos das empresas produtoras podem desenvolver novas habilidades voltadas ao processo de criação de conhecimentos. Essas habilidades são cumulativas e podem ser criadas pelo uso de novos materiais ou a partir de técnicas desenvolvidas em outras linhas de negócio.

Esses aspectos imprimem várias possibilidades ao aprendizado organizacional no nível individual e repercutem em melhorias para os segmentos usuários de seus produtos. Nesse sentido, a interação usuário-produtor constitui um importante diferencial competitivo das empresas e setores ao longo das cadeias.

A competência insuficiente dos produtores ou usuários envolvidos nas interações pode interferir negativamente nas relações entre usuários e produtores: de um lado a baixa capacitação dos produtores ou usuários pode inibir a interação e limitar os seus efeitos; de outro lado, as relações mantidas com usuários com demandas muito diversificadas podem dificultar a acumulação de experiências e a exploração de economias de escala.

A reduzida capacitação técnica também pode dificultar a manipulação de algumas operações, e determinar retrabalhos e desperdícios de material e tempo, com efeitos negativos para o desempenho das empresas. Cabe ressaltar que, se por um lado, o aprendizado organizacional e a criação de competências internas às empresas a partir das interações usuário-produtor exercem papel tão marcante sobre a estrutura industrial, por outro, podem ter seus resultados delimitados, em grande parte, pela escassez de estratégias voltadas à capacitação de recursos humanos, pela falta de planejamento e de políticas voltadas ao adensamento dos fluxos de informação e ao aprendizado inovativo no longo prazo.

Os sistemas locais de produção (SLPs) constituem uma alternativa para a superação desses obstáculos ao desenvolvimento de capacitações internas às empresas porque as empresas organizadas nesses arranjos apresentam algumas características intrínsecas à 
sua evolução que podem contribuir significativamente para o fortalecimento do aprendizado individual e coletivo, a criação de habilidades e o enfretamento das dificuldades em termos de capacitação profissional em cada departamento das empresas.

A proximidade geográfica e cultural entre os agentes, a presença de externalidades de caráter incidental ou deliberado, entre outros - e o associativismo que permeia as relações entre empresas de segmentos distintos, particularmente os vínculos estabelecidos entre produtores de máquinas e os usuários de outros segmentos, podem ajudar a intensificar a inovação nas economias industriais de países como o Brasil. O capítulo seguinte tem o propósito de apresentar e discutir algumas das características dos SLPs que transformaram esses sistemas em estruturas propícias ao fluxo de conhecimento das relações usuário-produtor. 


\section{A contribuição dos SLPs para as atividades inovativas}

Os sistemas locais de produção (SLPs) são apontados como importante mecanismo dinamizador do desempenho das empresas, principalmente as de pequeno e médio porte. As estruturas de produção, comercialização e de distribuição desses sistemas locais são movimentadas por relações de caráter horizontal e vertical que possibilitam o aprendizado inovativo em nível individual e coletivo, o crescimento de segmentos industriais e a sua inserção em outros mercados.

Uma das principais vantagens dos SLPs é que eles facilitam a constituição de um ambiente de difusão tecnológica, em virtude principalmente da proximidade entre os agentes da cadeia e das relações de cooperação e competição estabelecidas entre eles (SUZIGAN et al, 2000).

A proximidade geográfica e cultural é importante para as ações conjuntas estabelecidas no interior desses sistemas porque facilita a interação entre os produtores e acentua o processo de aprendizado. A interação entre os agentes reforça e amplia os benefícios incorporados pela empresa e promove o processo de aprendizado que ocorre no "âmbito interno à empresa, em virtude da elevada especialização dos produtores, e interno ao cluster, dadas as relações que as empresas mantém com outros agentes" (GARCIA, 2001, p. 43).

Os SLPs apresentam níveis distintos de especialização e firmas de tamanhos variados que implicam em possibilidade de incorporar várias técnicas de organização da produção entre as empresas e até mesmo numa mesma empresa, dependendo das tarefas executadas.

A heterogeneidade ao nível da empresa, de seu ambiente de atuação e, principalmente, das relações interempresas facilita a criação e incorporação de conhecimento-base similar ou complementar.

Além disso, a heterogeneidade pode reforçar as habilidades das empresas e dos segmentos na construção de conhecimento técnico ao longo da cadeia, resultando em ganhos econômicos para a região em que os Sistemas locais estão localizados. Por conta dessa natureza dinâmica e do elevado volume e variedade de produtos e empregos gerados nos SLPs, eles têm recebido significativa atenção de 
políticas públicas de desenvolvimento local e nacional nos últimos anos.

O caráter inovativo dos SLPs depende de características complementares entre si e que determinam o desempenho e a competitividade das empresas. Dentre essas características, merecem destaque a formação histórica e cultural dos indivíduos participantes dos SLPs, os níveis distintos de segmentação das etapas de produção, as economias externas de caráter incidentais e deliberadas, as técnicas e formas diferenciadas de aprendizado organizacional.

Para o propósito desta dissertação, serão analisadas nas seções seguintes duas das características dos Sistemas locais - a proximidade geográfica entre as empresas e as economias externas localizadas - considerando o papel atribuído à esses aspectos para o aprendizado inovativo das relações entre usuários e produtores.

De maneira geral, a literatura sobre Sistemas locais de Produção tem ressaltado que essas características estruturais são fundamentais para o seu desenvolvimento, as transações comerciais e o permanente aprendizado individual e coletivo das empresas de pequeno e médio porte ao longo da cadeia.

Contudo, o aprendizado organizacional e a criação e incorporação de melhorias em produtos e processos no interior dos SLPs só podem ser sustentados, no longo prazo, a partir da coordenação dos três componentes implícitos nas relações usuário-produtor - formação profissional e as competências dos indivíduos; trocas entre os departamentos; e ruptura e transformação de conceitos internos às empresas de máquinas.

\subsection{As características estruturais e o caráter inovativo dos SLPs}

O desenvolvimento e a evolução dos SLPs nas últimas décadas tornaram-se um fator importante para o desempenho e os ganhos econômicos de empresas e instituições nas economias industriais.

A organização em redes no nível local e até nacional (CASSIOLATO; LASTRES, 2001, p. 241) e a forma como as informações e os fluxos de conhecimentos são criados e organizados nesses SLPs possibilitam às empresas algumas vantagens na busca de rapidez no processo inovativo (CASSIOLATO; 
LASTRES, 2000, p. 238) e de novas oportunidades competitivas de longo prazo.

Entretanto, a principal contribuição da estrutura dos SLPs para o dinamismo industrial é que a organização em Sistemas locais de Produção determina a geração de economias externas incidentais que são apropriadas pelos agentes.

Além disso, os SLPs podem criar práticas de ações conjuntas deliberadas direcionadas à redução dos riscos de parada, à maior eficiência (SCHMITZ, 1998), ao processo de aprendizado local e à agregação de vantagens concorrenciais (GARCIA, 2001).

De acordo com Suzigan et al (2003), se entende por economias externas incidentais o benefício decorrente da existência local de conjunto de mão-de-obra especializada e de fornecedores de todos os elos da cadeia, bem como da presença de ambiente interno que incentiva a troca de informações sobre produtos e processos no Sistema Local de Produção.

As ações conjuntas, por sua vez, referem-se às estratégias de atuação que vão desde a compra conjunta de matéria-prima até o estabelecimento de mecanismos que facilitam o acesso a novas tecnologias e novos mercados (Suzigan et al, 2003). Nesse cenário, as empresas estão conectadas entre si através de uma rede de relações pessoais que reduzem consideravelmente as pressões externas (GRANOVETTER, 1985).

As economias externas são resultado da proximidade geográfica entre os agentes e do processo de especialização do território que cria um conjunto de trabalhadores capacitados, investimentos e atividades de apoio às empresas estabelecidas na região (BELLUSI, 2005, p. 6). Nesse sentido, as economias externas determinam a própria existência da aglomeração (SUZIGAN et al, 2003a) ${ }^{8}$ a partir da localização e aumento de empresas e instituições em todas as etapas da cadeia e de transbordamentos (spillovers) de conhecimentos e de tecnologia.

Os transbordamentos podem ocorrer através da maior mobilidade da mãode-obra e através de spin-offs de novas empresas, que surgem, inicialmente, como concorrentes diretas da empresa original, podendo atender um novo nicho de mercado ou tornar-se seus principais fornecedores (SCUR, 2006).

\footnotetext{
${ }^{8}$ Scur (2006) ressalta que embora a especialização possa ser responsável pelo aumento da eficiência dos processos produtivos da empresa, nem todas as economias de mão-de-obra e maquinário são decorrentes das grandes empresas, pois elas podem estar relacionadas ao volume de produção do ramo de atividade como um todo.
} 
Marshall (1920) ressalta três características principais das economias externas $^{9}$ :

a) Existência de amplo mercado local de mão-de-obra especializada;

b) Facilidades de acesso a fornecedores de matérias-primas, componentes, insumos e serviços especializados, e muitas vezes máquinas e equipamentos (SUZIGAN et al, 2003a). Neste ponto, Marshall (1920) aponta a existência de "profissões subsidiárias que fornecem à indústria principal os instrumentos e as matérias primas necessárias à organização de seu comércio e Ihe permitem meios de economia de material" (MARSHALL, 1920, p. 252); e

c) Maior disseminação local de conhecimento especializado que permite 0 rápido processo de aprendizado, criatividade e inovação (SUZIGAN et al, 2003a).

De maneira geral, o desenvolvimento dos Sistemas Locais de Produção é ancorado por especificidades históricas, institucionais, sociais e culturais das regiões em que as empresas estão estabelecidas e que possibilitam a criação de externalidades. Entretanto, outras características implícitas na organização dos SLPs contribuem para o aprendizado das empresas e condicionam o processo de inovação.

Bell e Albu (1999) apresentam uma proposta para explicar os diferentes patamares de inovação nos sistemas locais. Segundo os autores, as empresas no interior dos SLPs dispõem de três fontes de conhecimento: as atividades tecnológicas internas, as fontes externas e a formação de capital humano ao nível da empresa, e para incorporar tais fontes de inovação, são estabelecidos dois processos interdependentes: o sistema de produção e o sistema de conhecimento ${ }^{10}$.

Cabe ressaltar que o sistema de produção dos SLPs pode determinar a criação e difusão dos canais de informação, mas a mera existência dessa estrutura do tipo cluster $^{11}$ não fornece a explicação adequada para seu dinamismo

\footnotetext{
${ }^{9}$ Marshall (1920) estende essas vantagens aos benefícios para os consumidores, ao barateamento dos meios de comunicação e transporte e a possibilidade de induzir o desenvolvimento de outras regiões (MARSHALL, 1920, p. 255).

${ }^{10}$ O sistema de produção abrange o projeto de produtos, materiais, máquinas, insumos de trabalho e as relações de transação envolvidos na produção de bens. Já o sistema de conhecimento é constituído a partir do estoque de conhecimento interno à empresa e do fluxo de conhecimento demandado e empurrado por essa empresa.

${ }^{11}$ Bell e Albu (1999) denominaram as aglomerações de empresas de clusters, diferentemente da
} 
tecnológico. De fato, é a forma como os conhecimentos são criados e incorporados que pode definir o desempenho das empresas.

No sistema de conhecimento, o fluxo de informações pode ocorrer dentro das empresas, entre empresas no interior do sistema ou ainda em empresas de fora do sistema, sendo que todos esses tipos de fluxos podem contribuir para acumulação dos estoques de conhecimento e para as capacidades tecnológicas. E, à medida que os fluxos são transmitidos através dos canais estabelecidos entre os agentes, o aprendizado por interação e as melhorias em produtos e processos do setor podem ser intensificados.

O conhecimento interno à empresa é obtido a partir do monopólio de conhecimento-base, na forma de valores, rotinas e das experiências dos funcionários, e da socialização das informações entre os departamentos.

O desempenho distinto na realização das tarefas imprime pequenas diferenças a esse conhecimento interno que aumentam com o tempo, mesmo quando são partilhadas experiências comuns (MASKELL 2001; BATHELT et al, 2003). Além disso, há possibilidades de que ele se torne fragmentado em virtude das dificuldades em administrar os diferentes graus de competências (BATHELT et al, 2003);

Nas relações entre os departamentos, a comunicação entre os indivíduos de áreas distintas possibilita a combinação e recombinação continuada de recursos similares e não-similares para produzir novos conhecimentos (BATHELT et al, 2003), visando a realização do aprendizado interativo. Outro aspecto importante é que, freqüentemente, a criação de habilidades em estágios distintos e a sua utilização estão voltados a um propósito único e resultam em novos produtos ou em alterações nas propriedades técnicas do mesmo produto.

Bell e Albu (1999) ressaltam que o posicionamento das empresas no processo inovativo e sua dinâmica tecnológica podem ser explicados a partir da análise das características assumidas no processo de aquisição, criação e difusão de conhecimentos internos e externos aos SLPs:

a) Criação e aquisição de conhecimento - a fonte de conhecimento pode variar da baixa proporção - originária de fora do cluster - para alta proporção - resultante das relações no interior do SLP; 
b) Difusão e replicação de conhecimento - que pode ser mais ativa ou passiva, em situações nas quais a proximidade geográfica exerce papel mais forte ou nulo, respectivamente.

A base organizacional para a criação e aquisição de conhecimentos, por exemplo, pode ser fechada e indireta ou aberta e determinada, dependendo da relevância atribuída às fontes de conhecimento externas aos clusters. A base para a difusão de informações, por sua vez, pode ser mais ativa ou passiva, e difere consideravelmente entre os SLPs, em função do caráter cooperativo assumido pelas empresas.

Em grande parte dos SLPs, o dinamismo tecnológico é o resultado da interação entre o sistema de conhecimento - que incorpora as atividades intrínsecas à produção e os fluxos de informação puxados e empurrados pelo sistema - e o sistema de produção (BELL; ALBU,1999). Os sistemas mais dinâmicos apresentam a base organizacional para a difusão mais aberta e contam com fontes externas de conhecimento. Em contrapartida, os sistemas menos dinâmicos absorvem informações encravadas no ambiente interno aos SLPs. A partir dessa caracterização, Bell e Albu (1999) concluem que os SLPs podem apresentar um cenário de geração de competências bastante distinto conforme a relevância atribuída aos canais externos e internos de geração e aquisição do conhecimento (figura 3).

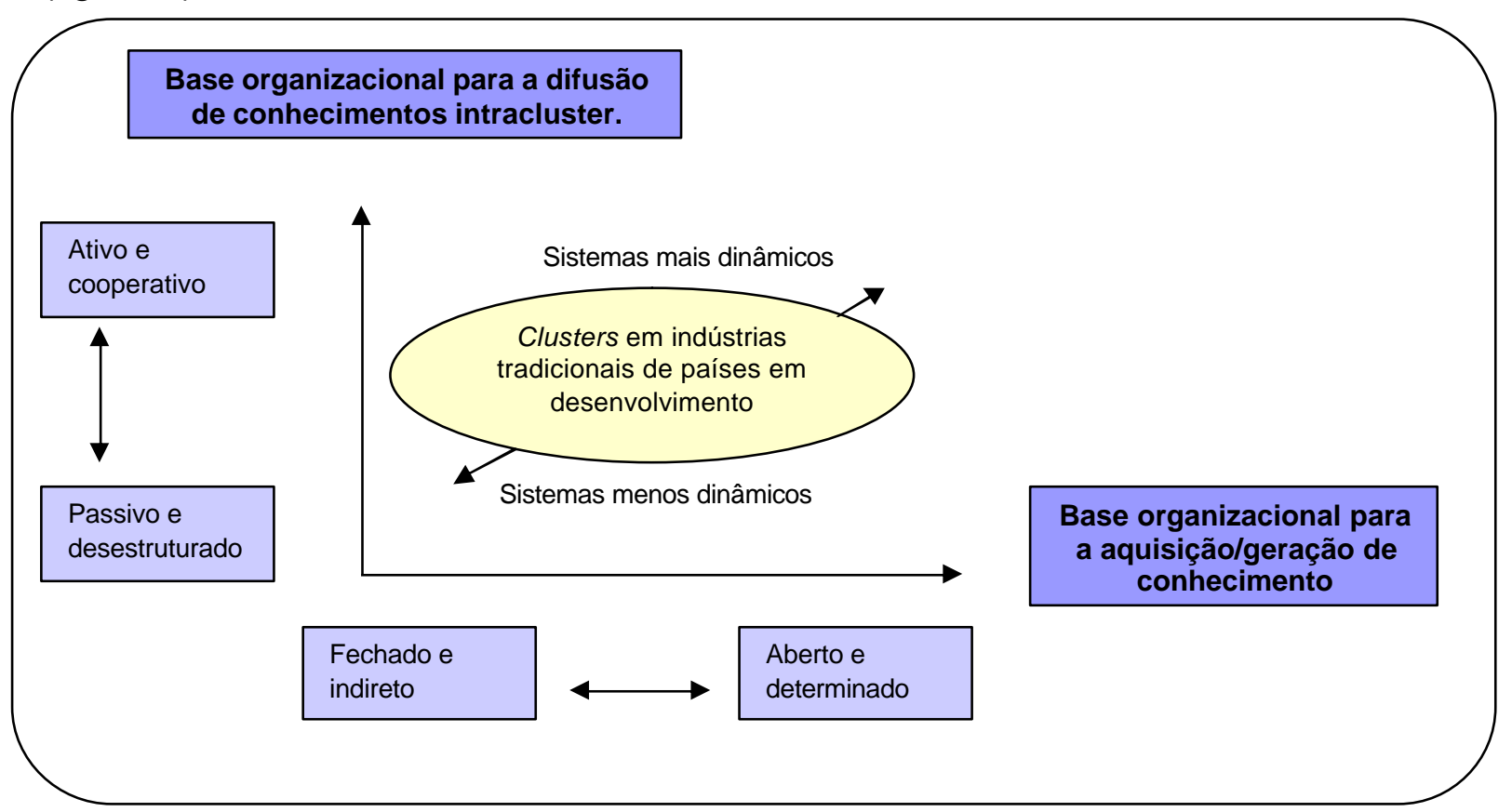

Fonte: Adaptado de BELL; ALBU, 1999, p. 1730.

Figura 3 - Sistema de conhecimento de empresas organizadas em clusters 
Outro fator importante para o processo de inovação nos Sistemas Locais é o seu contexto sócio-institucional (BATHELT et al, 2003). Uma vez desenvolvidas, as instituições interferem na incorporação dos benefícios oriundos dos SLPs e podem levar ao estabelecimento de ações conjuntas entre os agentes (SUZIGAN et al, 2003b, p.73).

Nesse sentido, as formas de governança, pública e privada (SUZIGAN et al, 2003b) estimulam o aprendizado de capacitações localizadas que são apropriadas por outras empresas e instituições e compartilhadas através de canais comuns de comunicação no interior do sistema local de produção (SUZIGAN et al, 2003a).

Um caso emblemático se dá quando as estratégias de um segmento do SLP são influenciadas pelos interesses de uma empresa líder, que direciona a atuação das demais empresas desse segmento.

Nessas situações, a governança local pode atenuar os efeitos negativos decorrentes da submissão aos interesses da empresa líder (SUZIGAN et al, 2003b), e pode acentuar ou reforçar as estratégias inovativas, possibilitando a continuidade das transações de mercado.

As estratégias de governança local e global têm passado por transformações significativas nos últimos anos, em virtude da diluição das fronteiras geográficas entre os atores participantes dos SLPs.

A dispersão geográfica de informações comuns às empresas dessas redes freqüentemente aumenta a distância cognitiva que elas devem superar nas estruturas de conhecimento (BATHELT et al, 2003), com implicações para o desempenho do conjunto do SLP.

A proximidade geográfica, por outro lado, facilita e reforça a proximidade epistemológica entre os indivíduos de um sistema local de produção porque a partir dessa proximidade, os indivíduos de uma comunidade criam e difundem as linguagens comuns entre si (BRESHI e LISSONI, 2001).

Os membros de uma comunidade estão reunidos não apenas por conta da identidade cultural e das obrigações recíprocas estabelecidas entre os demais indivíduos, mas porque o fluxo de informações técnicas e o compartilhamento de códigos éticos e culturais são muito mais intensos quando as empresas estão localizadas geograficamente próximas (BRESHI e LISSONI, 2001).

A governança nos SLPs tem fortalecido as vantagens competitivas das 
empresas em novos mercados por meio de incentivos e da coordenação dos vínculos entre a rede global e a local e, principalmente, a partir das políticas voltadas à exploração das oportunidades abertas às empresas localizadas geograficamente próximas.

Como resultado, as empresas têm desenvolvido novas habilidades para intensificar o aprendizado, a criatividade e a inovação nos Sistemas Locais (SUZIGAN, 2004, p. 5) a partir da realização de operações cotidianas das empresas.

As instituições públicas e privadas promovem a criação e aquisição desse conhecimento por meio da coordenação das interações entre as empresas, dos investimentos realizados no fortalecimento dos laços de confiança entre esses atores (BRESCHI; MALERBA, 2001).

Os órgãos governamentais, por exemplo, criam e orientam as instituições de apoio, ensino e de prestação de serviços e os usuários locais dessas informações. De outro, as associações de classe e organizações não governamentais podem atuar no fomento à competição e na promoção de ações conjuntas, funcionando como catalisadores do processo de desenvolvimento local (SUZIGAN et al, 2003b).

A proximidade geográfica e a identidade cultural entre empresas de várias etapas facilitam a atuação das instituições e interferem no desenvolvimento das empresas do sistema local de produção.

No SLP de calçados do Brasil, por exemplo, a dimensão de sistema não é explicada unicamente pelo tradicional fluxo comercial entre todos os segmentos e instituições que é realizado principalmente por conta da proximidade geográfica entre os agentes. A proximidade geográfica e cultural entre as empresas tem 0 potencial para fortalecer os vínculos ao longo das cadeias, repercutindo na forma como as empresas e instituições se relacionam e na maneira como elas incorporam e difundem informações de mercado, seja na definição conjunta de padrões de qualidade, na cooperação voltada à capacitação dos fornecedores, no treinamento de mão-de-obra, no aprendizado e difusão de inovações tecnológicas (NORONHA e TURCHI, 2002, p. 15) ou o estabelecimento de consórcios de compra e venda de produtos.

As duas características estruturais dos SLPS - proximidade geográfica e cultural - analisadas na próxima seção podem ser apontados como dinamizadores do desempenho interno ao SLP e como ativos que interfere na organização industrial e no aprendizado inovativo de toda a cadeia. 


\subsection{A proximidade geográfica nos SLPs e o processo de aprendizado interativo}

A proximidade geográfica e cultural entre os agentes do SLP é apontada como um fator importante para o aproveitamento de economias, para o aprendizado e para a disseminação de novos conhecimentos (SUZIGAN et al, 2003a) nas economias industriais.

O principal papel atribuído à proximidade geográfica entre empresas e instituições participantes de SLPs é que ela facilita a transmissão de novos conhecimentos, que se caracterizam como "complexos, de natureza tácita e específica a certas atividades de produção e inovação" (SUZIGAN, 2004, p.5).

Durante os estágios iniciais de projetos de pesquisa ou nas fases de descoberta de alguma tecnologia, por exemplo, grande parte do conhecimento terá que ser codificado e só poderá ser transmitido por meio de interações contínuas e de demonstrações práticas, facilitadas a partir da proximidade geográfica entre os indivíduos e empresas.

A literatura também tem ressaltado que essa proximidade geográfica proporciona economias de custos e o maior fluxo de informações entre as empresas. No primeiro, ela pode minimizar a necessidade de elevados estoques, eliminar os custos de transporte e possibilitar a redução dos preços dos serviços e produtos ofertados; enquanto o aumento do fluxo de informações, por sua vez, pode ocasionar a diminuição dos custos de transação, e ampliar as oportunidades para as soluções técnicas e a melhor compreensão de novas demandas.

Cabe ressaltar que a proximidade das empresas nos SLPs não é o único fator relevante para o seu desenvolvimento no longo prazo, mas é a partir desta proximidade que as empresas fortalecem as interações, a cooperação e o fluxo de conhecimentos entre etapas distintas da cadeia.

Alguns aspectos interligados à proximidade geográfica das empresas têm condições de determinar cenários distintos de aprendizado inovativo. Pode-se ressaltar que a identidade cultural entre os indivíduos, os relacionamentos de caráter horizontal e vertical e os mecanismos de coordenação dessas interações e dos fluxos de informações nos SLPs refletem significativamente no desempenho das empresas e sedimentam os benefícios decorrentes da proximidade geográfica entre os atores do SLP. 
Primeiramente, a unicidade de interesses e a identidade cultural entre os indivíduos participantes dos SLPs ampliam as condições para o aprendizado e para a troca de informações de mercado (BELLUSSI; GOTTARDI, 2000).

A identidade cultural e a formação histórica que determinam a união de empresas de um mesmo segmento, conjuntamente com a proximidade geográfica, facilitam o estabelecimento de níveis de confiança e de cooperação entre as empresas e como resultados reduzem a distância cognitiva entre os indivíduos.

Nas situações com menor distância cognitiva entre os indivíduos, por sua vez, os canais de comunicação são fortalecidos e as informações podem ser exploradas e melhoradas de maneira mais intensa, resultando na incorporação e difusão de conhecimento tecnológico.

A geração dos conhecimentos, nesse cenário, é delimitada por níveis distintos de incorporação de informações técnicas que se refletem em conhecimentos tácitos e que dependem da proximidade geográfica e cultural entre as empresas uma vez que é a partir dessa proximidade que elas têm condições de apreender novas técnicas e de ampliar suas oportunidades de mercado.

O segundo elemento inerente aos SLPs são os vínculos de caráter horizontal e vertical realizado ao longo da cadeia. BATHELT et al (2003) ressaltam que os SLPs fornecem oportunidades significativas para a transmissão de formas tácitas de conhecimento e que essas oportunidades se apresentam, freqüentemente, de maneira não articulada para as empresas

As relações horizontais e verticais entre as empresas dos SLPs possibilitam a organização da sua estrutura de produção, de logística e de comercialização de maneira diferenciada e determinam uma dinâmica particular de cooperação e concorrência voltado ao aprendizado inovativo para os segmentos a jusante e a montante (SUZIGAN et al, 2003).

O conhecimento tácito difundido no interior dos SLPs, por exemplo, difere da mera troca de informações sobre volumes, preços e características técnicas básicas e, quando associado às novas fontes de conhecimento codificadas, pode criar novos valores e estimular o crescimento das empresas no interior dessas organizações.

É importante destacar que nas relações horizontais, as empresas com atividades similares freqüentemente não cooperam na resolução de problemas técnicos, apenas interagem em alguns projetos específicos. A principal característica dessas relações é o seu aspecto concorrencial, que é explicado pelo grau de 
similaridade dos bens e das informações desenvolvidas entre as empresas dos SLPs (TIRONI, 2000). De maneira geral, essas empresas monitoram todas as suas funções de maneira fechada, sem esforços ou custos elevados, e contribuem muito pouco para as atividades inovativas do SLP (MASKELL, 2001). Os SLPs, por sua vez, mantêm-se em virtude das 'economias locacionais' provenientes da concentração geográfica.

As relações de caráter vertical, por outro lado, consistem em laços estabelecidos em diferentes etapas da produção e que apresentam elevado potencial cooperativo.

As empresas de etapas distintas concentram-se em algum processo particular em que são mais competitivas, e posteriormente investem mais na melhoria de suas capacitações por meio do processo learning-by-doing (MASKELL, 2001, p. 931).

Nas relações verticais estabelecidas entre usuários e produtores, por exemplo, as melhorias incorporadas pelos usuários são explicadas, principalmente, pelas mudanças incrementais realizadas constantemente pelos produtores de máquinas. Há uma significativa integração das atividades de pesquisas e desenvolvimento de produtos entre os usuários e produtores, que é responsável pelo aprendizado inovativo de ambos os lados e intensificam a criação de novas habilidades do lado dos produtores.

Nesse sentido, as empresas integradas verticalmente podem gerar a divisão de trabalho e a especialização das atividades, com efeitos significativos para o atendimento das exigências do mercado consumidor.

Um importante aspecto das relações verticais é que a cooperação nas transações entre as empresas depende dos laços de confiança desenvolvidos entre esses agentes e conta com a atuação de agentes institucionais locais (TIRONI, 2000). Nesse contexto, as instituições podem apresentar uma natureza mais geral e coordenar atividades aplicáveis para todos os SLPs, ou podem focar em questões mais específicas voltadas às empresas locais (MASKELL, 2001).

Segundo Brito (2004), a cooperação constitui uma alternativa para o processamento de informações e para "viabilizar a aglutinação de competências complementares" (BRITO, 2004, p. 2). Além disso, as práticas cooperativas permitem a integração de novas competências, o enfrentamento das flutuações econômicas e facilitam a identificação e o desenvolvimento de novas oportunidades tecnológicas. 
Em resumo, as práticas cooperativas e concorrenciais, desenvolvidas a partir das relações de caráter vertical e horizontal, respectivamente, refletem no processo de aprendizado no interior dos SLPs e no crescimento das empresas e dos segmentos articulados nesses aglomerados de empresas.

Para ilustrar como essas relações interferem, de fato, no aprendizado inovativo das empresas, pode-se explicar as etapas de criação, incorporação e difusão de conhecimentos dos SLPs a partir da adaptação do ciclo de internalização, socialização, combinação e externalização de conhecimentos apresentados por Nonaka e Takeuchi (1997).

$\mathrm{Na}$ fase de internalização, os conhecimentos apresentam um elevado caráter tácito porque dependem da repetição de rotinas e da experiência dos funcionários, fator esses que são específicos a cada departamento em cada empresa. Além disso, o domínio das capacidades internas é influenciado, em certo ponto, por escolhas passadas e por níveis distintos de acumulação de tecnologia de cada empresa.

O conhecimento internalizado apresenta pequenas diferenças individuais que aumentam com o tempo, mesmo quando são compartilhadas experiências em comum (BATHELT et al, 2003). Entretanto, as interações entre os funcionários de cada área com as outras etapas ou áreas de uma empresa permitem a socialização dos conceitos e dos fluxos de informações internalizados na etapa anterior.

Nesse sentido, a socialização do conhecimento entre os departamentos fornece as condições para a combinação e recombinação de habilidades de amplo alcance e de informações explícitas (e codificadas), a partir da atuação conjunta dos departamentos na concepção de novos produtos (BATHELT et al, 2003).

A realização dos fluxos de informações interna à empresa requer que esses agentes desenvolvam diferentes formatos de comunicação em um mesmo sistema, no contexto econômico e social como os papos, discussões, resolução de problemas, entre outros.

Os mecanismos de comunicação estabelecidos no interior dos SLPs não dependem de investimentos elevados visto que as empresas recebem as informações por estarem localizados nesses sistemas locais (BATHELT et al, 2003). Por este motivo, a natureza desses murmúrios (buzz) tende a ser espontânea e fluída em virtude das freqüentes reuniões pessoais e da comunicação informal de maneira não planejada (BATHELT et al, 2003).

Nesse contexto, os canais desenvolvidos no interior das empresas e por 
empresas de segmentos distintos podem constituir uma bnte de atualização, de resolução de problemas técnicos e de manutenção da vantagem competitiva das empresas, independente do seu grau de maturação tecnológica e de especialização.

$\mathrm{Na}$ fase seguinte - denominada por Nonaka e Takeuchi (1997) de externalização - o conhecimento combinado e melhorado a partir do contato com essas fontes de informação dos canais internos e externos às empresas é então apreendido pelos funcionários e é difundido (ou externalizado) para todos os departamentos da empresa. Nesse ponto, os conhecimentos externalizados podem ser inseridos ao sistema técnico e às estratégias globais da empresa.

Ao longo do tempo, as informações sobre processos e produtos externalizados para a empresa podem ser constantemente transformadas e aperfeiçoadas por meio de novos processos interativos estabelecidos entre os departamentos (BATHELT et al, 2003), repercutindo em outros ciclos de internalização, socialização, combinação e externalização dos conhecimentos.

Um aspecto importante para o ciclo é que a combinação das habilidades e das informações internas às empresas, assim como as capacitações requeridas nesse processo, pode ser intensificada quando a empresa estabelece relações horizontais ou verticais ao longo da cadeia.

As relações com fontes externas às empresas dos SLPs acentuam e fortalecem a troca de informações e o aprendizado inovativo, mas podem precisar de mecanismos de coordenação internos aos SLPs para surtir os efeitos esperados pelas empresas.

Essa incorporação de informações externas às empresas e aos SLPs, freqüentemente, pode ser coordenada por meio de duas estratégias - gatekeeper e per direta - que estão associadas às características principais das relações (horizontais ou verticais) desenvolvidas no interior de SLPs (AAGE, 2005).

Esses dois mecanismos voltados à aquisição de informações externas interferem de maneira distinta no desenvolvimento da capacidade de absorção interna das empresas e podem assumir contornos distintos em função das características das relações estabelecidas entre as empresas dos SLPs e de sua contribuição para a criação de capacitações (AAGE, 2005, p. 114), como pode ser observado no quadro a seguir (quadro 4). 


\begin{tabular}{|l|c|c|}
\hline $\begin{array}{c}\text { Características da dimensão } \\
\text { horizontal e vertical nos SLPs }\end{array}$ & Dimensão horizontal & Dimensão vertical \\
\hline Atividades e capacidades & Similar & Complementar \\
\hline Relações das empresas & Competidores & Insumo-Produto \\
\hline Modo de coordenação & Contato & Cooperação \\
\hline $\begin{array}{l}\text { Mecanismo de criação de } \\
\text { Conhecimento }\end{array}$ & Variação & $\begin{array}{c}\text { Especialização e aprendizado } \\
\text { interempresa }\end{array}$ \\
\hline Instituições & Regras e reputação & Confiança/Regras e reputação \\
\hline Conhecimento-base & Mesmo & Desigual \\
\hline
\end{tabular}

Fonte: AAGE, 2005, p. 115.

Quadro 4 - Características das relações horizontais e verticais em SLPs.

A estratégia "per direta" é comum às empresas que apresentam conhecimento-base semelhante e que desenvolvem atividades similares a partir de relações de caráter horizontal. Os indivíduos de cada empresa têm condições de acessar as informações externas e por esse motivo, há um fluxo maior de informações externas incorporadas pelo SLP, relativamente à estratégia gatekeeper (AAGE, 2005, p. 113).

A estratégia "gatekeeper", por outro lado, é voltada às empresas organizadas em SLPs que desenvolvem relações verticais e contam com estruturas de conhecimento especializadas locais. As empresas não têm mecanismos para acessar, isoladamente, o fluxo de informações no interior do SLP ou externas aos SLPs e, nesse sentido, requerem a atuação de intermediários (gatekeepers) para apreender melhorias incrementais ao seu processo produtivo.

A literatura sobre sistemas locais de produção, de maneira geral, tem enfatizado as relações verticais como forma de ampliar as oportunidades tecnológicas nos SLPs em virtude do seu caráter associativista e da cooperação sedimentada nas interações a jusante e a montante.

Entretanto, Aage (2005) considera que o caráter complementar das atividades, e a existência de conhecimentos base distintos nas relações verticais tendem a aumentar a distância cognitiva entre os indivíduos, e são uma justificativa para as dificuldades enfrentadas pelas empresas do SLP (AAGE, 2005) no acesso às informações externas.

Nesse sentido, os indivíduos intermediários no interior das empresas atuam num ambiente com elevado custo para acessar as informações e devem direcionar seus esforços para que os indivíduos e empresas participantes de SLPs possam 
incorporar, transformar e difundir as informações inovativas para os outros membros do SLP.

É importante ressaltar que a complementaridade das atividades e das capacidades desenvolvidas das relações verticais não dificulta 0 fluxo de informações, mas desencadeia o aprimoramento das funções interdepartamentais e a reorganização das atividades, resultando em melhorias de produto ou processo.

As relações usuário-produtor são emblemáticas da contribuição de relações verticais para o fortalecimento de capacidades entre empresas e interno aos departamentos de cada empresa no interior de SLPS.

Nos últimos anos, essas relações entre as empresas ampliaram a formação de redes de comunicação comuns nos SLPs e, desse modo, têm refletido na competitividade das empresas e no desempenho dos segmentos e dos SLPS.

De maneira geral, as relações entre diferentes elos da cadeia determinam a reorganização da estrutura de produção dos sistemas de forma mais eficiente, possibilitam a transmissão de informações sobre oportunidades tecnológicas e sobre as necessidades dos usuários (LUNDVALL, 1992) e integram diferentes áreas de conhecimento técnico (PROCHNICK, 2001) com conseqüentes inovações que podem ultrapassar o ambiente interno aos Sistemas locais de produção.

$\mathrm{Na}$ indústria brasileira de calçados, por exemplo, as relações estabelecidas entre os produtores de bens de capital e os seus usuários localizados em sistema local de produção são responsáveis por significativas melhorias nas competências e habilidades desenvolvidas no interior das empresas desse SLP.

É importante considerar que as estruturas de produção e oferta de todos os segmentos de máquinas e as políticas macroeconômicas das últimas décadas determinaram uma diversidade de situações e padrões de concorrência entre as empresas brasileiras de máquinas.

No segmento de máquinas para calçados, essa heterogeneidade foi reforçada pela natureza das fontes de inovação estabelecidas nos SLPS. As empresas de máquinas para calçado mantêm significativos contatos com seus usuários do sistema local de produção da cadeia calçadista e recorrem às empresas de máquinas e ferramentas do mercado interno e aos seus concorrentes do mercado externo (SILVA, 2003) para incorporar inovações de produtos.

Além disso, os produtores de máquinas têm contado com o incentivo de instituições públicas e privadas, que direcionam as estratégias competitivas das 
empresas e a sua inserção em outros mercados, a partir da maior participação dos produtores em feiras e eventos do mercado externo.

Do lado das empresas de calçados, a variedade dos produtos, os requerimentos tecnológicos distintos e a sazonalidade da demanda, entre outros fatores, determinaram o desenvolvimento de empresas com portes e capacitações distintas e estruturas de governança complexas, que imprimem elevado dinamismo às redes de relacionamentos com outras empresas e segmentos da cadeia calçadista.

Esses aspectos da dinâmica industrial do setor de bens de capital e, particularmente, das relações entre as empresas de máquinas para calçados e seus usuários são fundamentais para o seu desempenho em mercados distintos e para o desenvolvimento industrial e tecnológico do setor de calçados.

Os vínculos e parcerias estabelecidos ao longo da cadeia calçadista são relevantes para o fortalecimento das capacidades dinâmicas internas às empresas e podem promover a difusão de melhorias para o SLP. Entretanto, os investimentos na formação técnica dos funcionários, as interações entre os departamentos e o processo de revisão e transformação permanente dos conceitos e habilidades, incorporados internamente pelos funcionários, podem variar muito de uma empresa de máquinas para outra, por conta dos vínculos estabelecidos entre empresas. Nesse sentido, o desenvolvimento dessas capacidades dinâmicas depende, fundamentalmente, do ambiente em que as empresas de máquinas estão inseridas.

O desenvolvimento e a organização industrial e produtiva da indústria de bens de capital e do segmento de máquinas para calçados - apresentados no próximo capítulo - levantam alguns aspectos que podem ajudar a compreender a dinâmica das empresas de máquinas para calçados e de suas relações com os usuários da cadeia calçadista. 


\section{A indústria de bens de capital no Brasil}

A evolução e o desempenho da indústria de bens de capital são importantes para a estrutura industrial do país porque as empresas de máquinas têm condições de ampliar a capacidade da economia para crescer e podem viabilizar o aumento da produtividade de vários segmentos. Outro fator relevante é que a indústria de bens de capital pode acelerar o processo de difusão de inovações: como incorpora tecnologias de usuários e fornecedores, a máquina é portadora de conhecimento para todos os setores da indústria (NERLMUM, 2003, p. 1), e nesse sentido, pode definir a competitividade das empresas a montante e a jusante.

O que define um produto como bem de capital é "a sua utilização em contínuos processos produtivos de outros bens e serviços, sem que sofra transformação, como ocorre com os insumos" (ALEM; PESSOA, 2005, p. 75).

Na taxonomia sobre a produção e difusão de inovações de Pavitt (1984), a indústria de bens de capital é classificada como fornecedora especializada de máquinas e equipamentos para outros setores industriais. A trajetória tecnológica do setor é determinada por empresas relativamente pequenas, que têm como principal fonte de tecnologia para o projeto e desenvolvimento de novos produtos a interação com os seus usuários ${ }^{12}$. Além disso, a inovação relativamente predominante do setor é a inovação de produto, obtida a partir do desenvolvimento de projetos e de melhorias em conjunto com seus clientes (PAVITT, 1984).

O desenvolvimento da indústria de bens de capital está atrelado às características das empresas a montante - como a formação histórica dos ramos industriais até os níveis distintos de desenvolvimento técnico no curto e longo prazo - e o grau de desenvolvimento das empresas a jusante (AVELLAR, 2004). Além disso, os segmentos têm apresentado graus distintos de concorrência com empresas estrangeiras, o que se reflete no seu desempenho industrial e tecnológico.

A literatura tem apontado que em virtude da sua posição estratégica para a economia, a produção de bens de capital deve ocorrer de tal forma a não comprometer o desenvolvimento econômico. No cenário comercial, a produção interna dos segmentos de bens de capital de várias categorias tecnológicas é um

$\overline{12}$ Outras informações sobre o padrão de inovação da indústria de bens de capital podem ser 
mecanismo relevante para restringir as importações e limitar a dependência do país em momentos de restrição externa ao crescimento (VERMULM, 2003).

Entretanto, o país tem apresentado um conjunto de modificações no cenário econômico e industrial que estão subordinadas à macroeconomia, na medida em que depende das taxas de investimento do país e das expectativas quanto ao crescimento da demanda interna (VERMULM, 1996).

Adicionalmente, a inter-relação estabelecida com outros segmentos industriais pode conferir às empresas de máquinas uma diversidade de situações que limitam o seu desenvolvimento, visto que elas operam em ambientes competitivos heterogêneos, cada qual com um padrão de concorrência ${ }^{13}$ (DUARTE, 2001; KUPFER, 1998).

Esses aspectos atuam sobre a organização do setor - tornando os segmentos heterogêneos em várias dimensões - e em sua capacidade para desenvolver e incorporar inovações tecnológicas, reforçando a competitividade cíclica do setor e suas deficiências na esfera comercial, produtiva e tecnológica.

\subsection{A organização industrial e produtiva da indústria de bens de capital}

A indústria de bens de capital apresenta uma estrutura bastante diversificada em termos de porte e número de empresas, número de segmentos, grau de capacidade instalada, número de funcionários, entre outros. Atualmente, $23 \%$ das empresas em todos os segmentos de bens de capital são de pequeno porte, $70 \%$ de médio e $7 \%$ são grandes.

A Classificação Nacional de Atividade Econômica (CNAE) identifica um total de seis grupos participantes da indústria de máquinas e equipamentos (capítulo 28): Fabricação de motores, bombas, compressores e equipamentos de transmissão

\footnotetext{
observadas mais adiante.

${ }^{13}$ Vale ressaltar que neste trabalho será utilizada a definição de Kupfer (1998) sobre padrão de concorrência como "conjunto particular de formas possíveis de concorrência que predomina em um dado espaço de competição econômica (mercado ou indústria, região, nação) por um período de tempo tal que (as empresas buscariam adotar, em cada instante, estratégias - investimentos inovação, marketing, produção, etc) voltadas para capacitá-las a concorrer por preço, esforço de venda, diferenciação de produto, etc, compatíveis com o padrão de concorrência setorial" (KUPFER, 1998, p. 31-32).
} 
(grupo 28.1); Fabricação de máquinas e equipamentos de uso geral (grupo 28.2); Fabricação de tratores e de máquinas e equipamentos para a agricultura e pecuária (grupo 28.3); Fabricação de máquinas-ferramentas (grupo 28.4); Fabricação de máquinas e equipamentos de uso na extração mineral e construção (grupo 28.5); e Fabricação de máquinas e equipamentos de uso industrial específico (grupo 28.6) ${ }^{14}$.

Os segmentos mais avançados tecnologicamente são os de máquinasferramenta, as agrícolas, as máquinas para corte de madeira e as de máquinas para alimentos (SETOR DE MÁQUINAS MOVIMENTA..., 09/10/2006). Os segmentos com tecnologias mais simples, por sua vez, são constituídos predominantemente por empresas de pequeno e médio porte que desenvolvem máquinas para empresas intensivas em mão-de-obra, e que utilizam pouco os recursos microeletrônicos e tecnológicos na fabricação de seus produtos.

O desempenho da indústria pode ser avaliado a partir do seu faturamento nominal e nível de utilização da capacidade instalada (apresentados na tabela 1), principalmente nos segmentos de bens de capital mecânico, que abrangem parcela expressiva dos bens de capital seriados (VERMULM, 2003, p. 10).

Tabela 1 - Indicadores de desempenho do setor de máquinas e equipamentos mecânicos.

\begin{tabular}{|c|c|c|c|c|c|c|c|}
\hline Discriminação & 2001 & 2002 & 2003 & 2004 & 2005 & 2006 & $\begin{array}{c}\text { Variação } \\
2006 / 05 \\
(\%)\end{array}$ \\
\hline Faturamento $N$ & 30.237 & 34.163 & 35.100 & 47.210 & 55.862 & 54.822 & 18,3 \\
\hline Número de Empregos (Mil) * & 175 & 175 & 183 & 207 & 212 & 209 & 2,4 \\
\hline Nível médio de utiliz.da cap. inst.(\%) & 77 & 78 & 77 & 82 & 81 & 80 & $-1,1$ \\
\hline Investimentos (R \$ Milhões) & 2.470 & 4.457 & 4.233 & 6.101 & 6.186 & 6.893 & 1,4 \\
\hline
\end{tabular}

Fonte: ABIMAQ/SINDIMAQ, disponível em IBGE (2007a).

${ }^{*}$ ) Final do período.

Um aspecto relevante para explicar a estrutura do setor de bens de capital é a instabilidade cíclica da demanda por máquinas nos períodos de recessão ou prosperidade econômica, uma vez que o desempenho do setor varia muito em função das flutuações no contexto macroeconômico e de seus efeitos sobre o nível geral de investimentos da economia.

O caráter cíclico da demanda por máquinas é condicionado pelos elementos que compõem a demanda do setor: demandas destinadas à reposição ou à ampliação da capacidade produtiva.

\footnotetext{
14 Informações mais detalhadas sobre a Classificação de Atividade econômica (CNAE) para os setores de bens de capital podem ser consultadas no Anexo 1 deste documento .
} 
No primeiro grupo, o que determina a demanda por máquinas é o tempo de vida útil das máquinas, equipamentos e instalações que formam a estrutura produtiva, e o ritmo de inovações no processo produtivo do setor (DUARTE, 2001, p. 35). Como a demanda de máquinas refere-se à capacidade já instalada que as empresas buscam pelo menos manter, a demanda para reposição tende a ser mais estável do que a demanda destinada à expansão da capacidade instalada (DUARTE, 2001). Além disso, as máquinas para reposição são responsáveis por empurrar as melhorias em produtos e processos para os usuários à medida que as máquinas vão se tornando física e tecnologicamente obsoletas (AVELLAR, 2004), o que determina o ritmo de inovação dos setores de máquinas ${ }^{15}$.

As empresas de máquinas destinadas à ampliação da capacidade produtiva, por sua vez, dependem do grau de capacidade ociosa presente, da taxa de crescimento da indústria e das expectativas de lucro e de demanda (AVELLAR, 2004). E qualquer variação nesses fatores refletirá diretamente nos investimentos voltados ao dimensionamento da produção e às estratégias inovativas do setor no longo prazo.

Nos períodos de recessão econômica, por exemplo, a expectativa é de que a capacidade instalada seja mais do que suficiente para atender à demanda por máquinas, e por esse motivo, o investimento destinado à expansão da capacidade tende a cair. Da mesma forma, as demandas para reposição de bens de capital podem ser adiadas em virtude das incertezas e da necessidade em manter recursos disponíveis para enfrentar momentos de restrição financeira (DUARTE, 2001, p. 36).

Nos períodos de prosperidade, por outro lado, a indústria de bens de capital precisa responder rapidamente à demanda por reposição de máquinas e à ampliação da capacidade produtiva instalada. Além disso, o setor atende à demanda para suas próprias empresas, que necessitam não apenas repor seus bens de capital, como se expandir para dar conta da demanda do resto da economia.

Por conta desses fatores, a indústria de bens de capital é a primeira a reduzir as atividades nos períodos de baixo investimento, e a última a acelerar o ritmo de produção nos períodos de aquecimento econômico, apresentando uma dimensão relativamente maior do que nos outros setores da economia (DUARTE, 2001;

\footnotetext{
${ }^{15}$ Cabe ressaltar que as empresas de máquinas não dependem exclusivamente do surgimento dessas necessidades para apresentar novos produtos ou melhorias técnicas para os seus usuários.
} 
VERMULM, 2003).

Em ambos os períodos, as flutuações das taxas de investimento tendem a determinar um comportamento elasticamente pró-cíclico do setor, que reflete $\mathrm{m}$ nível de utilização da capacidade instalada da indústria e na formação distinta dos ramos industriais de máquinas.

A adversidade de situações e a heterogeneidade do setor de máquinas e equipamentos podem ser compreendidas a partir de três dimensões: estrutura produtiva; a estrutura de oferta (organização e porte das empresas); e os mecanismos de desenvolvimento tecnológico - diretamente relacionadas ao ritmo tecnológico do segmento e que interferem no seu perfil de criação e difusão de tecnologias (ERBER; DUARTE, 2002; AVELLAR, 2004).

A primeira dimensão é a estrutura produtiva dos segmentos que compõem a indústria brasileira de bens de capital.

As empresas de máquinas podem ser classificadas segundo a finalidade a que se destinam os seus produtos: as empresas fornecedoras de máquinas de mesmo segmento realizam distintos tipos de trabalhos como, por exemplo, máquinas para tornear, retificar e conformar materiais metálicos visando 0 atendimento daquelas demandas (DUARTE, 2003, p. 5) ${ }^{16}$

Os segmentos da indústria de bens de capital, por sua vez, podem ser classificados a partir das especificidades técnicas - a forma como os produtos são concebidos: produção em série ou sob encomenda.

O segmento de bens seriados agrega produtos fabricados em larga escala (ALEM; PESSOA, 2005, p. 75), com relativa padronização de projeto, já que há pouco espaço para alterações do produto ou processo e as empresas apresentam economias estáticas de produção. As empresas tendem a operar com maquinário especializado e processos relativamente rígidos. Além disso, as competências e os recursos requeridos na comercialização e serviços pós-venda, freqüentemente, são realizados por terceiros.

$\mathrm{Na}$ produção sob encomenda, por sua vez, os produtos são concebidos segundo características técnicas associadas a um determinado processo produtivo (ALEM; PESSOA, 2005, p. 75). A produção geralmente abrange equipamentos tecnologicamente sofisticados e que atendem pedidos muito específicos dos

${ }^{16}$ Outros pontos que diferenciam empresas com a mesma finalidade produtiva são desempenho, 
usuários, o que justifica o forte envolvimento entre o fabricante e o usuário na etapa de projeto dos equipamentos (PASSOS, 1998; ALEM; PESSOA, 2005). Além disso, a estrutura produtiva para esses grupos de produtos requer a flexibilidade dos equipamentos, da mão-de-obra e das rotinas internas às empresas.

Como a produção se desenvolve a partir da repetição de experiências em projetar e fabricar bens com características semelhantes, as empresas que trabalham sob encomenda apresentam economias dinâmicas de produção (ERBER; VERMULM, 2002; VERMULM, 2003, p. 6).

Outra distinção entre os segmentos de bens de capital seriados e sob encomenda é que, no primeiro, as empresas dependem da escala de produção; enquanto os segmentos com produção sob encomenda dependem da tecnologia de produto $^{17}$.

A segunda dimensão responsável pela heterogeneidade da indústria de bens de capital são as estruturas de oferta relativamente distintas de um segmento para outro. Os segmentos apresentam graus variados de barreiras à entrada e empresas produtoras de bens de capital com portes distintos, fatores estes que estão diretamente relacionados às características dos produtos projetados e fabricados e aos níveis distintos de capacitação no desenvolvimento dos ativos tangíveis e intangíveis.

No Brasil, a estrutura industrial do setor de máquinas e equipamentos é formada, principalmente, por segmentos de mercado com predomínio de empresas de pequeno e médio porte (geralmente familiares), que produzem bens seriados de baixa sofisticação tecnológica e grandes empresas multinacionais (ALEM; PESSOA, 2005, p. 75; VERMULM, 2003, p. 6).

As empresas de pequeno e médio porte dos segmentos de bens de capital seriados utilizam tecnologias mais maduras e enfrentam mais limitações para investimentos permanentes em pesquisa e desenvolvimento. Por esse motivo, esses segmentos seriados apresentam reduzidas barreiras à entrada de novos

\footnotetext{
flexibilidade, produtividade, precisão, preço, sofisticação tecnológica (VERMULM, 2003).

17 Para se ter uma idéia da heterogeneidade do setor, pode-se destacar as classificações utilizadas para ordenar a finalidade produtiva das empresas, a partir da Classificação de Atividade Econômica CNAE. Na área comercial, merece atenção a classificação da Nomenclatura Comum do Mercosul, organizada pela Secretaria do Comércio Exterior (SECEX) em conjunto com as secretarias de comércio de outros países, como forma de padronizar as denominações dos produtos transacionados internacionalmente. As classificações completas do Mercosul para indústria de máquinas estão apresentadas no Anexo 1.
} 
concorrentes.

Os segmentos com produção sob encomenda, por outro lado, contam com a participação de empresas multinacionais e detêm elevadas barreiras à entrada, justificadas por conta dos custos, da diferenciação de produtos ou do grau de desenvolvimento tecnológico dos setores (VERMULM, 2003; ALEM; PESSOA, 2005, p. 76).

As empresas de máquinas seriadas e sob encomenda têm apresentado elevado índice de verticalização da produção por conta da necessidade de fornecimento de peças, componentes e partes - dado o cenário de precariedade da base produtiva de fornecedores. Adicionalmente, as flutuações do mercado interno têm dificultado o desenvolvimento de suas capacidades internas (RESENDE; ANDERSON, 1999). Neste contexto, elas concentram suas atividades nas tarefas em que reúnem bons conhecimentos técnicos e experiência, verticalizando as demais atividades produtivas e não-produtivas.

A última dimensão relevante para entender a formação heterogênea da indústria de bens de capital é o nível de capacitação e os mecanismos desenvolvimento tecnológico das empresas de cada segmento da indústria.

A incorporação de tecnologias de base microeletrônica e a inserção de outros países na produção mundial de máquinas têm condicionado o desempenho das empresas brasileiras de máquinas. Mas a competitividade dos produtores de máquinas reflete as características e as condições dadas pelo mercado e têm variado muito em função dos mecanismos de aprendizado tecnológico de cada segmento e dos ativos e rotinas desenvolvidas em cada empresa para o seu desenvolvimento tecnológico.

As empresas de máquinas recorrem a vários mecanismos para o aprendizado tecnológico e detém competências distintas, o que pode intensificar a criação de competências em projetos e produtos. A principal fonte de aprendizado do segmento de bens de capital mecânico, por exemplo, é a adaptação de máquinas e equipamentos para a produção local - engenharia reversa - (AVELLAR, 2004, p. 3), mas os segmentos de máquinas também recorrem ao licenciamento de tecnologias importadas; aos contatos com usuários dos mercados interno e externo; e às pesquisas em escritório de P\&D das empresas multinacionais, entre outros 
mecanismos.

Além disso, como os produtos e processos são muito diversos, as rotinas e os ativos envolvidos na produção e as competências requeridas para a competitividade das empresas podem variar muito de uma empresa para outra e entre os segmentos.

O cenário macroeconômico, a diversidade dos mecanismos de aprendizado e os ativos e competências envolvidos na produção interferem na estratégia industrial, no desenvolvimento de inovações e na dinâmica de capacitação tecnológica das empresas de máquinas, fornecendo condições atípicas para o desenvolvimento entre os segmentos de máquinas como poderá ser analisado nas próximas páginas.

\subsection{Panorama da indústria brasileira de bens de capital}

A organização e a heterogeneidade das empresas brasileiras de bens de capital - em termos de estrutura produtiva, estrutura de mercado e desenvolvimento tecnológico - são influenciadas por uma série de fatores do contexto macroeconômico e tecnológico e da capacitação das empresas, que podem dificultar ou intensificar o seu desempenho nos mercados interno e externo.

Os fatores condicionantes do desempenho das empresas de máquinas do mercado nacional são principalmente as políticas econômicas aplicadas desde os anos 80; as mudanças do paradigma tecnológico ocorridas mundialmente; e a concorrência internacional, principalmente com os países asiáticos como a China.

O cenário macroeconômico interfere nas expectativas empresariais do mercado interno ou nas expectativas dos investidores de empresas localizas no exterior (VERMULM, 2003), refletindo-se no desenvolvimento industrial do setor de máquinas.

A instabilidade em relação à política econômica ou à regulamentação dos mercados pode gerar incertezas quanto ao futuro e determinam variações nas taxas de investimento no mercado interno de bens de capital porque as empresas não vêem o retorno de seus planos de investimento no longo prazo (VERMULM, 2003, p. 2), o que justifica o caráter pró-cíclico de bens de capital.

Nos períodos em que a demanda está aquecida, as empresas de bens de 
capital ampliam a capacidade produtiva e podem até investir em novas máquinas ou na modernização, otimizando sua estrutura produtiva. Já nos períodos de demanda desaquecida, as empresas tendem a apresentar baixa utilização de capacidade produtiva (AVELLAR, 2004; VERMULM, 2003)

A característica pró-cíclica da produção de bens de capital pode ser caracterizada em três períodos (anos 70; década de 80; e o período pós-1990), nos quais os aspectos macroeconômicos e de dinâmica de mercado repercutiram na organização e o desempenho dos segmentos de bens de capital.

No período entre os anos 70 e início dos anos 80, o país enfrentou, de um lado, alterações na política econômica que refletiram sobre a competitividade de todos os setores industriais; e de outro lado, o aparecimento de novas tecnologias com base microeletrônica, que promoveram mudanças graduais nas capacitações dos setores produtores e usuários de máquinas.

Nos anos 70, a economia nacional apresentava um cenário de crescimento do PIB e elevados investimentos que contrastavam com uma conjuntura interna de instabilidade e que não favorecia o desenvolvimento tecnológico do setor de máquinas (VERMULM, 2003) ${ }^{18}$. Nessa conjuntura, as empresas dispunham de subsídios fiscais e financeiros e ampla proteção no mercado interno que resultaram em sobreinvestimento e em baixa eficiência econômica (VERMULM, 2003).

A indústria de máquinas já se consolidara como fornecedora de máquinas e ferramentas para o mercado nacional, principalmente no segmento de máquinas convencionais (VERMULM, 2003; ALEM; PESSOA, 2005). Entretanto, a instabilidade da demanda no mercado interno limitava a realização de investimentos em programas de capacitação tecnológica interna, e representa va um entrave para o desenvolvimento das empresas de máquinas no longo prazo.

Além disso, o processo de substituição de importações no final dos anos 70 refletiu em deficiências estruturais no desenvolvimento da indústria brasileira em termos de preços, inovação e diferenciação de produtos. Vários segmentos se apoiavam nas importações de maior conteúdo tecnológico como recurso para superar ou atenuar as limitações tecnológicas (RESENDE; TEIXEIRA, 2001, p. 22).

Já nos anos 80, a taxa de investimento apresentava tendência de queda, e nesse cenário, a produção industrial da economia como um todo apresentou baixo

${ }^{18} \mathrm{O}$ período é caracterizado pelo superdimensionamento dos investimentos visando o atendimento 
crescimento (VERMULM, 2003). Entretanto, nos segmentos de bens de capital mecânicos, por exemplo, a forte retração da demanda interna foi amenizada, em parte, pela difusão do paradigma da eletrônica integrada à mecânica NERMULM, 2003, p. 11) que estava em seu auge nos países desenvolvidos.

\section{A convergência entre a base técnica metal-mecânica e a eletrônica} mudou o processo de concepção e fabricação das máquinas e os recursos tecnológicos para manuseio das máquinas, com a incorporação de dispositivos de controle numérico computadorizado que aumentaram a flexibilidade e produtividade no uso destas máquinas (PASSOS, 1998; VERMULM, 2003).

Nesse cenário, as empresas de máquinas ampliaram o seu leque de ativos e competências internas para se adaptar à inserção de controles eletrônicos (e seu software) e de novos materiais já que esses mecanismos alteraram as formas de projetar, fabricar, vender e dar assistência aos seus clientes (ERBER; VERMULM, 2002).

O ambiente macroeconômico inibiu os investimentos e, conseqüentemente limitou a difusão de melhorias tecnológicas em algumas empresas; enquanto outras empresas foram forçadas a investir na automação eletrônica de seus respectivos processos de produção para atender ao mercado externo, uma vez que a demanda interna estava retraída (VERMULM, 1996) ${ }^{19}$.

No segmento de máquinas-ferramentas, Vermulm (1996) destaca três grupos de empresas que atuavam nos anos 80: líderes, caudatárias e de sobrevivência passiva ${ }^{20}$. Dentre esses grupos, somente as empresas líderes apresentavam conhecimentos técnicos provenientes da difusão tecnológica passadas, tinham tradição em realizar atividades tecnológicas, inclusive em tecnologia eletrônica, e dispunham de informações sobre as tecnologias do mercado internacional (PASSOS, 1998; VERMULM, 1996, p. 85).

\footnotetext{
da elevada demanda em infra-estrutura.

${ }^{19}$ As dificuldades enfrentadas na adoção do paradigma microeletrônico são aspectos fundamentais para explicar a heterogeneidade no interior da indústria de bens de capital, visto que mesmo as empresas de máquinas-ferramentas com estratégias líderes conviviam com duas bases técnicas distintas - muitas delas produziam máquinas convencionais e de comando numérico NERMULM, 1996, p. 86).

${ }^{20}$ As empresas líderes promoveram mudanças técnicas nos produtos e principalmente nos seus processos produtivos, articulando saltos tecnológicos para todo o segmento. As caudatárias estavam condicionadas pela demanda e tentaram avanços em tecnologias de produto, poucas com sucesso, somente quando o cenário econômico voltou a crescer. Por último, as empresas com estratégias de sobrevivência passiva estavam totalmente condicionadas pelo mercado e investiram muito pouco em tecnologias de produto e processo (VERMULM, 1996, p. 85).
} 
As empresas que investiam em tecnologias já apresentavam boa capacitação técnica e, por este motivo, apresentavam grande parte das capacitações para adaptar-se às mudanças do paradigma tecnológico no mercado internacional e se beneficiar do potencial de crescimento mais animador em outros mercados (PASSOS, 1998; VERMULM, 2003, p. 11). Em alguns segmentos de máquinas do mercado interno, as assimetrias geradas com a incorporação das mudanças tecnológicas foram mais acentuadas do que nos países desenvolvidos (PASSOS, 1998, p. 28) ${ }^{21}$.

A partir dos anos 90, o país apresentou uma pequena retomada do crescimento no mercado interno e do consumo, decorrente da estabilização da moeda. Adicionalmente, recorreu-se à abertura da economia ao comércio internacional e a algumas medidas de cunho fiscal e monetário para reverter a baixa eficiência produtiva herdada das décadas passadas, que repercutiram nas condições macroeconômicas do país e na competitividade das empresas de máquinas e equipamentos (RESENDE; ANDERSON, 1999; VERMULM, 2003; ALEM; PESSOA, 2005).

Outra medida com impacto relevante para o setor foi a eliminação de restrições não-tarifárias às importações e a redução de alíquotas dos impostos de importação que incentivaram as importações de máquinas e equipamentos e favoreceram a substituição de equipamentos nacionais por estrangeiros (VERMULM, 1996, 2003).

O mercado interno ficou mais retraído e competitivo em virtude da redução das barreiras às importações. E, nesse momento, não havia mais a alternativa de investir em outros segmentos de mercado, visto que microeletrônica já havia se consolidado entre as empresas do mercado interno e externo.

Para enfrentar a concorrência externa, as empresas que apresentavam condições tecnológicas e preços competitivos passaram a operar em níveis próximos da plena capacidade, e mesmo com o crescimento muito instável do mercado interno, elas não realizaram investimentos para ajustar o ritmo de produção de bens de capital à demanda.

Para atenuar a situação, muitas delas realizaram a reestruturação produtiva e

\footnotetext{
${ }^{21}$ No segmento de máquinas-ferramentas, por exemplo, mesmo a difusão de inovações entre as principais empresas não resultou em alterações profundas na estrutura industrial deste segmento, como ocorreu no Japão e outros paises desenvolvidos (PASSOS, 1998, p. 29).
} 
organizacional; enquanto outra parte das empresas de pequeno e médio porte encerrou suas atividades.

De maneira geral, os segmentos de máquinas e equipamentos promoveram a reestruturação da produção, recorrendo à focalização dos negócios ou à redução da diversificação de seus produtos. Em muitos casos, as empresas desverticalizaram a produção, programaram mudanças na produtividade e qualidade e promoveram inovações em gestão, visando o aumento da eficiência produtiva e a adequação às condições exigidas pelo mercado.

No cenário de queda dos investimentos, muitas empresas de máquinas permaneceram no mercado, porém desativaram parte de suas atividades locais, optando por: montagem de kits adquiridos com base em acordos de tecnologia; especialização em nichos de mercado, com a redefinição drástica de suas linhas de produtos; e realização de acordos de cooperação e joint-ventures internacionais (CAFÉ et al, 2004, p. 226).

Com essas transformações, a indústria de bens de capital pôde aumentar a eficiência do aparelho produtivo e reduzir os custos, sem a necessidade de realizar grandes investimentos em máquinas e equipamentos (VERMULM, 2003, p. 12). Nesse sentido, as flutuações da economia brasileira e o aumento da eficiência do aparelho produtivo atuaram ainda mais na retração da demanda interna por bens de capital e no aumento da especialização produtiva do setor (ALEM; PESSOA, 2005).

Nos últimos anos da década de 90 e nos primeiros anos deste século, por exemplo, o crescimento do PIB refletiu em baixa taxa de investimento na modernização da economia brasileira e em mais retração da demanda por máquinas (VERMULM, 2003; ALEM; PESSOA, 2005, p. 80).

Como conseqüência, a formação bruta de capital fixo (FBCF) que indica se a capacidade de produção do país está crescendo, tem apresentado uma variação anual relativamente maior que a variação do PIB, o que pode ser um indicador do caráter elasticamente pró-cíclico da demanda de bens de capital, como podem ser observados na tabela 2 e na figura 4 apresentados a seguir. 
Tabela 2 - Produto Interno Bruto e Formação Bruta de Capital Fixo.

\begin{tabular}{cccccccc}
\hline Ano & \multicolumn{2}{c}{ Milhões de R\$ } & \multicolumn{2}{c}{ Taxa de Investimento } \\
(FBCF / PIB) \% & \multicolumn{2}{c}{ Variação Real Anual (\%) } \\
& PIB & FBCF & $\begin{array}{c}\text { Preços } \\
\text { Correntes }\end{array}$ & $\begin{array}{c}\text { Preços do } \\
\text { Ano } \\
\text { Anterior }\end{array}$ & PIB & FBCF & $\begin{array}{c}\text { PIB Per } \\
\text { Capita }\end{array}$ \\
\hline 1997 & 939.147 & 163.134 & 17,4 & 17,7 & 3,4 & 8,7 & 1,8 \\
1998 & 979.276 & 166.174 & 17,0 & 17,3 & 0,0 & $-0,3$ & $-1,5$ \\
1999 & 1.065 .000 & 166.746 & 15,7 & 15,5 & 0,3 & $-8,2$ & $-1,2$ \\
2000 & 1.179 .482 & 198.151 & 16,8 & 15,8 & 4,3 & 5,0 & 2,8 \\
2001 & 1.302 .136 & 221.772 & 17,0 & 16,7 & 1,3 & 0,4 & $-0,2$ \\
2002 & 1.477 .822 & 242.162 & 16,4 & 15,7 & 2,7 & $-5,2$ & 1,2 \\
2003 & 1.699 .948 & 259.714 & 15,3 & 15,5 & 1,1 & $-4,6$ & $-0,3$ \\
2004 & 1.941 .498 & 312.516 & 16,1 & 15,8 & 5,7 & 9,1 & 4,2 \\
2005 & 2.147 .944 & 349.463 & 16,3 & 16,2 & 2,9 & 3,6 & 1,5 \\
2006 & 2.322 .818 & 390.134 & 16,8 & $\ldots$ & 3,7 & 8,7 & 2,3 \\
\hline
\end{tabular}

Fonte: Contas Nacionais, IBGE (2007a).

(...) Não disponível.

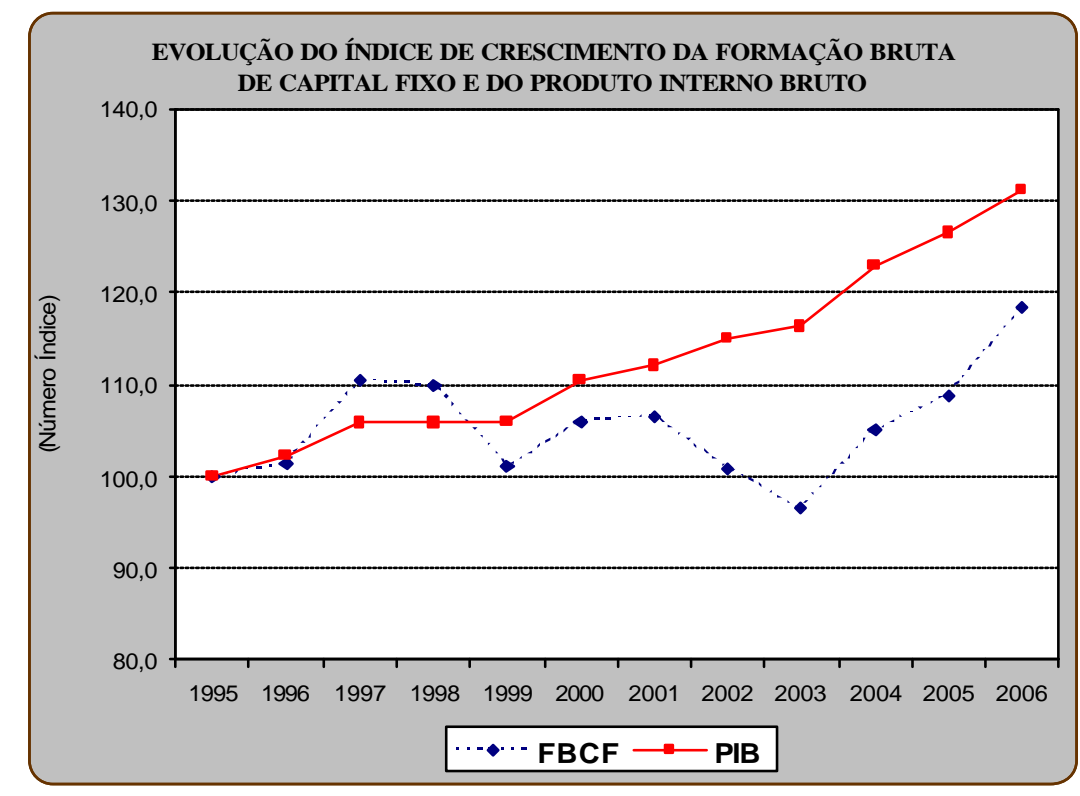

Fonte: IBGE (2007a) - Departamento de Contas Nacionais.

Figura 4 - Evolução do Índice de Crescimento do PIB e da FBKF

As variações na taxa de investimento de bens de capital têm refletido diretamente na capacidade de produção dos setores, e nas características do comércio exterior das máquinas do Brasil.

Em primeiro lugar, a produção nacional de máquinas e equipamentos tem 
perdido sua participação no mercado interno para outros países - em 2000, a produção nacional do setor representava cerca de 60\% do valor atingido em 1980 (ALEM; PESSOA, 2005). O suprimento do mercado interno passou a contar não só com maior participação de produtos estrangeiros (VERMULM, 2003), como o perfil dos componentes e peças comprados pelo Brasil apresentou maior conteúdo tecnológico.

Além disso, no comércio internacional as empresas brasileiras de máquinas têm consolidado a dinâmica exportadora para mercados que compram com base em preços, nos segmentos em que a competição é mais acirrada com os países asiáticos (VERMULM, 2003, p. 13).

Os segmentos de bens de capital mecânico, por exemplo, têm apresentado saldos negativos no comércio exterior nos últimos anos, e têm investido no aumento do nível de exportações como forma de compensar as flutuações da demanda interna por máquinas (tabela 3). Entretanto, a taxa de crescimento das importações tem sido relativamente maior que o aumento das taxas de exportação de máquinas.

Tabela 3 - Evolução do comércio brasileiro de bens de capital mecânicos

\begin{tabular}{lccccccccccc}
\hline Comércio exterior & 1996 & $\mathbf{1 9 9 7}$ & $\mathbf{1 9 9 8}$ & $\mathbf{1 9 9 9}$ & $\mathbf{2 0 0 0}$ & $\mathbf{2 0 0 1}$ & $\mathbf{2 0 0 2}$ & $\mathbf{2 0 0 3}$ & $\mathbf{2 0 0 4}$ & $\mathbf{2 0 0 5}$ & $\mathbf{2 0 0 6}$ \\
\hline $\begin{array}{l}\text { Exportação } \\
\text { (US\$ milhões) }\end{array}$ & 3.389 & 3.901 & 3.727 & 3.298 & 3.518 & 3.591 & 3.701 & 4.940 & 6.842 & 8.588 & 9.656 \\
$\begin{array}{l}\text { Crescimento da } \\
\text { exportação (\%) }\end{array}$ & - & 15,1 & $-4,5$ & $-11,5$ & 6,7 & 2,1 & 3,1 & 33,5 & 38,5 & 25,5 & 12,4 \\
$\begin{array}{l}\text { Importação } \\
\text { (US \$ milhões) }\end{array}$ & 6.594 & 8.820 & 8.349 & 7.129 & 6.501 & 7.244 & 6.189 & 5.795 & 6.837 & 8.490 & 9.844 \\
$\begin{array}{l}\text { Crescimento da } \\
\text { importação (\%) }\end{array}$ & - & 33,8 & $-5,3$ & $-14,6$ & $-8,8$ & 11,4 & $-14,6$ & $-6,4$ & 18,0 & 24,2 & 15,9 \\
$\begin{array}{l}\text { Saldos } \\
\text { (US\$ milhões) }\end{array}$ & -3.205 & -4.919 & -4.622 & -3.831 & -2.983 & -3.653 & -2.488 & -855 & 5 & 98 & -188 \\
\hline Fonte: ABIMAQ/SINDIMAQ e SECEX. Disponível em IBGE (2007a). & & & & & & & & & & &
\end{tabular}

As alterações na pauta de produção e de comércio do setor de máquinas nacional refletem não apenas as condições macroeconômicas, mas também a entrada de alguns países na produção mundial de bens de capital e a transferência de alguns ramos para os países em industrialização do leste asiático (Coréia do Sul, Hong Kong, Índia e a China). A China, por exemplo, é um dos principais países produtores e exportadores mundiais de máquinas e equipamentos.

$\mathrm{Na}$ década passada, as empresas chinesas produziam sem tecnologias de 
ponta e com um diferencial de preços muito grande relativamente aos produtos brasileiros, o que acarretou elevadas taxas de importação da China, em especial nos setores de máquinas e de bens de consumo. Já nos últimos anos, a produção chinesa foi deslocada para produtos com maior sofisticação tecnológica dos ramos de máquinas e equipamentos, componentes eletrônicos, entre outros ${ }^{22}$.

O desempenho produtivo e de comércio exterior da indústria de bens de capital tem respondido, em parte, às pressões do mercado internacional de máquinas. O setor tem apresentado uma recuperação gradual da fatia de produção destinada ao mercado externo, enquanto as exportações avançaram do percentual de $20 \%$ da produção em 2000, para 35\% em 2005, com destaque para os segmentos de máquinas agrícolas e para a construção civil (INDÚSTRIA..., 13/jul/06). Mas é importante destacar que esse comportamento das vendas para o mercado externo não é comum em toda a indústria de máquinas, em virtude das capacitações distintas para competir com produtores de outros países ${ }^{23}$.

A participação das máquinas e equipamentos importados no consumo brasileiro também aumentou de 32\% em 2004 para 36\% em 2006, com destaque para o segmento de máquinas industriais - principalmente as injetoras plásticas (INDÚSTRIA...,13/jul/06) em que as empresas chinesas competem com os fabricantes nacionais.

As transformações em curso na economia brasileira e as medidas macroeconômicas adotadas nas últimas décadas repercutiram na estrutura de produção e comércio das máquinas e equipamentos nacionais. Entretanto, a concorrência com alguns ramos de máquinas dos países asiáticos tem dificultado o desempenho e a especialização das empresas brasileiras de máquinas em vários níveis de conteúdo tecnológico.

As empresas nacionais têm adquirido componentes dos fabricantes chineses como forma de reduzir seus custos e assim ganhar competitividade para enfrentar a concorrência internacional - inclusive com a própria China (A CHINA.., 25/mai/07).

\footnotetext{
${ }^{22}$ Para se ter uma idéia da mudança na participação chinesa no mercado brasileiro, no ano de 1997 os cinco principais produtos comprados eram bens de consumo; em 2006 esses principais produtos eram bens de consumo de maior valor agregado (computador) ou eram componentes - partes e peças para telecomunicações, partes e peças para informática, circuitos integrados e dispositivos de cristais líquidos (A CHINA..., 25/mai/07).

${ }^{23}$ No último ano, o segmento de máquinas-ferramenta, por exemplo, aumentou em $10,3 \%$ (em valores) as exportações, enquanto as vendas para o mercado interno registraram um pequeno recuo (MERCADO..., 09/fev/2007). Por outro lado, os segmentos de máquinas para injetados plásticos têm
} 
Outra estratégia utilizada por empresas brasileiras de bens de capital é a transferência de unidades produtivas para a China, principalmente nos segmentos de veículos automotores e de máquinas e materiais elétricos, entre outros (CONCORRÊNCIA..., 12/mar/2007).

Os preços praticados pelos fabricantes de máquinas da China são os mais competitivos $^{24}$, mas é importante considerar que a concorrência da pauta produtiva da China não decorre só da escala - que confere reduzidos preços de mercado. Nos últimos dezessete anos, a política industrial chinesa tem realizado incentivos à indústria de bens de capital e adotou planos de governo para impulsionar doze setores, entre eles o de máquinas (ABIMAQ..., Jun/06).

Como resultado dessas medidas, o setor de máquinas da China tem crescido, em média, 15\% ao ano, e em 2002-2003 cresceu 32\%. As exportações de máquinas chinesas para o Brasil, por exemplo, apresentaram um crescimento de $85,46 \%$ em 2005 que é maior que a taxa de crescimento das vendas realizadas para o mundo $(48,79 \%)$ no mesmo período, como pode ser observado na tabela 4 (ABIMAQ...,Jun/06).

Tabela 4 - Exportações de máquinas e equipamentos da China.

\begin{tabular}{ccccc}
\hline Ano & $\begin{array}{c}\text { Exportações } \\
\text { para o mundo } \\
(\mathbf{1})\end{array}$ & $\begin{array}{c}\text { Taxa de } \\
\text { crescimento } \\
(\mathbf{\%})\end{array}$ & $\begin{array}{c}\text { Exportações } \\
\text { para o Brasil } \\
\mathbf{( 2 )}\end{array}$ & $\begin{array}{c}\text { Taxa de } \\
\text { crescimento } \\
\mathbf{( \% )}\end{array}$ \\
\hline 2002 & 13,6 & - & 62,7 & - \\
2003 & 18,2 & 33,94 & 81,8 & 30,44 \\
2004 & 24,7 & 35,83 & 145,8 & 78,27 \\
2005 & 36,8 & 48,79 & 270,4 & 85,46 \\
\hline
\end{tabular}

Fonte: DEE-ABIMAQ (dados com base no Secex e Tradstat) e Patrícia Marrone.

(1) US\$ bilhões FOB; (2) US\$ milhões FOB.

Já as importações de máquinas brasileiras realizadas pelas empresas chinesas, por sua vez, apresentaram crescimento de 38, $9 \%$, como pode ser observado na tabela 5 a seguir.

apresentado queda das vendas destinadas à América Latina.

24 Em 2006, os produtos chineses custavam até $50 \%$ do valor das máquinas brasileiras (INVASÃO...,18/jan/06) 
Tabela 5 - Importações de máquinas e equipamentos da China.

\begin{tabular}{ccccc}
\hline Ano & $\begin{array}{c}\text { Importações } \\
\text { do mundo (1) }\end{array}$ & $\begin{array}{c}\text { Taxa de } \\
\text { crescimento } \\
(\%)\end{array}$ & $\begin{array}{c}\text { Importações } \\
\text { do Brasil (2) }\end{array}$ & $\begin{array}{c}\text { Taxa de } \\
\text { crescimento } \\
(\%)\end{array}$ \\
\hline 2002 & 30,9 & - & 68,7 & - \\
2003 & 41,2 & 33,3 & 96,1 & 39,76 \\
2004 & 53,3 & 29,47 & 162,1 & 68,73 \\
2005 & 53,7 & 0,78 & 225,2 & 38,92 \\
\hline
\end{tabular}

Fonte: DEE-ABIMAQ (dados com base no Secex e Tradstat) e Patrícia Marrone.

(1) US $\$$ bilhões FOB; (2) US $\$$ milhões FOB.

Os principais segmentos em que as empresas brasileiras têm enfrentado a concorrência chinesa são as injetoras de plástico, têxtil, refrigeração, transmissão e máquinas-ferramentas, como pode ser verificado a partir dos dados de exportação por segmentos apresentados na tabela 6 . Já os segmentos de energia, agrícola e aqueles relacionados à infra-estrutura e saneamento têm apresentado maiores condições de enfrentar a competição com empresas da China (ABIMAQ..., Jun/06).

Tabela 6 - Principais segmentos exportadores de máquinas da China.

\begin{tabular}{lcc}
\hline \multicolumn{1}{c}{ Segmentos } & $\begin{array}{c}\text { Exportações para o } \\
\text { mundo - 2005 (1) }\end{array}$ & $\begin{array}{c}\text { Exportações para o } \\
\text { Brasil - 2005 (2) }\end{array}$ \\
\hline Máquinas-ferramenta & 7.323 .740 .980 & 55.504 .714 \\
Bombas & 2.690 .719 .298 & 38.735 .544 \\
Transmissão mecânica & 1.787 .269 .310 & 24.994 .482 \\
Ferramentaria e Modelação & 1.926 .927 .731 & 13.924 .901 \\
Máquina para plástico & 2.457 .623 .363 & 469.423 \\
Embalagens & 353.664 .438 & 571.614 \\
Refrigeração industrial & 912.306 .891 & 321.786 \\
\hline
\end{tabular}

Fonte: DEEE-Abimaq (dados com base no tradstat).

(1) US $\$$ bilhões FOB; (2) US $\$$ milhões FOB.

A indústria brasileira de máquinas e equipamentos está tentando atenuar os efeitos da concorrência com outros países, por meio de investimentos voltados à sua dinâmica competitiva e tecnológica e reforçando alguns atributos conquistados pelas empresas nacionais nos últimos anos.

De acordo com dados levantados pela Associação Brasileiras das Indústrias de Máquinas e Equipamentos (ABIMAQ) junto a empresas de todos os portes, os investimentos totais realizados pelo setor de máquinas em 2006 foram de $R \$ 6,89$ bilhões - o maior valor já registrado pelo setor desde $1995^{25}$ (SETOR DE

\footnotetext{
${ }^{25}$ A informação apresentada pela entidade representa um crescimento de $11,4 \%$ sobre os valores investidos em 2005 (que somaram $\mathrm{R} \$ 6,18$ bilhões), sendo que $33,5 \%$ foram utilizados em modernização tecnológica; $29,8 \%$, na ampliação da capacidade produtiva; $25,5 \%$, na reposição de
} 
MÁQUINAS INVESTE..., 27/fev/2007).

No âmbito das políticas públicas, a Política Industrial, Tecnológica e de Comércio Exterior (PITCE) definida pelo Ministério do Desenvolvimento, Indústria e Comércio Exterior (MDIC) em 2004 estabeleceu um conjunto de metas voltadas à indústria de bens de capital, entre outros setores, com o objetivo de aumentar a eficiência da estrutura produtiva; melhorar a capacidade de inovação e de difusão de tecnologias; e ampliar as exportações (ALEM; PESSOA, 2005, p. 74).

É importante considerar que o setor de máquinas tem apresentado vários exemplos de estratégias individuais de empresas que estão revisando as decisões produtivas e de desenvolvimento tecnológico na tentativa de enfrentar a concorrência com os fabricantes estrangeiros. Empresas do ramo de máquinasferramenta, como a Romi, a Ergomat e a Maquenge, por exemplo, estão buscando parcerias com empresas da Alemanha, França, Espanha, Estados Unidos e China (MERCADO..., 09/02/2007); enquanto no ramo agrícola, a americana Massey Ferguson, pode ser destaca como exemplo dos investimentos deste setor em tecnologia de ponta (SETOR DE MÁQUINAS MOVIMENTA..., 09/out/06).

Nos segmentos de máquinas voltadas para setores tradicionais, 0 desenvolvimento das empresas brasileiras de máquinas pode ser atribuído, principalmente, ao atendimento da demanda e das necessidades do mercado interno. As empresas de máquinas para calçados, por exemplo, contam com atributos como qualidade e adequação da tecnologia aos processos requeridos pelos usuários, facilidade de comunicação (principalmente na América Latina) e assistência técnica bem mais facilitada (CHINESES..., 07/abr/06) que interferem sobremaneira na sua competitividade no mercado interno e foram construídos e armazenados à dinâmica interna das empresas ao longo do tempo, por meio de interações sociais e dos contatos estabelecidos com empresas dos segmentos a jusante e a montante.

De maneira geral, o desenvolvimento e a realização de melhorias nos atributos competitivos das empresas nacionais podem ser influenciados pela

máquinas antigas, e $11,2 \%$, na aquisição de equipamentos de informática e imóveis, entre outros (SETOR DE MÁQUINAS INVESTE..., 27/fev/2007). Outro fator relevante é o aumento dos investimentos realizados por empresas de pequeno porte: as microempresas participaram com $R \$$ 281,75 milhões, as pequenas com $R \$ 1.193$ milhões, as médias com $R \$ 1.111$ milhões e as grandes com $R \$ 4.306$ milhões (SETOR DE MÁQUINAS INVESTE..., 27/fev/07). 
heterogeneidade na dimensão produtiva e pela estrutura de oferta do setor discutida neste capítulo. Além disso, o deslocamento da produção mundial de máquinas para os países asiáticos tem refletido de maneira distinta no desempenho e desenvolvimento tecnológico dos segmentos de máquinas.

O próximo tópico discute brevemente a diversidade de competências e ativos e os mecanismos de aprendizado envolvidos na produção de bens de capital que devem ser considerados no desenvolvimento e adensamento das relações entre as empresas de máquinas e seus usuários.

\subsection{O desenvolvimento de capacidades e tecnologias em bens de capital}

Nos últimos anos, a indústria brasileira de bens de capital consolidou o perfil de produção de máquinas e equipamentos com baixo grau de sofisticação tecnológico (VERMULM, 2003, p. 13) e intensivo em mão-de-obra, o que pode comprometer o desenvolvimento de competências tecnológicas do país no longo prazo.

As principais justificativas para esse desempenho do setor nos últimos anos é que, de um lado, os investimentos em pesquisa e desenvolvimento de tecnologias são relativamente menores do que os gastos realizados em outros países; de outro, as condições macroeconômicas e a heterogeneidade dos segmentos e empresas de bens de capital impõem uma diversidade de situações, que dificultam o desenvolvimento de capacidades e tecnologias nas empresas de máquinas.

Os instrumentos utilizados por empresas brasileiras para acessar as novas tecnologias também podem ajudar a caracterizar a dinâmica de desenvolvimento de competências em bens de capital.

No Brasil, os mecanismos mais usados em segmentos de bens de capital para acessar as informações tecnológicas desenvolvidas no exterior são o licenciamento de tecnologia estrangeira e a importação de máquinas e equipamentos. Já no exterior, o instrumento mais utilizado para adquirir as melhorias técnicas e intangíveis é o licenciamento cruzado entre firmas que trocam conhecimentos específicos e o direito de uso de marcas (ERBER; VERMULM, 2002, p. 14). 
Nas décadas passadas, o licenciamento de tecnologias possibilitou a entrada de muitas empresas multinacionais em mercados protegidos, como o Brasil. Em geral, as empresas estrangeiras negociavam as suas entradas nesses mercados em troca da permissão para a comercialização de suas máquinas com tecnologias simples no mercado do país protegido.

Entretanto, o estabelecimento de uma área de livre comércio nos últimos anos resultou no desaparecimento de ativos locais específicos e mudou essa dinâmica de licenciamento de tecnologias (ERBER; VERMULM, 2002, p. 14). Nesse cenário, a aquisição de tecnologias a partir da importação de máquinas tornourse a principal fonte de atualização tecnológica das firmas nacionais, especialmente aquelas de maior porte (ERBER; VERMULM, 2002).

É importante observar que 0 acesso às tecnologias de ponta e, principalmente, o desenvolvimento de inovações em produtos e processos a partir desses dois mecanismos - licenciamento e importação de máquinas e equipamentos - dependem muito das condições apresentadas por firmas nacionais para acumular conhecimentos e trocar ativos pela tecnologia oferecida pela firma estrangeira. Segundo dados da última Pesquisa de Inovação Tecnológica (PINTEC) realizada junto à empresas nacionais de todos os segmentos, a aquisição de bens e capital é a principal forma de investimentos realizados visando a modernização tecnológica ${ }^{26}$.

Adicionalmente, o modo como a empresa tem incorporado as informações técnicas à sua trajetória também difere consideravelmente entre os grupos de bens de capital. Os segmentos que trabalham com produtos mais maduros e têm sua engenharia de produto menos vinculado ao sistema cientifico e tecnológico, por exemplo, utilizarão mais intensamente a engenharia reversa e a reengenharia como fontes de aprendizado. Já os segmentos que detêm capacidades para a produção de bens com mais sofisticação tecnológica, contam com os conhecimentos técnicos e de produtos adquiridos em outros países, com os acordos voltados à pesquisa e desenvolvimento e com as interações estabelecidas com empresas e institutos de pesquisa do mercado interno (ERBER; VERMULM, 2002). Nesse sentido, os encadeamentos intra-empresa estabelecidos a partir das

\footnotetext{
${ }^{26}$ Cerca de $52,2 \%$ dos investimentos realizados por empresas nacionais na inovação de produtos e de processos referem-se à aquisição de máquinas e equipamentos (IBGE, 2007b; AVELLAR, 2004).
} 
interações entre usuários e fornecedores são relevantes para o aprendizado tecnológico de produtos mais maduros e podem ajudar na formação de competências nas empresas brasileiras de máquinas.

\section{A heterogeneidade entre empresas fornecedoras e usuárias de} máquinas também impõe um conjunto de fatores que podem acentuar ou modificar as competências criadas ao longo do tempo.

Nos períodos de prosperidade econômica, em que os usuários recorrem à expansão da sua capacidade produtiva, mesmo que o mercado externo apresente uma extensa oferta de máquinas novas e recondicionadas, as empresas de médio e pequeno porte recorrem, principalmente, às inovações incrementais embutidas nos equipamentos do mercado interno. $\mathrm{E}$ os produtores de máquinas atentos a essas demandas, por sua vez, podem diversificar as opções numa mesma linha de produtos, com o objetivo de atender aos requisitos de custo e qualidade requeridos por clientes de faixas distintas de consumo.

Já nos períodos de recessão, em que há baixa demanda por reposição e ampliação da capacidade, o setor de máquinas nacional pode ser responsável por alterações muito específicas nas funções dos equipamentos existentes, visando a resolução de problemas técnicos nas empresas usuárias. A pequena demanda por máquinas pode resultar na contenção dos investimentos, mas aproxima fornecedores e usuários, contribuindo para a ampliação das competências em ambos os grupos de empresas.

Alguns estudos sobre as trajetórias de acumulação de tecnologias realizadas por empresas de vários setores industriais (TACLA, 2002; BUTTENBENDER, 2005, entre outros) têm destacado que as diferenças nas taxas de acumulação de competências (medida em anos) e as distintas estratégias de aprendizado intrafirmas interferem mais nas atividades inovativas de uma empresa do que os fatores do ambiente externo em que ela está inserida.

O tempo gasto pelas empresas para converter informações provenientes de fontes externas em competências de rotinas - os estágios de incorporação de informações para o desenvolvimento de produtos - são fundamentais para o seu desenvolvimento tecnológico.

A empresa multinacional de máquinas para papel-celulose Kvaerner Pulping, 
por exemplo, tem seu desempenho competitivo determinado pela aceleração da taxa de acumulação de competências internas e pela forma como o aprendizado interno e externo à empresa é realizado em atividades de rotina e inovadoras (TACLA, 2002).

Tacla e Figueiredo (2002) consideram que a dimensão organizacional da empresa está voltada à aquisição de informações (interna e externa) e à conversão destas informações em conhecimentos por meio da socialização e codificação, que possibilitam a realização de melhoramentos incrementais e a sustentação de competências tecnológicas ao longo do tempo (TACLA; FIGUEIREDO, 2002). Nesse sentido, o modo e a forma como a empresa acumulou suas competências pode representar um atributo competitivo específico e diferenciado do que ocorre em outras empresas de máquinas para papel e celulose.

Os SLPs de calçados de Novo Hamburgo (RS) e de Franca (SP), por sua vez, ilustram os mecanismos para a aquisição de informações a partir de interações intrafirmas e como ocorre a acumulação de competências ao longo das cadeias produtivas. Como o grau de amadurecimento tecnológico das máquinas para calçados é relativamente distinto do patamar apresentado por empresas de máquina de outros setores, é importante considerar a estrutura produtiva e industrial das empresas de calçados e de máquinas e como essas características refletem em seus inter-relacionamentos com outros ramos industriais, como será apresentado no próximo capítulo. 


\section{A indústria de máquinas para couro e calçados no Brasil}

\subsection{A indústria de calçados: desenvolvimento industrial e tecnológico}

A indústria nacional de calçados é formada por 9.032 estabelecimentos, responsáveis pelo emprego formal de 298.659 pessoas, e que produzem cerca de 725 milhões de pares, segundo dados da Resenha Estatística Abicalçados para o ano de 2005 (ABICALÇADOS, 2007a).

Em termos geográficos, os cinco principais Estados brasileiros com produção de calçados - Rio Grande do Sul, São Paulo, Ceará, Minas Gerais e Bahia representavam $91,1 \%$ do emprego do setor e $88,6 \%$ do total de empresas nacionais de calçados em 2005, como pode ser verificado na tabelas 7 e 8 a seguir.

Tabela 7 - Número de funcionários nos principais Estados com produção de calçados do Brasil.

\begin{tabular}{lcccc}
\hline Estados & $\begin{array}{c}\text { Total de } \\
\text { emprego em } \\
\mathbf{2 0 0 5}\end{array}$ & $\begin{array}{c}\text { Participação no } \\
\text { total do setor em } \\
\mathbf{2 0 0 5}(\mathbf{\%})\end{array}$ & $\begin{array}{c}\text { Total de } \\
\text { emprego em } \\
\mathbf{2 0 0 4}\end{array}$ & $\begin{array}{c}\text { Participação no } \\
\text { total do setor em } \\
\mathbf{2 0 0 4}(\%)\end{array}$ \\
\hline Rio Grande do Sul & 126.784 & 42,45 & 143.022 & 45,76 \\
São Paulo & 54.570 & 18,27 & 56.993 & 18,23 \\
Ceará & 44.268 & 14,82 & 45.982 & 14,71 \\
Minas Gerais & 23.515 & 7,87 & 23.137 & 7,40 \\
Bahia & 22.973 & 7,69 & 19.781 & 6,33 \\
Subtotal & 272.110 & 91,11 & 288.915 & 92,43 \\
Outros Estados (1) & 26.549 & 8,89 & 23.664 & 7,57 \\
TOTAL & 298.659 & 100,00 & 312.579 & 100,00 \\
\hline Fonte: Ministério do Trabalho e Emprego/RAIS. Disponível em: Abicalçados (2007), Resenha Estatística. \\
Obs: Dados estimados pela Abicalçados com base em várias fontes. \\
(1) Outros Estados: Paraíba, Santa Catarina, Rio Grande do Norte, Paraná, Espírito Santo, Sergipe, Goiás, \\
Rio de Janeiro, Pernambuco, Mato Grosso do Sul, Alagoas, Pará, Mato Grosso, Distrito Federal, Maranhão, \\
Tocantins, Piauí.
\end{tabular}


Tabela 8 - Número de empresas nos principais Estados com produção de calçados do Brasil.

\begin{tabular}{lcccc}
\hline Estados & $\begin{array}{c}\text { Total de } \\
\text { empresas em } \\
\text { 2005 }\end{array}$ & $\begin{array}{c}\text { Participação no } \\
\text { total do setor (\%) }\end{array}$ & $\begin{array}{c}\text { Total de } \\
\text { empresas de } \\
\mathbf{2 0 0 4}\end{array}$ & $\begin{array}{c}\text { Participação no } \\
\text { total do setor (\%) }\end{array}$ \\
\hline Rio Grande do Sul & 3.419 & 37,85 & 3.192 & 37,85 \\
São Paulo & 2.776 & 30,74 & 2.542 & 30,14 \\
Ceará & 221 & 2,45 & 205 & 2,43 \\
Minas Gerais & 1.493 & 16,53 & 1.410 & 16,72 \\
Bahia & 95 & 1,05 & 104 & 1,23 \\
Subtotal & 8.004 & 88,62 & 7.453 & 88,38 \\
Outros Estados (1) & 1.028 & 11,38 & 980 & 88,38 \\
TOTAL & 9.032 & 100,00 & 8.433 & 11,62 \\
\hline
\end{tabular}

Fonte: Ministério do Trabalho e Emprego/RAIS. Disponível em: Abicalçados (2007), Resenha Estatística.

Obs: Dados estimados pela Abicalçados com base em várias fontes.

(1) Outros Estados: Paraíba, Santa Catarina, Rio Grande do Norte, Paraná, Espírito Santo, Sergipe, Goiás,

Rio de Janeiro, Pernambuco, Mato Grosso do Sul, Alagoas, Pará, Mato Grosso, Distrito Federal, Maranhão,

Tocantins, Piauí.

O desempenho da indústria de calçados pode ser explicado por dois conjuntos de fatores: de um lado, as variações da renda interferem no poder aquisitivo dos consumidores, principalmente na faixa de produtos de consumo de massa, refletindo na demanda do setor. De outro lado, a competitividade das empresas está baseada em fatores como o custo da mão-de-obra ou o acesso privilegiado a matérias-primas - vantagens competitivas de caráter estático (GARCIA et al, 2004) - repercutindo nas condições de oferta do setor de calçados nacional.

A organização do setor de calçados em sistemas locais de produção (SLPs) é uma característica importante para o seu desenvolvimento industrial e a capacidade de gerar melhorias para todos os segmentos de calçados.

No Brasil, a aglomeração espacial de empresas e instituições com atividades voltadas à produção de calçados determina a geração de economias externas de caráter incidental e deliberado, permite a exploração de sinergias produtivas e confere ao setor de calçados a capacidade de atualização tecnológica (AZEVEDO, 2002), refletindo na ealização de vantagens concorrenciais que seriam de difícil alcance se as empresas atuassem isoladamente no mercado. Nesse cenário, a cadeia calçadista apresenta forte integração entre os segmentos de produção de calçados e outros ramos industriais como a indústria química, têxtil e vestuário e móveis, como representado na figura 5 a seguir. 


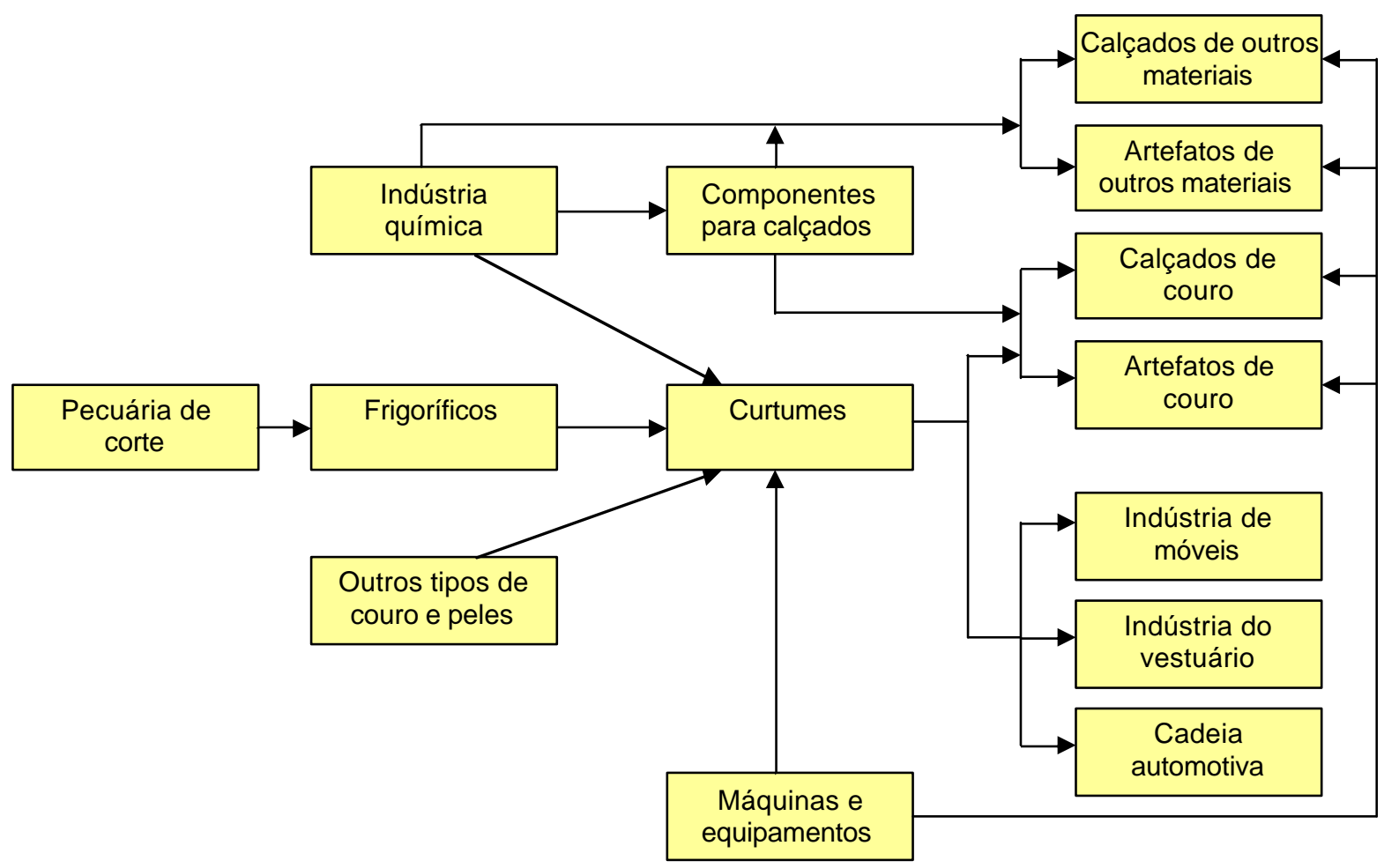

Fonte: Garcia (2005).

Figura 5 - Segmentos da cadeia de calçados e sua integração com outros ramos industriais

Os principais SLPs de calçados do Brasil estão localizados no Vale do Sinos ${ }^{27}$ (RS) - a maior produtora nacional de calçados femininos; e na cidade de Franca $(\mathrm{SP})$, que é especializada na produção de calcados masculinos.

O Vale do Rio dos Sinos, no Rio Grande do Sul, é o principal pólo de produção de calçados (voltado para o segmento feminino), responsável por aproximadamente $40 \%$ da produção nacional e $70 \%$ das exportações totais (em volume). O SLP desta região conta com a participação de $80 \%$ dos produtores nacionais de máquinas para calçados e cerca de $60 \%$ dos fornecedores de componentes, além de instituições com atuação na capacitação da mão-de-obra (SENAI, UNISINOS) e instituições de apoio como IBTEC, ABICALÇADOS, ABRAMEQ, ASSINTECAL, entre outras (ABICALÇADOS, 2007b; ANDRADE; CORREA, 2001).

O SLP de calçados da cidade de Franca, no Estado de São Paulo, é o segundo maior produtor de calçados do país (com especialização em sapatos

\footnotetext{
${ }^{27}$ Vale do Sinos é a denominação para Vale do Rio dos Sinos que abrange os municípios de Nova Hartz, Araricá, Sapiranga, Campo Bom, Nova Sta Rita, Sapucaia, Esteio, Novo Hamburgo, Dois Irmãos, Ivoti, Estância Velha, Portão, Canoas e São Leopoldo (ABICALÇADOS, 2007b).
} 
masculinos), sendo responsável por $6 \%$ da produção nacional e $3 \%$ das exportações totais. Assim como o SLP do Vale do Sinos, o pólo calçadista de Franca apresenta uma estrutura produtiva completa, com a presença de empresas e instituições de todas as etapas da produção de calçados, que compreende desde produtores de insumos até solados, adesivos, matrizarias, máquinas e equipamentos, e instituições de apoio e ensino como IPT, SENAI, SEBRAE e Universidades (ABICALÇADOS, 2007b; ANDRADE; CORREA, 2001).

Outros SLPs de calçados localizam-se nas cidades de Birigui/SP (calçados infantis), Jaú/SP (calçados femininos) e na cidade de Nova Serrana/MG, que tem apresentado importante dinamismo na produção de calçados esportivos.

A partir dos anos 90, alguns Estados da região Nordeste também passaram a produzir calçados, em especial no segmento de calçados esportivos e sandálias à base de EVA, o que repercutiu na relocalização de unidades produtivas dos principais pólos produtores tradicionais. A relocalização da produção de calçados, principalmente para os Estados do Ceará, Bahia e Paraíba, foi incentivada por três fatores: custo de produção relativamente reduzido - seja na aquisição de insumos ou na utilização de mão-de-obra; isenção fiscal e tributária oferecida para a instalação de unidades em outras regiões; e melhores condições para a realização de investimentos às empresas que desejassem instalar suas unidades de fabricação na região Nordeste. Nesse contexto, as regiões Sul e Sudeste perderam a participação no total da produção e do emprego do setor de calçados GARCIA, 2005), mas como as empresas que transferiram unidades para o Nordeste fabricam linhas de produtos complementares às linhas existentes nas regiões tradicionais calçados de menor valor agregado - a relocalização não alterou o perfil tecnológico do setor.

Os segmentos de calçados apresentam uma diversidade de estruturas competitivas com participação em todas as etapas da cadeia, o que abrange desde a atividade de processamento de couro até a produção de calçados. Além disso, as empresas de todos os segmentos da indústria calçadista apresentam uma forte heterogeneidade produtiva que pode ser explicada por duas características do seu padrão de concorrência: a segmentação da produção e a segmentação do mercado (GARCIA, 2005).

A produção de calçados é realizada em duas fases, a preparação do material e a montagem do calçados. A fase de preparação da matéria-prima é realizada nos 
curtumes, que se encarregam da extração, processamento e acabamento do couro. A fase de fabricação do calçados, por sua vez, pode ser realizada ras seguintes etapas: design, modelagem, corte, costura, montagem e acabamento apresentadas no quadro $5^{28}$.

\begin{tabular}{|c|c|}
\hline $\begin{array}{l}\text { Etapas de } \\
\text { produção de } \\
\text { calcados }\end{array}$ & $\begin{array}{l}\text { Descrição } \\
\text { das atividades }\end{array}$ \\
\hline & $\begin{array}{l}\text { Definição do projeto (conceito) do produto, com as características desde o } \\
\text { desenho até os insumos necessários à sua realização. }\end{array}$ \\
\hline Design & $\begin{array}{l}\text { É a fase em que ocorre maior agregação de valor. Nas empresas de pequeno e } \\
\text { médio porte, esta etapa é realizada por meio de pesquisa das principais } \\
\text { tendências de mercado pelo modelista, que faz as adaptações para os seus } \\
\text { mercados. }\end{array}$ \\
\hline Modelagem & $\begin{array}{l}\text { Desenho, planificação e otimização do corte dos moldes do sapato. Nesta etapa } \\
\text { são definidos todos os materiais da fabricação (como as navalhas de corte), o } \\
\text { tipo, o gênero, a finalidade e o projeto da fôrma. }\end{array}$ \\
\hline \multirow[t]{2}{*}{ Corte } & $\begin{array}{l}\text { Corte das peças - de couro ou outro material - de acordo com as dimensões } \\
\text { definidas na modelagem; Recorte; Dublagem; Divisão e Cambrê. } \\
\text { O processo de corte pode ser manual (com a utilização de facas) ou mecânico } \\
\text { (com o uso de navalhas). O corte manual é mais adequado para pequenas } \\
\text { quantidades de peças ou na etapa de desenvolvimento do produto, quando são } \\
\text { confeccionados os modelos que servirão de base para a linha de produção. O } \\
\text { corte mecânico, por sua vez, é utilizado para grandes lotes de peças, visto que } \\
\text { proporcionam maior produtividade e a qualidade das peças cortadas. }\end{array}$ \\
\hline & $\begin{array}{l}\text { Os processos de corte a laser e a jato d'água apresentam ganhos de produção e } \\
\text { melhor aproveitamento do material porque o computador envia os comandos } \\
\text { para as máquinas, que efetuam os desenhos sobre o couro ou o aminado } \\
\text { sintético. }\end{array}$ \\
\hline Costura & $\begin{array}{l}\text { Compreende as atividades de costura (reunião das peças formando o cabedal); a } \\
\text { chanfração (rebaixamento das bordas das peças para diminuir o volume da peça } \\
\text { e não machucar os pés nas emendas das peças); o virado (virar as bordas da } \\
\text { peça antes da costura para melhorar o visual) e a colocação de forros e } \\
\text { espumas. O trabalho de preparação, na maior parte das empresas, é realizado } \\
\text { manualmente e, em algumas poucas, feito em máquinas eletrônicas simples. }\end{array}$ \\
\hline Montagem & $\begin{array}{l}\text { Nesta etapa - realizada quase simultaneamente ao corte e costura - os } \\
\text { materiais que compóem o solado (salto e sola) e as palmilhas são cortadas, } \\
\text { lixadas, conformadas, limpas, coladas ou costuradas ao cabedal (ANDRADE e } \\
\text { CORREA, 2001, p. 104). Também se monta a biqueira, o enfraque e a } \\
\text { calcanheira e prega-se o salto. }\end{array}$ \\
\hline Acabamento & $\begin{array}{l}\text { Nesta etapa (plancheamento) são realizadas as operações de acabamento: } \\
\text { frisar, lixar, pintar, secar, limpar, retocar pequenos defeitos e o controle da } \\
\text { qualidade final do calçado. }\end{array}$ \\
\hline
\end{tabular}

Fonte: Alves Filho (1991); Gazeta Mercantil (2000); Andrade e Correa (2001); CTCCA (2002); Ruffoni (2004); Diehl (2005).

\section{Quadro 5 - Etapas da produção de calçados.}

\footnotetext{
${ }^{28}$ As características da tecnologia e das máquinas utilizadas em cada etapa de produção de calçados serão analisadas no próximo capítulo.
} 
Outra característica importante da indústria calçadista brasileira é a segmentação da produção em vários tipos e modelos de calçados, que são responsáveis por capacitações distintas entre as empresas e pela realização de atributos específicos à cadeia calçadista nacional.

A especialização da produção em vários tipos de calçados - esportivos, casuais, sapatos de segurança e sociais - estimulam a atuação de empresas especializadas em algumas áreas, enquanto outras assumem papel de fornecedoras de peças, componentes e serviços específicos para os produtores (GARCIA, 2005). Contudo, as variações da moda, as mudanças de estilo e design e a preferência por marcas e modelos com apelo ao conforto também contribui para a atuação de empresas com diferentes capacitações e níveis de eficiência sobrevivam no mercado (COSTA, 2002).

As inúmeras possibilidades para a produção de calçados refletem diretamente em sua segmentação de mercado. A intensidade em mão-de-obra e a relativa difusão das habilidades para produzir calçado possibilitam a produção com baixa necessidade de capital, o que justifica a existência de reduzidas barreiras à entrada de empresas em todas as etapas produtivas e a organização de empresas de diversos portes (CROCCO et al, 2001, p. 20).

Atualmente as empresas de calçados podem ser classificadas segundo 0 porte e os atributos competitivos (GORINI; SIQUEIRA, 1999a, p. 3):

- Empresas de grande porte - tiveram condições para investir em atributos produtivos e de comércio. Atuam basicamente no mercado interno, com forte presença na produção de tênis e calçados esportivos, cujos requisitos de tecnologia são mais sofisticados e as despesas de marketing mais altas.

- Médias empresas - estão ligadas ao segmento de couro que é bastante concorrido e pulverizado. Têm atuado principalmente no mercado externo, com níveis tecnológicos e gastos com marketing diferenciados.

- Micro e pequenas empresas - utilizam processos produtivos mais artesanais.

Além disso, a presença de etapas tecnologicamente separáveis (MDIC, 2001, p. 2) determina a organização de empresas com diferentes níveis de requerimentos tecnológicos atribuídos ao processo de fabricação de calçados e facilita a capacidade de trabalhar, simultaneamente, com uma ampla linha de produtos. $E$ por conta desses fatores, o setor apresenta elevada flexibilidade produtiva e capacidade 
de resposta rápida às elevações da demanda do mercado interno e externo (COSTA, 2002, p. 26).

A inserção da indústria brasileira de calçados no mercado mundial a partir da década de 70 possibilitou a expansão da produção e o desenvolvimento técnicoprodutivo das empresas nacionais, refletindo na dinâmica competitiva dos segmentos e na produtividade e qualidade dos calçados (GARCIA, 2005, p. 17).

Em grande parte, esse dinamismo técnico-produtivo foi resultado das interações entre os produtores brasileiros e os grandes compradores das cadeias internacionais do setor $^{29}$. A intermediação entre os fabricantes de calçados e os compradores mundiais era realizada por meio de escritórios de comercialização, responsáveis por garantir que requisitos como qualidade e prazos fossem atendidos pelos produtores nacionais (GARC IA, 2005, p. 22).

Cabe ressaltar que os compradores globais impedem o compartilhamento e geração de competências inovativas, restringem as estratégias de desenvolvimento de ativos intangíveis como design de produtos, criação de marcas e de canais de comercialização. E como resultado mais imediato, as empresas nacionais se especializaram em competências produtivas.

De maneira geral, as empresas de calçados de pequeno e médio porte têm mais dificuldades para realizar as atividades de desenvolvimento de produtos internamente porque essas funções são definidas pelos compradores. Entre as empresas de grande, por outro lado, a internalização do desenvolvimento de produtos é mais comum, porém, muitas empresas apresentam funcionários que adaptam as linhas encomendadas no mercado internacional ao seu processo produtivo (GARCIA, 2005, p. 22).

A questão que se coloca, neste ponto, é que se o modo utilizado pelas empresas de calçados para entrar no mercado internacional não repercutiu na criação de competências inovativas, por outro lado, foi fundamental para o seu desenvolvimento tecnológico a partir da mecanização da indústria de calçados e a incorporação de mudanças organizacionais discutidos na próxima seção.

\footnotetext{
${ }^{29}$ A organização da cadeia de calçados no mercado internacional e no Brasil a partir da interação com compradores internacionais - que comandam a produção e distribuição de produtos - é apresentada por Gereffi (1994) como cadeia dirigida pelo comprador.
} 


\subsubsection{O desenvolvimento de competências e tecnologias no setor de calçados}

A automação do setor de calçados pode ser caracterizada como processo bastante heterogêneo e que ocorre a partir de pequenos avanços incrementais, em virtude das especificidades nas condições competitivas das empresas e do nível de divisibilidade das etapas de produção (GAZETA MERCANTIL, 2000a).

O desenvolvimento tecnológico do setor data de meados da década de 40 , com o surgimento de novos materiais, o processo de mecanização e o crescimento da demanda. Entretanto, a fabricação de calçados não mudou muito o perfil tecnológico relativamente a outros ramos industriais como o setor têxtil (REICHERT, 2004, p. 52).

No período entre os anos 60 e 70, a indústria de calçados passou por transformações tecnológicas significativas visando atender o aumento da demanda e a entrada do setor no comércio internacional de calçados. As empresas de calçados ampliaram a parte mecânica de seu processo de fabricação de sapatos, como por exemplo, o desenvolvimento do processo de produção de calçados injetados de plástico (REICHERT, 2004, p. 52).

Até o final dos anos 80, algumas empresas de grande porte promoveram alterações na organização do trabalho, como a substituição de linhas de montagem convencionais por grupos de trabalho que eliminaram gradativamente os estoques intermediários, especialmente na seção de costura. E outras empresas instalaram minifábricas em seu layout, como forma de aumentar a variedade de produtos, reduzir o tempo de produção e melhorar a qualidade dos calçados (JÚNIOR; RUAS, 1992, p. 211) ${ }^{30}$.

Nesse período, a indústria mundial de calçados também começou a utilizar uma quantidade maior de materiais e matérias-primas alternativas ao couro, como os plásticos e tecidos, que são apresentados na tabela 9 a seguir ${ }^{31}$.

\footnotetext{
${ }^{30}$ As estratégias mais globais como Just-in-time e kanban ainda eram pouco difundidas ou se apresentam na forma de projetos para investimentos no longo prazo. Já a incorporação de componentes eletrônicos nos equipamentos - associada à necessidade de aumentar a flexibilidade dos processos produtivos e à diversificação da linha de produtos - era raramente utilizada no setor calçadista, visto que a base técnica das máquinas usadas por empresas de calçados era eletromecânica (JÚNIOR; RUAS, 1992).

${ }^{31}$ A evolução dos tipos de materiais utilizados na confecção dos calçados não determinou a substituição do couro, que ainda é a matéria-prima mais importante na produção de calçados em
} 
Tabela 9 - Evolução dos materiais utilizados na fabricação de calçados

\begin{tabular}{lccccccc}
\hline $\begin{array}{l}\text { Materiais utilizados na } \\
\text { produção de calçados }\end{array}$ & 1930 & 1940 & 1960 & 1970 & 1980 & 1990 & 2000 \\
\hline Couro natural & $\mathrm{X}$ & $\mathrm{X}$ & $\mathrm{X}$ & $\mathrm{X}$ & $\mathrm{X}$ & $\mathrm{X}$ & $\mathrm{X}$ \\
Borracha natural (não & $\mathrm{X}$ & $\mathrm{X}$ & $\mathrm{X}$ & $\mathrm{X}$ & $\mathrm{X}$ & $\mathrm{X}$ & $\mathrm{X}$ \\
vulcanizada) & & $\mathrm{X}$ & $\mathrm{X}$ & $\mathrm{X}$ & $\mathrm{X}$ & $\mathrm{X}$ & $\mathrm{X}$ \\
Borracha vulcanizada & & & $\mathrm{X}$ & $\mathrm{X}$ & $\mathrm{X}$ & $\mathrm{X}$ & $\mathrm{X}$ \\
PVC & & & $\mathrm{X}$ & $\mathrm{X}$ & $\mathrm{X}$ & $\mathrm{X}$ \\
PU & & & $\mathrm{X}$ & $\mathrm{X}$ & $\mathrm{X}$ & $\mathrm{X}$ \\
Borracha termoplástica & & & & $\mathrm{X}$ & $\mathrm{X}$ & $\mathrm{X}$ & $\mathrm{X}$ \\
PU termoplástico & & & & $\mathrm{X}$ & $\mathrm{X}$ & $\mathrm{X}$ & $\mathrm{X}$ \\
EVA & & & & & &
\end{tabular}

Fonte: Assintecal (extraído de GORINI e CORREIA, 2001).

A substituição do couro por outros insumos, em especial a partir dos anos 70 , trouxe alterações no processo produtivo e demandou novos tipos de equipamentos e sistemas de produção (máquinas de injetar solados de plástico diretamente sobre o cabedal e máquinas de montar bico e calcanheiras); novos materiais adesivos (como a cola à base de água) e de costura, bem como novas práticas para o design do produto (LEMOS; PALHANO, 2000, p. 477; GAZETA MERCANTIL, 2000a, p. 85). Entretanto, a substituição do couro por materiais sintéticos só foi possível por meio do adensamento das relações entre as empresas de calçados e a indústria química, o que tem apresentado desenvolvimentos tecnológicos relevantes para 0 desempenho dos produtos e a adoção dos novos materiais aos calçados (GARCIA, 2005) ${ }^{32}$.

A partir dos anos 90, o cenário de instabilidade econômica e o aumento da concorrência com outros produtores de calçados repercutiram no desenvolvimento da indústria de calçados, intensificando as estratégias tecnológicas e de criação de competências da cadeia. Nesse sentido, as empresas de calçados realizaram o processo de reestruturação industrial para enfrentar os efeitos da abertura econômica e da política cambial sobre o seu desempenho.

virtude de alguns atributos como a leveza, a adaptabilidade e a durabilidade desse material (GARCIA, 2006).

${ }^{32}$ O segmento de calçados esportivos pode ser destacado como exemplo dos avanços nesses materiais já que grandes empresas com produção de tênis como a Adidas e Nike têm investido sistematicamente em insumos para reduzir a temperatura e aumentar o conforto dos calçados esportivos (GAZETA MERCANTIL, 2000a, p. 85). 
$\mathrm{Na}$ esfera produtiva, as empresas investiram na adoção de novas formas de organização produtiva, na racionalização dos processos de produção ${ }^{33}$, na utilização de equipamentos mais modernos (especialmente na etapa do corte), e na intensificação da utilização de práticas de subcontratação (COSTA, 2002; GARCIA, 2004). Gorini e Siqueira (1999b) mostram em seu estudo sobre o setor que a modernização tecnológica está entre os principais fatores que afetam a cadeia industrial de calçados, o que é justificado pelo aumento de investimentos realizados na aquisição de máquinas e equipamentos.

Nesse período, a microeletrônica começou a ser difundida gradativamente nas maiores empresas, principalmente nas etapas de corte e costura onde os comandos numéricos permitem maior eficiência produtiva (VARGAS; ALIEVI, 2000, p. 436), o que contribuiu para a redução do tempo de criação dos modelos, o aumento da flexibilidade e a redução dos custos na produção de calçados (GAZETA MERCANTIL, 2000a).

As empresas de calçados passaram a apresentar avanços modestos em algumas etapas da produção de calçados por conta da mecanização do setor. As etapas de corte e modelagem, por exemplo, são as áreas que têm apresentado mais melhorias tecnológicas, e paralelamente mais dificuldades, no atendimento das variações da moda e no design, principalmente, das linhas de calçados femininos.

O nível tecnológico e o desenvolvimento inovativo do setor de calçados podem ser classificados, em grande medida, através do porte das empresas visto que a viabilidade econômica para a aplicação de processos tecnológicos é muito dependente da escala de produção, aquisição e distribuição do produto (REICHERT, 2004 , p. 54). Nesse sentido, as empresas com produção de calçados são apresentadas em três grupos:

1) Empresas de grande porte que utilizam métodos produtivos mais integrados e têm níveis tecnológicos mais avançados;

2) Empresas com patamar tecnológico relativamente mais baixo e que utilizam a mecanização de forma pouco intensiva;

\footnotetext{
${ }^{33}$ A indústria incorporou novas técnicas como Grupos de Trabalho, Just-in-time e Kanban, que permitem ganhos de qualidade e produtividade (COSTA, 1993) e requerem intensivos treinamentos e a reeducação organizacional. Mas na maioria das empresas de pequeno e médio porte, os custos dos investimentos nessas novas técnicas (poupadoras de mão-de-obra) são maiores que o uso da própria mão-de-obra, o que freqüentemente restringe a adoção homogênea dessas técnicas entre as empresas (LEMOS e PALHANO, 2000, p. 477).
} 
3) Empresas de pequeno porte, que utilizam técnicas e equipamentos defasados e são intensivos em mão-de-obra. Por conta das restrições financeiras para investimentos em tecnologias, essas empresas tendem a utilizar equipamentos usados.

Outros aspectos importantes para compreender o nível tecnológico na produção do setor são o tempo médio de utilização do maquinário e as características das atividades de manutenção das máquinas nas empresas de calçados. Em primeiro lugar, a renovação do maquinário ısado na fabricação de calçados é realizada a cada dez anos, dependendo do uso incorreto das máquinas, da qualidade e tecnologia aplicadas ao processo e principalmente das mudanças impostas pela moda - solado, cabedal, aplicações, costura e adesivos são decididos pela moda (A ROTINA..., mar-abr/05).

Muitas vezes, as novidades tecnológicas e o crescimento de pedidos fazem com que a substituição das máquinas seja mais rápida do que o previsto pela empresa usuária. Mas como o mercado de calçados é influenciado pela moda e estilos, as máquinas podem enfrentar dificuldades para se ajustar aos tamanhos de lotes e às modificações dos modelos de calçados (GAZETA MERCANTIL, 2000a).

Em segundo lugar, a atividade de manutenção tornou-se fundamental para a conservação e o uso de máquinas de todas as etapas de produção de calçados, para a incorporação de melhorias e o diagnóstico de substituição de máquinas. A principal justificativa para a realização sistemática de manutenções é a existência de maquinários com portes distintos, que funcionam a partir de comandos numéricos e realizam várias tarefas; e as mudanças tecnológicas, mesmo que incrementais, realizadas no setor de calçados.

De maneira geral, os mecânicos de manutenção das empresas de calçados, contratados ou terceirizados, reúnem habilidades especificas e uma visão de toda a produção, o que possibilita o diagnóstico e a resolução de problemas técnicos na fabricação de calçados. Em muitas empresas de calçados, a atuação desses profissionais não é mais um diferencial e sim uma necessidade das empresas que pretendem ampliar ou manter sua competitividade no mercado (PLANEJAR..., novdez/05).

Cabe ressaltar que a preservação e a manutenção dos equipamentos têm 
merecido mais atenção de empresa que trabalham com grandes lotes, como a Samello que tem uma organização rigorosa para manter a esteira em movimento ou a Mariner (Franca/SP), que trabalha com funcionários com formação profissional em mecânica e/ou em eletrônica e que conhecem o funcionamento dos equipamentos em todas as seções de produção da empresa (PLANEJAR..., nov-dez/05)

Entretanto, na maioria das empresas, principalmente de pequeno porte, a manutenção acaba acontecendo uma vez por ano, sendo comum encontrar entre as empresas, alguns casos em que não há planejamento de reparos e manutenção, até que as empresas são surpreendidas por falhas na linha de montagem.

Nesse sentido, o estágio em que se encontra o processo de fabricação de calçados, a capacitação dos operadores e mecânicos de manutenção e a assistência técnica são algumas questões que têm papel importante para o desempenho do setor de calçados (FATORES..., set-out/05).

Nos últimos anos, o setor de calçados tem investido na diversificação de mercados, na ampliação do número de linhas e modelos fabricados e na adoção (ou melhoramento) de modelos de gestão da produção visando aumentar a qualidade, reduzir os desperdícios e tornar os processos mais flexíveis COSTA, 2002).

De acordo com Garcia et al (2004), as empresas que exportam grandes volumes de produção para compradores globais - que controlam o processo de design e detêm marcas próprias - tendem a apresentar mais limitações às melhorias em produtos e processos do que as empresas com produção de calçados comercializados no mercado interno porque os compradores internacionais não têm interesse que os produtores brasileiros desenvolvam habilidades técnicas e produtivas. Nesse sentido, ao mesmo tempo em que procura adotar inovações de processos, o setor de calçados tem intensificado seus esforços na área comercial, com o fortalecimento de suas marcas - a partir de investimentos realizados em publicidade - e a consolidação de canais de distribuição de seus produtos.

As firmas têm adotado estratégias mais agressivas de desenvolvimento de produto e design visando o lançamento de novas coleções com um maior número de modelos e em prazos mais curtos e acompanhando a indústria do vestuário no 
lançamento de moda meia-estação - como forma de promover a inovação e diferenciação de seus produtos (GARCIA, 2005) ${ }^{34}$.

Mas apesar dos avanços e da modernização promovidos por empresas de vários segmentos, a forma de inserção dos produtores brasileiros de calçados no mercado internacional continua a representar um obstáculo ao desenvolvimento de competências intangíveis - aproximadamente 90\% das empresas exportadoras realiza vendas indiretas, por encomenda dos clientes, sem design e marca própria (ETIÓPIA..., ago/05). Além disso, as estratégias produtivas e comerciais não são difundidas entre os segmentos da cadeia calçadista, principalmente entre as microempresas, embora sejam relevantes para 0 seu desempenho e competitividade ${ }^{35}$.

Cabe ressaltar que as estratégias desenvolvidas pelo setor não se materializam em aumentos consistentes dos gastos com P\&D ou em indicadores expressivos no que se refere à inovação tecnológica como depósitos de pedidos de patentes (AZEVEDO, 2002; GORINI; SIQUEIRA, 1999b).

O conhecimento no interior das empresas de calçados é relativamente simples e a mudança técnica tem um caráter incremental - com o compartilhamento ocorrendo principalmente por vias informais - o que permite que, em pouco tempo, as informações estejam disponíveis para várias empresas. Nesse sentido, o grau de apropriação das tecnologias da indústria de calçados é relativamente pequeno, em função do processo de difusão das tecnologias de produção ocorrer por meio das interações e ações coletivas estabelecidas entre empresas e instituições, o que dificulta a realização de investimentos em P\&D de maneira isolada (AZEVEDO, 2002; LEMOS; PALHANO, 2000, p. 477).

Os baixos indicadores de atividade tecnológica (patentes), por sua vez, podem ser justificados pela falta de cultura quanto à utilização do Sistema de Propriedade Intelectual e pelo modo de organização do setor. De maneira geral, os

\footnotetext{
${ }^{34}$ O segmento com produção de calçados de couro, por exemplo, apresenta reduzidos investimentos em canais de comercialização, o que é justificado pelo controle das empresas nacionais por cadeias de lojas internacionais e agentes de importação (GORINI; SIQUEIRA, 1999a, p. 3).

${ }^{35}$ As instituições públicas de apoio ao setor, juntamente com o governo federal, têm desenvolvido programas de promoção à exportação de calçados com design e estilos próprios e a abertura de novos canais de distribuição, pontos estes que não serão discutidos na dissertação. Em 2005, por exemplo, a Abicalçados (Associação Brasileira das Indústrias de Calçados), em parceria com a ApexBrasil (Agência de Promoção das Exportações) promoveu a participação de estilistas brasileiros na Micam (Feira Internacional de Calçados de Milão) no programa High Fashion que apresenta trabalhos exclusivos produzidos por estilistas brasileiros (BRASIL SURPREENDE..., 27/set/2005).
} 
ganhos da proteção privada são relativamente menores que os ganhos atribuídos à interação com outras empresas e, na maioria das vezes, a proteção não é eficaz contra a exploração dos concorrentes. Por esse motivo, o setor tende a recorrer menos à mecanismos de proteção das informações tecnológicas, com exceção das etapas de design e comercialização do produto (AZEVEDO, 2002).

De acordo com Garcia et al (2005), são poucas as empresas brasileiras de calçados que gastam valores significativos em pesquisa, desenvolvimento e inovação (P\&D\&I), fator esse que as torna dependentes dos esforços inovativos de outros segmentos da cadeia de calçados. Em contrapartida, as principais empresas com fabricação de calçados do mercado internacional realizam gastos expressivos nas atividades de desenvolvimento de produto, e investem na intensificação dos contatos com fontes externas de informação, em especial com empresas de máquinas para calçados (GARCIA, 2007, p. 51-52).

Por conta desses fatores, a organização das empresas em Sistemas locais de produção, embora apresente empresas com uma diversidade de estruturas competitivas que podem dificultar o desempenho produtivo e a inovação de maneira homogênea, é o principal mecanismo para a incorporação e a criação de melhorias de produtos e processos no setor nacional de calçados.

As relações de caráter horizontal e, principalmente, vertical, entre as empresas e instituições de calçados, possibilitam não só incorporação de melhorias aos seus processos de produção e inovação - mesmo que de forma incremental mas impõe maior dinamismo às atividades externas às outras empresas e aos segmentos, que reforçam a complementaridade tecnológica e produtiva na fabricação de calçados do SLP.

Nos últimos anos, a crescente participação de outros países na produção e comércio mundial de calçados têm repercutido na dinâmica competitiva das empresas dos SLPs de calçados e nas interações verticais estabelecidas entre os segmentos, como é discutido nas próximas páginas. 


\subsubsection{O desempenho da indústria de calçados no mercado externo}

Nos últimos quinze anos, o setor calçadista brasileiro tem apresentado alterações no seu perfil de desenvolvimento industrial em virtude das modificações na estrutura de produção e comércio mundial de calçados, com a entrada de países do sul da Ásia.

Enquanto a produção e consumo aparente em pares de calçados no mercado nacional têm aumentado significativamente no mercado externo, como é apresentado na tabela 10 .

Tabela 10 - Produção e consumo interno da indústria de calçados do Brasil.

\begin{tabular}{lccccc}
\hline \multicolumn{1}{c}{ Discriminação } & 2001 & $\mathbf{2 0 0 2}$ & $\mathbf{2 0 0 3}$ & $\mathbf{2 0 0 4}$ & $\mathbf{2 0 0 5}$ \\
\hline Produção (1) & 610 & 642 & 665 & 755 & 725 \\
Consumo aparente (1) & 445 & 483 & 552 & 552 & 481 \\
Consumo per capita (2) & 2,62 & 2,84 & 2,98 & 3,02 & 2,83 \\
\hline
\end{tabular}

Fonte: Abicalçados (Resenhas Estatísticas de 2003, 2005 e 2007).

Obs: Dados estimados pela Abicalçados com base em várias fontes.

(1) Em milhões de pares. (2) Em pares.

Já no mercado externo, o Brasil ocupa a posição de $3^{\circ}$ maior produtor mundial de calçados (com 755 milhões de pares) e o $5^{\circ}$ maior mercado consumidor (com 552 milhões de pares de calçados) de acordo com os dados para o ano de 2004, como pode ser verificado nas tabelas 11 e 12 a seguir.

Tabela 11 - Principais países produtores de calçados no mundo.

\begin{tabular}{lccc}
\hline \multicolumn{1}{c}{ País } & Produção & Produção & Produção \\
$\mathbf{2 0 0 2 ( 1 )}$ & $\mathbf{2 0 0 3 ( 1 )}$ & $\mathbf{2 0 0 4}(\mathbf{1})$ \\
\hline China & $6.950,0$ & $7.800,0$ & $8.800,0$ \\
Índia & 750,0 & 780,0 & 850,0 \\
Brasil & $\mathbf{6 4 2 , 0}$ & $\mathbf{6 6 5 , 0}$ & $\mathbf{7 5 5 , 0}$ \\
Indonésia & 509,0 & 511,0 & 564,0 \\
Vietnã & 360,0 & 416,6 & 445,2 \\
\hline
\end{tabular}

Fonte: Abicalçados (Resenhas Estatísticas de 2003, 2005 e 2007).

Obs: Dados estimados pela Abicalçados com base em várias fontes.

(1) Em milhões de pares. 
Tabela 12 - Principais países consumidores de calçados no mundo.

\begin{tabular}{|c|c|c|c|}
\hline País & $\begin{array}{c}\text { Consumo } \\
2002(1)\end{array}$ & $\begin{array}{c}\text { Consumo } \\
2003(1)\end{array}$ & $\begin{array}{c}\text { Consumo } \\
2004(1)\end{array}$ \\
\hline China & $2.656,0$ & $2,782,4$ & $2.925,0$ \\
\hline EUA & $1.924,8$ & $1.997,1$ & $2.129,2$ \\
\hline Índia & 689,0 & 714,0 & 796,5 \\
\hline Japão & 585,5 & 600,0 & 620,0 \\
\hline Brasil & 483,0 & 481,0 & 552,0 \\
\hline
\end{tabular}

Fonte: Abicalçados (Resenhas Estatísticas de 2002, 2003, 2005 e 2007).

Obs: Dados estimados pela Abicalçados com base em várias fontes.

(1) Em milhões de pares .

As empresas brasileiras são grandes exportadoras mundiais de calçados, principalmente para os EUA e alguns países europeus (tabela 13), mas desde os anos 90, as vendas da indústria brasileira vêm sendo ameaçada pelo avanço dos países asiáticos nos grandes mercados consumidores do setor (GARCIA, 2005, p. 17).

Tabela 13 - Principais países exportadores de calçados no mundo.

\begin{tabular}{lccc}
\hline \multicolumn{1}{c}{ País } & Exportação & Exportação & Exportação \\
\hline China & $\mathbf{2 0 0 2 ( 1 )}$ & $\mathbf{2 0 0 3 ( 1 )}$ & $\mathbf{2 0 0 4}(\mathbf{1})$ \\
Hong Kong & $4.300,0$ & $5.026,0$ & $5.885,0$ \\
Vietnã & 771,7 & 743,3 & 744,6 \\
Itália & 333,0 & 393,0 & 420,2 \\
Brasil & 322,2 & 297,6 & 311,0 \\
\hline
\end{tabular}

Fonte: Abicalçados (Resenhas Estatísticas de 2002, 2003, 2005 e 2007).

Obs: Dados estimados pela Abicalçados com base em várias fontes.

(1) Em milhões de pares .

As principais justificativas para o crescimento da participação asiática ${ }^{36}$, em especial das empresas chinesas, na produção mundial de calçados são: desenvolvimento de escala de produção voltada para grandes volumes de produção (MDIC, 2001; GARCIA, 2005); câmbio; e vantagens de custo de mão-de-obra (salários) ${ }^{37}$.

A entrada dos países asiáticos na produção e comércio mundial de calçados resultou na redução da demanda de calçados brasileiros pelos EUA, que era o principal mercado consumidor de calçados nacional, respondendo por $70 \%$ do total

\footnotetext{
${ }^{36}$ As empresas asiáticas concentram $83 \%$ da produção mundial de calçados (COMPRADORES..., 06/abr/06). A Índia, por exemplo, é o segundo maior produtor mundial de calçados respondendo por $14 \%$ do total, o que equivale a 1,8 bilhões de pares/ano (SEGUNDO..., 15/fev/06).

${ }^{37} \mathrm{O}$ valor da mão-de-obra na China está na faixa de US\$ 0,59 por hora enquanto no Rio Grande do Sul e Nordeste, por exemplo, os custos do trabalhador ficam em mais de US $\$ 1$ e em US $\$ 0,75$, respectivamente - sem encargos sociais (CÂMBIO...,14/dez/05).
} 
de negócios em 2000 e comprava 50,15\% dos calçados do Brasil em 2005 como é apresentado na tabela 14 a seguir.

Tabela 14 - Exportações brasileiras de calçados, por países de destino.

\begin{tabular}{lrrrrrr}
\hline $\begin{array}{c}\text { Principais } \\
\text { compradores de } \\
\text { calçados do } \\
\text { Brasil (1) }\end{array}$ & $\mathbf{2 0 0 0}$ & $\mathbf{2 0 0 1}$ & $\mathbf{2 0 0 2}$ & $\mathbf{2 0 0 3}$ & $\mathbf{2 0 0 4}$ & $\mathbf{2 0 0 5}$ \\
\hline Estados Unidos & $1.078,79$ & $1.103,68$ & $1.022,94$ & 995,07 & $1.024,80$ & 946,39 \\
Reino Unido & 100,66 & 94,36 & 100,74 & 105,54 & 136,07 & 179,33 \\
Argentina & 123,38 & 132,82 & 15,76 & 72,23 & 104,65 & 112,74 \\
México & 9,30 & 21,68 & 38,51 & 50,33 & 68,67 & 57,66 \\
Espanha & 2,00 & 5,09 & 7,04 & 18,50 & 37,75 & 52,41 \\
Canadá & 33,51 & 30,15 & 37,14 & 36,26 & 50,32 & 51,00 \\
Itália & 1,20 & 2,06 & 2,24 & 4,60 & 13,87 & 40,26 \\
Chile & 20,41 & 19,67 & 20,14 & 25,41 & 34,40 & 33,34 \\
Outros & 177,50 & 205,82 & 204,39 & 241,14 & 338,89 & 413,78 \\
Total & $1.546,74$ & $1.615,34$ & $1.448,90$ & $1.549,08$ & $1.809,40$ & $1.886,91$ \\
\hline
\end{tabular}

Fonte: MDIC-SECEX, extraído de ABICALÇADOS (2007); (2006); (2003)

${ }^{*}$ ) Inclui todo o capítulo 64, exceto 64.04 (partes de calçados).

(1) Em milhões US\$.

Vale ressaltar que as empresas chinesas têm atuado em segmentos de mercado de preços mais baixo, enquanto as empresas brasileiras de calçados ocupam a faixa intermediária de preços do mercado mundial, com valores médios situados entre os preços praticados pela indústria italiana ${ }^{38}$ e os produtores de calçados da Ásia, o que representa uma oportunidade para as empresas nacionais com atuação no comércio internacional.

Para a grande maioria das empresas brasileiras de calçados de pequeno porte, o padrão de competição parece estar mais vinculado aos custos - e câmbio no caso de empresas exportadoras - e pouco às externalidades positivas decorrentes da aglomeração espacial nos sistemas locais de produção de calçados.

Entretanto, para amenizar os efeitos da concorrência externa sobre seu desempenho, muitas empresas brasileiras têm investido na diversificação dos mercados, por meio da participação em feiras ${ }^{39}$ do setor. Adicionalmente, estão

\footnotetext{
${ }^{38} \mathrm{~A}$ indústria italiana apresenta elevada capacidade de desenvolvimento de produto e design, e por esse motivo ocupa as faixas superiores do mercado, em que o preço médio é bastante elevado e os volumes são reduzidos. Além disso, as empresas italianas têm adotado estratégias de subcontratação da produção em países com menores custos de trabalho (Turquia, Romênia, entre outros) visando à redução dos seus custos de produção.

${ }^{39}$ A MICAM 2007 (Feira Internacional de Calçados de Milão), por exemplo, contou com participação de 36 marcas nacionais de calçados representadas pelo Brazilian Footwear - Programa de Promoção às Exportações, desenvolvido pela Abicalçados com o apoio da Apex-Brasil - que estão apostando em mercados de maior valor agregado, como o Japão (MICAM..., 21/set/07). De acordo com levantamento da Abicalçados, os pedidos gerados na última edição da feira, realizada em setembro,
} 
intensificando o desenvolvimento de novos canais de comercialização como mecanismo para não competir diretamente com os calçados chineses ${ }^{40}$.

É importante destacar que a competitividade das empresas de calçados nacionais nos últimos anos - em especial nas regiões de Novo Hamburgo (RS) e Franca (SP) - frente os concorrentes de outros países foi possível, em grande medida, por conta dos sistemas de relações estabelecidos entre as empresas e segmentos do setor.

Mesmo a reestruturação industrial e as mudanças nas tecnologias e processos do setor de calçados só puderam repercutir, de fato, na competitividade das empresas por conta da integração entre os sistemas de produção e de conhecimento no interior dos SLPS - a partir das interações intrafirmas entre empresas de máquinas e os usuários da cadeia calçadista - que determinaram um cenário de aprendizado incremental de caráter contínuo, sendo considerada uma das forças que puxam o desenvolvimento competitivo dos SLPs. Contudo, as modificações na produção e comércio mundial de calçados, assim com as flutuações macroeconômicas que interferem diretamente na demanda do setor nacional de calçados tem repercutido no desenvolvimento industrial e tecnológico da indústria, principalmente no segmento de máquinas para calçados e nas suas relações com os segmentos da indústria calçadista.

\subsection{O setor de máquinas para couro e calçados}

O setor de máquinas para a indústria de calçados é formado por 132 empresas, a maioria de pequeno e médio porte e de capital nacional, segundo dados de 2007 da Associação Brasileira da Indústria de Máquinas para Couro,

somaram cerca de US $\$ 7,6$ milhões, contra US $\$ 2,5$ milhões em 2006, o que pode sinalizar o aumento dos esforços entre as empresas de grande porte para o fortalecimento das marcas no exterior (EMPRESAS..., 25/set/07). Além disso, a ABICALÇADOS com ao apoio da APEX (Agência de Promoção de Exportações) também iniciou um programa voltado à participação de empresas brasileiras em feiras do mercado consumidor da China - Hong Kong, Pequim, Xangai e Guangzhu com a participação de 15 empresários do setor calçadista (BRASIL. CONTRA-ATACA..., 26/set/2007).

${ }^{40}$ Uma prova disso é que o número de países que comercializam os calçados brasileiros aumentou de 85 no ano de 1989 para 135 países em 2002, representando um crescimento de 58\% segundo pesquisa realizada pela revista Courobusiness de setembro de 2003 (CALÇADO...,18/set/03) 
Calçados e Afins (ABRAMEQ, 2007).

$\mathrm{Na}$ última década, o setor apresentou significativas variações no número de empresas e de empregos: em 1997, por exemplo, o setor tinha 65,15\% do total de empresas que estão em atividade hoje, mas têm recuperado a sua média nos últimos anos. Já o número de funcionários tem caído sistematicamente desde 0 início da década passada: em 2000, por exemplo, o total do quadro de funcionários representou $18 \%$ do total empregado pelo setor em 1993, como pode ser verificado na tabela 15 a seguir.

Tabela 15 - Número de empresas e de funcionários do setor de máquinas para couro e calçados.

\begin{tabular}{ccccc}
\hline Ano & $\begin{array}{c}\text { Número de } \\
\text { empresas }\end{array}$ & $\begin{array}{c}\text { Crescimento do } \\
\text { número de } \\
\text { empresas (\%) }\end{array}$ & $\begin{array}{c}\text { Número de } \\
\text { funcionários }\end{array}$ & $\begin{array}{c}\text { Crescimento do } \\
\text { número de } \\
\text { funcionários (\%) }\end{array}$ \\
\hline 1993 & 138 & - & 15.000 & - \\
1994 & 138 & 0,0 & 13.600 & $-9,3$ \\
1995 & 120 & $-13,0$ & 10.800 & $-20,6$ \\
1996 & 102 & $-15,0$ & 9.750 & $-9,7$ \\
1997 & 86 & $-15,7$ & 4.200 & $-56,9$ \\
1998 & 86 & 0,0 & 2.687 & $-36,0$ \\
1999 & 99 & 15,1 & 2.562 & $-4,7$ \\
2000 & 113 & 14,1 & 2.809 & 9,6 \\
\hline
\end{tabular}

Fonte: ABRAMEQ, disponível em AZEVEDO (2002); ABRAMEQ (06/abril/2007).

As empresas de máquinas estão localizadas no Rio Grande do Sul (112), e nos Estados de São Paulo (14), Santa Catarina (3) e Paraná (3) (ABRAMEQ, 2007) 41 . Os principais pólos de produção de calçados estão organizados no Vale do Rio dos Sinos (RS) e em Franca (SP), que concentram 95\% do total de empresas nacionais do setor de máquinas.

O principal destino da produção de máquinas brasileiras é o mercado interno (85\%) enquanto o restante (15\%) é vendido para outros países, em especial para os países da América Latina e o México (EXPORTAÇÕES BRASILEIRAS DE MÁQUINAS CRESCEM 130..., mar-abr/04).

A origem do setor de máquinas nos dois principais pólos de produção de calçados (Vale do Sinos e Franca) pode ser explicada pelo surgimento de oficinas de

\footnotetext{
${ }^{41}$ A Associação Brasileira de Máquinas para Couro, Calçados e Afins (ABRAMEQ) foi criada em 1992 para fomentar o desenvolvimento tecnológico e comercial do setor e tem sido um dos principais órgãos de apoio e promoção das empresas de máquinas. Atualmente a entidade é representante de 50 empresas de máquinas para couro e calçados localizadas em Novo Hamburgo (RS), Franca (SP), Santa Catarina e Paraná (ABRAMEQ, 2007).
} 
manutenção de equipamentos para atender à expansão das atividades de curtume e de produção de calçados a partir dos anos 40 (VARGAS; ALIEVI, 2000; TATSCH, 1995).

O auge do desenvolvimento do setor ocorreu a partir dos anos 70, com o crescimento da demanda por máquinas para calçados visando o atendimento de pedidos de calçados para o mercado externo (AZEVEDO, 2002). Nesse período, as empresas nacionais de máquinas atuavam, principalmente, como revendedoras de peças e na prestação de serviços das empresas estrangeiras.

Até o final dos anos 80 , a mecanização do setor era realizada principalmente por meio da importação de máquinas, o que dificultava o crescimento da indústria uma vez que as oscilações na taxa de câmbio prejudicavam a entrada de produtos e peças vindos de outros países (RUFFONI, 2004). Além disso, a redução das alíquotas de importação de bens de capital refletiu no dinamismo do setor de máquinas para calçados, uma vez que as empresas não contavam com a proteção à concorrência de outros países.

$\mathrm{Na}$ década de 90, a abertura da economia ao comércio internacional dificultou a participação das empresas brasileiras de máquinas no mercado interno e externo. A maioria das empresas investiu na reestruturação produtiva por meio da otimização de seus processos - houve um aumento do número de subcontratações em algumas etapas de fabricação de máquinas, como as atividades de usinagem redução do número de funcionários e a ampliação do conteúdo tecnológico das máquinas (VARGAS; ALIEVI, 2000, p. 454). Adicionalmente, as empresas passaram a adotar três estratégias visando a sua atualização tecnológica: acordos e parcerias com empresas estrangeiras, principalmente com as empresas italianas; interações com os usuários do mercado interno; e participação em feiras e eventos internacionais do setor.

Em primeiro lugar, as parcerias realizadas com concorrentes de outros países estão voltadas à incorporação de inovações tecnológicas que são adaptadas às necessidades dos clientes no mercado interno, constituindo uma importante fonte de informação externa do setor (VARGAS; ALIEVI, 2000; SILVA, 2003; GARCIA, 2006).

O mercado nacional de máquinas para calçados sempre apresentou uma significativa participação dos fornecedores de máquinas da Itália, que são referência mundial em termos de tecnologias, seguida pelas máquinas alemãs e as inglesas 
(RUFFONI, 2004).

Até a década de 90 , essas empresas estrangeiras de máquinas foram beneficiadas por políticas de liberalização das importações nacionais, que resultaram no crescimento significativo da participação de máquinas provenientes de outros países. Na última década, algumas empresas nacionais intensificaram acordos para a representação comercial dos produtos estrangeiros, como pode ser verificado abaixo (Quadro 6), porque consideravam que esse mecanismo poderia ajudar no aumento das exportações e no aprendizado de novas tecnologias para as máquinas nacionais.

\begin{tabular}{|c|c|}
\hline Empresas & Parcerias \\
\hline Ivomaq & $\begin{array}{l}\text { - Parceria em } 2002 \text { com a empresa Ciucani. A partir do acordo, a } \\
\text { empresa brasileira terá acesso à tecnologia italiana e poderá produzir } \\
\text { similares nacionais a custos mais acessíveis para a indústria calçadista } \\
\text { (14 modelos da linha italiana serão incorporados à produção da } \\
\text { Ivomaq). A empresa estrangeira, por sua vez, poderá ampliar sua } \\
\text { participação em novos nichos do mercado externo (ACORDO..., fev/03). }\end{array}$ \\
\hline Kehl & $\begin{array}{l}\text { - Firmou acordo com a empresa italiana Sicom, para atuar como } \\
\text { importadora e revendedora de máquinas (Gazeta Mercantil, 2000) e } \\
\text { para incluir em sua linha de produção, a máquina automática de aplicar } \\
\text { botões para calçados e confecções. } \\
\text { - Outro acordo foi iniciado em } 1999 \text { para a distribuição do sistema CAD- } \\
\text { CAM da Elitron - usado na criação e modelagem de calçados - } \\
\text { visando o direito de comercialização exclusiva (e assistência técnica) do } \\
\text { produto estrangeiro no Brasil e na América Latina (INDÚSTRIA DE } \\
\text { MÁQUINAS..., 20/mai/00). }\end{array}$ \\
\hline Master & $\begin{array}{l}\text { - Concluiu em abr/2000 uma joint venture com a empresa italiana } \\
\text { Eurocomat, para a transferência de tecnologia (INDÚSTRIA DE } \\
\text { MÁQUINAS..., 20/mai/00). } \\
\text { - Acordo em } 2004 \text { com a empresa italiana Matic, para a produção de } \\
\text { máquinas de pregar saltos (modelo VR-51), visando a incorporação de } \\
\text { novas tecnologias e o aumento das vendas no mercado interno e } \\
\text { externo (ACORDO UNE..., mai/04). }\end{array}$ \\
\hline Metal & $\begin{array}{l}\text { - O primeiro acordo foi estabelecido em } 2000 \text { com a empresa italiana } \\
\text { Sirem, para a produção de uma linha de cabines para pintura de } \\
\text { solados automatizada, utilizada inclusive no exterior (NOVAS..., fev/03). } \\
\text { - Acordo firmado com a empresa alemã Ring RKK para o } \\
\text { desenvolvimento conjunto da Vaporizadora Vap Press, que umecta e } \\
\text { expande o couro (NOVAS..., fev/03). A partir desse acordo, a empresa } \\
\text { gaúcha também passou a comercializar suas máquinas de secagem de } \\
\text { adesivo a base d'água na Alemanha (INDÚSTRIA DE MÁQUINAS..., } \\
\text { 20/mai/00). } \\
\text { - Outro acordo com a empresa Zipor S.A., de Portugal, para a venda e } \\
\text { distribuição de máquinas para corte de cabedais à jato d água } \\
\text { (INDÚSTRIA DE MÁQUINAS..., 20/mai/00). }\end{array}$ \\
\hline
\end{tabular}


Continuação

\begin{tabular}{|c|c|}
\hline Empresas & \multicolumn{1}{c|}{ Parcerias } \\
\hline Poppi & $\begin{array}{l}\text { Parceria em 1982 com a empresa italiana Molina \& Bianchi, visando a } \\
\text { transferência de tecnologias para a produção de máquinas de montar } \\
\text { bico. }\end{array}$ \\
\hline
\end{tabular}

Fonte: Pesquisa documental (várias fontes).

Quadro 6 - Parcerias entre algumas empresas nacionais de máquinas e os concorrentes do mercado externo.

Recentemente, algumas empresas brasileiras de máquinas para calçados mantêm parcerias com empresas italianas, em grau bem menor que nos anos anteriores, como forma de adequar as tecnologias estrangeiras e aumentar as exportações, principalmente no segmento de máquinas para couro (ABRAMEQ, 2005).

Em segundo lugar, as empresas de máquinas intensificaram as interações com os usuários da cadeia, com o objetivo de desenvolver capacitações específicas para os consumidores do mercado nacional que, freqüentemente, não encontram máquinas com tecnologias similares e a baixos custos entre os produtores de máquinas de outros países.

No início da década de 90, a empresa gaúcha Máquinas Klein, por exemplo, buscava o desenvolvimento de novos projetos e contava com o levantamento de dados junto aos usuários; a confecção de anteprojeto; e a reprodução exata da máquina em tamanho natural, mas em material mais barato, visando a facilidade nos ajustes de design e ergonomia. Outras empresas como a ERPS, Irmãos Zambelli, Máquinas Sazi e Himaco ressaltavam as estratégias de levantamento de dados considerando as especificidades dos produtores e as diferenças regionais e no uso de materiais, que se tornaram fundamentas para a evolução tecnológica das empresas e do setor (EVOLUÇÃO..., abr/93).

Um aspecto importante para compreender essas relações é o preço das máquinas e o volume (da produção de calçados) necessário para justificar a aquisição das máquinas.

De maneira geral, entre as empresas usuárias de pequeno porte, a sazonalidade das linhas de calçados impede a diluição dos investimentos com maquinário no curto prazo e dificultam a incorporação de equipamentos mais modernos e caros. Por esse motivo, a introdução de tecnologias mais avançadas 
nas máquinas é realizada mais por empresas locais que consideram as características e necessidades específicas dos usuários e incorporam as melhorias às suas linhas de produtos (RUFFONI, 2004).

Já as empresas de calçados de grande porte, por sua vez, tendem a apresentar uma demanda relativamente maior por máquinas estrangeiras, porque os fornecedores de outros países apresentavam modelos com alto grau de incorporação de componentes microeletrônicos e elevada eficiência, relativamente às máquinas brasileiras, e seus produtos eram vendidos a preços mais atrativos e com boas condições de financiamento para os consumidores do mercado interno. (GORINI; SIQUEIRA, 1999b, p. 33).

O terceiro mecanismo utilizado para a modernização do setor é a participação das empresas de máquinas para calçados em eventos internacionais para a prospecção de novos clientes e as melhorias de sua competitividade no mercado externo. Adicionalmente, as empresas nacionais também investem na participação em feiras visando o aprendizado de novas tecnologias incorporadas nos produtos de empresa concorrentes do setor.

De acordo com a ABRAMEQ (2007b), as empresas de calçados trabalham com lotes cada vez menores e linhas de calçados diversificadas, o que reflete na baixa atualização do maquinário e tem forçado as empresas brasileiras de máquinas a buscar novos clientes em outros países, principalmente na América Latina.

Por um lado, essa forma de atuação no mercado externo tem contribuído para o aumento das vendas e a melhoria da competitividade das empresas nacionais de máquinas. Além disso, o contato com novos usuários, freqüentemente, fortalece a interdependência entre os sistemas de produção e de conhecimentos no interior dos SLPs porque as empresas incorporam novas maneiras para lidar com problemas técnicos na fabricação de calçados e ampliam as habilidades voltadas à adaptação de produtos. Nesse sentido, a base organizacional para a aquisição e geração de conhecimentos das empresas de máquinas tende a se tornar mais aberta e os sistemas locais de produção mais dinâmicos.

Por outro lado, a participação das empresas de máquinas em outros mercados não possibilita o aprendizado de novos produtos porque, muitas vezes, as empresas nacionais precisam retirar parte dos componentes tecnológicos de suas 
máquinas $^{42}$. Porém, a participação nos mercados interno e externo impõe às empresas de máquinas também a necessidade de trabalhar e adaptar-se em mercados com patamares tecnológicos bastante heterogêneos, reforçando as competências tecnológicas do SLP.

É importante considerar que a concorrência no mercado interno de máquinas é mais forte entre grupos de empresas especializadas nas mesmas famílias de produtos (RUFFONI, 2004), mas de maneira geral, as empresas fabricam máquinas com características complementares para a produção de calçados, o que facilita a integração em feiras internacionais do setor e o adensamento dos SLPs de Novo Hamburgo e Franca (ABRAMEQ, 2007b).

No período recente, a organização das empresas em arranjos produtivos promoveu o adensamento da cadeia e a especialização e domínio das tecnologias no interior do SLP. Porém, ao mesmo tempo pode restringir a atuação e o desempenho das empresas de máquinas porque dificulta a sua atuação em outros segmentos de mercado: enquanto o segmento de componentes, por exemplo, consegue diversificar mais e por isso tem um perfil competitivo diferente; o setor de máquinas para calçados, por outro lado, está preso ao desempenho e à demanda das empresas de calçados (ABRAMEQ, 2007b).

De acordo com dados do MDIC (2001), um dos principais gargalos para o desenvolvimento do setor de máquinas é o atendimento das condições de crédito, em especial no caso das empresas de pequeno e médio porte: o nível de informalidade e a falta de garantias reais fazem com que os principais canais formais de fomento sejam relativamente pouco utilizados nas empresas. Mesmo as iniciativas como fundos de aval ainda têm alcance limitado para as empresas de pequeno porte (MDIC, 2001, p. 52) porque foram concebidos sem conhecer o real funcionamento do setor: as exigências burocráticas desses fundos dificilmente podem ser atendidas e as taxas de juros embutidas nos empréstimos são financeiramente inviáveis para as empresas de pequeno porte.

A carência de recursos humanos especializados em automação industrial e nas operações de máquinas-ferramenta com comando numérico computadorizado também pode dificultar o desempenho das empresas de máquinas. Isso ocorre

\footnotetext{
${ }^{42} \mathrm{Na}$ Colômbia, por exemplo, que é o terceiro maior cliente do Brasil, muitas vezes as máquinas têm que apresentar tecnologias mais simples seja para reduzir o preço dos produtos ou porque os usuários colombianos não têm as capacitações para utilizar tecnologias mais avançadas.
} 
mesmo estando as principais empresas produtoras localizadas proximamente a importantes pólos metal-mecânico, que fazem uso intenso desta qualificação da mão-de-obra e que contam com a participação de instituições como SENAI e escolas técnicas regionais (AZEVEDO, 2002, p. 52; MDIC, 2001, p. 25).

A proximidade com todos os segmentos da cadeia facilita o acesso à novas tecnologias, porém entre aquelas empresas que utilizam a base microeletrônica ou hidráulicos, há carências de cursos de atualização tecnológica. Algumas empresas de máquinas para calçados da região sul, por exemplo, recorrem, freqüentemente, à cursos (ou palestras) oferecidos por fornecedores de componentes eletrônicos do SLP ou de outros Estados (como São Paulo) visando a atualização técnica de seus funcionários.

Recentemente, o setor também tem discutido problemas relativos à segurança na utilização das máquinas para a fabricação de calçados e à padronização no uso de ferramentas mais seguras destinadas ao mercado interno e externo. No SLP do Rio Grande do sul, por exemplo, os representantes das empresas de máquinas enfatizam modificações no desenvolvimento de produtos por conta das exigências da Delegacia Regional do Trabalho por equipamentos com dispositivos de segurança ${ }^{43}$ : enquanto uma parte das empresas do setor de calçados exige a retirada desses dispositivos, priorizando o aumento da produtividade; em outras empresas, não há essa preocupação maior com os custos e produtividade na fabricação de calçados $^{44}$. Nesse sentido, as empresas de máquinas do SLP do sul não enfrentam dificuldades para comercializar seus produtos com ou sem os dispositivos de segurança no mercado interno ou externo.

É importante considerar que a dinâmica industrial e as dificuldades enfrentadas pelo setor de máquinas para couro e calçadas nos últimos anos determinaram o desenvolvimento tecnológico distinto entre os segmentos de máquinas para a fabricação de calçados, como será apresentado na próxima seção.

\footnotetext{
${ }^{43}$ No SLP do Vale do Sinos, a Associação Comercial da Indústria $(\mathrm{ACl})$ em conjunto com a ABRAMEQ, realizaram diagnósticos das condições das máquinas utilizadas por algumas empresas de calçados e constataram, entre outros fatores, que é comum entre as empresas de pequeno porte, a aquisição de máquinas recondicionadas muito antigas e a retirada dos dispositivos de segurança dos equipamentos antigos e novos, o que amplia as chances para acidentes de trabalho (FABRICANTES..., 14/out/04).

A partir de 2003, a Delegacia Regional do Trabalho e a ABRAMEQ começaram um trabalho de conscientização junto aos fabricantes de calçados e de máquinas, visando a homogeneização na incorporação de dispositivos de segurança.
} 


\subsubsection{Desenvolvimento tecnológico das máquinas para calçados}

O setor de máquinas para calçados apresenta um perfil bastante heterogêneo em termos de especialização da produção, conforme o segmento que se destinam, sendo as mais complexas aquelas voltadas à preparação de borracha, de injeção de materiais termoplásticos e de curtumes (MDIC, 2001, p. 22).

O processo de produção de calçados envolve de 120 a 130 operações, sendo que em média 70\% delas são mecanizadas (GAZETA MERCANTIL, 2000b, p. 74; CROCCO et al, 2000, p. 23) ${ }^{45}$.

As empresas brasileiras de máquinas apresentam alto nível de diversificação tecnológica: em geral, uma empresa chega a produzir muitos tipos diferentes de máquinas para cada família de produtos (GAZETA MERCANTIL, 2000b, p. 74). Além disso, embora grande parte das empresas apresente alguns modelos de máquinas seriadas, o setor produz principalmente sob encomenda - a produção seriada é difícil para o setor porque os projetos são desenvolvidos sempre em função das necessidades dos clientes.

Os tipos de máquinas para calçados e as características das tecnologias em cada etapa de produção de calçados são apresentados no quadro 7 :

\begin{tabular}{|l|l|}
\hline $\begin{array}{c}\text { Etapas de produção } \\
\text { de calçados }\end{array}$ & \multicolumn{1}{|c|}{ Tecnologias e máquinas utilizadas em cada etapa } \\
\hline \multirow{1}{*}{ Design e Modelagem } & $\begin{array}{l}\text { A modelagem é o ponto de partida para a criação do calçado, podendo ser realizada } \\
\text { manualmente (por meio de pantógrafo, que faz a escala e corta em cartolina) ou } \\
\text { automatizada (com recursos CAD-CAM). Entre os benefícios e desvantagens de } \\
\text { ambos - manual e informatizado - pode-se destacar que no primeiro, o funcionário } \\
\text { pode utilizar suas habilidades, mas perde em termos de produtividade. Já a } \\
\text { modelagem informatizada facilita a interpretação das idéias e evita correções futuras, } \\
\text { mas perde na habilidade dos modelistas que é pouco explorada (MODELAGEM..., } \\
\text { mar-abr/05). }\end{array}$ \\
& $\begin{array}{l}\text { A etapa de criação e modelagem incorpora equipamentos eletrônicos como o o } \\
\text { Projeto Assistido por Computador (CAD - Computer Aided Design) e a Manufatura } \\
\text { Assistida por Manufatura (CAM - Computer Aided Manufacturing) que são acoplados } \\
\text { ao processo de produção de calchados, permitindo maior agilidade no no } \\
\text { desenvolvimento dos produtos, a produtividade na fabricação e a minimização de } \\
\text { desperdícios (GARCIA, 2005). }\end{array}$ \\
\hline
\end{tabular}

Continua

\footnotetext{
45 A etapa de elaboração de uma sola em couro, por exemplo, utiliza cerca de nove tipos de máquinas (Gazeta Mercantil, 2000b, p. 74).
} 
Continuação

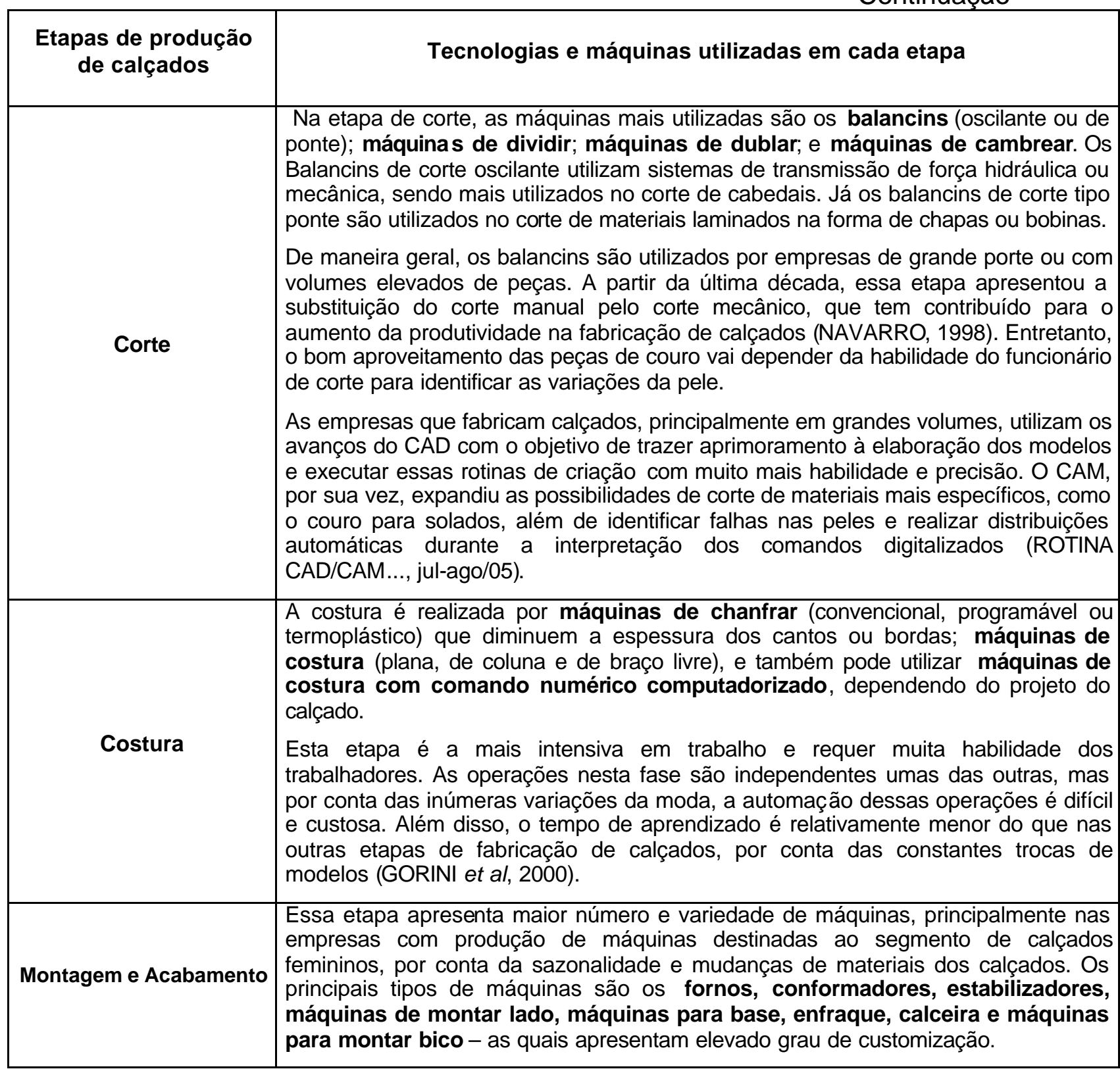

Fonte: Navarro (1998); Garcia (2005a); Gorini et al (2000); Revista Passarela n. 19 e 21.

Quadro 7 - Tecnologias e máquinas utilizadas na produção de calçados (por etapa)

As empresas de máquinas para o setor de calçados apresentam um baixo grau de modernização no que se refere à incorporação de tecnologias, especialmente quanto aos componentes microeletrônicos (GORINI; SIQUEIRA, 1999a, p. 18). A principal justificativa para essa característica é que como a indústria apresenta elevada disponibilidade de mão-de-obra e atividades intensivas em recursos humanos, a incorporação da microeletrônica não era considerada um atributo necessário e economicamente viável para a cadeia calçadista até meados dos anos 80 . 
A partir desse período, os principais fabricantes de máquinas começaram a produzir equipamentos com componentes microeletrônicos que podem ser usados em quase todas as etapas de fabricação de calçados - máquinas de pintura de couro, sistemas para corte, máquinas de costura e de bordado computadorizadas e máquinas destinadas à etapa de montagem, como as máquinas eletrônicas de apontar e montar bico (RUFFONI, 2003).

Atualmente, a indústria de máquinas tem demonstrado capacidade para realizar o atendimento de demandas específicas da indústria de calçados e, a partir desse atendimento, tem incorporado melhorias aos seus modelos de máquinas, o que tem representado um elemento de proteção dessa indústria frente aos seus concorrentes internacionais, especialmente italianos (GARCIA, 2005, p. 34).

Entre os avanços mais importantes das empresas de máquinas para 0 desempenho do setor calçadista, pode-se destacar a adaptação de novos materiais plásticos para a fabricação de calçados; a introdução de adesivos a base de água, em substituição àqueles baseados em solvente (material mais tóxico); e a incorporação de componentes microeletrônicos em máquinas e equipamentos (GARCIA, 2005, p. 32).

Uma mudança significativa para o processo de fabricação de calçados é a incorporação de Sistemas CAD/CAM nos processo de injeção de materiais termoplásticos, seja o processo compacto (realizados por máquinas estáticas) ou expandido (realizados por máquinas rotativas). O que se verifica é que com o gerenciamento online, as máquinas estáticas para injetados passaram a apresentar condições para processar também materiais expandidos, determinando maior versatilidade ao segmento de máquinas para injetados ${ }^{46}$.

$\mathrm{Na}$ etapa de montagem, as máquinas de montar bico também apresentaram inúmeras modificações nas últimas décadas, com a disponibilização de componentes hidráulicos, pneumáticos, elétricos e eletrônicos, o que contribuiu muito para o processo de fabricação de qualquer tipo de calçado e com a redução do tempo de set up.

Os sistemas hidráulicos ou pneumáticos apresentam o sincronismo de funcionamento - controlado eletronicamente - possibilitando a montagem de

\footnotetext{
${ }^{46} \mathrm{Na}$ área de matrizaria, por sua vez, a Universidade Federal de Santa Catarina (UFSC) desenvolveu um projeto CAD/CAM para a confecção de moldes injetados, que podem gerar, automaticamente, todas as escala a partir de um número padrão (TECNOLOGIA..., set-out/99).
} 
cabedais com menor consumo de materiais; Já as máquinas com controle computadorizado, por sua vez, podem realizar todos os movimentos através de um monitor que apresenta as informações de programação em páginas de fácil acesso e visualização, o que facilita as alterações rápidas no funcionamento das máquinas (TECNOLOGIA EM..., jul/02).

Um aspecto importante do desenvolvimento tecnológico das empresas de máquinas é que apesar de ter desenvolvido capacidades de engenharia de projetos para lidar com os requisitos dos clientes, as empresas apresentam pequena capacidade de desenvolvimento (P\&D). A maioria das empresas de pequeno e médio porte trabalha sem capital de giro, o que inviabiliza iniciativas voltadas à pesquisa e desenvolvimento de novas capacitações. Mesmo entre as empresas de médio porte que estão criando capacitações, esse processo é bastante heterogêneo por conta da maior defasagem tecnológica em alguns segmentos e porque o próprio processo de fabricação de calçado - intensivo em mão-de-obra - dificulta a automação em algumas etapas.

Adicionalmente, pode-se encontrar no setor de máquinas, de um lado, empresas que são fornecedoras de máquinas commoditizadas - máquinas de costura, injetoras e balancins (mais simples) - que têm sua competitividade explicada, fundamentalmente, pelo preço dos produtos e apresentam maior concorrência com empresas de máquinas do mercado externo. De outro lado, há empresas com produção de máquinas customizadas - máquinas das etapas de montagem - com esforços tecnológicos mais significativos e competitividade atribuída ao desempenho dos produtos, podendo contribuir para o dinamismo do setor no mercado nacional.

Em ambos os casos - produtos commoditizados ou customizados - as empresas brasileiras de máquinas para calçados apresentam flexibilidade técnica e habilidades que possibilitam a incorporação de melhorias e a resolução de problemas em empresas de calçados com os vários níveis de desenvolvimento tecnológico. Adicionalmente, os serviços de assistência técnica oferecida às empresas de calçados constituem um importante instrumento de acesso às informações de produto e de mercado.

Nos últimos anos, as empresas de máquinas para calçados têm apresentado alterações no seu desempenho, principalmente no mercado externo, por conta da crescente participação de empresas asiáticas no comércio internacional de 
máquinas para couro e calçados, como será discutido nas próximas páginas.

\subsubsection{As mudanças no mercado internacional de máquinas para calçados}

A produção e as vendas dos segmentos de bens de capital são influenciadas por flutuações das taxas de investimento, que refletem diretamente no nível de utilização da capacidade instalada da indústria e nas expectativas quanto ao desempenho futuro da economia. Entretanto, no ramo de máquinas para a cadeia de calçados, não são os fluxos de investimentos da economia que interferem no desempenho dos segmentos de máquinas para calçados, embora esses investimentos contribuam indiretamente para o dimensionamento da produção do setor.

O desempenho das empresas de máquinas para calçados no comércio internacional varia em função das necessidades de abastecimento dos seus usuários no mercado nacional e estrangeiro, o que diferencia essa indústria dos demais segmentos de bens de capital.

No ano de 1993, por exemplo, o setor de máquinas para calçados apresentou um boom de exportações com US\$ 47 milhões, o maior valor de todos os tempos, como resultado do crescimento da demanda do setor de calçados. Entretanto, ainda nesse período, o setor entrou num processo de declínio de suas vendas no mercado interno e externo, e em alguns casos, apresentou conflitos com as empresas calçadistas nacionais que passaram a comprar máquinas de outros países.

No mercado interno, a redução das taxas de importações de máquinas e componentes e os incentivos do governo italiano aos exportadores de máquinas tornaram a produção brasileira relativamente mais cara que a importação de máquinas (NARGAS; ALIEVl, 2000, GAZETA MERCANTIL, 200b). Nesse sentido, muitas empresas nacionais (principalmente de grande porte) passaram a contornar a "lei do similar nacional" que restringia e taxava a importação de equipamentos que contassem com equivalente nacional (VARGAS; ALIEVI, 2000, p. 442). As exportações, por sua vez, apresentaram considerável queda que pode ser explicada pela sobrevalorização da moeda a partir de 1994.

Em meados dos anos 90, diante das dificuldades para concorrer com os 
produtos estrangeiros importados, e por conta das políticas macroeconômicas que limitavam a inserção das máquinas nacionais para couro e calçados em outros mercados, o setor reestruturou suas atividades produtivas, acentuando a subcontratação de algumas etapas realizadas internamente, e em alguns casos, diversificando o mercado de atuação para reduzir a dependência da demanda interna.

Desde o final da década de 90, o setor tem apresentado o crescimento significativo das vendas destinadas ao mercado externo, como pode ser verificado na tabela a seguir ${ }^{47}$.

Tabela 16 - Evolução das exportações brasileiras de máquinas para couro e calçados.

\begin{tabular}{ccc}
\hline Ano & $\begin{array}{c}\text { Exportações } \\
\text { (US\$ FOB) }\end{array}$ & $\begin{array}{r}\text { Crescimento das } \\
\text { exportações (\%) }\end{array}$ \\
\hline 1998 & 3.757 & - \\
1999 & 3.509 & $-6,6$ \\
2000 & 5.153 & 46,9 \\
2001 & 5.498 & 6,7 \\
2002 & 7.904 & 43,8 \\
2003 & 8.564 & 8,4 \\
2004 & 13.660 & 59,5 \\
2005 & 11.701 & $-14,3$ \\
2006 & 12.431 & 6,2 \\
\hline
\end{tabular}

Fonte: ABRAMEQ. Disponível em: http://www.abrameq.com.br/. Acesso em 10/abril/07.

No ano de 2004, por exemplo, a indústria de máquinas para couro e calçados apresentou o melhor desempenho da última década, com exportações de US\$13.6 milhões. As máquinas para calçados contribuíram com US\$11,1 milhões das vendas externas, destinadas para o total de 32 países - o México foi o principal consumidor, com compras de US\$ 4,4 milhões, seguido pela Argentina (US\$ 2,9 milhões) e o Chile (US\$ 821 mil). Já o segmento de máquinas para curtumes, foi responsável por US\$2,5 milhões em máquinas vendidas para 18 países, em especial para o Uruguai (US\$ 646 mil) e o mercado mexicano (US\$ 626 mil) (EXPORTAÇÕES BRASILEIRAS...,13/abr/05).

$\mathrm{O}$ desempenho exportador das empresas de máquinas para couro e calçados pode ser explicado, em grande medida, por inúmeros esforços visando a adequação das máquinas aos padrões internacionais de comercialização e a

\footnotetext{
${ }^{47}$ Atualmente, o setor de máquinas tem conseguido aumentar suas exportações, principalmente em segmentos de menor valor (AZEVEDO, 2002, p. 49), e tem contado com a participação dos países da América Latina (Colômbia, Peru, Argentina e Venezuela), do México e da Índia para o fornecimento de seus produtos (ABRAMEQ TRARÁ VISITANTES..., 27/mar/06).
} 
inserção das empresas brasileiras em novos mercados.

$\mathrm{Na}$ área de desenvolvimento de produtos, o setor de máquinas está investindo na consolidação do selo By Brasil que é uma certificação de qualidade das máquinas, tendo por base as exigências mundiais para a comercialização destes (EXPORTAÇÕES BRASILEIRAS DE MÁQUINAS CRESCEM $60 \ldots, 13 / a b r / 05)$.

Entretanto, alguns segmentos da cadeia de calçados como o segmento de componentes tem incorporado mais a idéia de certificação do que as empresas de máquinas $^{48}$. A principal justificativa apontada pela ABRAMEQ é que a maioria das empresas (de máquinas) não percebeu o benefício que a certificação pode trazer para o seu desempenho no mercado externo; e grande parte delas considera que para se adequar às exigências requeridas para a certificação teria que mudar toda a linha, o que geraria muitos custos: em 2007, por exemplo, apenas cinco empresas de máquinas para calçados aderiram ao selo By Brasil (ABRAMEQ, 2007b).

$\mathrm{Na}$ área comercial, desde meados dos anos 90 a ABRAMEQ, com o apoio financeiro da APEX, tem apresentado vários programas de fomento e incentivo à participação do setor de máquinas para couro e calçados em outros mercados.

Em 1998, a ABRAMEQ e a APEX desenvolveram o Programa Setorial Integrado com investimentos na ordem de $\mathrm{R} \$ 5$ milhões visando a promoção das exportações de máquinas para couro e calçados (MDIC, 2001) a partir de visitas à feiras internacionais do setor (LIVRE..., mar/99). O Programa Setorial foi renovado para os próximos dois anos, contando com investimentos de $R \$ 4,5$ que estarão voltados à inserção comercial, especialmente na América Latina (FABRICANTES DE MÁQUINAS..., 31/mai/07).

O setor de máquinas tem intensificado as estratégias de integração comercial, focando o contato com empresas estrangeiras que têm participado de feiras nacionais do setor ${ }^{49}$ : desde 2004, os projetos Comprador e Imagem, ambos desenvolvidos pela ABRAMEQ (com o apoio da Apex-Brasil) trazem visitantes de países com interesse nas máquinas brasileiras para calçados para participar da

\footnotetext{
${ }^{48}$ O selo By Brasil foi elaborado pela ABRAMEQ em parceria com ASSINTECAL, para representar os produtos brasileiros nas feiras internacionais do setor de calçados.

49 A ABRAMEQ elaborou o "Diretório de Máquinas", um catálogo publicado anualmente com informações sobre as empresas e os produtos desenvolvidos pela indústria brasileira de máquinas que contempla as 50 empresas associadas à instituição. O material é distribuído durante a realização da FIMEC e é encaminhado para compradores e clientes potenciais de outros países.
} 
FIMEC $^{50}$. Adicionalmente, algumas empresas brasileiras de máquinas para couro e calçados têm participado sistematicamente de feiras internacionais do setor, como é apresentado no quadro 8.

\begin{tabular}{|c|c|c|c|c|}
\hline \multirow{2}{*}{$\begin{array}{l}\text { Feiras internacionais de } \\
\text { máquinas para couro e } \\
\text { calçados (selecionadas) }\end{array}$} & \multicolumn{4}{|c|}{ Empresas brasileiras participantes das Feiras de máquinas } \\
\hline & 2004 & 2005 & 2006 & 2007 \\
\hline $\begin{array}{l}\text { IFLS } \\
\text { (International Footwear and } \\
\text { Leather Show) } \\
\text { Bogotá- Colômbia }\end{array}$ & n.d. & $\begin{array}{l}\text { Bremm Peck, } \\
\text { ERPS, Ivomaq, } \\
\text { Kehl, Master, } \\
\text { Carbim e Mecsul }\end{array}$ & $\begin{array}{l}\text { Master, Erps, Kehl, } \\
\text { Ivomaq, Mecsul, } \\
\text { Erretre e Bremm } \\
\text { Peck. Estas duas } \\
\text { últimas produzem } \\
\text { máquinas para o } \\
\text { setor couro, sendo } \\
\text { a primeira vez que } \\
\text { este segmento } \\
\text { participa de uma } \\
\text { feira na Colômbia } \\
\text { (FABRICANTES DE } \\
\text { MAQUINAS } \\
\text { BUSCAM...,26/Jan/ } \\
\text { 06). } \\
\end{array}$ & $\begin{array}{l}\text { BKS, Mecsul, } \\
\text { Michelon (espaço } \\
\text { Abrameq); ERPS, } \\
\text { Klein, Master } \\
\text { (Consórcio Mek } \\
\text { Brasil); Kehl, } \\
\text { Ivomaq, Sazi } \\
\text { (participação } \\
\text { independente) } \\
\text { (BRASIL } \\
\text { MOSTRA...,03/ag } \\
\text { o/07) }\end{array}$ \\
\hline $\begin{array}{l}\text { Anpic } \\
\text { (Asociación Nacional de } \\
\text { Provedores para la Indústria } \\
\text { del Calzado) } \\
\text { León e Guadalajara - } \\
\text { México }\end{array}$ & $\begin{array}{l}\text { BKS, Bremm } \\
\text { Peck, Copé, } \\
\text { ERPS, Guttler, } \\
\text { Himaco, Himapel, } \\
\text { Ivomaq, Kehl, } \\
\text { Klein, Master, } \\
\text { Mecsul, Michelon, } \\
\text { NBN, Poppi e Sazi } \\
\text { (US\$ 5 } \\
\text { MILHÕES..., } \\
\text { mar/04). } \\
\end{array}$ & $\begin{array}{l}\text { BKS, Bremm } \\
\text { Peck, ERPS, } \\
\text { Klein, Kehl, } \\
\text { Mecsul, Master, } \\
\text { NBN, Sulpol, } \\
\text { Morbach, } \\
\text { Michelon, ITI, } \\
\text { System Haus, } \\
\text { Sazi e } \\
\text { Tecnomaq }\end{array}$ & $\begin{array}{l}\text { Espaço da } \\
\text { Abrameq: BKS, } \\
\text { Mecsul, Kehl, NBN } \\
\text { e Cardall. Espaço } \\
\text { institucional: Erps } \\
\text { (FABRICANTES DE } \\
\text { MAQUINAS } \\
\text { BUSCAM...,26/Jan/ } \\
\text { 06). }\end{array}$ & $\begin{array}{l}\text { Bremm Peck, } \\
\text { ERPS, Kehl, } \\
\text { Klein, Mecsul, } \\
\text { Sulpol, } \\
\text { Systemhaus e } \\
\text { Universul (três } \\
\text { outras empresas } \\
\text { não divulgaram o } \\
\text { nome) }\end{array}$ \\
\hline $\begin{array}{l}\text { IILF } \\
\text { (India International Leather } \\
\text { Fair) } \\
\text { Chennai - Índia }\end{array}$ & n.d. & $\begin{array}{l}\text { Cardal e } \\
\text { Michelon }\end{array}$ & $\begin{array}{l}\text { Ivomaq e Master } \\
\text { (FABRICANTES DE } \\
\text { MAQUINAS } \\
\text { BUSCAM...,26/Jan/ } \\
\text { 06). } \\
\end{array}$ & n.d. \\
\hline $\begin{array}{l}\text { Tanning Tech } \\
\text { Bologna - Itália }\end{array}$ & $\begin{array}{l}\text { BKS, Bremm } \\
\text { Peck, Cardall, } \\
\text { Master, Michelon, } \\
\text { ITI e Sustemhaus }\end{array}$ & $\begin{array}{l}\text { BKS, Bremm } \\
\text { Peck e Master } \\
\text { (1) }\end{array}$ & n.d. & n.d. \\
\hline
\end{tabular}

\section{Quadro 8 - Participação de empresas nacionais de máquinas para calçados em feiras internacionais (selecionadas).}

\section{A ABRAMEQ tem coordenado estudos de mercado em países como a} Rússia, Ucrânia, Síria, Turquia, Índia, Marrocos, Tailândia e China ${ }^{51}$, visando à

\footnotetext{
${ }^{50}$ Em 2006, por exemplo, a feira recebeu a visita de potenciais compradores da Índia, México, Colômbia e Peru (ABRAMEQ TRARÁ VISITANTES..., 27/mar/06).

${ }^{51} \mathrm{O}$ objetivo do estudo é levantar informações sobre os seguintes aspectos: Demanda; Tipo e características das máquinas importadas e produzidas nestes países; Valor médio da compra e venda de máquinas nacionais e importadas; Estratégias de venda da concorrência; Financiamentos locais
} 
inserção das empresas brasileiras de máquinas para calçados nesses países. Como resultado, algumas empresas localizadas no SLP de Novo Hamburgo, por exemplo, têm exportado máquinas (de maneira bastante esporádica) para produtores de calçados da índia. Entretanto, um problema recorrente da prospecção é que nos países prospectados, freqüentemente, as empresas não querem tecnologia, mas preço, e neste ponto os fabricantes de máquinas de outros países podem apresentar mais vantagens que as empresas brasileiras (ABRAMEQ, 2005).

Um exemplo das estratégias de integração comercial do setor é o Programa Turn Key ${ }^{52}$, criado para ampliar a participação das empresas de máquinas nacionais de calçados nos países que não têm tradição no setor (como a África, o Oriente Médio e a América Central). O programa consiste na venda e instalação de fábricas completas de calçados, o que abrange desde os insumos até as tecnologias necessárias para a operacionalização de uma linha de fabricação de calçados ( $A$ UNIÃO..., out/05). A empresa de máquinas de costura Ivomaq, por exemplo, tem apostado na integração com empresas brasileiras de outros ramos do setor para o abastecimento do mercado externo (em especial a América Latina), por considerar que esse mecanismo pode reduzir significativamente os custos com o transporte e a instalação das máquinas nacionais (A UNIÃO..., out/05).

Cabe ressaltar que algumas empresas brasileiras de máquinas para couro e calçados também têm acentuado suas estratégias de comércio de máquinas no mercado interno, a partir da realização de consórcios de venda e compra de máquinas nos principais pólos brasileiros de calçados. De acordo com dados da ABRAMEQ de 2007, cerca de dez empresas nacionais de máquinas (BRSM, Erps, Kehl, Klein, Master, Mecsul, Morbach, Sulpol e Tecnomaq) participarão de feiras do setor de máquinas em 2007, com destaque para a Fenafic, realizada em Franca (FABRICANTES DE MÁQUINAS COMPRARÃO..., 31/mai/07).

Os programas voltados ao desempenho comercial do setor de máquinas têm refletido na ampliação da base de empresas brasileiras exportadoras de máquinas

oferecidos pela concorrência; Informações sobre aduanas, legislação e acordos comerciais; Listagem de agentes, distribuidores e representantes locais (CONSULTOR..., 19/jan/04).

52 O programa Turn Key começou a ser estruturado em 2003, a partir de um estudo conduzido pela ABRAMEQ, com o apoio de instituições como o Centro das Indústrias de Curtumes do Brasil (CICB), da Associação das Indústrias de Curtumes do Rio Grande do Sul (Aicsul) e da Associação Brasileira das empresas de Componentes para Couro, Calçados e Artefatos (Assintecal). Foi apresentado pela equipe da APEX em 2005, e está na fase de cadastramento junto a instituições de financiamento e câmaras de comércio internacionais (A UNIÃO..., out/05). 
(que era formada por 25 empresas em 1997, e passou para 38 empresas em 2005, como é apresentado na tabela 17 a seguir). Adicionalmente, o número de países que têm comercializado com o setor de máquinas nacional também aumento u de 15 países em 1997, para 24 países em 1998 (SETOR DE MÁQUINAS SUPERA..., set/99).

Tabela 17 - Número de empresas brasileiras exportadoras de máquinas para calçados

\begin{tabular}{lc}
\hline Ano & $\begin{array}{c}\text { Número de empresas exportadoras de } \\
\text { máquinas para calçados }\end{array}$ \\
\hline 1997 & 25 \\
1998 & 27 \\
1999 & 33 \\
2000 & 37 \\
2001 & n.d. \\
2002 & 42 \\
2003 & n.d. \\
2004 & 33 \\
2005 (1) & 38 \\
\hline Fonte: ABRAMEQ, disponível em AZEVEDO (2002); (1) ABRAMEQ (06/abr/07). \\
n.d.: não disponível.
\end{tabular}

Mas apesar dos esforços para a consolidação das máquinas brasileiras no mercado externo, nos últimos três anos as feiras internacionais de máquinas para o setor de calçados têm sinalizado uma participação expressiva de empresas chinesas. A FIMEC, por exemplo, que sempre apresentou a participação predominante de empresas da América Latina, teve o crescimento de 2,8\% (2005) para 6\% (2006) do número de visitantes chineses. Na Anpic, realizada em Leon, México, por sua vez, as máquinas asiáticas representaram cerca de $60 \%$ das máquinas em exposição na edição de 2006 (CONCORRÊNCIA CHINESA, 23/fev/06).

De maneira geral, a China tem integrado sua produção ao comércio intraindustrial na região da Ásia Oriental, que é o mercado mais importante para a China, e tem investido em economias de escala e na incorporação de tecnologias como forma de ampliar a sua pauta de exportações. Os resultados desses investimentos e esforços têm refletido no crescimento de sua participação nos mercados internacionais de vários segmentos de máquinas (MARRONE, 2006), como foi analisado no capítulo sobre a indústria de bens de capital.

No setor de máquinas para calçados, as empresas asiáticas apresentam equipamentos com diferencial de preços muito grande em relação às empresas 
brasileiras $^{53}$, trabalham com uma elevada escala de produção ${ }^{54}$ e têm um perfil mais agressivo de atuação no mercado externo (CHINESES..., 07/abr/06). Adicionalmente, algumas empresas de máquinas da China têm realizado parcerias com empresas italianas ${ }^{55}$ : partes da produção e da mecânica são realizadas na China e as partes com desenvolvimento tecnológico são da Itália (CONCORRÊNCIA CHINESA..., 23/fev/06), o que facilita a incorporação de componentes tecnológicos a preços mais acessíveis para os usuários do mercado internacional. Por conta desses fatores, os fabricantes chineses têm avançado em vários segmentos de máquinas para calçados do mercado brasileiro e entre os clientes da América Latina e México, em especial entre as máquinas em que os consumidores priorizam mais no preço que a qualidade das máquinas.

Entretanto, como as estruturas de especialização produtivas da China e do Brasil são relativamente distintas, alguns segmentos como o de máquinas destinadas ao setor de couro, podem apresentar oportunidades para as empresas brasileiras de máquinas (MARRONE, 2006). Nesse segmento, os dados de comércio internacional da China com o Brasil e com o mundo, para o período de 2003 a 2004, indicam um crescimento expressivo das importações chinesas de máquinas para couro do Brasil (de US\$ 19.925 para US\$ 128.434), enquanto as exportações chinesas para o Brasil caíram cerca de $80 \%$ (de US\$217.812 para 86.649), como pode ser verificado na tabela 18.

Tabela 18 - Exportação e importação chinesa de máquinas para couro

\begin{tabular}{|c|c|c|c|c|c|c|}
\hline \multirow{2}{*}{$\begin{array}{l}\text { Ano } \\
2003\end{array}$} & \multicolumn{2}{|c|}{$\begin{array}{l}\text { Exportações de máquinas } \\
\text { para couro da China } \\
\text { (em US\$ FOB) }\end{array}$} & \multirow{2}{*}{$\begin{array}{c}\begin{array}{c}\text { Crescimento } \\
\text { das } \\
\text { exportações } \\
(\%)\end{array} \\
-\end{array}$} & \multicolumn{2}{|c|}{$\begin{array}{l}\text { Importações de máquinas } \\
\text { para couro na China } \\
\text { (em US\$ FOB) }\end{array}$} & \multirow{2}{*}{$\begin{array}{c}\text { Crescimento } \\
\text { das } \\
\text { importações } \\
(\%)\end{array}$} \\
\hline & & 7.956 .980 & & & 86.304 .811 & \\
\hline 2004 & Para o mundo & 13.822 .486 & 73,7 & Do mundo & 93.126 .238 & 7,9 \\
\hline 2005 & & 25.153 .863 & 82,0 & & 95.367 .619 & 2,4 \\
\hline 2003 & & 217.812 & $-99,1$ & & 19.925 & $-100,0$ \\
\hline 2004 & Para o Brasil & 291.670 & 33,9 & Do Brasil & 19.894 & $-0,2$ \\
\hline 2005 & & 86.649 & $-70,3$ & & 128.734 & 547,1 \\
\hline
\end{tabular}

Fonte: Marrone, 2006, p. 131-132.

\footnotetext{
${ }^{53}$ Uma máquina similar pode ser vendida no Brasil por $R \$ 130$ mil e na China custa cerca de $R \$ 40$ mil (CHINESES..., 07/abr/06).

54 Uma fábrica chinesa pode produzir, no mínimo, mil máquinas por ano, exportando $70 \%$, principalmente para África do Sul, Oriente Médio e Índia (CHINESES..., 07/abr/06).

${ }^{55}$ Cabe ressaltar que a Itália é o país europeu que tem sofrido mais com a concorrência das exportações chinesas, de modo que as parcerias para a produção na China tem sido um mecanismo para baratear a produção italiana de máquinas para calçados.
} 
No final de 2005, a indústria chinesa de máquinas para couro apresentou déficit comercial de US\$ 42.085 mil com a indústria brasileira, o que pode indicar uma demanda potencial dos fabricantes chineses que poderia ser atendida por empresas brasileiras de máquinas. Entretanto, o baixo número de empresas nacionais de máquinas participantes de feiras internacionais do setor, em especial nos países asiáticos, ilustra que esse potencial para a entrada no segmento de couro tem sido pouco explorado pelo mercado nacional.

Cabe ressaltar que mesmo no segmento de máquinas para calçados, em que a concorrência tem se dado de maneira bem mais acirrada, principalmente entre os segmentos de máquinas mais commoditizadas, à medida que as empresas brasileiras intensificam as relações com outras etapas da cadeia de calçados, as oportunidades para a resolução de problemas e os mecanismos de aprendizado inovativo e incorporação de novos atributos tendem a reforçar a sua participação no comércio internacional porque as empresas concorrentes apresentam dificuldades de assistência técnica e não têm produtos com a mesma qualidade das máquinas fabricadas no mercado nacional. 


\section{Procedimentos metodológicos}

Esta dissertação de mestrado apresenta uma análise empírica do aprendizado interativo entre empresas de máquinas para calçados e seus usuários nos principais sistemas locais de produção (SLPs) de calçados - localizados na cidade de Franca (SP) e no Vale do Rio dos Sinos (RS) - considerando os efeitos dessas relações para a organização interna e desenvolvimento das empresas de máquinas e como forma de intensificar os conhecimentos e a inovação no interior dos SLPs

A pesquisa empírica foi realizada por meio de duas estratégias distintas e complementares. Em primeiro lugar, foram realizados o levantamento $e$ sistematização de informações obtidas em fontes secundárias setoriais, disponíveis em versão eletrônica e, principalmente, na consulta às bibliotecas e instituições de Novo Hamburgo. Em segundo lugar, foram aplicados questionários em nove empresas produtoras de máquinas e quatro empresas de calçados. No total de empresas de máquinas, sete têm suas unidades de produção localizadas na cidade de Novo Hamburgo, no Vale do Sinos, e duas empresas estão concentradas na cidade de Franca (SP). Além disso, foram entrevistados os representantes de quatro instituições de apoio ao setor e três pesquisadores que realizaram importantes estudos sobre a dinâmica da indústria de calçados ${ }^{56}$.

Um aspecto importante para o estudo empírico é que como os segmentos de máquinas para calçados têm pouca representatividade no total da indústria de bens de capital, a disponibilização de seus dados em fontes mais tradicionais de informação, como os jornais e estudos de ampla circulação nacional, é relativamente mais difícil. Por conta desses fatores, a análise empírica foi realizada, principalmente, a partir do acesso à fontes de informações em revistas setoriais; do portal de notícias Global21 (que lista informações setoriais recuperadas de várias fontes); e do portal de notícias disponíveis no sítio da ABRAMEQ e do IBTEC. No quadro 9 a seguir são listadas todas as fontes de informação usadas na definição da amostra, na caracterização das empresas e do setor de máquinas para calçados e

\footnotetext{
${ }^{56}$ Para informações sobre a lista com as empresas de máquinas e de calçados e com as instituições que colaboraram com a pesquisa, ver anexo 2 deste arquivo. Por razões de sigilo, não serão apresentadas informações individualizadas das empresas.
} 
na análise das relações usuário-produtor no interior dos SLPs:

\begin{tabular}{|l|c|}
\hline \multicolumn{1}{|c|}{ Fontes de consulta setoriais } & $\begin{array}{c}\text { Períodos de referência das } \\
\text { publicações/notícias consultadas }\end{array}$ \\
\hline Revista Tecnicouro & Março de 2004 a Junho de 2007. \\
\hline Revista Passarela & Março de 2005 a Agosto de 2006. \\
\hline Revista Lançamentos - Máquinas, Couros e Componentes & Abril de 2005 a Abril de 2007. \\
\hline Banco de notícias do sítio da ABRAMEQ & Maio de 2005 a Setembro de 2007. \\
\hline Banco de notícias do sítio do IBTEC & Maio de 2005 a Setembro de 2007. \\
\hline Banco de notícias do sítio da Couromoda & Maio de 2005 a Setembro de 2007. \\
\hline \multicolumn{1}{|c|}{ Outras fontes de consulta setoriais } & 2006 e 2007. \\
\hline Catálogo ABRAMEQ & 2000. \\
\hline Panorama Setorial Gazeta Mercantil & Maio de 2005 a Setembro de 2007. \\
\hline Portal Globa21 & Maio de 2005; Abril de 2006. \\
\hline $\begin{array}{l}\text { Catálogo de Exportadores Brasileiros da Confederação } \\
\text { Nacional das Indústrias (CNI) }\end{array}$ \\
\hline
\end{tabular}

Fonte: Elaboração própria.

Quadro 9 - Fontes de consulta setoriais utilizadas na pesquisa empírica.

Outra dificuldade da pesquisa foi a elaboração de uma amostra de empresas de máquinas do setor para a realização do estudo empírico. Os jornais e revistas de grande circulação e os estudos setoriais não apresentam dados sobre faturamento ou número de funcionários dos segmentos de bens de capital. Nesse sentido, tornou-se necessário a elaboração de outros critérios que ajudassem a delimitar uma amostra de empresas de máquinas e que possibilitasse uma caracterização adequada da dinâmica industrial e competitiva das empresas e dos segmentos de máquinas para calçados. No quadro 10 são apresentados os critérios de seleção da amostra de empresas de máquinas para calçados e as fontes de informação consultadas nesse processo e na caracterização do setor.

\begin{tabular}{|c|c|c|}
\hline $\begin{array}{l}\text { Critérios para a seleção de } \\
\text { empresas de máquinas para } \\
\text { calçados }\end{array}$ & $\begin{array}{l}\text { Situação da amostra de } \\
\text { empresas de máquinas }\end{array}$ & $\begin{array}{l}\text { Fontes consultadas para a } \\
\text { definição dos critérios de } \\
\text { seleção da amostra }\end{array}$ \\
\hline Associação à ABRAMEQ & Sim. & $\begin{array}{l}\text { - Catálogo ABRAMEQ } \\
2006 \text { e } 2007 \text {. }\end{array}$ \\
\hline $\begin{array}{l}\text { Vendas para o mercado } \\
\text { interno (período 2005-2007) }\end{array}$ & Não disponível. & $\begin{array}{ll}- & \text { Revista Tecnicouro; } \\
\text { - } & \text { Portal Globa21; } \\
& \text { Panorama Setorial } \\
& \text { Gazeta Mercantil; } \\
\text { - } & \text { Banco de notícias do } \\
& \text { sítio da ABRAMEQ. }\end{array}$ \\
\hline
\end{tabular}

Continua 
Continuação

\begin{tabular}{|c|c|c|}
\hline $\begin{array}{l}\text { Vendas para o mercado } \\
\text { externo (período 2005-2007) }\end{array}$ & $\begin{array}{l}\text { Sim. } \\
\text { As empresas participaram do } \\
\text { catálogo de exportadores } \\
\text { brasileiros (CNI), na faixa de } \\
\text { exportações de até US\$ } \\
1 \text { milhão, por NCM. }\end{array}$ & $\begin{array}{ll}- & \text { Catálogo CNI; } \\
\text { - } & \text { Revista Tecnicouro; } \\
\text { - } & \text { Portal Globa21; } \\
\text { - } & \text { Panorama Setorial } \\
& \text { Gazeta Mercantil; } \\
\text { - } & \text { Banco de notícias do } \\
& \text { sítio da ABRAMEQ. }\end{array}$ \\
\hline $\begin{array}{l}\text { Participação em feiras } \\
\text { nacionais do setor (período } \\
\text { 2005-2007) }\end{array}$ & $\begin{array}{l}\text { Sim. } \\
\text { As empresas têm participação } \\
\text { nas principais feiras regionais } \\
\text { do setor, como a FIMEC (São } \\
\text { Paulo) e Francal (Franca). }\end{array}$ & $\begin{array}{ll}- & \text { Revistas Setoriais } \\
\text { (Tecnicouro, Passarela } \\
\text { e Lançamentos); } \\
\text { Banco de notícias do } \\
\text { sítio da ABRAMEQ; } \\
\text { Banco de notícias do } \\
\text { sítio do IBTEC. } \\
\end{array}$ \\
\hline $\begin{array}{l}\text { Participação em feiras } \\
\text { internacionais do setor } \\
\text { (período 2005-2007) }\end{array}$ & $\begin{array}{l}\text { Sim. } \\
\text { As empresas participaram, } \\
\text { principalmente, das feiras da } \\
\text { América Latina e México. }\end{array}$ & $\begin{array}{ll}- & \text { Revistas Setoriais } \\
\text { (Tecnicouro, Passarela } \\
\text { e Lançamentos); } \\
\text { Banco de notícias do } \\
\text { sítio da ABRAMEQ; } \\
\text { Banco de notícias do } \\
\text { sítio do IBTEC. } \\
\end{array}$ \\
\hline $\begin{array}{l}\text { Integração das empresas com } \\
\text { instituições de ensino e de } \\
\text { apoio aos SLPs de calçados } \\
\text { (período 2005-2007) }\end{array}$ & $\begin{array}{l}\text { Sim, em especial com a } \\
\text { ABRAMEQ, IBTEC, SENAI e } \\
\text { escolas técnicas locais. }\end{array}$ & $\begin{array}{l}\text { - Revistas Setoriais } \\
\text { (Tecnicouro, Passarela } \\
\text { e Lançamentos). }\end{array}$ \\
\hline $\begin{array}{l}\text { Lançamento de produtos } \\
\text { (período 2005-2007) }\end{array}$ & Sim. & $\begin{array}{l}\text { - Revistas Setoriais } \\
\text { (Tecnicouro, Passarela } \\
\text { e Lançamentos). }\end{array}$ \\
\hline $\begin{array}{l}\text { Realização de interações } \\
\text { horizontais }\end{array}$ & Sim. & $\begin{array}{l}\text { - Revistas Setoriais } \\
\text { (Tecnicouro, Passarela } \\
\text { e Lançamentos). }\end{array}$ \\
\hline $\begin{array}{l}\text { Realização de interações } \\
\text { verticais }\end{array}$ & Sim. & 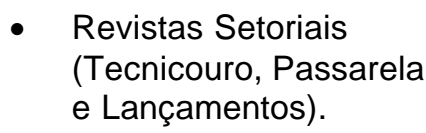 \\
\hline
\end{tabular}

Fonte: Elaboração própria, com base na pesquisa realizada em fontes secundárias.

Quadro 10 - Critérios de definição da amostra de empresas de máquinas para calçados

Para compreender a dinâmica produtiva e as características do aprendizado interativos sob o ponto de vista do usuário, foram selecionadas, aleatoriamente, duas empresas de calçados femininos com unidades de fabricação no Vale do Sinos (Via UNO e Calçados Chinesinha) e duas empresas de calçados masculinos localizadas na cidade de Franca (Ferraroni e Biaggio).

Cabe ressaltar que no ano de 2005, houve um contato inicial com as instituições de apoio ao setor de máquinas da cidade de Novo Hamburgo (RS) ABRAMEQ e IBTEC. Nesse período, foi realizada uma entrevista com a representante da ABRAMEQ visando a delimitação dos aspectos mais relevantes para compreender a dinâmica competitiva das empresas de máquinas e a 
caracterização das estratégias adotadas pela instituição. Adicionalmente, foram selecionados alguns estudos e reportagens disponíveis nas bibliotecas públicas do departamento de economia da Universidade Federal do Rio Grande do Sul (UFRGS) e da Universidade Vale do Sinos (UNISINOS), e no acervo bibliográfico do IBTEC.

A aplicação dos questionários e as visitas às unidades de produção das empresas do Vale do Sinos contaram com a colaboração da ABRAMEQ e da ABICALÇADOS, que tiveram papel fundamental para a pesquisa por intermediar o contato e agendamento das entrevistas nas empresas de máquinas e de calçados. As entrevistas realizadas em Franca, por sua vez, foram viabilizadas pela colaboração do IPT através do agendamento de entrevistas e das visitas às empresas de calçados de médio e pequeno porte.

\subsection{Questões analíticas e questionários aplicados na pesquisa empírica}

O questionário aplicado junto às empresas de máquinas e de calçados teve o propósito de captar as características dos tipos de relações, interações e acordos existentes entre as empresas de máquinas e os usuários da cadeia calçadista, considerando as eventuais limitações das relações usuário-produtor e os seus efeitos para a organização interna às empresas de máquinas e o desenvolvimento tecnológico do SLP de calçados.

As questões aplicadas nas empresas de máquinas e de calçados foram elaboradas a partir da organização de construtos definidos na revisão teórica dos capítulos 1 e 2 da dissertação, que são apresentados no quadro 11 a seguir.

\begin{tabular}{|c|c|}
\hline QUESTÃO ANALÍSTICA & CONSTRUTOS \\
\hline \multicolumn{2}{|c|}{ Características gerais das empresas de máquinas, quanto ao seu padrão tecnológico. } \\
\hline $\begin{array}{l}\text { Qual o perfil geral das empresas de máquinas e as } \\
\text { estratégias voltadas às melhorias no seu padrão } \\
\text { técnico. }\end{array}$ & $\begin{array}{l}\text { - } \frac{\text { Fatores determinantes das atividades }}{\text { inovativas: fontes, tipos de usuários e }} \\
\text { mecanismos de apropriação. } \\
\text { - } \quad \text { Trajetória tecnológica } \\
\text { Características mensuradas: fontes de } \\
\text { tecnologia, inovação relativamente } \\
\text { predominante; tamanho relativo das } \\
\text { empresas inovadoras; e intensidade e } \\
\text { direção da diversificação tecnológica. }\end{array}$ \\
\hline
\end{tabular}

Continua 
Continuação

\begin{tabular}{|c|c|}
\hline QUESTÃO ANALÍSTICA & CONSTRUTOS \\
\hline \multicolumn{2}{|c|}{ Característicos gerais das empresas de máquina, quanto ao regime tecnológico dos segmentos. } \\
\hline $\begin{array}{l}\text { Quais as propriedades da tecnologia criada e } \\
\text { incorporada nos segmentos. }\end{array}$ & $\begin{array}{l}\text { - } \text { Condições de oportunidade. } \\
\text { - Grau de cumulatividade. } \\
\text { - Condições de apropriação. }\end{array}$ \\
\hline \multicolumn{2}{|c|}{ Propriedades do conhecimento-base nas empresas de máquinas. } \\
\hline $\begin{array}{l}\text { Verificar se há possibilidades para alterar/melhorar (até } \\
\text { que ponto) as características do conhecimento-base nas } \\
\text { relações verticais. }\end{array}$ & - Propriedades do conhecimento-base. \\
\hline \multicolumn{2}{|c|}{ Características do aprendizado (interno e externo) às empresas } \\
\hline $\begin{array}{l}\text { Verificar as principais fontes de aprendizado (interno e } \\
\text { externo) utilizadas pelas empresas de máquinas para } \\
\text { couro e calçados. }\end{array}$ & $\begin{array}{l}\text { - } \quad \text { Aprendizado interno e/ou externo à } \\
\text { empresa } \\
\text { - Relações horizontais e/ou verticais - } \\
\text { situação atual, relevância para a empresa, } \\
\text { grau de riscos. }\end{array}$ \\
\hline $\begin{array}{l}\text { Verificar como aprendizado (interno e externo) das } \\
\text { relações sociais (horizontal e vertical) tem sido utilizado } \\
\text { por essas empresas. }\end{array}$ & $\begin{array}{l}\text { - Aprendizado interno: by-doing; by-using; } \\
\text { by-interacting. } \\
\text { - Aprendizado externo: by imitating; by- } \\
\text { cooperating; by-interacting. }\end{array}$ \\
\hline \multicolumn{2}{|c|}{ Modos de conversão do conhecimento em empresas de máquinas para calçados } \\
\hline $\begin{array}{l}\text { Caracterizar as etapas de incorporação, socialização e } \\
\text { modificação das informações externas e a } \\
\text { transformação em conhecimento interno. }\end{array}$ & $\begin{array}{l}\text { - } \quad \text { Aquisição externa de conhecimento. } \\
\text { - } \quad \text { Aquisição interna de conhecimento. } \\
\text { - } \quad \text { Combinação/Codificação. } \\
\text { - } \quad \text { Socialização. } \\
\text { - } \quad \text { Internalização. } \\
\text { - }\end{array}$ \\
\hline \multicolumn{2}{|c|}{ Conversão do conhecimento externo nas relações com usuários do SLP de calçados } \\
\hline $\begin{array}{l}\text { Verificar como as relações estabelecidas com usuários } \\
\text { têm interferido no conhecimento-base e na formação de } \\
\text { competências do SLP }\end{array}$ & 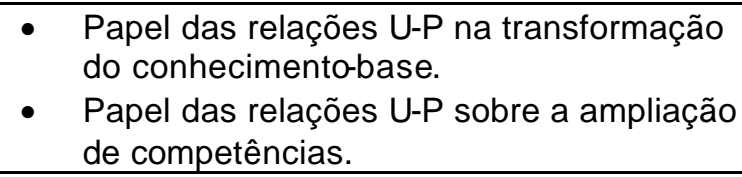 \\
\hline $\begin{array}{l}\text { Verificar em quais competências as relações com } \\
\text { usuários podem interferir. }\end{array}$ & $\begin{array}{l}\text { - } \quad \text { Competência tecnológica de produtos. } \\
\text { - } \quad \text { competências e as mudanças de } \\
\text { - } \quad \text { Capacidade de absorção. } \\
\end{array}$ \\
\hline \multicolumn{2}{|c|}{ Relações usuário-produtor: fatores que podem delimitar o aprendizado entre empresas em SLPs } \\
\hline $\begin{array}{l}\text { Verificar o que fortalece o aprendizado com os usuários } \\
\text { ou como as empresas lidam com os fatores que podem } \\
\text { dificultar esse aprendizado. }\end{array}$ & $\begin{array}{l}\text { - Dimensão social das relações: incerteza -> } \\
\text { códigos de comportamento e relações } \\
\text { fechadas e seletivas. } \\
\text { - Natureza da tecnologia envolvida: } \\
\text { estacionária, incremental, radical ou } \\
\text { revolução tecnológica. } \\
\text { - Características do ambiente interno às } \\
\text { empresas produtoras: formação } \\
\text { profissional; realimentação entre } \\
\text { departamento e intraempresas; e processo } \\
\text { de ruptura e incorporação de novos } \\
\text { elementos às rotinas. }\end{array}$ \\
\hline
\end{tabular}

Continua 
Continuação

\begin{tabular}{|c|c|}
\hline QUESTÃO ANALÍSTICA & CONSTRUTOS \\
\hline \multicolumn{2}{|c|}{ Fatores que podem limitar as competências dinâmicas das empresas de máquinas e de calçados } \\
\hline $\begin{array}{l}\text { Caracterizar as condições técnicas e organizacionais (e } \\
\text { quais as estratégias) das empresas voltados à criação } \\
\text { de competências. }\end{array}$ & $\begin{array}{l}\text { Processo administrativo e organizacional: } \\
\text { forma como coordenam a atividades; } \\
\text { capacidade de configurar e reconfigurar } \\
\text { habilidade organizacional. } \\
\text { - Posição quanto aos ativos mais difíceis de } \\
\text { transacionar: ativos tecnológicos, } \\
\text { complementares, financeiros e } \\
\text { locacionais. } \\
\text { Trajetória: alternativas disponíveis para as } \\
\text { empresas em termos de dependência da } \\
\text { trajetória. }\end{array}$ \\
\hline \multicolumn{2}{|c|}{$\begin{array}{l}\text { Fatores que interferem na capacidade de absorção de conhecimento nas empresas de máquinas e de } \\
\text { calçados }\end{array}$} \\
\hline $\begin{array}{l}\text { Verificar se a capacidade de absorção (futuro) pode ser } \\
\text { influenciada (atenuada ou intensificada) pelos seguintes } \\
\text { fatores: conhecimento-base; investimentos; e agentes } \\
\text { responsáveis pela transmissão das informações } \\
\text { externas para os departamentos da empresa. }\end{array}$ & $\begin{array}{l}\text { Dificuldades para manipular e mudar as } \\
\text { propriedades do conhecimento-base. } \\
\text { - } \quad \text { Nível de investimentos da empresa. } \\
\text { Estruturas de transferência do } \\
\text { conhecimento externo (presença ou não } \\
\text { de gatekeeper) e distância cognitiva entre } \\
\text { os atores (funcionários, gatekeeper). } \\
\text { - Grau de importância atribuída às relações } \\
\text { U-P para a capacidade de absorção de } \\
\text { novos conhecimentos (sem importância, } \\
\text { relevante, muito relevante). }\end{array}$ \\
\hline \multicolumn{2}{|c|}{$\begin{array}{l}\text { Características dos atores envolvidos no processo de inovação das empresas de máquinas e de } \\
\text { calçados }\end{array}$} \\
\hline $\begin{array}{l}\text { Verificar o papel das instituições de apoio, públicas e } \\
\text { privadas, para a organização das atividades inovativas } \\
\text { das empresas nos dois segmentos. }\end{array}$ & \\
\hline
\end{tabular}

Fonte: Elaboração própria.

Quadro 11 - Questões analíticas e construtos da pesquisa empírica.

Desse modo, as questões empíricas aplicadas nas empresas de máquinas para calçados estão organizadas em seis temas gerais ${ }^{57}$ :

1) Dinâmica tecnológica das empresas de máquinas para calçados;

2) Características das fontes de informação interna e externa às empresas;

3) Características conversão do conhecimento, inclusive das relações com usuários do setor de calçados;

4) Efeitos da conversão do conhecimento (a partir da interação com os usuários) para o desempenho das empresas de máquinas;

5) Fatores que podem interferir na capacidade de absorção do conhecimento entre empresas produtoras e usuárias de máquinas;

${ }^{57}$ O questionário aplicado nas empresas de máquinas para calçados de Franca e Novo Hamburgo é 
6) Características dos atores envolvidos no processo de aprendizado inovativo entre empresas usuárias e produtoras;

As questões aplicadas junto às empresas de calçados, por sua vez, foram organizadas em dois temas, visando caracterizar os contatos com fabricantes de máquinas e verificar em que medida eles têm ajudado no desenvolvimento das empresas usuárias. Os temas abordados nas empresas de calçados de Franca e Novo Hamburgo são ${ }^{58}$ :

1) Características das relações estabelecidas com produtores de máquinas para calçados;

2) Efeitos das relações estabelecidas com produtores de máquinas para calçados;

A pesquisa empírica também apresenta os resultados de entrevistas realizadas junto aos representantes de instituições de apoio e de ensino das cidades de Novo Hamburgo e São Leopoldo (RS), no Vale do Sinos, e da cidade de Franca, que são listadas a seguir:

- Associação Brasileira das Indústrias de Máquinas para Couro e Calçados (ABRAMEQ) - Novo Hamburgo (RS);

- Instituto Brasileiro de Tecnologia do Couro, Calçados e Artefatos (IBTEC) Novo Hamburgo (RS);

- Associação Brasileira das Indústrias de Calçados (ABICALÇADOS) - Novo Hamburgo (RS);

- Instituto de Pesquisas Tecnológicas (IPT) - unidade de Franca (SP);

- Universidade do Vale do Rio dos Sinos (UNISINOS) - São Leopoldo (RS).

Cabe ressaltar que o roteiro de questões aplicadas às instituições de apoio ao setor difere das questões aplicadas nas empresas por conta do seu papel na formação e revisão de competências. De maneira geral, as questões destinadas ao IBTEC e à Abrameq são abertas e estão voltadas basicamente à caracterização da dinâmica atual e da perspectiva de longo prazo em termos de fomento e apoio ao potencial de geração de melhorias, sob a ótica institucional ${ }^{59}$.

\footnotetext{
apresentado no anexo 4 desse documento.

${ }^{58} \mathrm{O}$ questionário aplicado nas empresas de calçados de Franca e Novo Hamburgo é apresentado no anexo 5 desse documento.

${ }^{59} \mathrm{O}$ roteiro de questões aplicado nas instituições de apoio ao setor pode ser consultado no anexo 6 .
} 


\section{A dinâmica industrial de empresas de máquinas para calçados}

O estudo empírico apresentado nesse capítulo reúne as características principais e a análise das informações coletadas junto a um grupo de nove empresas de máquinas para calçados nos dois principais SLPs de calçados, sendo que sete delas apresentam a sede administrativa e produção no município de Novo Hamburgo (RS), na região do Vale do Sinos (RS) e duas empresas de máquinas têm suas atividades concentradas na cidade de Franca (SP) ${ }^{60}$. A localização dos dois SLPs é apresentada, respectivamente, nas figuras 6 e 7.

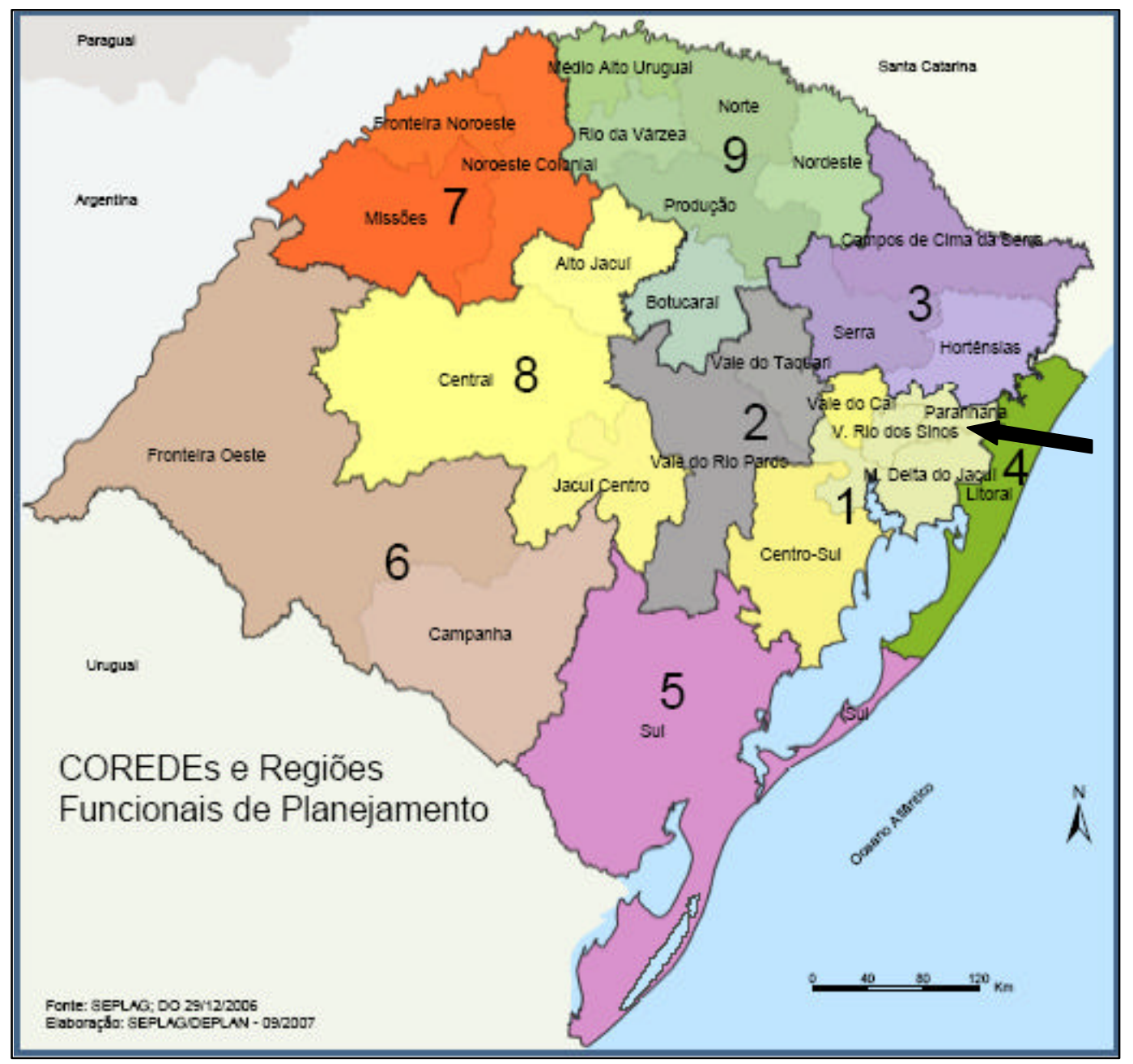

Fonte: Atlas Sócio-econômico do Rio Grande do Sul (2007).

COREDES: Conselhos Regionais de Desenvolvimento ${ }^{61}$.

Figura 6 - Localização da região do Vale do Rio do Sinos.

\footnotetext{
${ }^{60}$ As notas técnicas com informações sobre as empresas de máquinas para calçados podem ser consultadas no Anexo 3.

61 Os COREDES foram agregados em 9 regiões Funcionais, constituindo-se nas escalas de regionalização do Plano Plurianual 2008-2011 (Atlas Sócio Econômico do Rio Grande do Sul, 2007).
} 


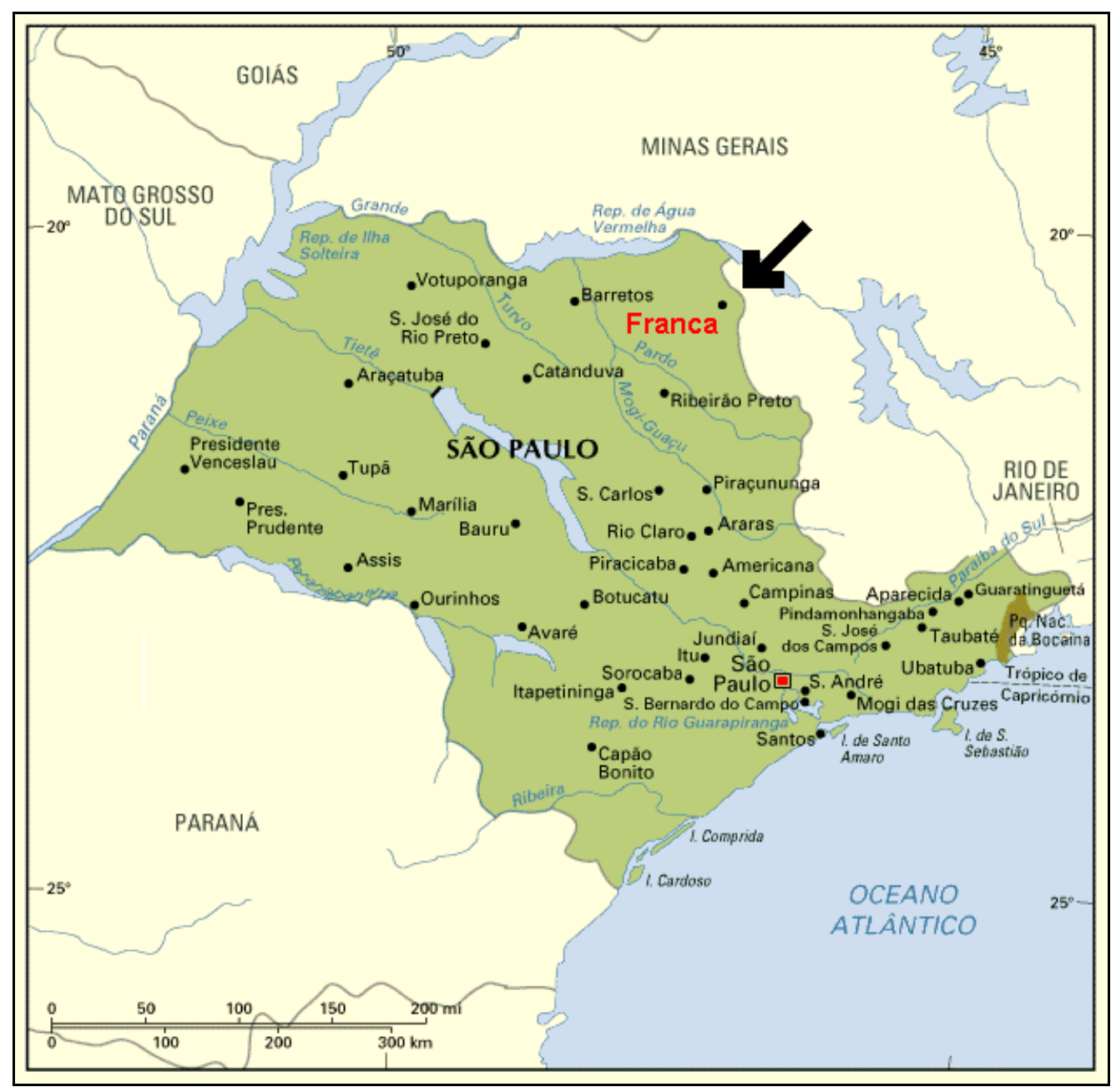

Fonte: Sítio da prefeitura municipal de Franca. Acesso em 23 de outubro de 2007.

Figura 7 - Localização da cidade de Franca

A amostra é formada por empresas nacionais, de peque no e médio porte, e que iniciaram suas atividades no período entre as décadas de 50 e 70 , localizandose junto aos principais pólos de produção de calçados por conta das facilidades decorrentes da proximidade geográfica com os segmentos fornecedores de ins umos e para atender ao aumento da demanda de máquinas nas duas regiões.

A atividade produtiva das empresas está voltada para os segmentos de calçados e de couro, mas algumas empresas também fabricam máquinas para outros setores como a indústria têxtil; de móveis; e de brinquedos e utilidades domésticas (quadro 12). 


\begin{tabular}{|c|c|c|c|}
\hline Amostra & $\begin{array}{l}\text { Segmento de } \\
\text { atuação }\end{array}$ & Localização & Produtos \\
\hline $\begin{array}{l}\text { Poppi Máquinas e } \\
\text { Equipamentos } \\
\text { Ltda }\end{array}$ & $\begin{array}{c}\text { Calçados e artefatos } \\
\text { de couro. }\end{array}$ & $\begin{array}{c}\text { Franca } \\
(\mathrm{SP})\end{array}$ & $\begin{array}{l}\text { Máquinas para calçados: prensa hidráulica } \\
\text { para corte; máquinas de pré-moldar e } \\
\text { conformar contrafortes; montar base de } \\
\text { calçados; forno conformador de alta pressão; } \\
\text { câmara automática de vaporização de } \\
\text { cabedais; montar lateral de calçados com cola; } \\
\text { transportadora de produção. }\end{array}$ \\
\hline $\begin{array}{l}\text { Ivomaq Indústria } \\
\text { e Comércio de } \\
\text { Máquinas Ltda }\end{array}$ & $\begin{array}{c}\text { Calçados e artefatos } \\
\text { de couro. }\end{array}$ & $\begin{array}{l}\text { Franca } \\
(\mathrm{SP})\end{array}$ & $\begin{array}{l}\text { Máquina para couro e calçados: costura } \\
\text { industrial para calçados, bolsas, cintos e } \\
\text { artefatos de couro; máquinas de costurar } \\
\text { solados (blaqueadeira) para plantas e laterais; } \\
\text { parte de peças de máquinas de costura } \\
\text { industrial. }\end{array}$ \\
\hline Himaco & $\begin{array}{l}\text { Calçados, } \\
\text { Brinquedos, } \\
\text { Utensílios } \\
\text { domésticos }\end{array}$ & $\begin{array}{l}\text { Novo } \\
\text { Hamburgo } \\
\text { (RS) }\end{array}$ & $\begin{array}{l}\text { - Máquinas para calçados: injetoras para } \\
\text { termoplástico. }\end{array}$ \\
\hline $\begin{array}{l}\text { Indústria de } \\
\text { Máquinas ERPS } \\
\text { Ltda }\end{array}$ & $\begin{array}{c}\text { Calçados e artefatos } \\
\text { de couro }\end{array}$ & $\begin{array}{l}\text { Novo } \\
\text { Hamburgo } \\
(\mathrm{RS})\end{array}$ & $\begin{array}{l}\text { - Máquinas para a montagem de calçados: } \\
\text { dublar; aplicar couraça; montar bico; montar } \\
\text { lado; carimbar/numerar. }\end{array}$ \\
\hline $\begin{array}{l}\text { Máquinas Kehl } \\
\text { Ltda }\end{array}$ & $\begin{array}{c}\text { Calçados e artefatos } \\
\text { de couro; móveis }\end{array}$ & $\begin{array}{l}\text { Novo } \\
\text { Hamburgo } \\
\text { (RS) }\end{array}$ & $\begin{array}{l}\text { Máquinas para calçados: virar cortes e virar } \\
\text { tiras, aplicar cola, debruar palmilhas, aplicar } \\
\text { ilhoses, aplicar fita de reforço, aplicar adesivos } \\
\text { látex; Máquina para couro: corte automático } \\
\text { computadorizado }\end{array}$ \\
\hline $\begin{array}{l}\text { Máquinas Klein } \\
\text { S/A Indústria e } \\
\text { Comércio }\end{array}$ & Calçados e couro & $\begin{array}{l}\text { Novo } \\
\text { Hamburgo } \\
\text { (RS) }\end{array}$ & $\begin{array}{l}\text { - Máquinas para calçados: dividir e chanfrar } \\
\text { contrafortes (automáticas). } \\
\text { - Máquinas para couro: balancim hidráulico de } \\
\text { corte, balancim ponte. }\end{array}$ \\
\hline $\begin{array}{c}\text { Master } \\
\text { Equipamentos } \\
\text { Industriais Ltda }\end{array}$ & Calçados e couro & $\begin{array}{l}\text { Novo } \\
\text { Hamburgo } \\
\text { (RS) }\end{array}$ & $\begin{array}{l}\text { - Máquinas para calçados: conformar } \\
\text { contrafortes; secador reativador; prensa } \\
\text { pneumática para solas; máquina de tirar rugas. } \\
\text { - Máquinas para couro: forno conformador e } \\
\text { conformador a frio; medidora de rolos; } \\
\text { acabamento para couros inteiros; expansão } \\
\text { contínua. }\end{array}$ \\
\hline $\begin{array}{c}\text { Mecsul Máquinas } \\
\text { e Equipamentos } \\
\text { Ltda }\end{array}$ & $\begin{array}{c}\text { Calçados e artefatos } \\
\text { de couro }\end{array}$ & $\begin{array}{l}\text { Novo } \\
\text { Hamburgo } \\
\text { (RS) }\end{array}$ & $\begin{array}{l}\text { - Máquinas para calçados: tirar rugas, pregar } \\
\text { saltos, conformar contrafortes; secador e } \\
\text { reativador; prensa para solas; estufa } \\
\text { reativadora; estabilizadora térmica. }\end{array}$ \\
\hline Zambelli \& Cunha & $\begin{array}{c}\text { Calçados e artefatos } \\
\text { de couro }\end{array}$ & $\begin{array}{c}\text { Novo } \\
\text { Hamburgo } \\
\text { (RS) }\end{array}$ & $\begin{array}{l}\text { - Máquinas para calçados: lixar e polir; fresar e } \\
\text { asperar; corte (chanfrar, cortar, dividir, entalhar, } \\
\text { perfurar palmilha, etc). }\end{array}$ \\
\hline
\end{tabular}


Quanto ao perfil de suas atividades produtivas, as empresas fabricam várias linhas de máquinas dentro de uma mesma família de produtos, com o objetivo de ampliar as opções por níveis tecnológicos e preços para o atendimento das empresas de calçados de pequeno e médio porte com necessidades distintas. $O$ principal motivo para a diversificação das linhas de produtos é que o setor apresenta uma dinâmica de incorporação e adaptação de melhorias (mesmo que incrementais) que, freqüentemente, resultam em novos produtos.

As máquinas podem ser produzidas em série ou sob encomenda, apresentando pequenas variações tecnológicas entre as linhas. A produção sob encomenda é mais comum nos segmentos de máquinas para corte e montagem, que fabricam produtos mais customizados, demandam tecnologias mais complexas e de custo elevado. Mas mesmo nesses segmentos, as empresas apresentam produtos semi-prontos desenvolvidos a partir da programação com base na demanda do período anterior.

A heterogeneidade de produtos e níveis tecnológicos nas empresas de máquinas dificulta a caracterização do nível de produção anual (em volumes) e do nível de utilização da capacidade produtiva. Em todos os segmentos, as empresas fabricam máquinas com base técnica que pode ser mecânica ou microeletrônica, com diferentes patamares de desenvolvimento de tecnologias e que, por esse motivo, refletem nos preços e nos volumes de cada produto demandado. Como o valor agregado atribuído em cada modelo de máquina pode variar significativamente, o volume de produção total não é um critério adequado para avaliar o desempenho da empresa.

A amostra de empresas de máquinas destina grande parte de suas vendas para o mercado interno (85\% da produção total), enquanto o restante das vendas (15\%) é destinado ao mercado externo. A pauta de exportação tem a participação sistemática dos mercados da América Latina (Argentina, Venezuela, Chile, Peru e Colômbia) e o México. Adicionalmente, algumas empresas brasileiras têm participação mais esporádica no comércio exterior com Espanha, Inglaterra, Índia e China. Por outro lado, se considerarmos o desempenho por segmentos, as empresas de máquinas para injetados plásticos e máquinas de costura têm enfrentado maior concorrência com produtos provenientes da Ásia, e por esse motivo, já registraram algumas perdas das vendas realizadas em países da América Latina. 
As empresas de máquinas organizam suas atividades fabris em uma única unidade de produção e contam com a participação de representantes comerciais nos outros estados com fabricação de calçados e no mercado externo.

Os gatekeepers responsáveis pela incorporação de informações externas e a sua difusão no ambiente interno à empresa de máquina são os funcionários da representação comercial, assistência técnica e os gerentes de produção.

As equipes de representação comercial e, principalmente, de assistência técnica são formadas por funcionários com conhecimentos técnicos e experiência acumulada sobre o funcionamento das máquinas, sendo os principais canais de acesso às informações externas aos SLPs: enquanto os representantes de vendas têm conhecimentos sobre os processos e as máquinas comercializadas e, por esse motivo, apresentam as condições necessárias para identificar as novidades do ambiente externo à empresa; a assistência técnica tem um contato direto com os usuários durante a produção, e por esse motivo, podem propor modificações no uso das máquinas ou solucionar alguma dificuldade técnica.

Adicionalmente, a assistência técnica identifica as necessidades de revisão do projeto das máquinas, representando o elo entre o usuário da empresa de calçados e o departamento de produção da empresa de máquina. O engenheiro da máquina, por sua vez, traduz as informações das fontes externas e, a partir de reuniões com os técnicos das máquinas e com os funcionários do projeto e de eletrônica, decidem a viabilidade financeira da modificação incremental e da comercialização dos novos produtos.

Um aspecto interessante é que as empresas de máquinas de Novo Hamburgo e de Franca não têm contratos de exclusividade com seus representantes: normalmente, um mesmo técnico representa várias empresas de máquinas no mercado interno e externo, o que é explicado pela complementaridade da tecnologia das máquinas e na resolução de problemas técnicos e pela necessidade de reduzir os custos com o atendimento em outros mercados. Entretanto, esse fator não é visto como impeditivo para o desempenho das empresas de máquina nesses mercados.

De maneira geral, as empresas de máquinas para couro e calçados têm algumas etapas das atividades produtivas realizadas fora da unidade, principalmente a fundição, usinagem e chaparia. A justificativa para a externalização da produção é que como o volume de produtos demandados é muito pequeno, para a maioria das empresas não compensa produzir internamente. 
Nesse sentido, algumas empresas destacam que a externalização é realizada a partir de canais de comunicação estabelecidos com ex-funcionários que se tornam prestadores de serviço, facilitando o desenvolvimento de acordos de compra e venda (de curto prazo) e o atendimento dos produtores de máquinas. Entretanto, algumas empresas de máquinas destacaram que têm intenção de internalizarem essas etapas do processo produtivas porque acreditam que têm escala para isso e que podem reduzir a dependência de fornecedores e garantir maior qualidade das peças.

Os principais atributos competitivos das empresas de máquinas para calçados são as condições de atendimento às necessidades dos usuários: as empresas apresentam flexibilidade para modificar ou agregar tecnologias e componentes aos seus modelos de máquinas. Adicionalmente, a aglomeração espacial e proximidade cultural entre os produtores e usuários das máquinas facilitam a comunicação entre os segmentos a jusante e a montante, acelerando a troca de informações sobre dificuldades técnicas ou a realização de eventuais melhorias em produtos ${ }^{62}$.

Por outro lado, as empresas de máquinas apresentam baixo capital de giro, principalmente as pequenas empresas, o que inviabiliza os investimentos na expansão da sua capacidade produtiva. Além disso, em muitos casos os gastos com as modificações nos projetos originais das máquinas não são diluídos na produção de calçados - por conta da variação no tamanho dos lotes e da elevada variabilidade dos modelos de calçados - então o produtor de máquinas não pode cobrar o preço de mercado por seus produtos.

Por fim, as empresas de máquinas para calçados também podem ser caracterizadas por seu desenvolvimento atrelado às flutuações das taxas de investimento (seja em ampliação e ou na modernização da capacidade produtiva dos usuários), que refletem diretamente em sua dinâmica tecnológica e de incorporação de melhoria como será analisado nas próximas páginas.

\footnotetext{
${ }^{62}$ Apesar do suporte e das garantias oferecidas pelos produtores de máquinas, freqüentemente, os calçadistas fazem comparações entre os valores das máquinas ofertadas e o tipo de produto que ela procura (MODELAGEM..., mar-abr/05).
} 


\subsection{O regime tecnológico do setor de máquinas para calçados}

O regime tecnológico é caracterizado a partir das propriedades da tecnologia interna às empresas: conhecimento-base; condições de cumulatividade; grau e mecanismos de apropriação do conhecimento e as condições de oportunidade. No caso das empresas de máquinas para calçados, o regime tecnológico é apresentado no quadro 13.

\begin{tabular}{|c|c|c|c|c|}
\hline \multicolumn{5}{|c|}{ Regime tecnológico em empresas de máquinas para calçados } \\
\hline $\begin{array}{c}\text { Característica da } \\
\text { tecnologia }\end{array}$ & $\begin{array}{c}\text { Conhecimento- } \\
\text { base }\end{array}$ & $\begin{array}{c}\text { Grau de } \\
\text { oportunidade }\end{array}$ & $\begin{array}{c}\text { Nível de } \\
\text { Cumulatividade }\end{array}$ & $\begin{array}{c}\text { Grau de } \\
\text { apropriação }\end{array}$ \\
\hline Incremental & $\begin{array}{c}\text { Especializado e } \\
\text { divisível }\end{array}$ & Elevado & Elevado & Baixo \\
\hline \multicolumn{4}{|c|}{ Fonte: Elaboração própria, com base nas informações da pesquisa de campo. } \\
\hline
\end{tabular}

Quadro 13 - Características do regime tecnológico em empresas de máquinas para calçados.

De maneira geral, o conhecimento-base interno as empresas de máquinas para calçados é especializado, sendo coordenado pelo gerente de produção e a equipe de assistência técnica que atuam junto aos usuários levantando as sugestões e possibilidades para novo produtos e processos.

A especialização do conhecimento-base é explicada pela própria estrutura industrial do setor: como as empresas de máquinas apresentam estruturas relativamente pequenas e com baixo capital de giro, os funcionários tendem a ser multifuncionais e a partir de interações diárias entre os departamentos, podem intensificar os conhecimentos com outras áreas da empresa. Além disso, as empresas de máquinas apresentam baixa rotatividade do emprego, e isso facilita a especialização dos funcionários.

Entretanto, as empresas apresentam diferenças quanto à divisibilidade das informações técnicas entre os departamentos: em alguns casos, o conhecimentobase é não divisível, por conta do receio dos técnicos das máquinas em trocar informações com outras áreas que não contribuem para o desenvolvimento ou melhoria dos produtos; enquanto em outros casos (maioria), o envolvimento dos funcionários em várias atividades é o fator que permite a troca de informações entre os departamentos. 
A especialização e divisibilidade do conhecimento nas empresas de máquinas possibilitam a criação de novos produtos e a realização de mudanças incrementais, refletindo na alta cumulatividade das informações tecnológicas ao longo do tempo. O nível de cumulatividade das informações e capacitações internas dessas empresas define a trajetória que elas seguirão no atendimento da demanda de seus usuários, podendo facilitar a criação ou tornar inviável o desenvolvimento de produtos.

De maneira geral, as mudanças incrementais mais simples, por exemplo, podem demandar pouco tempo, dependendo das características técnicas do produto (materiais e tecnologias envolvidas na mudança) e das necessidades e do prazo estipulado pelo cliente sendo que, muitas vezes, um desses fatores pode tornar a criação inviável. As situações em que há mudanças no projeto original da máquina e a realização de testes do protótipo e reajustes no ato da produção podem estender o período entre o desenvolvimento e o lançamento do produto. Já os casos mais complexos, em que as empresas de máquina incorporam tecnologias estrangeiras ou utilizam uma base técnica pouco conhecida, por exemplo, podem precisar de projetos mais estruturados, com duração de até um ano para ser concluída.

Cabe ressaltar que as empresas de máquinas, de maneira geral, fabricam linhas de máquinas de base mecânica que são relançadas periodicamente com alguns diferenciais tecnológicos, como os modelos com tecnologia pneumática ou componentes microeletrônicos mais avançados. Nesse sentido, embora as empresas desenvolvam capacitações distintas de acordo com as interações com fontes internas e externas de aprendizado, o grau de apropriação do setor de máquinas para calçados é baixo.

Para compreender esse aspecto, é necessário considerar que a proximidade geográfica entre empresas de todos os segmentos do SLP de calçados facilita a interação e a troca de informações, principalmente de mercado, e o acesso a algumas melhorias desenvolvidas por outras empresas. Por esse motivo, ocasionalmente, as empresas especializadas numa mesma família de máquinas podem apresentar novos produtos com especificações e características muito similares aquelas apresentadas por seus concorrentes.

As empresas de máquinas utilizam o sistema de patente em suas linhas de produtos, mas esse mecanismo é pouco eficaz para proteger o acesso às informações de suas máquinas. Isso pode ser explicado por dois fatores: em 
primeiro lugar, a velocidade da mudança das melhorias incrementais em produtos é muito alta e quando a patente é obtida, o produto já apresenta outras alterações ${ }^{63}$; em segundo lugar, pode-se destacar que a elevada difusão de informações no interior dos sistemas locais de produção e a demora do processo de patentes também refletem na baixa eficácia do uso de patentes. Desse modo torna-se difícil limitar o acesso a uma informação de produto ou processo ao SLP e, quando a patente é obtida, o concorrente pode derrubar o processo porque qualquer alteração do produto precisaria de nova patente para proteger o conhecimento ${ }^{64}$.

A evolução da tecnologia incorporada às máquinas é outro instrumento de proteção de informações relativamente mais eficaz para as empresas de máquinas nacionais, principalmente entre aquelas que utilizam a base microeletrônica. Nas empresas de máquinas para as etapas de montagem, por exemplo, como os produtos são mais customizados, as melhorias através das interações com usuários podem intensificar essa evolução da tecnologia, dificultando a cópia de outras empresas. Adicionalmente, a utilização desse recurso apresenta um nível de dificuldade moderado, porque as empresas dependem das condições do mercado para investir em melhorias.

A defasagem temporal é o outro instrumento de proteção das informações utilizado por empresas de máquinas para couro e calçado. Mas diferentemente da evolução tecnológica, a defasagem temporal tem eficácia irregular e apresenta mais dificuldades para a proteção dos conhecimentos. A principal justificativa é que como as informações no interior dos SLPs são bastante difundidas e a tecnologia tem característica estacionária, torna-se difícil para uma empresa desenvolver novos atributos com maior regularidade ao longo do tempo.

As condições de oportunidade do setor de máquinas para criar melhorias em produtos dependem da sua capacidade para ampliar habilidades e resolver problemas a partir do contato com as fontes internas e externas de informação: quanto mais a empresa acumula essas capacitações, maiores serão as oportunidades para inovar.

\footnotetext{
${ }^{63}$ As peculiaridades entre os mercados de calçados femininos e masculinos, por exemplo, interferem na utilização de patentes porque como as máquinas estão sempre mudando para se adaptar às variações dos modelos, torna-se inviável investir na proteção das informações técnicas.

64 Mesmo com as dificuldades para proteger as informações dos concorrentes, as empresas de máquinas têm apostado na patente de produtos com componentes eletrônicos ou na patente de processos incorporados à máquinas como forma de inibir a cópia de seus produtos
} 
A organização das empresas de máquinas em sistemas locais mais dinâmicos (nas cidades de Novo Hamburgo e Franca) tem contribuído para fortalecer as condições de oportunidade do setor, porque nesses sistemas locais, a produção e conhecimento estão mais integrados e contam com fontes de aprendizado externas às empresas e internas aos SLPs ${ }^{65}$ para desenvolver inovações. Nesse sentido, as empresas do Vale do Sinos tendem a apresentar a base organizacional para a aquisição e criação de informações mais aberta, enquanto a base organizacional para a difusão dessas informações tende a ser mais ativa e cooperativa.

As interações estabelecidas entre as empresas de máquinas e os demais segmentos e instituições do setor de calçados (assim como os contatos realizados com outros setores industriais) têm aumentado o nível de oportunidade para inovações de processo e de produto do setor de máquinas para calçados, em especial nos segmentos de máquinas que desenvolvem produtos mais customizados e estão mais expostos à sazonalidade da demanda. Entretanto, as empresas de máquinas do SLP de Novo Hamburgo têm apresentado mais interações com empresas do SLP, enquanto as empresas de máquinas do SLP de Franca, por sua vez, não têm a mesma facilidade de interação porque a característica geral desse SLP é a de segmentos mais fechados à relações ao longo da cadeia.

Nesse sentido, as elevadas condições de oportunidade das empresas de máquinas são explicadas pelo acesso a fontes de aprendizado externas às empresas, como as interações verticais estabelecidas com os usuários da cadeia de calçados, analisadas nas seções seguintes.

\subsection{As características das fontes de aprendizado}

A maneira como as informações são incorporadas ao sistema de produção das empresas de máquinas para couro e calçadas é relevante para o regime

\footnotetext{
${ }^{65}$ Os sistemas locais menos dinâmicos apresentam mais obstáculos para aumentar o nível de oportunidade das empresas de máquinas, porque esses sistemas não têm uma estrutura densa com todas as etapas da cadeia de calçados e porque as interações estabelecidas com fontes externas as empresas também são menos consistentes.
} 
tecnológico do setor de máquinas, na medida em que reflete na sua capacidade para gerar e difundir melhorias em produtos ao longo do tempo.

As fontes de aprendizado de tecnologias utilizadas por todos os segmentos de máquinas podem ser internas às empresas (por meio de relações interdepartamentos), externas às empresas (a partir de interações de caráter horizontal e vertical) e externas aos SLPs. Em todas essas situações, os caminhos escolhidos para criar, acumular e difundir informações determina a direção da mudança técnica e as vantagens competitivas do setor no mercado interno e externo.

No quadro 14 a seguir, são apresentados alguns critérios com base no estudo de Figueiredo (2001), que ajudam a compreender a dinâmica de incorporação e difusão de inovações do setor de máquinas par calçados.

\begin{tabular}{|l|l|c|c|c|}
\hline $\begin{array}{c}\text { Processos de } \\
\text { aprendizagem }\end{array}$ & $\begin{array}{c}\text { Tipo da intera ção } \\
\text { (formal ou } \\
\text { informal) }\end{array}$ & $\begin{array}{c}\text { Funcionamento } \\
\text { (Ruim-Moderado- } \\
\text { Bom) }\end{array}$ & $\begin{array}{c}\text { Intensidade } \\
\text { (Baixa- } \\
\text { Intermitente- } \\
\text { Contínua) }\end{array}$ & $\begin{array}{c}\text { Freqüência } \\
\text { (Baixa-moderada- } \\
\text { elevada) }\end{array}$ \\
\hline $\begin{array}{l}\text { Aquisição interna } \\
\text { de conhecimento }\end{array}$ & & & \\
\hline $\begin{array}{l}\text { Aquisição externa } \\
\text { de conhecimento }\end{array}$ & & & \\
\hline \multicolumn{2}{|l|}{ Fonte: Figueiredo (2001). }
\end{tabular}

Quadro 14 - Parâmetros utilizados na caracterização dos processos de aprendizagem em empresas de máquinas para calçados.

As interações são classificadas como formais ou informais; enquanto o processo de aprendizado interno e externo, por sua vez, apresenta diferenças em termos de níveis funcionamento, de intensidade e da freqüência com que ocorre entre as empresas usuárias e produtoras de máquinas:

- Níveis de funcionamento - indicam se a empresa de máquina consegue (ou não) absorver e transformar as informações em melhorias produtos.

- Níveis de intensidade - indicam a freqüência com que as empresas aprendem na produção.

- Níveis de freqüência - indicam em que medida as empresas recorrem à esse mecanismo.

As empresas de máquinas para couro e calçados realizam o aprendizado 
interno, principalmente, a partir das atividades de engenharia e das reuniões interdepartamentos.

O aprendizado a partir da produção (learning-by-doing) nas empresas de máquinas pode ser caracterizado por apresentar bom funcionamento porque à medida que as informações são incorporadas internamente pela assistência técnica ou pelo representante comercial, os gerentes de produção traduzem as informações em conhecimentos técnicos para o desenvolvimento ou as melhorias dos produtos.

O aprendizado interno ocorre principalmente nas etapas de incorporação de componentes eletrônicos e de teste final da máquina (seja com o operador da linha de montagem ou com o usuário), quando os funcionários verificam as especificações e níveis de produtividade da máquina e, eventualmente, podem consultar o projeto original da máquina. Nesses casos, o conhecimento acumulado sobre o processo de produção, as irregularidades na fabricação dos sapatos e as características mecânicas e técnicas das máquinas oferecidas no mercado nacional são utilizados para buscar novas oportunidades técnicas e de produtos.

Adicionalmente, a intensidade do aprendizado durante a produção é relativamente distinta de uma empresa para outra - intensidade intermediária ou contínua - visto que depende de como as informações externas são traduzidas em reuniões interdepartamentos, principalmente entre as áreas de vendas, a assistência técnica - que codifica as sugestões e problemas dos consumidores e o que pode ser melhorado na máquina - e o gerente da produção - que discute e testa as sugestões com os funcionários da modelagem e a diretoria (administração, custos).

As reuniões interdepartamentos são realizadas de maneira freqüente porque as empresas não têm grupos de funcionários com atividades voltadas exclusivamente para pesquisas e modificações de produtos $^{66}$ : as percepções de produto e de mercados dos gatekeepers são responsáveis pelo atendimento e a antecipação às exigências dos usuários de máquinas.

De maneira geral, os gatekeepers e a equipe da diretoria das empresas máquinas para calçados realizam reuniões com mais freqüência que as equipes das empresas de máquinas para curtume. A principal justificativa é que as melhorias solicitadas por empresas de calçados, em especial nos calçados femininos que têm

\footnotetext{
${ }^{66}$ Apenas uma empresa ressaltou que tem funcionários do departamento de engenharia envolvidos exclusivamente no desenvolvimento - atividades de protótipo-projeto e com experiência em mecânica.
} 
maior variação de modelos, são relativamente mais comuns do que as mudanças levantadas por usuários de máquina para curtumes.

O desenvolvimento de capacitações a partir da experiência acumulada ao longo dos anos, especialmente entre as empresas de pequeno porte, é facilitado pela baixa rotatividade do emprego nas áreas mais envolvidas com o aprendizado interdepartamentos, uma vez que os funcionários têm uma visão mais abrangente do processo de produção e das características mecânicas dos produtos.

Vale ressaltar que as reuniões interdepartamentos têm uma característica informal: praticamente não há reuniões formais com a direção da empresa porque, muitas vezes, as modificações podem ser resolvidas sem esse recurso - as sugestões são tão simples que dispensam a participação da diretoria. Além disso, a realização de reuniões formais é determinada, de fato, pelo acúmulo de informações provenientes da assistência técnica e pela necessidade de alterar a programação relacionada às atividades produtivas da empresa.

Entretanto, œmo o fluxo de informações internas às empresas de máquina não requer reuniões formais entre os departamentos (financeiro, diretoria, produção, assistência técnica), freqüentemente, os caminhos escolhidos pelas equipes podem ser diferentes em termos de produtividade e custos de fabricação do novo modelo de máquina ${ }^{67}$.

Nesse cenário, os fabricantes de máquinas dos dois SLPs têm apresentado estratégias em comum para amenizar as diferenças interdepartamentos e reduzir a margem de erros na modificação das características das máquinas. De maneira geral, as empresas realizam a revisão de projetos, dos materiais e dos produtos, testando a máquina durante a fabricação antes de encaminhar o projeto para a linha de montagem. O departamento responsável pela incorporação de componentes eletrônicos, por exemplo, têm suas atividades integradas com a etapa de design e melhoria dos novos modelos, com o objetivo de testar as soluções em mecânica ou em componentes mais avançados. Até mesmo as peças da etapa de usinagem, fabricadas freqüentemente fora das empresas, em alguns casos, são testadas antes de seguir para a produção.

\footnotetext{
${ }^{67}$ Em alguns casos, os técnicos oferecem resistência às transformações de sistemas complexos em tecnologias mais simples para o usuário e que reduzem o valor agregado da máquina, mesmo sabendo que o nível tecnológico elevado do modelo original é oneroso e desnecessário para o consumidor.
} 
Em alguns casos em que os custos de produção para realizar alguma modificação são muito altos para a empresa de máquina, os contatos com fornecedores de outros segmentos têm ajudado a otimizar a produção internamente e garantir a oferta desses produtos com melhorias por um preço mais acessível ao consumidor. Entretanto, as empresas de máquinas não conseguem sustentar boas margens de lucro, preferindo arcar com preços próximos aos custos de produção para não perder o contato com o usuário no longo prazo. Já nas empresas de pequeno porte, a estrutura de negócios e as especificações técnicas das máquinas podem dificultar a realização das modificações sugeridas pelos usuários.

A dinâmica de aprendizado interno às empresas de máquinas para couro e calçados é apresentada no quadro 15 abaixo:

\begin{tabular}{|c|c|c|c|c|c|}
\hline \multicolumn{7}{|c|}{ Características do aprendizado interno } \\
\hline $\begin{array}{c}\text { Tipo de } \\
\text { interação }\end{array}$ & Funcionamento & Intensidade & Freqüência & Dificuldade & $\begin{array}{c}\text { Mecanismos } \\
\text { para resolver as } \\
\text { dificuldades }\end{array}$ \\
\hline Informal (3) & Bom & $\begin{array}{c}\text { Intermediária } \\
\text { ou Contínua } \\
(1)\end{array}$ & Elevada (2) & $\begin{array}{c}\text { Soluções } \\
\text { inadequadas; } \\
\text { Custos } \\
\text { financeiros; }\end{array}$ & $\begin{array}{c}\text { Revisão dos } \\
\text { projetos; } \\
\text { Contatos com } \\
\text { fontes externas. }\end{array}$ \\
\hline $\begin{array}{l}\text { Fonte: Elaboração própria, com base nas informações da pesquisa de campo. } \\
\text { (1) Depende do funcionamento das reuniões interdepartamentos; (2) Para o aprendizado de reuniões } \\
\text { interdepartamentos; (3) Para o aprendizado de reuniões interdepartamentos. }\end{array}$ \\
\hline
\end{tabular}

Quadro 15 - Características do aprendizado interno às empresas de máquinas para calçados.

Vale ressaltar que conhecimentos acumulados internamente - na fase de produção ou a partir de reuniões interdepartamentos - dependem, em grande medida, dos contatos estabelecidos com outras fontes de informação externas às empresas e ao SLP.

O aprendizado de fontes externas às empresas de máquinas pode ocorrer, de duas maneiras: a partir das interações com usuários do setor de calçados nacional (principalmente dos SLPs de Franca e Novo Hamburgo) e, em menor grau, através das relações com empresas de calçados de países da América Latina. Entretanto, as relações estabelecidas com os fornecedores de insumos e componentes eletrônicos (especialmente dos SLPs e de outros setores); as relações estabelecidas entre as empresas de máquinas e seus concorrentes do mercado interno e externo, assim como os acordos realizados com instituições de apoio, 
também podem contribuir para o aprendizado de novas oportunidades e nichos de mercado.

De maneira geral, o aprendizado a partir das fontes de informação com usuários e fornecedores das empresas de máquinas apresenta um bom funcionamento, porque as empresas contam com a proximidade geográfica e identidade cultural que facilitam o estabelecimento de canais de comunicação e a troca de informações entre os segmentos da cadeia de calçados. Adicionalmente, os conhecimentos obtidos através de interações com usuários são relativamente mais intensos (contínuos) que o aprendizado a partir do contato com fornecedores: as modificações em insumos e componentes não repercutem em alterações no desenvolvimento de produtos, salvo os casos em que as empresas de máquinas incorporam componentes eletrônicos mais avançados.

Em primeiro lugar, as interações estabelecidas com os usuários do setor de calçados têm repercutido no aprendizado de mudanças incrementais, porque os gatekeepers coletam informações sobre possibilidades para fazer melhorias e as empresas ajustam as suas linhas, criando versões diferentes das máquinas para faixas de renda e necessidades distintas do mercado interno.

Nas relações com usuários do mercado externo, as empresas brasileiras de máquinas também desenvolvem capacidades para apresentar produtos com as especificações requeridas pelos clientes. Porém, como as empresas não contam com proximidade geográfica, o principal aspecto da interação é a participação do técnico da empresa brasileira na apresentação da máquina e no treinamento dos funcionários da empresa usuária.

Cabe ressaltar que as interações estabelecidas entre os fabricantes de máquinas e os usuários também podem apresentar algumas diferenças de acordo com o segmento de atuação das empresas - máquinas para curtumes ou para calçados: as empresas de máquinas para curtumes não apresentam representantes de vendas com conhecimentos técnicos, apenas o departamento comercial, fato esse explicado pela baixa demanda por assistência técnica e porque como o segmento tem baixa concorrência, então não é necessária a visita com alta freqüência. No segmento de máquinas para calçados, por sua vez, os representantes têm papel fundamental para a criação de competências porque traduzem as diferenças locais na utilização das máquinas e na concepção dos calçados das empresas visitadas. 
Um aspecto importante para essas interações é que as empresas de máquinas com atuação na América Latina, freqüentemente, não apresentam representantes exclusivos para a assistência técnica de seus produtos fora do país, mas funcionários contratos por empresas do setor de máquinas nacional. $E$ isso pode fragilizar a relação entre essas empresas e os usuários e dificultar a pesquisa de novas oportunidades de mercado ${ }^{68}$.

As relações com empresas fornecedoras de insumos, principalmente componentes eletrônicos e automação - WEG, Romi, Newton, Siemens, Bosch entre outras - podem contribuir para o desempenho das empresas, em especial aquelas que fabricam produtos customizados e com componentes microeletrônicos.

De maneira geral, as empresas de máquinas de Franca e Novo Hamburgo desenvolvem alguns canais de comunicação com fornecedores localizados nos SLPs e com outros setores industriais ou outros Estados, embora a proximidade geográfica entre as empresas facilite mais o contato com os agentes da mesma aglomeração espacial.

Nesse sentido, os contatos com fornecedores podem ser classificados por seu funcionamento moderado, porque permitem o acesso a novas tecnologias e a organização da produção, mas nem sempre visam às mudanças na capacitação interna porque são relações comerciais. Já a intensidade do aprendizado a partir dos contatos com fornecedores é baixa ou intermediária, uma vez que as parcerias desse tipo são bastante esporádicas ${ }^{69}$. Entretanto, alguns contatos estabelecidos com os fornecedores de insumos e componentes têm muito mais impacto sobre o desenvolvimento de competências de processo do que as relações com empresas de calçados: em alguns casos, as empresas de máquinas e de insumos são mais parceiras na busca de uma melhoria tecnológica, enquanto com a empresa de calçados, o produtor de máquinas tem sua atuação mais restrita à resolução de um problema específico ou à mudança na posição de algumas peças.

Outra modalidade de parceria estabelecida com fornecedores é o sistema de contratação de serviços de empresas de pequeno porte (em geral, formado por exfuncionários), visando exclusividade no fornecimento de peças e componentes e a manutenção de qualidade e preços mais viáveis para a produção de máquinas. Nas

\footnotetext{
${ }^{68}$ As características das relações usuário-produtor nos SLPs de calçados de Novo Hamburgo e Franca são discutidas na seção seguinte.

${ }^{69}$ Algumas empresas destacam que há desestímulo para desenvolver produtos em parcerias com
} 
empresas de médio porte, por sua vez, o aprendizado com fornecedores de insumos é realizado a partir do treinamento dos funcionários (engenharia ou assistência técnica) das empresas de máquinas, que incorporam as informações técnicas na unidade fornecedora e depois transferem os dados para os projetistas e demais funcionários da empresa de máquinas.

As empresas brasileiras de máquinas também têm realizado parcerias tecnológicas e comerciais com empresas de máquinas de outros países, principalmente a Itália e Alemanha. Entretanto, o número total de acordos é relativamente bem menor que as relações estabelecidas na década passada, apesar de as empresas (brasileiras) considerarem que os riscos dessas interações são baixos ou aceitáveis. A empresa de máquinas Mecsul, por exemplo, é um dos poucos exemplos de cooperação tecnológica com empresas estrangeiras: a Mecsul tem uma joint venture com a empresa italiana Sabal desde 1998, visando à melhoria tecnológica de seus produtos (GAZETA MERCATIL, 2000).

$\mathrm{Na}$ última década, a trajetória da tecnologia do setor de máquinas para calçados tem sido influenciada, em grande medida, pela participação dos usuários da indústria de calçados, que contribuem para a especialização dos conhecimentos internos às empresas de máquinas à medida que detectam possibilidades para resolver problemas técnicos ou melhorar a fabricação de calçados.

Nas empresas de máquinas para montagem de calçados femininos, por exemplo, o contato com os concorrentes deixou de ser o principal meio para a realização de mudanças nas máquinas brasileiras por conta de dois fatores: grande parte dos fabricantes nacionais tem as condições técnicas para realizar as melhorias no interior dos SLPs; e a representação comercial de máquinas estrangeiras no mercado interno (requerida em troca da cooperação tecnológica) dá margem à entrada de concorrentes, em especial os fabricantes de máquinas da China que têm atuado como fornecedores de empresas italianas ${ }^{70}$. Nesse sentido, o aprendizado a partir das parcerias com concorrentes do mercado externo tende a apresentar freqüência esporádica e funcionamento moderado.

Vale ressaltar que como os sistemas locais do Vale do Sinos e de Franca são

empresas de segmentos a jusante.

70 Uma empresa de máquinas do SLP de Novo Hamburgo destacou que foi representante nacional das máquinas de um concorrente italiano até o final dos anos 90. Atualmente a empresa estrangeira estabeleceu uma unidade de produção no mesmo SLP para a fabricação de máquinas chinesas e se tornou a principal concorrente da empresa brasileira de máquinas. 
bastante abertos às fontes externas de informação, os acordos tecnológicos e comerciais podem ajudar não apenas na inserção em outros mercados, mas permitem a atualização tecnológica gradual das máquinas brasileiras. Por esse motivo, o aprendizado a partir dessas fontes externas pode ser caracterizado por intensidade baixa.

\section{As relações horizontais estabelecidas com concorrentes do mercado}

interno, principalmente entre os agentes da mesma aglomeração espacial em que as empresas de máquinas estão localizadas, também podem ajudar no desenvolvimento das empresas de máquinas. Entretanto, essas relações têm o funcionamento moderado porque são limitadas à acordos comerciais para participação em novos mercados.

O aprendizado a partir dessas relações é baixo (ou nulo), ocorrendo de maneira esporádica e informal, mesmo entre as empresas que fabricam famílias de máquinas distintas. O Consórcio Mek by Brasil, por exemplo, tem o propósito de reforçar a presença das empresas brasileiras em países que apresentam uma participação expressiva no comércio internacional do setor, dificultando a entrada de empresas de máquinas concorrentes, mas pode agregar pouco ao aprendizado de novos mercados ${ }^{71}$.

As características gerais das fontes de aprendizado externo a partir do contato com usuários, fornecedores e concorrentes das empresas de máquinas podem ser resumidas no quadro 16.

\begin{tabular}{|l|c|c|c|c|}
\hline \multicolumn{5}{|c|}{ Características do aprendizado externo } \\
\hline $\begin{array}{c}\text { Fontes de aprendizado } \\
\text { externo às empresas }\end{array}$ & $\begin{array}{c}\text { Tipo de } \\
\text { interação }\end{array}$ & Funcionamento & Intensidade & Freqüência \\
\hline Usuários & Informal & Bom & Contínua & Elevada \\
\hline Fornecedores & $\begin{array}{c}\text { Formal/ } \\
\text { Informal }\end{array}$ & Bom & $\begin{array}{c}\text { Baixa/ } \\
\text { Intermediária }\end{array}$ & Esporádica \\
\hline $\begin{array}{l}\text { Concorrentes do mercado } \\
\text { interno }\end{array}$ & Informal & Moderado (1) & Baixa & Esporádica \\
\hline $\begin{array}{l}\text { Concorrentes do mercado } \\
\text { externo }\end{array}$ & Formal & Moderado (1) & Baixa & Esporádica \\
\hline $\begin{array}{l}\text { Fonte: Elaboração própria, com base nas informações da pesquisa de campo. } \\
\text { (1) Restrito à acordos para comercialização em outros mercados. }\end{array}$ \\
\hline
\end{tabular}

Quadro 16 - Características do aprendizado a partir de fontes externas às empresas de máquinas para calçados.

É necessário destacar que as empresas de máquinas para couro e calçados

\footnotetext{
${ }^{71}$ O Mek By Brasil é formado pelas empresas de máquinas Master, ERPS e Klein e intermediado pela ABRAMEQ para a compra e venda de máquinas para calçados no mercado colombiano (INDÚSTRIA BRASILEIRA..., 13/jul/07).
} 
também têm mantido contatos com institutos de pesquisa e de apoio ao setor de máquinas, como a ABRAMEQ, para a promoção tecnológica e comercial; o IBTEC, para a utilização de laboratórios; O SENAI e escolas técnicas, para cursos de formação profissional; e o IPT de Franca, que atua na análise de material, entre outros.

A ABRAMEQ, por exemplo, tem orientado as estratégias de inserção comercial das empresas de máquinas para calçados no mercado externo por meio do Programa Setorial Integrado, com o apoio da APEX: desde 1998, a entidade tem coordenado a participação em feiras internacionais do setor e realizou estudos de prospecção tecnológica para a entrada das empresas brasileiras de máquinas em outros mercados. No mercado interno, a entidade tem realizado eventos para a representação das máquinas e a troca de informações entre os usuários de outras regiões produtoras de calçados.

O IBTec reúne quase todos os segmentos da cadeia, mas o seu foco de atuação é técnico-tecnológico. Nos últimos sete anos, a entidade tem organizado dois eventos relevantes para a exposição de tecnologias e o desenvolvimento das empresas de máquinas: a Fábrica Modelo é realizada durante a Couromoda e reúne fornecedores de componentes e serviços (software CAD-CAM, por exemplo), visando à exposição dos avanços em máquina para o setor de calçados; o Projeto Passo a Passo, por sua vez, apresenta todas as etapas de fabricação de calçados e faz uma rotação dos temas apresentados a cada ano (calçados infantis, masculinos, femininos e bolsas) para mostrar as tecnologias, geralmente, as máquinas mais novas do mercado. Em cada exposição, as empresas levam vários modelos de máquinas - no último projeto, foram oito modelos distintos de máquinas utilizadas na fabricação de calçados infantis.

Ambas as instituições - ABRAMEQ e IBTec - têm contribuído para a difusão de informações sobre produtos entre os SLPs, através da coordenação de eventos visando a maior interação das empresas nacionais de máquinas com seus usuários do mercado interno. Além disso, as entidades de apoio ao setor criaram programas de promoção comercial como forma de atenuar os efeitos da participação de fabricantes asiáticos (principalmente as empresas chinesas) sobre as vendas das empresas brasileiras de máquinas para calçados. Não por acaso, as principais estratégias adotadas por empresas de máquinas dos SLPs de Franca e de Novo Hamburgo nos últimos anos são a abertura e consolidação de canais de comércio 
com usuários do mercado interno e externo. Entretanto, é necessário destacar que apesar dos inúmeros esforços das empresas de máquinas e entidades, a inserção das empresas nacionais em países prospectados tem apresentado dificuldades de ordem econômica - mesmo entre as empresas de médio porte, a participação em feiras de países como a Índia (que é o terceiro produtor mundial de calçados) demanda custos muito elevados com logística e reflete em poucos contatos comerciais.

Os institutos de pesquisa e as escolas técnicas localizadas nos dois sistemas locais de produção de calçados têm contribuído para o aprendizado tecnológico de processos e a atualização profissional dos funcionários das empresas de máquinas, a partir de cursos e palestras técnicas sobre tendências e novas possibilidades para o setor de calçados. Contudo, a participação das empresas de máquinas nesses programas e a realização de melhorias são limitadas, freqüentemente, por variações na demanda que inibem as expectativas e os investimentos das empresas de máquinas no longo prazo e pela ausência de capital de giro nas empresas de pequeno porte.

Nesse sentido, é importante diferenciar e reforçar a dupla contribuição das interações estabelecidas entre as empresas de máquinas e os usuários da indústria nacional de calçados:

- A inserção comercial amplia as vendas e pode repercutir nas condições para o aprendizado;

- O aprendizado interativo ajuda m desenvolvimento industrial das empresas detentoras de tecnologias e pode facilitar a sua participação em novos mercados.

A próxima seção analisa as relações entre empresas usuárias e produtoras de máquinas, com o propósito de compreender a segunda afirmação.

\subsection{As relações com os usuários da indústria de calçados}

As interações entre as empresas de máquina e seus usuários do setor de calçados têm refletido no desenvolvimento de novos produtos e em melhorias de processo nos interior dos SLPs de calçados porque interferem, diretamente, na 
integração entre os subsistemas de produção e de conhecimento no interior das aglomerações espaciais de empresas.

A integração entre os dois subsistemas pode ser explicada por dois fatores: em primeiro lugar, a presença de etapas tecnologicamente separáveis acentua a necessidade de compartilhamento de dados entre as empresas produtoras de máquinas e os fabricantes de calçados. Em segundo lugar, a proximidade geográfica e a identidade cultural entre empresas dos dois segmentos fortalecem o comprometimento entre os agentes com atividades distintas e complementares ra busca de melhorias para o processo de fabricação de calçados. Nesse sentido, as empresas de máquinas estabelecem fluxos de informação que facilitam o aprendizado entre as empresas de etapas distintas da cadeia de calçados.

Adicionalmente, integração entre os subsistemas é explicada pela característica aberta das interações entre os fabricantes de máquinas e empresas de calçados: usuários comparam os produtos fornecidos por mais de uma empresa, preferencialmente, entre aquelas localizadas na mesma aglomeração espacial; e paralelamente, os produtores investem em canais de comunicação com os usuários, através da assistência técnica e da participação em feiras e eventos do setor realizados localmente, em outros Estados ou no mercado externo.

O ponto central da discussão sobre as interações usuário-produtor nos SLPs de Novo Hamburgo e Franca é que elas interferem no regime tecnológico do setor de máquinas, uma vez que o acesso as fontes externas as empresas tem ajudado a criar e melhorar tecnologias de produtos e tem acentuado o aprendizado de caráter incremental. Como resultado, as empresas têm ampliado as condições de oportunidade para inovações e, paralelamente, elevam o nível de cumulatividade dos conhecimentos internos - seja em capacidades técnicas de produtos ou nas capacidades para aprender mais.

O fluxo de informações entre as empresas de máquinas e de calçados tem uma característica bastante tácita porque os agentes das aglomerações espaciais apresentam contatos informais com elevado nível de confiança entre os funcionários das empresas de ambos os segmentos. Os departamentos das empresas de máquinas mais envolvidos no aprendizado são a engenharia de produção e assistência técnica, que interagem junto aos gerentes de produção das empresas de calçados através da assistência técnica e da venda de máquinas.

O usuário tem participação direta nas fases iniciais de especificação e de 
projeto, nas quais ele apresenta os problemas técnicos ou sugestões de melhoria para a produção dos calçados ${ }^{72}$. De maneira geral, os principais atributos buscados pelos fabricantes de calçados são redução de custos, melhor qualidade e assistência técnica das máquinas. Entretanto, grande parte das empresas de máquinas para a montagem de calçados tem sua competitividade determinada mais pela flexibilidade de atendimento (capacidade de adaptar os produtos) e qualidade/produtividade do produto final. Nesses segmentos, o custo também interfere na demanda da máquina, mas como as empresas de máquinas desenvolvem vários modelos com funções similares e níveis distintos aplicação tecnológica, o custo pesa menos na decisão do usuário dessas máquinas.

O pedido de produção da máquina é encaminhado, inicialmente, apenas com as especificações das peças de usinagem que ficam armazenadas até o momento de começar a produção. Após a fase de especificação, o projeto é mostrado para a engenharia de produção, onde os funcionários (inclusive da área de eletrônica, se for preciso) decidem se é viável ou não produzir ou modificar o equipamento com as sugestões do operador (calçados). Já na fase em que a máquina está quase pronta, a empresa realiza o teste da parte mecânica, com o objetivo de identificar eventuais falhas, e incorpora os componentes eletrônicos ao produto ${ }^{73}$.

Nesse sentido, o aprendizado a partir do contato com os usuários pode ocorrer em dois momentos: na fase de projeto, por meio da ajuda no desenvolvimento e melhorias; e na fase de teste, quando o usuário passa as dificuldades no manuseio das máquinas.

Os contatos entre fornecedores e usuários das máquinas são mantidos, principalmente, por meio de mecanismos informais como visitas, telefones e reuniões irregulares com as empresas usuárias e por relações formais de pósvenda, em que a equipe de assistência técnica oferece suporte técnico para o atendimento pós-venda, cuida da manutenção das máquinas e realiza mudanças incrementais e a revisão dos projetos.

\footnotetext{
${ }^{72}$ O protótipo da máquina é desenvolvido com as características que o cliente pediu (falam apenas o problema), utilizando o programa Solid Work que é um software utilizado por quase todas as empresas de máquinas, para o cálculo das dimensões da máquina e das peças necessárias para executar o projeto.

${ }^{73}$ A área de instalação de componentes eletrônicos da maioria das empresas de máquinas está instalada no centro da unidade produtiva ou junto ao departamento de desenvolvimento, com o objetivo de trabalhar com os diferentes modelos de máquinas à medida que os pedidos chegam. Entretanto, algumas empresas estão com esse processo mais acelerado enquanto outras estão em
} 
As interações informais ocorrem na medida em que a empresa de calçados decide modernizar alguma etapa da fabricação ou expandir sua capacidade produtiva, em que o usuário busca informações como desempenho e tecnologias disponíveis nos modelos de máquinas do mercado interno. Mas como os fabricantes de calçados trabalham com elevada variabilidade de modelos e com sazonalidade da demanda, a interação informal é buscada, principalmente, para a reforma de um equipamento usado ou a aquisição de uma máquina (nova) com características tecnológicas de ampla aplicação: para adquirir uma máquina muito moderna e específica para um tipo de calçado, a empresa usuária precisa ter uma previsão de demanda muito alta de seus produtos para diluir os custos com a aquisição do equipamento.

Por outro lado, deve-se ressaltar que parte das melhorias em componentes eletrônicos incorporados às máquinas não foi puxada pela demanda (calçados), mas é o resultado de acordos estabelecidos com fabricantes de componentes de etapas a jusante - empresas localizadas no interior dos SLPs de calçados ou de outros setores industriais.

Já as interações de caráter formal têm apresentado dificuldades financeiras, em especial, entre as empresas de calçados de pequeno porte localizadas no SLP de Franca. De maneira geral, essas empresas recorrem apenas eventualmente aos produtores de máquinas porque os custos cobrados por serviços de assistência técnica das máquinas são economicamente inviáveis. Por esse motivo, as empresas com produção de calçados preferem 'testar' soluções por conta própria, antes de solicitar os serviços das empresas de máquinas.

Adicionalmente, as empresas de máquinas também têm enfrentado dificuldades na negociação de produtos e na realização de melhorias incrementais que podem resultar em relações mais fechadas e seletivas no interior dos SLPs.

No ambiente interno às empresas de máquinas, alguns projetos apresentam custos elevados que inviabilizam o atendimento de necessidades muito específicas, repercutindo inclusive na impossibilidade de produzir a máquina solicitada pelo usuário. De outro lado, resultam em margens de ganhos menores, mas que várias empresas incorporam para manter o mercado cativo. Além disso, algumas empresas de máquinas têm certa resistência em aceitar pedidos que requeiram a exclusão de 
tecnologias mais avançadas (componentes mecânicos em lugar de componentes microeletrônicos): duas empresas nacionais com atuação na América Latina destacam que é comum tirar a tecnologia para reduzir os custos, o que esbarra na qualificação técnica dos funcionários para tecnologias mais simples. Como a operação é mais simples, em alguns casos as empresas nacionais apresentam os produtos primeiramente na América Latina e depois no mercado interno

No ambiente externo aos fabricantes de máquinas, a demanda de pequenos lotes (principalmente nas empresas com produção de calçados femininos), a substituição e incorporação de novos materiais e a variação constante da moda e nas empresas de calçados restringem os investimentos na aquisição ou melhoria das máquinas em grande parte das empresas usuárias, principalmente nos segmentos de máquinas mais customizadas ${ }^{74}$.

Outro aspecto relevante é que a maioria das máquinas produzidas sob encomenda é adquirida como demonstração pelo usuário, através de acordos informais freqüentes e, nesses acordos, as empresas de máquinas têm apresentado alguns casos de devolução das máquinas logo após o término do prazo de demonstração ou após a produção da linha de calçados. Por esse motivo, a maioria das empresas fabricantes de máquinas tem reduzido o prazo para teste do produto de sessenta dias para até quinze dias, como forma de impedir ou dificultar os prejuízos com comportamentos oportunistas entre algumas empresas com produção de calçados, mas em muitos casos, não é possível rever os prazos de demonstração dos produtos sob pena de perder a venda das máquinas.

As flutuações macroeconômicas também interferem nas interações, com alguns efeitos, principalmente, na área comercial. No segmento de calçados, as flutuações cambiais repercutem em variações nas vendas e em modificações na demanda de máquinas para couro e calçados do mercado nacional. Já no segmento de máquinas, a instabilidade cíclica da demanda por máquinas em períodos de recessão ou prosperidade econômica reflete em alterações na realização de investimentos, seja em atualização ou na ampliação da capacidade produtiva do setor de máquinas dos dois SLPs. Todos esses aspectos do ambiente interno e

\footnotetext{
74 Algumas empresas de máquinas destacaram que os custos com tecnologias utilizadas na produção de lotes pequenos de sandálias - as quais variam de uma estação para outra - não são facilmente diluídos pelo preço de revenda desses produtos, então o produtor do calçado pode não aceitar pagar o preço da tecnologia incorporada na máquina.
} 
externo às empresas de máquinas têm refletido em aumento do nível de incertezas nas relações entre usuários e produtores, o que pode contribuir para interações mais fechadas e seletivas ao longo da cadeia de calçados.

Mas embora esses dois aspectos determinem variações significativas na oferta e demanda e na realização de investimentos em máquinas para couro e calçados, as empresas de máquinas não deixam de interagir (e aprender) com usuários. Ao contrário, os contatos com produtores de calçados são um dos instrumentos mais utilizados para sustentar as participações no mercado interno (e externo).

Nos SLPs de produção de calçados de Novo Hamburgo e de Franca, as empresas de máquinas incorporam novos atributos e acentuam a flexibilidade para trabalhar com máquinas customizadas ou commoditizados, contribuindo para o desenvolvimento das tecnologias utilizadas no setor de calçados. Os resultados dessas interações em termos de tecnologias de produto e de processo, assim como as características principais do aprendizado tecnológico em alguns segmentos de máquinas são analisados na próxima seção.

\subsection{Características do aprendizado inovativo nas relações usuário-produtor}

O aprendizado inovativo a partir das relações entre fabricantes de máquinas e seus usuários do setor de calçados tem apresentado significativas contribuições para o nível tecnológico dos produtos e as tecnologias de processo desenvolvidas no setor de máquinas para calçados.

O desenvolvimento dessas competências internas às empresas de máquinas é puxado pelo setor de calçados e, em muitos casos, tem condições de cumprir mais do que é demandado por grande parte dos usuários. Algumas máquinas da etapa de montagem, por exemplo, incorporam componentes eletrônicos com diferencial tecnológico que algumas empresas de calçados não têm estrutura (financeira ou de formação profissional) para utilizar em seu processo de fabricação.

Além disso, por conta da proximidade de alguns processos com as atividades 
desenvolvidas por outros segmentos de máquinas ou equipamentos eletrônicos, as empresas fabricantes de máquinas para calçados aceleram a difusão de algumas melhorias daqueles segmentos para a indústria calçadista. O controle lógico programável (CLP) ${ }^{75}$ é um exemplo de tecnologia utilizada em outros setores e que tem sido incorporada a alguns modelos de máquinas de montagem de calçados, possibilitando maior interação entre funcionário e máquina sem que ele entre em contato com a navalha.

De maneira geral, as interações entre as empresas de máquina de Franca e Novo Hamburgo e os clientes do setor de calçados estão ajudando, principalmente, no desenvolvimento de competências de produtos como pode ser verificado no quadro 17.

\begin{tabular}{|c|c|}
\hline $\begin{array}{l}\text { Etapas de produção } \\
\text { de calçados }\end{array}$ & $\begin{array}{c}\text { Melhorias a partir das } \\
\text { relações com usuários do setor de calçados }\end{array}$ \\
\hline Design e Modelagem & $\begin{array}{l}\text { - Difusão e/ou incorporação do software Solid Work (usado para o cálculo } \\
\text { das dimensões da máquina e das peças necessárias para executar o } \\
\text { projeto) facilitou a interação com usuários seja na criação ou nas melhorias } \\
\text { das máquinas. }\end{array}$ \\
\hline Corte & $\begin{array}{l}\text { - Máquina de virar corte adaptada para trabalhar com metais; } \\
\text { - Alterações na posição da mesa de um modelo de máquina de alta } \\
\text { freqüência (mesa lateral foi alterada para mesa rotativa) } \\
\text { - Máquina para cortar tiras couro e chapas; }\end{array}$ \\
\hline Costura & $\begin{array}{l}\text { - Máquinas de costura industrial com transporte simples (por dente), } \\
\text { transporte duplo superior por agulha e inferior por dente) e transporte } \\
\text { triplo (superior por agulha e inferior por dente); } \\
\text { - Máquina de costurar solados (blaqueadeiras) para solados de borracha } \\
\text { natural, sintética, pneu, couro e com opção para executar também a } \\
\text { costura lateral de tênis. }\end{array}$ \\
\hline
\end{tabular}

Continua

${ }^{75}$ O Controlador Lógico Programável é dispositivo digital que utiliza memória programável para armazenar instruções e executar funções específicas, controlando máquinas e processos. Esse dispositivo foi criado em 1968, pela empresa General Motors, com o propósito de modificar a lógica de controle dos painéis de comando sempre que ocorria alguma mudança na linha de produção (FILHO, 2006, p. 1). 
Continuação

\begin{tabular}{|c|c|}
\hline $\begin{array}{l}\text { Etapas de produção } \\
\text { de calçados }\end{array}$ & $\begin{array}{c}\text { Melhorias a partir das } \\
\text { relações com usuários do setor de calçados }\end{array}$ \\
\hline $\begin{array}{l}\text { Montagem e } \\
\text { Acabamento }\end{array}$ & $\begin{array}{l}\text { - Máquina para aplicar cola a base de água o (hot melt) com rolos de várias } \\
\text { espessuras para atender as necessidades das empresas de todos os } \\
\text { portes; } \\
\text { - } \text { Estabilizador a frio: os conformadores foram adaptados ao sistema circular; } \\
\text { - Sistema de segurança; } \\
\text { - Secador com baixo consumo de energia; } \\
\text { - Máquina de montar calçados com Controle Lógico Programado } \\
\text { - Máquina para montagem de calçado com tecnologia italiana; } \\
\text { - Adaptação de dispositivos de segurança à linha de produção das } \\
\text { - } \text { - Vaporquizadora - era seriada, mas sobrava muito espaço e não era eficiente; } \\
\text { - Máquinas com regulagens de altura por conta das diferenças regionais; } \\
\text { - Fracionamento das linhas de montar bico (com modelos voltados para } \\
\text { pequenos lotes e máquinas variadas, que são quase customizadas), que } \\
\text { resultou na maior incorporação (de forma mais rápida) de melhorias } \\
\text { incrementais e de propostas realizadas internamente; } \\
\text { - Prensa a frio; }\end{array}$ \\
\hline
\end{tabular}

Fonte: Elaboração própria, com base em pesquisa empírica.

Quadro 17 - Melhorias em produtos e processos a partir das interações entre empresas de máquinas e seus usuários do setor de calçados.

As tecnologias de produtos do setor de máquinas estão em constante mudança, mesmo que com caráter incremental, o que reflete na competitividade das empresas do mercado nacional e externo. Essas melhorias em produtos representam novidades para o mercado nacional, mas não são novidades para o mercado regional (América Latina) porque o perfil tecnológico das empresas latinas, em geral, é de tecnologias relativamente mais simples do que as empresas de calçados com atuação no mercado interno. Adicionalmente, nas empresas de máquinas que têm acordos com os segmentos a jusante e com concorrentes do mercado externo para a transferência de tecnologias, as relações com os clientes também ajudam a validar as melhorias em produtos e a diversificar as linhas de produtos, representando uma novidade no mercado nacional e regional de máquinas para calçados.

Entretanto, há uma heterogeneidade de situações quanto ao modo e/ou intensidade com que as adaptações de produto são realizadas, dependendo do segmento de atuação do fabricante da máquina para calçados. 
Entre as empresas com produção de máquinas destinadas à etapa de corte, o sistema de corte a laser não tem apresentado muitas alterações nos SLPs de Franca e Novo Hamburgo porque os usuários preferem os métodos mais convencionais: as empresas de calçados de pequeno e médio porte não têm capital de giro para investir na aquisição dessas tecnologias e nesse sentido, as melhorias mais freqüentes nas máquinas de corte referem-se à modificações na posição das peças, à possibilidade de trabalhar com outros materiais e de redução no consumo de energia nas máquinas com tecnologia mais simples.

Nas empresas de máquinas para a montagem de calçados, por outro lado, a capacidade de produção precisa ser mais flexível por conta da diversificação dos modelos de calçados e o fracionamento dos lotes de produção.

Atualmente, as máquinas de montar bico apresentam modelos bastante customizados, voltados para pequenos lotes de calçados femininos e vários tipos de bicos. Nas empresas com produção de calçados femininos, as máquinas para montar bico são as que mais apresentam alterações porque o formato dos bicos muda muito de uma estação para outra. Por conta dessa maior flexibilidade na fabricação de calçados, algumas empresas do setor de máquinas têm investido no fracionamento dos lotes de produção (um lote com 100 máquinas para 10 lotes com cinco máquinas, por exemplo), o que facilita a incorporação de melhorias incrementais de forma mais rápida. Entretanto, as máquinas de montar precisam ser reguladas constantemente e nem sempre a necessidade do usuário é atendida: às vezes, a modificação é realizada pelo técnico da empresa usuária das máquinas ${ }^{76}$.

No segmento de máquinas de injeção de plásticos, o produtor não precisa mudar a máquina porque as alterações nos modelos de calçados determinam apenas a utilização de novos moldes, o que não interfere diretamente no desempenho da máquina. Além disso, as melhorias efetuadas por injetoras de plástico são determinadas mais por empresas de outros ramos industriais como brinquedos, utilidades domésticas e indústria automotiva. Por esse motivo, as injetoras de plástico podem ser classificadas como produtos mais commoditizados porque apresentam maior concorrência em custos do que em adaptação aos pedidos do usuário final.

\footnotetext{
${ }^{76}$ Outro exemplo é o das empresas com produção de máquinas de pintura de salto e os secadores, que apresentam várias alterações incrementais a partir das sugestões dos usuários no momento do uso, visto que o que é necessário e útil para uma empresa de calçados, pode não ser para outra
} 
As tecnologias de processo no setor de máquinas não estão em constante mudança, apenas se adaptaram sem ganhos no processo de produção, porque o projeto das máquinas é reformulado de acordo com as exigências dos usuários, retirando ou adaptando componentes sem representar saltos tecnológicos para o setor de máquinas ${ }^{77}$.

Nas empresas de máquinas para a montagem de calçados, recentemente a utilização de sistemas hidráulicos em substituição aos sistemas pneumáticos tornou-se um diferencial do setor de máquinas no mercado nacional e regional ${ }^{78}$. Além disso, os sistemas elétricos de comando, utilizados para digitar e regular a posição, também facilitam as operações do setor no mercado nacional, porém muitos funcionários nas empresas de calçados não sabem operar adequadamente essas máquinas.

De maneira geral, as empresas de máquinas implantaram (ou consolidaram) células de trabalho visando a redução de estoques de peças e como de forma minimizar o tempo de produção desde a usinagem até a etapa de pintura. Nesse sentido, como o set up das empresas melhorou, elas podem produzir relativamente mais, e com prazo de entrega menor.

Outra estratégia interessante é a organização de subgrupos de trabalho com pelo menos um funcionário especializado que conhece e controla todas as funções de produção. Cada máquina é subdivida entre vários funcionários que ajudam a aplicar as sugestões dos usuários e transformá-la em melhorias. Porém, é o funcionário com conhecimentos especializado que decide se vai adaptar ou manter a configuração padrão da máquina.

Por conta dessas características das tecnologias de produto e de processo do setor de máquinas para calçados, a inovação predominante desenvolvida nas empresas de máquinas dos dois SLPs é a inovação de produto, e em alguns casos, a inovação de produto e processo. A principal justificativa para essa característica é

\footnotetext{
empresa.

${ }^{77}$ O software Solid Work utilizado no design e modificações do projeto das máquinas tem aumentado a qualidade do produto e diminui as chances de erros na produção de calçados.

${ }_{78}$ De acordo com informações coletadas da pesquisa de campo, atualmente há trinta empresas no mundo com produção de máquina para montagem na mesma linha de uma empresa visitada, sendo que três apresentam sistemas pneumáticos e 27 são hidráulicas. Dentre as três com sistemas pneumáticos, duas estão no Brasil; e dentre as hidráulicas, apenas a empresa visitada tem atuação no Brasil e América Latina.
} 
que as relações estabelecidas com usuários ampliaram relativamente pouco as condições para o desenvolvimento dos conhecimentos em processo, e em muitos casos, a contribuição é instável, porque depende das flutuações do mercado interno.

Adicionalmente, as melhorias de produto são apresentadas em intensidade relativamente maior que as melhorias de processo, o que é justificado pelo perfil de desenvolvimento tecnológico da indústria calçadista que é realizado em etapas, dada a característica segmentada da atividade produtiva. Nesse sentido, a dinâmica de desenvolvimento de produtos e processos da indústria de máquinas para calçados pode variar significativamente, de acordo não só com o segmento de atuação das empresas de máquinas, mas com o perfil e as características dos fabricantes de calçados.

\subsection{Fatores que interferem na capacidade de absorção de conhecimentos a partir das relações com os usuários da indústria de calçados}

As empresas de máquinas para couro e calçados de Novo Hamburgo e Franca têm apresentado bons resultados a partir das interações com usuários do mercado nacional de calçados, relativamente ao desempenho dos concorrentes de outros países - prova disso é que o setor é o segundo maior fornecedor mundial de máquinas para calçados, atrás da Itália que é referência nesse ramo.

Em termos comerciais, mesmo com as dificuldades internas e externas às empresas de máquinas, o setor melhorou consideravelmente a sua participação no mercado externo, com o crescimento expressivo das exportações nos últimos anos. Paralelamente, grande parte da produção do setor mantém o perfil das vendas para o mercado interno, a partir das interações e assistência técnica oferecida para usuários dos principais SLPs de calçados.

Além disso, as empresas de máquinas também têm apresentado melhorias de sua base técnica e da qualidade dos produtos; estão fortalecendo a marca em outros mercados - através da participação em feira e eventos internacionais - e têm ampliado algumas aptidões em atividades nas quais as empresas dependiam mais de fontes externas.

Entretanto, há um conjunto de fatores que interfere no dinamismo da relação 
entre usuários e produtores de máquinas e que podem refletir na criação de competências dos segmentos de máquinas no longo prazo.

As relações usuário-produtor apresentam características distintas dependendo do porte da empresa usuária das máquinas: empresas de calçados que trabalham com lotes pequenos e poucas variações nas linhas dependem relativamente menos dos produtores de máquinas que as empresas que trabalham com lotes maiores de calçados.

As empresas de pequeno porte dificilmente recorrem às empresas de máquinas para solicitar alguma adaptação desses produtos por conta de três fatores levantados em visitas junto às empresas:

- Os preços cobrados pela assistência técnica da máquina são altos para os usuários;

- Os problemas mecânicos são resolvidos pelos próprios funcionários da empresa de calçados (em geral não são mecânicos);

- Os lotes pequenos de calçados dificultam a diluição dos custos na adaptação das máquinas;

Mas mesmo nas empresas de calçados de médio e grande porte, as interações com fabricantes de máquinas também podem ser dificultadas. Nas empresas de calçados femininos, por exemplo, o layout muda muito de uma estação para outra e mesmo dentro de uma mesma estação - por conta da variedade da linha de produtos - e a posição das máquinas de montar saltos e bicos (as máquinas mais importantes para calçados femininos) tem que ser realocadas freqüentemente. Por conta desse fator, as empresas fabricantes de calçados preferem recorrer aos seus mecânicos internos para a resolução de problemas técnicos ou a adaptação de melhorias incrementais.

De maneira geral, os investimentos em tecnologias por parte dos usuários são direcionados mais para adequar as máquinas de calçados às variações dos lotes. Como o processo de fabricação de calçados masculinos é relativamente mais simples que a produção de calçados femininos, há algumas diferenças regionais nas preferências atendidas por empresas de máquinas também do sul, como a adaptação ou alteração de posição de alguns componentes, que precisam ser reavaliadas no atendimento das empresas de calçados de Franca. Por esse motivo, as condições de oportunidade para incorporar melhorias ao sistema produtivo das empresas de máquinas estão diretamente ligadas à capacidade de averiguar e 
explorar as oportunidades e dificuldades das empresas usuárias em cada região.

As fontes de financiamento utilizadas por empresas de máquinas para calçados são predominantemente de capital próprio ${ }^{79}$ e as empresas não têm orçamento anual fixo para direcionar os investimentos em maquinário: os departamentos canalizam os recursos de acordo com as necessidades do mercado e as perspectivas de vendas ${ }^{80}$.

Atualmente os investimentos das empresas de máquinas para calçados são direcionados à diversificação dos mercados atendidos, principalmente para a América Latina e Ásia, a partir da participação em feiras com o apoio da ABRAMEQAPEX. E num único caso, a empresa também tem destinado parte de seus gastos à diversificação dos produtos, com queda expressiva da participação das máquinas para calçados no total do faturamento.

Outra estratégia ressaltada pelas empresas de máquinas é a aquisição de máquinas nas etapas de fresa e usinagem, o que pode indicar uma tendência a reduzir a externalização das atividades nessas etapas de usinagem.

Os cursos de formação e capacitação dos funcionários nas empresas de máquinas são pouco destacados pelas empresas de máquinas para couro e calçados, por conta do baixo nível de mudanças técnicas (de processo) do setor.

Em geral, as empresas de máquinas têm acordos com escolas técnicas e profissionalizantes como o SENAI e a Escola Técnica Liberato (Novo Hamburgo), em que recorrem a funcionários com formação técnica básica e treinam esses funcionários de acordo com as práticas internas à empresa ${ }^{81}$. Além disso, as empresas recorrem aos cursos de capacitação que são realizados, principalmente, fora da empresa, através da participação dos fornecedores de tecnologias e de insumos visando o treinamento e atualização dos funcionários em informações específicas, que posteriormente são repassadas para a empresa.

Cabe ressaltar que desde meados dos anos 90, as empresas nacionais de máquinas para calçados apresentam modelos mais customizados, voltados ao atendimento das necessidades específicas do mercado consumidor, e com preços

\footnotetext{
79 Apenas duas empresas citaram outros meios de financiamento (parcelamento junto aos fornecedores e financiamentos voltados à modernização).

${ }^{80}$ E uma das empresas destacou que não tem capital de giro e que os investimentos em máquinas e tecnologias dependem do faturamento da empresa no curto prazo.

${ }^{81}$ Uma única empresa tem um projeto em andamento, em que patrocina a conclusão dos cursos secundários e a graduação, desde que seja em alguma área próxima à atuação na empresa,
} 
relativamente mais baixos que as máquinas italianas.

Entretanto, nos últimos anos o Brasil tem enfrentado forte concorrência na produção internacional do setor. Algumas empresas nacionais de alguns segmentos de máquinas para calçados têm apresentado dificuldades para produzir máquinas customizadas com a mesma escala de produção e preços dos fabricantes de máquinas dos países asiáticos. Particularmente nos últimos três anos, o segmento de máquinas para couro e calçados nacional passou a enfrentar maior concorrência com produtores de máquinas da China, nos segmentos de máquinas injetoras de plástico, máquinas de costura e nas máquinas de corte que têm apresentado preços relativamente mais competitivos no comércio mundial de máquinas.

Os representantes de empresas chinesas têm penetrado principalmente nos mercado latino americano, nos mercados consumidores das máquinas brasileiras do México e da Argentina e tem ampliado sua inserção nos mercados de máquinas de outros países, principalmente nos segmentos de baixo conteúdo tecnológico. Isso tem repercutido na queda sistemática das vendas de algumas empresas nacionais no mercado externo.

Nos segmentos de máquinas de corte, por exemplo, os preços praticados pelos produtores chineses são cerca de $40 \%$ menores que os produtos nacionais. Além disso, as empresas asiáticas fabricam balancins com qualidade bastante inferior, mas estão avançando rápido e já têm produzido balancins com tecnologias intermediárias $^{82}$.

Outro segmento que tem apresentado forte concorrência com os produtos chineses é o de injetados para calçados. Como o custo é o atributo mais importante para a competitividade das empresas deste segmento, as empresas chinesas têm conseguido ampliar as vendas principalmente entre os modelos de máquinas e configuração com custos mais reduzidos. Além disso, as empresas nacionais de injetados têm apresentado dificuldades para competir com as escalas elevada de produção de máquinas de outros países - hoje o mercado interno tem um total de 29

\footnotetext{
visando a melhor capacitação dos funcionários.

82 Uma empresa nacional de máquina para calçados desenvolveu parceria comercial e tecnológica com empresa italiana para o desenvolvimento de uma linha de máquinas para corte. Após o término da parceria, a empresa estrangeira instalou uma unidade produtiva no mesmo SLP em que brasileira atua e revende máquinas fabricadas na China. Nesse caso, a empresa italiana tornou-se a principal concorrente da fabricante brasileira de máquinas em custo e qualidade porque revende máquinas fabricadas na China com a tecnologia italiana.
} 
concorrentes de outros países.

Por outro lado, as empresas brasileiras de máquinas de outros segmentos não têm enfrentado problemas para entrar no mercado externo, em especial na América Latina: as empresas nacionais apresentam elevada facilidade para adaptar sua capacidade produtiva aos requerimentos tecnológicos daqueles países, ao contrário das empresas de máquinas chinesas, que têm sua competitividade definida pela escala de produção.

No segmento de balancins e máquinas de montagem que são críticos para todo o processo de produção, as empresas da China não têm focado a participação no mercado brasileiro porque o seu único atrativo ainda é o preço. Há um desnível tecnológico significativo do setor de calçados da China, o que dificulta o desenvolvimento das suas máquinas. Nesse sentido, algumas empresas chinesas têm procurado as brasileiras porque têm interesse em vender máquinas chinesas sem marcas próprias, mas o negócio não é viável para o mercado interno por conta da falta de garantias quanto à qualidade dos produtos ${ }^{83}$.

Para amenizar os efeitos da concorrência chinesa sobre seu desempenho comercial, as empresas nacionais de máquinas estão investindo em outros mercados, especialmente a Índia e África do Sul, por meio da participação em feiras voltadas à promoção comercial. Além disso, as empresas brasileiras estão atentas ao nível de penetração das empresas chinesas no mercado interno e externo com o objetivo de não deixar que os chineses avancem em segmentos estratégicos para o desempenho do setor.

Cabe ressaltar que há muitas máquinas chinesas trazidas pelos clientes do mercado interno com garantias para durar pelo menos até o fim do lote de calçados. A qualidade e durabilidade das máquinas, nesses casos, não é um fator de interesse para os usuários, então os fabricantes chineses de máquinas podem explorar esses segmentos de calçados mais sazonais em que os produtores de calçados têm a característica de não querer assumir os custos com máquinas de melhor qualidade.

\footnotetext{
${ }^{83}$ Outra empresa está estudando a viabilidade de uma parceria com empresas de máquinas para produzir na China, mas como a tecnologia é de baixa qualidade, os produtores de calçados preferem não arriscar em aquisições da China.
} 


\section{Conclusão}

O conhecimento e a inovação são fatores que exercem importância cada vez maior para o desempenho econômico e o desenvolvimento industrial de empresas e setores. Seu papel está vinculado à incorporação de novas possibilidades para a resolução de problemas técnicos e através da manutenção de capacitações e atributos competitivos no longo prazo.

As características da tecnologia e os mecanismos utilizados para o aprendizado, a partir de interações sociais, são os principais aspectos do processo de inovação, que contribuem para a dinâmica produtiva e tecnológica de empresas e setores. De um lado, as características do conhecimento-base, as condições de cumulatividade e o nível de apropriação das informações tecnológicas diferem consideravelmente entre as empresas, o que contribui para modificações nas condições de oportunidade para criar e incorporar melhorias técnicas e tecnológicas nos setores ao longo do tempo. De outro lado, a forma como os agentes incorporam e difundem melhorias ao longo do tempo, por sua vez, também interfere nas capacitações técnico-produtivas e no desenvolvimento industrial porque, através das interações sociais, esses agentes desenvolvem novas habilidades competitivas e melhoram sua capacidade de absorção de conhecimentos.

Cabe ressaltar que enquanto os mecanismos de aprendizado interno às empresas ajudam na organização e reconfiguração de informações voltadas à resolução de problemas técnicos e de melhorias na produção; o aprendizado externo às empresas, principalmente de caráter vertical, pode intensificar a acumulação de competências e alavancar as capacidades de absorção de conhecimentos ao longo das cadeias. Nesse sentido, a principal contribuição dos mecanismos de aprendizado é que eles acentuam os fluxos de informações e o adensamento das relações inter-empresas, refletindo tanto em mudanças de caráter incremental como na trajetória tecnológica das empresas e setores.

As interações verticais entre usuários e produtores contribuem para a criação de competências e para o incremento da capacidade de absorção de conhecimentos, facilitando o compartilhamento de informações de caráter tácito e codificado intrafirma, embora apresentem uma característica descontínua e elevado 
grau de incerteza. De um lado, a interação estabelecida com usuários acentua as condições para a incorporação de melhorias aos produtos e processos e facilita o desenvolvimento de habilidades competitivas no longo prazo. De outro, o contato com produtores permite a incorporação de inovações incrementais (provenientes de outros setores) que estão voltadas à resolução de problemas, ao desenvolvimento de novos produtos e à atualização tecnológica do processo de fabricação de produtos das empresas usuárias.

A indústria brasileira de bens de capital apresenta uma heterogeneidade em sua estrutura produtiva e de oferta e conta com níveis distintos de capacitação e desenvolvimento tecnológico que são relevantes para a incorporação e difusão de melhorias ao longo das cadeias industriais.

De maneira geral, a indústria produz máquinas seriadas em grande escala que apresentam relativa padronização de projeto e pouco espaço para alterações incrementais de produto ou processo; e máquinas sob encomenda - que são desenvolvidas com significativa sofisticação tecnológica e contam com elevado envolvimento entre fabricantes e usuários na etapa de projeto.

A segmentação na produção das máquinas se reflete na estrutura de oferta com empresas de vários portes e com distintos graus de barreiras à entrada: em geral, as empresas com produção de bens de capital seriados utilizam tecnologias mais maduras e apresentam baixas barreiras à entrada, enquanto as empresas com fabricação de máquinas sob encomenda, por sua vez, têm mais condições para promover a atualização tecnológica de seus produtos ou contam com a participação de outras empresas para a incorporação de melhorias e, por esse motivo, apresentam elevada barreira à entrada de outros concorrentes.

O modo e a intensidade com que as empresas de máquinas têm incorporado informações à sua trajetória interferem no nível de capacitação tecnológica da indústria de bens de capital e refletem as características das interações a jusante e a montante estabelecidas ao longo das cadeias. As empresas com produção de máquinas sob encomenda, por exemplo, contam com maior participação dos usuários no desenvolvimento e modificação de projetos. Nesse sentido, apresentam uma forte tendência a acumular, relativamente, mais competências tecnológicas em produtos e processos do que as empresas de máquinas seriadas. Porém, mesmo nesses segmentos de máquinas seriadas, os mecanismos de aprendizado interativo podem contribuir para a maior flexibilidade na produção e adaptação de produtos, 
dependendo do nível de cumulatividade do conhecimento-base no interior das empresas de máquinas.

É importante ressaltar que as flutuações no cenário macroeconômico têm interferido nas expectativas empresariais do mercado interno e externo, determinando variações dos investimentos na produção e modernização dos segmentos de bens de capital.

De um lado, a instabilidade econômica e seus efeitos sobre as taxas de investimento geral podem resultar na restrição dos investimentos produtivos, numa dimensão relativamente maior do que em outros setores industriais, acentuando a heterogeneidade produtiva e de oferta dos segmentos de máquinas.

De outro lado, a crescente participação de outros países na produção internacional de máquinas também interfere no nível de investimentos voltados à expansão da capacidade produtiva, na relocalização das unidades fabris para outros mercados e na especialização em outros nichos de produtos. Entretanto, ambos os aspectos - comportamento elasticamente pró-cíclico da demanda de bens de capital e a participação de outros países na produção mundial de máquinas - não anulam as condições para a criação e incorporação de competências em produtos e processos no interior das empresas nacionais de máquinas, principalmente naqueles segmentos formados por empresas de pequeno e médio porte, com atividades voltadas, sobretudo ao atendimento de aglomerações de empresas.

De maneira geral, o aprendizado de tecnologias e processos do setor de máquinas não depende exclusivamente de investimentos vultuosos realizados por suas empresas, porque as inovações têm caráter incremental e são realizadas gradualmente, a partir do aprendizado interativo com fontes externas de informação. Além disso, como os segmentos de máquinas são difusores de tecnologias para outros setores, esse aprendizado vai depender, em grande medida, do adensamento das interações ao longo das cadeias.

$\mathrm{Na}$ indústria brasileira de bens de capital para calçados, as empresas de máquinas têm suas decisões de produção afetadas pelas flutuações no nível de investimentos, mas a dinâmica de aprendizado de novas competências é explicada, em grande medida, por outros fatores da dinâmica industrial do setor de calçados.

Em primeiro lugar, o desempenho das empresas de bens de capital para calçados é determinado pelas necessidades de abastecimento dos seus usuários do setor de calçados: as variações na demanda nacional e mundial de calçados 
refletem diretamente na aquisição de máquinas, seja para a ampliação da capacidade produtiva ou para a modernização tecnológica, embora a oferta do mercado de máquinas recondicionadas também interfira nessa demanda da indústria de máquinas para calçados.

Em segundo lugar, o desenvolvimento da cadeia de calçados em sistemas locais de produção (SLPS) interfere positivamente no desempenho econômico e industrial e no padrão de competitividade das empresas de máquinas para calçados. Como os SLPs foram constituídos a partir da proximidade geográfica e identidade cultural entre agentes de todos os segmentos e contam com presença de economias externas localizadas, de caráter incidental e deliberadas, os SLPs constituem um importante lócus para as interações e o aprendizado inovativo das empresas de máquinas.

Cabe ressaltar que os segmentos de máquinas também contribuem para 0 desenvolvimento dos SLPs porque através das interações interfirmas estabelecida ao longo da cadeia, as empresas de máquinas facilitam a integração entre subsistemas de produção e de conhecimento dos SLPS, acentuam a difusão de habilidades internas às empresas e determinam uma variedade de condições para melhorias de produtos e processos, assim como promovem o desenvolvimento de novas capacitações nos interior dos SLPs.

Por outro lado, o setor de calçados apresenta uma heterogeneidade de estruturas competitivas que são explicadas, principalmente, pela segmentação do mercado de calçados - com vários tipos e modelos de calçados - e pela segmentação da oferta - as empresas de pequeno e médio porte apresentam diferentes atributos produtivos e níveis de especialização tecnológica. E essas estruturas competitivas freqüentemente modificam a integração entre os subsistemas de produção e de conhecimentos e o aprendizado incremental inovativo das empresas de máquinas.

O desenvolvimento tecnológico do setor de calçados no Brasil foi determinado, em grande medida, pela inserção de empresas nacionais em redes globais para a comercialização de calçados sem marcas próprias - o que imprimiu modificações significativas na organização e adoção de novas técnicas produtivas. Além disso, a incorporação de novos materiais e matérias-primas alternativas ao couro repercutiu no adensamento das relações com outros segmentos, em especial a indústria química e de máquinas. 
Nos últimos anos, a instabilidade econômica e a crescente participação de empresas chinesas no mercado internacional de calçados têm contribuído para a intensificação de esforços na área comercial, a partir da criação e do fortalecimento das marcas brasileiras no mercado interno e externo.

Adicionalmente, as empresas da cadeia de calçados têm acentuado as estratégias produtivas voltadas à incorporação de equipamentos com maior diferencial competitivo, especialmente em termos de produtividade e flexibilidade para trabalhar com lotes pequenos e variados. Mas como a automação do setor de calçados ocorre a partir de avanços incrementais realizados de maneira irregular em virtude da elevada divisibilidade das etapas de produção e das diferentes condições financeiras e competitivas das empresas de calçados - a atualização tecnológica do setor é realizada, principalmente, nas etapas com mais dificuldades para trabalhar com variações sazonais dos modelos de calçados.

Por conta desses fatores, a indústria brasileira de máquinas para calçados tende a apresentar desempenho comercial marcado por significativas flutuações da demanda no mercado interno e externo, e nos últimos anos, tem investido na manutenção e na abertura novos canais para a venda de seus produtos, contando com o apoio das instituições de apoio ao setor.

Em termos do desenvolvimento tecnológico, as empresas de máquinas são caracterizadas pela variedade tecnológica de máquinas fabricadas sob encomenda, visando atender a diferentes faixas de renda e necessidades distintas do mercado interno. Na década de 90, algumas empresas do setor de máquinas para calçados realizaram acordos com concorrentes de outros países, como forma de acentuar a incorporação de novas tecnologias às suas máquinas, muito embora no período recente esses acordos não œjam a principal fonte de atualização tecnológica do setor. Mas na maioria das empresas de máquinas, a intensificação das interações com empresas nacionais de etapas a jusante e a montante, tornourse o principal mecanismo para atender à demanda dos usuários, e adicionalmente, ampliar as capacitações internas em produtos e processos.

Para identificar, caracterizar e analisar esses aspectos das relações usuárioprodutor, este trabalho de pesquisa realizou estudos empíricos junto a empresas de máquinas para calçados, empresas com fabricação de calçados e instituições de apoio ao setor nos SLPs do Vale do Sinos (RS) e de Franca (SP).

O principal aspecto do desenvolvimento industrial e competitivo das empresas 
de máquinas para calçados é que, nos últimos anos, elas têm apresentado diferenças na dinâmica de aprendizado interativo interno e externo. Enquanto o aprendizado interno às empresas de máquinas apresenta um perfil homogêneo; o aprendizado de fontes externas, principalmente a partir de contatos estabelecidos com usuários, pode variar um pouco em função do uso das máquinas (ou segmentos de atuação) e da estrutura competitiva das empresas usuárias do setor de calçados.

O aprendizado interativo interno às empresas de máquinas ocorre, principalmente a partir de reuniões interdepartamentos de caráter informal e formal (em menor grau) - em que os funcionários discutem problemas técnicos e novas possibilidades e aplicações de produtos e processos; e durante a produção das máquinas - os funcionários responsáveis pelo projeto das máquinas, a equipe da assistência técnica e a engenharia testam as melhorias solicitadas pelos usuários e/ou trazidas pelos fornecedores de insumos.

A baixa rotatividade do emprego nessas áreas tende a acentuar a especialização e a cumulatividade dos conhecimentos internos que estão concentrados nesses funcionários. Entretanto, são comuns as soluções com alto custo de produção, que as empresas estão tentando resolver a partir da revisão dos projetos e do gerenciamento do processo de fabricação.

O aprendizado interativo de fontes externas, por sua vez, pode ser realizado, em menor grau, através de acordos com fornecedores de insumos, concorrentes do mercado externo e interno e, principalmente, a partir dos vínculos estabelecidos com usuários da cadeia de calçados.

O aprendizado a partir do contato com empresas fornecedoras de insumos e componentes eletrônicos tem funcionamento moderado porque em geral, esses contatos são estabelecidos mais para fins comerciais e apenas em alguns casos, contribuem para a criação de capacitações nas empresas de máquinas: as melhorias e as capacitações para trabalhar com máquinas mais produtivas e flexíveis da etapa de montar bico são explicadas, em grande medida, por contatos com os fornecedores de componentes eletrônicos e de automação.

Os concorrentes do mercado externo, em especial as empresas italianas e alemãs, têm exercido papel menos relevante nas estratégias de aprendizado tecnológico das empresas brasileiras, de acordo com a finalidade da máquina nacional. Nos últimos anos, as empresas de máquinas para as etapas de montagem têm mais necessidade de acessar e incorporar inovações incrementais a partir 
dessas fontes, porque essas melhorias não estão disponíveis ou porque o componente é mais caro no mercado interno. Além disso, essa etapa de montagem é a que sofre mais modificações por conta da sazonalidade da produção de calçados e das variações nos modelos de calçados.

As interações mantidas com os concorrentes do mercado interno têm como principal propósito a inserção das empresas brasileiras de máquinas no comércio internacional, ou são determinadas pela necessidade de formar consórcios para a compra de insumos a preços mais acessíveis para as empresas brasileiras. Esse tipo de contato intra-empresa tem resultado em pouco (ou nulo) aprendizado porque as empresas não incorporam competência de produtos com a participação conjunta em outros mercados, mas agregam conhecimentos sobre o funcionamento dos mercados (potenciais) e reforçam sua capacidade de adaptação às necessidades dos usuários de níveis distintos de desenvolvimento industrial.

É importante ressaltar que as interações realizadas com usuários dos SLPS de calçados são o principal mecanismo para o acesso a informações tecnológicas externas às empresas de máquinas, para a incorporação de melhorias incrementais em produtos e processos e para o desenvolvimento de habilidades entre as empresas de máquinas.

De maneira geral, as características do aprendizado interativo interno e externo às empresas de máquinas nos últimos anos resultaram em um regime tecnológico com especialização e alta divisibilidade dos conhecimentos internos às empresas de máquinas; e em alto grau de oportunidade para a realização de inovações incrementais, que é explicada, em grande medida, pela elevada cumulatividade das informações técnicas e de produtos no interior dos fabricantes de máquinas. Porém, como as empresas estão inseridas em sistemas locais com elevada difusão de informações e de conhecimento, o grau de apropriação das informações tecnológicas tende a ser relativamente mais baixo.

O aprendizado interativo com os usuários das máquinas é explicado pela proximidade geográfica e cultural entre as empresas e pelos canais de comunicação estabelecidos com recíproca confiança entre os agentes. Além disso, os fluxos de conhecimento são realizados com elevada freqüência, o que se reflete em informações técnicas e melhorias incorporadas ao conhecimento-base interno às empresas de máquinas.

Por outro lado, há algumas diferenças no aprendizado usuário-produtor 
em virtude dos fatores de competitividade dos segmentos de máquinas e da estrutura industrial das empresas de calçados que tornam esse processo de aprendizado bastante heterogêneo no interior dos SLPs.

Em primeiro lugar, os fatores de competitividade dos segmentos de máquinas referem-se aos atributos mais relevantes para seu desempenho comercial, de acordo com a sua finalidade.

Os segmentos de máquinas para calçados dos SLPs de Franca e de Novo Hamburgo podem ser classificados por apresentar máquinas customizadas e commoditizadas. As máquinas customizadas têm sua competitividade determinada pelo desempenho e qualidade dos produtos e nos quais as empresas apresentam boas condições para a assistência técnica e para a incorporação de melhorias incrementais às máquinas. Já as máquinas mais commoditizadas, têm a competitividade baseada, principalmente, no preço das máquinas e embora apresentem uma base interna voltada à incorporação de melhorias, a baixa automação das etapas de fabricação de calçados em que elas concentram suas atividades afins reflete em mais dificuldades para o desenvolvimento tecnológico e o desempenho comercial.

Em ambos os segmentos - customizados ou commoditizados - as empresas brasileiras de máquinas para calçados apresentam diferencial competitivo no mercado interno e regional por conta da flexibilidade para atender aos requisitos dos usuários. Entretanto, como em alguns segmentos (máquinas para montagem, por exemplo) a adaptação e as inovações incorporadas às máquinas são relativamente mais requeridas para a resolução de problemas na fabricação de calçados do que em outros segmentos (máquinas de costura industrial, entre outras), então as interações usuário-produtor são realizadas com maior regularidade naqueles casos.

Adicionalmente, as empresas de máquinas customizadas têm mais condições de sustentar seu desempenho comercial diante da concorrência no mercado interno e externo, porque as empresas apresentam maior variabilidade de modelos de máquinas com níveis tecnológicos distintos. A capacidade de absorção de novos conhecimentos torna-se relativamente maior por conta da expressiva intensidade das interações com os usuários.

As empresas de máquinas commoditizadas, por outro lado, também apresentam atributos competitivos importantes para o seu desenvolvimento e a atuação no comércio internacional de máquinas. Porém, como a sua capacidade de 
absorção de informações tende a ser menor em virtude da intensidade do aprendizado interativo com seus usuários, a empresa de máquinas commoditizadas tem mais dificuldades para garantir a participação de suas vendas no mercado interno e externo.

Em termos regionais, as empresas de máquinas customizadas e commoditizadas dos dois SLPs também apresentam algumas variações na relação com seus usuários da cadeia de calçados: em geral, as empresas de máquinas de Novo Hamburgo dispõem de uma estrutura mais densa de relações horizontais e verticais, com forte caráter incremental. Em Franca, as empresas de máquinas também têm vínculos com fornecedores e com usuários, mas esses contatos ocorrem principalmente a partir dos serviços de assistência técnica oferecidos no perío do de demonstração ou de garantia da máquina.

As empresas de máquinas do Vale do Sinos também têm realizado mais interações com os fornecedores de outros segmentos, seja para a aquisição de insumos ou para a incorporação de componentes eletrônicos e o aprendizado de novas tecnologias. Esse aspecto pode sinalizar algumas distinções na dinâmica industrial e competitiva das empresas das duas regiões uma vez que as empresas de Novo Hamburgo, especialmente aquelas com atividades da etapa de montagem, incorporam mais inovações de processo do que as empresas da aglomeração espacial de Franca.

A articulação entre as empresas locais de máquinas das duas regiões para a criação de novos canais de comércio com usuários de outros mercados também apresenta algumas distinções: as empresas de Novo Hamburgo têm participação mais sistemática nas feiras do setor relativamente às empresas de máquinas localizadas na cidade de Franca; e têm exportado, embora de maneira bastante esporádica, para países com elevado potencial para adquirir máquinas brasileiras, como a Índia.

Em segundo lugar, o dinamismo dos sistemas locais em que as empresas de calçados estão inseridas e as diferenças na sua estrutura de produção e de oferta das empresas de calçados também interferem no aprendizado interativo com os fabricantes de máquinas.

As empresas de calçados de grande porte e/ou com atividades localizadas em sistemas mais dinâmicos tendem a apresentar vínculos mais consistentes com os fabricantes de máquinas, seja para a resolução de problemas técnicos ou para as 
melhorias das máquinas. Em geral, essas empresas de calçados apresentam um planejamento da manutenção das máquinas e de modificações do layout de maneira mais sistemática (não apenas quando há variações nos modelos de calçados). Essas características facilitam a troca de informações com os produtores de máquinas visando o aumento da produtividade e a atualização do maquinário e das tecnologias empregadas na fabricação dos calçados.

As empresas de calçados de pequeno e médio porte e/ou localizadas em sistemas menos dinâmicos, por sua vez, têm mais restrições econômicas para recorrer aos fornecedores de máquinas para calçados: de um lado, o baixo capital de giro para contratar serviços de assistência técnica, as dificuldades para realizar a manutenção das máquinas e as exigências para apresentar lotes pequenos de calçados com elevada variabilidade de modelos limitam o contato com os usuários então os próprios funcionários das empresas de calçados (em geral, os mecânicos) resolvem os problemas técnicos das máquinas. Nesse sentido, as empresas de calçados contam com seus mecânicos ou gerentes da produção de calçados, recorrendo aos fabricantes das máquinas somente nas situações em que não conseguem resolver problemas técnicos que podem travar a produção.

Entretanto, é necessário destacar que a estrutura produtiva e o tipo de especialização das empresas de calçados interferem mais nas relações com os fornecedores de máquinas (principalmente nas máquinas para montagem) do que as restrições econômicas dos usuários.

Os calçados masculinos não apresentam o mesmo nível de dificuldades técnicas e produtivas apresentadas na fabricação de calçados femininos porque têm menor variabilidade de modelos e a sazonalidade dos calçados masculinos não é tão pronunciada. Em contrapartida, as máquinas destinadas a etapas como a montagem de bico e de salto em calçados femininos, por exemplo, precisam adaptar-se às variações do tamanho dos lotes, à variabilidade dos modelos e à sazonalidade da demanda no mercado interno e externo. Por conta desses fatores, a interação entre empresas de máquinas da etapa de montagem e de calçados femininos são mais requisitadas do que entre empresas com fabricação de máquinas de outras etapas do processo produtivo de calçados.

Cabe ressaltar que as empresas de máquinas dos dois SLPs apresentam uma característica homogênea em termos de formação profissional e de restrições financeiras das empresas de máquinas. 
Um aspecto comum entre as empresas é que œmo elas estão inseridas em sistemas locais com elevada integração entre produção e conhecimentos, podem contar com instituições de ensino que oferecem cursos básicos de formação profissional. Já a atualização profissional é realizada, principalmente, no ambiente interno às empresas de máquinas, durante a fabricação das máquinas, e a partir do contato com fontes externas de informação. Em alguns casos, as empresas de máquinas recorrem a eventos promovidos por instituições de apoio e aos contatos com fornecedores de componentes para adquirir os conhecimentos sobre o funcionamento de novas tecnologias.

Em segundo lugar, os fabricantes de máquinas apresentam baixo capital de giro para investir na incorporação e adaptação de tecnologias mais avançadas às suas máquinas, e têm investido grande parte de suas vendas na participação em feiras e eventos, visando à manutenção de seu desempenho e a abertura de novos canais de comércio no mercado interno e externo. Além disso, a maioria das empresas não têm acesso à fontes de financiamento para o desenvolvimento tecnológico porque as exigências dos programas de financiamento não cobrem as dificuldades e especificidades das pequenas e médias empresas do ramo de máquinas para calçados.

As flutuações macroeconômicas dificultam sobremaneira a atuação das empresas de ambos os segmentos, por meio das variações da demanda por calçados e dos investimentos na ampliação e modernização da capacidade produtiva das máquinas. Porém, mesmo nesse cenário, a participação das empresas de máquinas e de calçados em sistemas bcais de produção apresenta um duplo papel sobre a sua dinâmica de inovação: de um lado, o produtor de máquinas tem integrado os sistemas de produção e de conhecimento no interior das aglomerações espaciais; e de outro, a participação mais sistemática dos usuários em alguns segmentos ajuda a dinamizar o desenvolvimento tecnológico das máquinas.

Dessa forma, a presença dos sistemas locais acentua a realização de interações usuário-produtor e têm ajudado no desenvolvimento de novas capacitações internas às empresas de máquinas, podendo funcionar, inclusive, como instrumento de proteção à concorrência internacional, principalmente nos segmentos de máquinas mais customizadas. 


\section{Referências Bibliográficas}

AAGE, T. (2005) Boundary spanning strategies of industrial districts: the impact of absorptive capacity. In: FIORENZA, Belussi e SAMMARRA, Alessia. Industrial Districts, Relocation, and the Governance of the Global Chain. Cap. 05, p. 109-121, Dez/2005. No prelo.

ABIMAQ ABRE escritório para negociar na China. Notícias (Jun/06). Revista Plástico Moderno. n. 380. Disponível em: http://www. plastico.com.br/indice.htm. Acesso em: 30 ago., 2007.

ABRAMEQ TRARÁ visitantes de países estratégicos para a 30ª FIMEC (27/mar/06). ABRAMEQ. Disponível em:

http://www.global21.com.br/materias/materia.asp?tipo=noticia\&cod=10728

A CHINA que preocupa não faz quinquilharias (25/mai/07). Denise Neumann, Valor Econômico. Disponível em:

http://muitomaissite.com.br/abrameq/principal.php?idiomas id=1\&acao=noticia\&notic ias $i d=5332$. Acesso em: 01 jun., 2007.

ACORDO após quase uma década de tratativas (fev./03). Revista Tecnicouro, Centro Tecnológico do Couro, Calcados e Afins/Instituto Brasileiro de Couro, Calcado e Artefatos, Novo Hamburgo (RS). V. 23, n. 01, p. 59, fev-mar/2003.

ACORDO une Master e Matic (mai/04). Revista Tecnicouro, Centro Tecnológico do Couro, Calcados e Afins/Instituto Brasileiro de Couro, Calcado e Artefatos, Novo Hamburgo (RS). V. 25, n. 05, p. 18.

ALVES FILHO, Alceu Gomes (1991). Estratégia Tecnológica, Desempenho e mudança: estudos de caso em empresas da indústria de calçados. $189 \mathrm{p}$. Tese (doutorado). Engenharia de Produção, Escola Politécnica, Universidade de São Paulo (USP).

A ROTINA de compra, troca e manutenção de máquina (jan-fev/05). Revista Passarela, Franca. Ano 5, n. 18, p. 60, jan-fev/05.

ASSOCIAÇÃO BRASILEIRA DAS INDÚSTRIAS DE CALÇADOS (2005). Resenha Estatística 2005. Disponível em: <http://www.abicalcados.com.br/estatisticas.html.> Acesso em: 12 ago., 2007. 
<http://www.abicalcados.com.br/estatisticas.html>. Acesso em: 12 ago., 2007.

(2007a). Resenha Estatística 2007. Disponível em:

$\overline{<h t t p: / / w w w . a b i c a l c a d o s . c o m . b r / e s t a t i s t i c a s . h t m l .>~ A c e s s o ~ e m: ~} 12$ ago., 2007.

(2007b). Pólos produtores de Calçados. Disponível em:

http://www.abicalcados.com.br/polos-produtores.html. Acesso em: 10 set., 2007.

ASSOCIAÇÃO BRASILEIRA DAS INDÚSTRIAS DE MÁQUINAS PARA COURO, CALÇADOS E AFINS (2007). Máquinas do Brasil. Diretório de Máquinas Brasileiras para Calçados e Artefatos; Borracha, Plástico e Eva; Matrizes, Moldes, Navalhas e Formas; Tratamento de Efluentes; e Equipamentos para Laboratório. Novo Hamburgo (RS), 2007. 178 p.

ALEM, A. C. e PESSOA, R. M. (2005). "O setor de bens de capital e o desenvolvimento econômico: quais são os desafios?" BNDES Setorial, Rio de Janeiro. n. 22, p. 71-88. Setembro de 2005. Disponível em:

<http://www.bndes.gov.br/conhecimento/resposta.asp?setorTema=Bens+de+Capital $>$

AMBROS, J. O. (2000). A relação usuário-produtor em empresas da cadeia automobilística gaúcha. 2000, 97 p., Dissertação (Mestrado) - Escola de Administração, Universidade Federal do Rio Grande do Sul (UFRGS). Porto Alegre, 2000. Banco de teses e dissertações. Disponível em:

$<$ http://volpi.ea.ufrgs.br/teses_e_dissertacoes/detalheLivro.asp?livro=000371\&radioT ipo $=M>$

ANDRADE, J. E.; CORREA, A. R. (2001). Panorama da Indústria Mundial de Calçados com ênfase na América Latina. BNDES Setorial, Rio de Janeiro, n.13, p. 95-126. Março de 2001. Biblioteca Virtual de Inovação Tecnológica. Disponível em: $<$ http://www4.prossiga.br/finep/asp/SaidaCat.asp?cod=30\&id=port>

ATLAS SÓCIO ECONÔMIC O DO RIO GRANDE DO SUL (2007). Secretaria de Planejamento e Gestão (SEPLAG) do Estado do Rio Grande do Sul. Disponível em: <http://www.seplag.rs.gov.br/atlas/default.asp>. Acesso em: 21 out., 2007.

A UNIÃO faz a força (out/05). Martina Wartchow e Luciane Weber. RevistaMáquinas, Couros e Componentes: Grupo SINOS, Novo Hamburgo (RS). V. 02, n. 05, out-05, p. 16.

AVELLAR, A. P. (2004). Relatório Setorial: Bens de Capital. Rio de Janeiro: 
Financiadora de Estudos e Projetos (FINEP), Março de 2004. Relatório parcial Diretório de Pesquisa Privada (DPP). Portal DPP. Disponível em:

http://www.finep.gov.br/PortalDPP/relatorio setorial/impressao relatorio.asp?lst seto $\underline{\mathrm{r}=5}$. Acesso em: mar., 2005.

AZEVEDO, P. F. (2002). Competitividade da Cadeia de Couro e Calçados. Fórum de Competitividade da Cadeia Produtiva de Couro e Calçados. Programa de Estudos dos Negócios do Sistema Agroindustrial (PENSA).

Disponível em:

$<$ http://www.desenvolvimento.gov.br/arquivo/sdp/proAcao/forCompetitividade/anaCo mSetEstrategicas/estudopensaccouro.pdf.> Acesso em: 30 jan., 2004.

BATHELT, H.; MALMBERG, A.; MASKELL, P. (2003). Clusters and Knowledge: local buzz, global pipelines and the process of knowledge creation. Danish Research Unit for Industrial Dynamics (Druid), Working Paper, n.02-12. 2003. Disponível em: < http://www.druid.dk/wp/pdf files/02-12.pdf>. Acesso em: mai., 2003.

BELL, M. e ALBU, M. (1999). Knowledge Systems and Technological Dynamism in Industrial Clusters in Developing Countries. World Development, v. 27, n. 09, p. 1715-1734, 1999. Disponível em:

<http://www.sciencedirect.com/science/article/B6VC6-3X3BXDT-

D/2/a9be4a1 ebe125510c37fc8a6be2ac452>.

BELUSSI, F. e GOTTARDI, G. (2000). Models of localized technological change In: BELUSSI, Fiorenza. e GOTTARDI, Giorgio. "Evolutionary Patterns of Local Industrial Systems - towards a cognitive to the industrial district". Aldershot, England: Ashgate Publishing Ltd., cap. 1, p. 13-47, 2000.

BIELSCHOWSKY, R. (1999). Investimento na Indústria Brasileira depois da Abertura e do Real: o mini-ciclo de modernizações, 1995-97. Série Reformas Econômicas. Santiago do Chile: Cepal, n. 44, 1999. Disponível em: $<$ http://www.eclac.org/cgibin/getProd.asp?xml=/publicaciones/xml/6/4566/P4566.xml\&xsl=/brasil/tpl/p9f.xsl\&ba se=/brasil/tpl/top-bottom.xsl>

BRASIL CONTRA-ATACA e vai à Ásia vender sapatos (26/set/07). Valor Econômico. Disponível em: <http://www.abrameq.com.br/>. Acesso em: 26 set., 2007.

BRASIL MOSTRA na Colômbia tecnologia em máquinas para couros e calçados (03/ago/07) Assessoria de imprensa ABRAMEQ. Disponível em: http://www.global21.com.br/materias/materia.asp?tipo=noticia\&cod=16361. Acesso em: 10 set., 2007. 
BRASIL SURPREENDE lojistas europeus com calçados de alto padrão na Micam (27/set/05). Abicalçados. Notícias. Disponível em:

$<$ http://www.global21.com.br/materias/materia. asp?tipo=noticia\&cod=8900 $>$. Acesso em: 11 de abr., 2006.

BRESCHI, S. e LISSONI, F. (2001). Knowledge Spillovers and Local Innovation Systems: A Critical Survey. Industrial and Corporate Change, v. 10, n. 4, p. 9751005, 2001.

BRESCHI, S. e MALERBA, F. (2001). The Geography of Innovation and Economic Clustering: some Introductory Notes. Industrial and Corporate Change, v. 10, n. 4, p. 817-833, 2001.

BRITO, J. (2004). "Cooperação e aprendizado em arranjos produtivos locais: em busca de um referencial analítico". In: CASSIOLATO, José Eduardo e LASTRES, Helena Maria M. (coord). Aprendizado, Capacitação e Cooperação em Arranjos Produtivos e Inovativos Locais de MPEs: implicações para políticas. Nota Técnica 04, Instituto de Economia, Universidade Federal do Rio de Janeiro.

BUTTENBENDER, P. L. (2002). Acumulação de Competências Tecnológicas e os Processos Subjacentes de Aprendizagem na Indústria Metal-Mecânica: 0 Caso de AGCO - Indústria de Colheitadeiras. In: Encontro de Estudos Organizacionais, 2002, Recife. Anais... Recife: Observatório da Realidade Organizacional: PROPAD/UFPE : ANPAD, 2002. 1 CD. Disponível em: $<$ http://www.anpad.org.br/eneo/2002/dwn/eneo2002-32.pdss

CAFÉ, S. L.; NASSIF, A.; SOUZA, P. Z.; SANTOS, B. G. (2004). Notas preliminares sobre o desempenho competitivo da indústria de bens de capital brasileira no período recente. BNDES Setorial, Rio de Janeiro, n. 20, p. 223-252, setembro de 2004. Estudos e Publicações, BNDES. Disponível em:

http://www.bndes.gov.br/conhecimento/resposta.asp?setorTema=Bens+de+Capital

CALÇADO brasileiro já chega a 135 países (18/set/03). Nathalia Barbosa. Caderno Dinheiro, Folha de São Paulo (online). Disponível em:

<http://www1.folha.uol.com.br/folha/dinheiro/ult91u73836.shtml>. Acesso em: 20 nov., 2004.

CÂMBIO E ESCALAS explicam vantagem chinesa (14/dez/05). Valor Econômico.

Disponível em:

http://www.global21.com.br/materias/materia.asp?tipo=noticia\&cod=9739.

Acesso em: 11 abr., 2006. 
CÂMBIO PREJUDICA exportações de máquinas (10/abr/2006). ABRAMEQ. Disponível em: <http://www.abrameq.com.br/> Acesso em: 11 abr., 2006.

CAMPOS, R. R.; CARIO, S. A. F..; NICOLAU, J. A; VARGAS, G. (2003) Aprendizagem por interação: pequenas empresas em sistemas produtivos $\mathrm{e}$ inovativos locais. In: LASTRES, H.M.M, CASSIOLATO, E., MACIEL, M.L., (orgs) Pequena empresa: cooperação e desenvolvimento local, Rio de Janeiro: Relume Dumará: Instituto de Economia, Universidade Federal do Rio de Janeiro. Cap. 3, p. 51-65.

CASSIOLATO, J. E. (1992). The user-producer connection in high tech. A case-study of banking automation in Brazil. In: Schmitz, H. e Cassiolato, J. E.Hi-Tech for Industry Development. Lessons from the Brazilian experience in eletronics and automation. Institute of Development Studies. University os Sussex. Cap. 3, p. 53-89.

CASSIOLATO, J. E. e LASTRES, H.M.M. (2001). Arranjos e Sistemas Produtivos Locais na Indústria Brasileira. Revista Economia Contemporânea. V. 5, Especial. Disponível em:

$<$ http://www.ie.ufrj.br/revista/pdfs/arranjos e sistemas produtivos locais na industri a brasileira.pdf>. Acesso em: mai., 2004.

CASSIOLATO, J. E. (2004). Integração, aprendizado e cooperação tecnológica" Instituto de Economia, Universidade Federal do Rio de Janeiro. Texto preparado para a Red Iberoamericana de Indicadores de Ciência Y Tecnologia (RIC YT). Julho de 2004. Disponível em:

$<$ http://www.ricyt.edu.ar/interior/subredes\%5Cinnova\%5Cdocs/Cassiolato.pdf > . Acesso em> 05 mai., 2006.

CATÁLOGO DE EXPORTADORES BRASILEIROS (2006). Confederação Nacional das Indústrias (CNI). Disponível em: http://www.brazil4export.com/. Acesso em: abr., 2006.

CHINESES vêm para tomar os mercados, inclusive o Brasil (07/abr/06). Jornal Novo Hamburgo (RS). Disponível em:

$<$ http://www.global21.com.br/materias/materia. asp?tipo=noticia\&cod $=10880>$.

Acesso em: 11 abr., 2006.

COHEN, W. M. e LEVINTHAL, D. A (1990). Absorptive Capacity: New Perspective on Learning and Innovation. Administrative Science Quarterly, v. 35, p. 128-152, 1990. 
COMPRADORES internacionais impressionados com máquinas brasileiras (06/abr/06). CTCCA. Notícias. Disponível em:

http://ctcca.locaweb.com.br/index.php?idiomas id=1\&acao=noticias\&noticias $i d=711$

. Acesso em: 13 abr., 2006.

CONCORRÊNCIA CHINESA prejudica vendas brasileiras no México (23/fev/06)

Abrameq. Disponível em:

$<$ http://www.global21.com.br/materias/materia.asp?tipo=noticia\&cod=10466 $>$.

Acesso em: 11 abr., 2006.

CONCORRÊNCIA FAZ grande empresa ir à China para produzir (12/mar/07). DCl.

Disponível em:

$<$ ttp://www.abrameq.muitomaissite.com.br/principal.php?idiomas_id=1\&acao=noticia s\&noticias_id=4873>.

CONSULTOR italiano conhece o setor de máquina brasileiro para prospectar clientes internacionais (19/jan/2004). Revista Passarela online. Disponível em: <http:www.revistapassarela.com/15.html>. Acesso em: 24 mai., 2004.

CORREA, A. R. (2001). O complexo coureiro-calçadista brasileiro. BNDES Setorial, Rio de Janeiro, n. 14, p. 85-92, Setembro de 2001. Biblioteca Virtual de Inovação Tecnológica. Disponível em:

<http://www4.prossiga.br/finep/asp/SaidaCat.asp?cod=30\&id=port>

COSTA, A. B. (1993). Modernização e Competitividade da Indústria de Calçados Brasileira. 1993, 275 p, Tese (Doutorado) - Faculdade de Ciências Econômicas. Universidade Federal do Rio Grande do Sul, Rio Grande do Sul, 1993.

(2002). Estudo da Competitividade de Cadeias integradas no Brasil:

impactos das áreas de livre comércio. Cadeia: Couro e Calçados. Nota Técnica Final. Ministério do Desenvolvimento, da Indústria e do Comércio (MDIC), Outubro de 2002. Núcleo de Economia Industrial e da Tecnologia (NEIT), Pesquisas.

Disponível em: <http://www.eco.unicamp.br/neit/estudo_compet.htm>

CROCCO, M.; S., SIMÕES, R.; HORÁCIO, F. (2000). Industrialização descentralizada: Sistemas Industriais Locais - O Arranjo Produtivo Calçadista de Nova Serrana. Nota Técnica 36 - Estudos Empíricos in: Arranjos e Sistemas Produtivos Locais e as Novas Políticas de Desenvolvimento Industrial e Tecnológico. Instituto de Economia, Universidade Federal do Rio de Janeiro, Contrato BNDES/FINEP/FUJB.

CTCCA (2002). Estruturação Fabril: Modelagem e Fabricação de Calçados. Série 
Literatura Técnica Básica em Calçados. V. 3. Centro Tecnológico do Couro, Calçados e Afins (CTCCA), Novo Hamburgo (RS), Maio de 2002.

DIEHL, A. L. (2005). Mudanças de layout para melhoria de produtividade no setor de costura em uma indústria calçadista. 2005. Dissertação (Mestrado) Mestrado profissionalizante em Engenharia, Universidade Federal do Rio Grande do Sul (UFRGS). Porto Alegre (RS).

DUARTE, A. (2001). O Desempenho do setor de Bens de Capital no Brasil nos anos 90: Os impactos da Política Econômica e as implicações para o desenvolvimento. 2001, 160 p, Tese (Doutorado) - Instituto de Economia, Universidade Federal do Rio de Janeiro. Rio de Janeiro (RJ).

EDQUIST, C. e HOMMEN, L. (1999). Systems of innovation: theory and policy for the demand side. Technology in Society, v. 21, n. 1, p. 63-79, 1999.

EMPRESAS de grandes volumes buscam alternativas para exportar (25/set/07) Assessoria de Imprensa Abicalçados. Disponível em:

http://www.global21.com.br/materias/materia.asp?tipo=noticia\&cod=16991.

Disponível em: 10 out., 2007.

ERBER, F. S., VERMULM, R. (2002). Cadeia bens de capital - estudo da competitividade de cadeias integradas no Brasil: impactos das zonas de livrecomércio. Campinas: Unicamp, MDIC e outros. Disponível em:

$<$ http://www.eco.unicamp.br/Neit/cadeias_integradas/NT_FINAL_Bens_de_Capital.p df>

ESCOLA POLITÉCNICA DA USP (2006). São Paulo. Diretrizes para apresentação de dissertações e teses. Disponível em:

$<$ http://www.poli.usp.br/Bibliotecas/PublicacoesOnLine/Diretrizes3.pdf >. Acesso em: 14 mar., 2007.

ETIÓPIA é mais um alvo (ago/2005). Lançamentos - Máquinas, Couros e Componentes: Grupo SINOS, Novo Hamburgo (RS). V. 02, n. 04, Ago-05, p. 24-25.

EVOLUÇÃO das máquinas está baseada em pesquisas informais (abr/93). Revista Tecnicouro, Centro Tecnológico do Couro, Calcados e Afins/Instituto Brasileiro de Couro, Calcado e Artefatos, Novo Hamburgo (RS). Matéria especial, v. 14, n. 3, p. 14-20. 
(mar-abr/2004). ABRAMEQ. In: Revista Couro business. N. 33.

EXPORTAÇÕES BRASILEIRAS DE MÁQUINAS CRESCEM 60\% em um ano (13/abr/05). CTCCA. Disponível em:

$<$ http://ctcca.locaweb.com.br/index.php?idiomas_id=1\&acao=noticias\&noticias_id =50 3>. Acesso em: 15 nov., 2005.

FABRICANTES DE MÁQUINAS BUSCAM espaço na Índia, Colômbia e México (26/jan/06). Abrameq. Disponível em:

$<h$ ttp://www.global21.com.br/materias/materia. asp?tipo=noticia\&cod=10155 $>$.

Acesso em: 11 abr., 2006.

FABRICANTES DE MÁQUINAS COMPRARÃO em conjunto para enfrentar a crise (31/mai/07). Assessoria de Comunicação Abrameq. Disponível em:

http://www.global21.com.br/materias/materia.asp?tipo=noticia\&cod=15545.

Disponível em: 10 out., 2007.

FABRICANTES DISCUTEM segurança na indústria (14/out/04). Caderno Economia, Jornal do Comércio, Porto Alegre. p. 11.

FATORES de transferência de tecnologia das máquinas (set-out/05). Revista Passarela, Franca. Ano 5, n. 22, p. 8, set-out/05.

FIGUEIREDO, P. N. (2000). "Trajetórias de acumulação de competências tecnológicas e os processos subjacentes de aprendizagem: revisando estudos empíricos". Revista de Administração Pública (RAP), Rio de Janeiro, v. 34, n. 1, p. 7 33, Jan-Fev/2000. Disponível em:

$<$ http://www.ebape.fgv.br/academico/asp/dsp_rap_edicoes_passadas.asp>

FILHO, B. S. da S. (2006). Controladores Lógicos Programáveis. Rio de Janeiro: Faculdade de Engenharia - Universidade do Estado do Rio de Janeiro (UERS), 2006. 37 p., Apostila do Curso de CLP. Laboratório de Engenharia Elétrica. Disponível em: < http://www.lee.eng.ueri.br>. Acesso em: 01 out., 2007.

FLEURY, A.; FLEURY, M. T. L. (1995). Aprendizagem e Inovação Organizacional: as experiências de Japão, Coréia e Brasil. São Paulo: Editora Atlas S.A.

FREEMAN, C. (1988). Japan: a New National System of Innovation? In: Dosi, G. et al. Technical Change and Economy Theory. London: Pinter Publishers-Cap. 16, p. 330-348. 
(1995). The National System of Innovation in historical perspective.

Cambridge Journal of Economics, v. 19, p. 5-24, 1995.

GARCIA, R. (2001). Vantagens Competitivas das empresas em aglomerações industriais: Um estudo aplicado à indústria brasileira de calçados e sua inserção nas cadeias produtivas globais. 2001. 182 p. Tese (Doutorado) Instituto de Economia, Universidade Estadual de Campinas. Campinas (SP), 2001.

(2005). Relatório Setorial: Calçados. Rio de Janeiro: Financiadora de Estudos e Projetos (FINEP) 2005. Relatório final - Diretório de Pesquisa Privada (DPP). Disponível em:

www.finep.gov.br/PortalDPP/relatorio setorial final/relatorio setorial final impressa o.asp?lst setor $=30-152 \mathrm{k}$. Acesso em: 05 dez., 2006.

. (2006). Economias Externas e Vantagens Competitivas dos Produtores em Sistemas Locais de Produção: as visões de Marshall, Krugman e Porter. Revista Ensaios FEE, Porto Alegre, v.27, n. 2, 2006.

GARCIA, R.; MOTTA, F. G.; AMATO NETO, J. (2004). Uma análise das características da estrutura de governança em Sistemas Locais de Produção e suas relações com a cadeia global. Revista Gestão e Produção, v. 11, n. 3, p. 343-354, Set-dez/2004.

GAZETA MERCANTIL (2000a). O mercado de calçados. In: Panorama Setorial Gazeta Mercantil. V. 1, p. 78-83, Julho de 2000.

GAZETA MERCANTIL (2000b) O mercado de calçados. In: Panorama Setorial Gazeta Mercantil. V. 2, p. 74-96, Julho de 2000.

GEREFFI, G. (1994). The Organization of Buyer-Driven Global Commodity Chains: How U.S. Retailers Shape Overseas Production Networks. In: Gereffi, Gary e Korzeniewicz, Miguel (Orgs.). Commodity Chains and Global Capitalism. Westport, Greenwood Publishing Group, 1994.

GOMES, R. L.; TRISTÃO, H. M.; ALMEIDA, F. C. de (2003). As alianças como estratégia para a competitividade internacional: um exemplo em desenvolvimento no setor de máquinas para costura de calçados. II Congresso do Instituto FrancoBrasileiro de Administração de Empresas (IFBAE), 23-27/maio/2003. Faculdade de Ciências Econômicas, Administrativas e Contábeis de Franca (FACEF), Franca, São Paulo, 2003. (CD-ROM) 
GORINI, A. P. Fontenelle; SIQUEIRA, Sandra Helena Gomes (1999a). Complexo Coureiro-calçadista. BNDES Setorial, Rio de Janeiro, n. 9, 40 p. Biblioteca Virtual de Inovação Tecnológica. Disponível em:

<http://www4.prossiga.br/finep/asp/SaidaCat.asp?cod=30\&id=port>

GORINI, A. P. F.; SIQUEIRA, S. H. G. (1999b). Complexo Coureiro-Calçadista Nacional: uma avaliação do programa de apoio do BNDES. BNDES Setorial, Rio de Janeiro, n. 9. , 40 p. Biblioteca Virtual de Inovação Tecnológica. Disponível em: $<$ http://www4.prossiga.br/finep/asp/SaidaCat.asp?cod=30\&id=port>

GORINI, A. P.; CORREA, A. R.; SILVA, C. V. D. G. F. (2000). A indústria calçadista de Franca. Área de Operações Industriais. BNDES, Relatos Setoriais, Rio de Janeiro, Disponível em:

<http://www.bndes.gov.br/conhecimento/resposta.asp?setorTema=Cal\%E7ados>

GRANOVETTER, M. (1985). Economic Action and Social Structure: the problem of embeddednes. American Journal of Sociology, v. 91, n. 3, p. 481-510, November de 1985.

HELLER, C. (2006). Path-dependence, Lock-in e Inertia. In: PELAEZ, Victor e SZMRECSANY (2006). Economia da Inovação Tecnológica. Editora Hucitec, São Paulo. Capítulo 11, p. 260-284.

INDÚSTRIA brasileira já exporta $27 \%$ de tudo que produz (13/jul/06). Valor Econômico. Disponível em:

<http://www.global21.com.br/materias/materia.asp?tipo=noticia\&cod=11962>

INDÚSTRIA DE MÁQUINAS atrai parceiros internacionais (20/mai/00). Gazeta Mercantil RS.

INSTITUTO BRASILEIRO DE GEOGRAFIA E ESTATÍSTICA (2007a). Anuário Estatístico do Setor Industrial. Departamento de Contas Nacionais. Disponível em: $<$ http://www.desenvolvimento.gov.br/sitio/publicacoes/desProducao/anu Estatistico.p hp>. Acesso em: 11 set., 2007.

(2007b). Pesquisa de Inovação Tecnológica - PINTEC - 2005. Estatísticas. Disponível em: http://www.ibge.gov.br/home/estatistica/economia/industria/pintec/2005/manual2005. pdf. Acesso em: 30 ago., 2007. 
INVASÃO de equipamentos chineses assusta indústria (18/jan/2006) Valor Econômico, Disponível em:

$<$ http://www.global21.com.br/materias $/$ materia. asp?tipo=noticia\&cod $=10033>$.

Acesso em: 11 abr., 2006.

INVESTIMENTOS da indústria de máquinas e equipamentos totalizaram $\mathrm{R} \$ 6,9$ bilhões (01/mar/2007). Empresas e Negócios. Revista Fator. Disponível em: <http://www.revistafatorbrasil.com.br/ver_noticia.php?not=5741>. Acesso em: 11 abr., 2007.

JUNIOR, José Antônio Valle Antunes; RUAS, Roberto (1992). Competitividade e Estratégias de Gestão em Indústrias Tradicionais: processos e limites recentes. Ensaios Fundação de Economia e Estatística (FEE), Porto Alegre, v. 13, n. 1, p. 204225, 1992.

KUPFER, D. (1998). Trajetórias de reestruturação da indústria brasileira após a abertura e estabilização. 1998. 197 p. Tese (Doutorado) - Instituto de Economia, Universidade Federal do Rio de Janeiro. Rio de Janeiro.

LAPLANE, M., SARTI, F. (1997). Investimento Direto Estrangeiro e a Retomada do Crescimento Sustentado nos Anos 90. Revista Economia e Sociedade, Campinas, v. 8, p.143-181, junho de 1997.

LEMOS, C. (2000). Inovação na Era do Conhecimento. Revista Parcerias Estratégias, Brasília, v. 01, n. 08, p. 157-180. Maio de 2000. Disponível em: < http://www.cgee.org.br/parcerias/p08.php>.

LEMOS, C. e PALHANO, A. (2000). Arranjo Produtivo Coureiro-Calçadista de Campina Grande/PB. Nota Técnica 22 - Estudos Empíricos in: Arranjos e Sistemas Produtivos Locais e as Novas Políticas de Desenvolvimento Industrial e Tecnológico. Relatório Final. Instituto de Economia/Universidade Federal do Rio de Janeiro, Contrato BNDES/FINEP/FUJB. Dez/2000.

Biblioteca Virtual de Inovação Tecnológica. Disponível em: <http://www4.prossiga.br/finep/asp/SaidaCat.asp?cod=30\&id=port>

LIVRE flutuação é lubrificante para o setor (mar/1999). Revista Tecnicouro, Centro Tecnológico do Couro, Calcados e Afins/Instituto Brasileiro de Couro, Calcado e Artefatos, Novo Hamburgo (RS). V. 20, n. 2, p. 18-21.

LUNDVALL, Bengt-Ake (1988). Innovation as an interactive process: from userproducer interaction to the national systems of innovation. In: Dosi, G. et al. Technical Change and Economy Theory. London: Pinter Publishers. p. 349-369, 
1988.

(1992). User Producer Relationships, National Systems of Innovation and Internationalization. In: National Systems of Innovation: Towards a theory of innovation and interactive learning. Cap. 3, p. 45-67.

MALERBA, F. (1992). Learning by Firms and Incremental Technical Change. The Economic Journal. v. 102, n. 413, p. 845-859.

MALERBA, F.; ORSENIGO, L. (1997). "Technological Regimes and Sectoral Patterns of Innovative Activities". In: The Evolution of Industrial Structures. Industrial and Corporate Change. V. 6, ํo 01, p. 83-117. Oxford University Press.

MALERBA, F. (2002) Sectoral Systems and Innovation and Technology Policy. In: Revista Brasileira de Inovação, v. 2, n. 02, p. 329-375, Julho-Dezembro/2002.

MÁQUINAS brasileiras na Colômbia e México (01/fev/2007). Apex-Brasil. Disponível em:

http://www.g21.com.br/materias/materia.asp?tipo=noticia\&cod=14168\&print=true. Acesso em: 13 jul., 2007.

MARRONE, P. (2006). China e seus efeitos sobre a indústria de máquinas e equipamentos do Brasil. São Paulo: ABIMAQ, 2006, 159 p.

MARSHALL, A. (1920) Organização Industrial. In: Princípios de Economia. Rio de Janeiro: Epasa, Cap. VIII a X, p. 229-260, 1946.

MASKELL, P. (2001). Towards a Knowledge-based Theory of the Geographical Cluster. Industrial and Corporate Change, v. 10, n. 4, p. 921-943, 2001.

MERCADO externo sustenta a venda de máquinas nacionais (09/fev/07). DCl. Disponível em:

$<$ http://www.abrameq.muitomaissite.com.br/principal.php?idiomas id=1\&acao=notici as\&noticias id=4714.> Acesso em: 15 mai., 2007.

MICAM aponta um novo caminho para o calçado brasileiro (21/set/07). Assessoria de Comunicação Abicalçados. Disponível em:

http://www.global21.com.br/materias/materia.asp?cod=16948\&tipo=noticia . Acesso em: 10 out., 2007. 
MINISTÉRIO DO DESENVOLVIMENTO DA INDÚSTRIA E DO COMÉRCIO EXTERIOR (2001). Fórum de Competitividade da Cadeia Produtiva de Couro e Calçados. Diagnóstico, 09/10/2001. Disponível em:

<http://www.desenvolvimento.gov.br/arquivo/sdp/proAcao/forCompetitividade/doclnst alacoes/sumarioexecccouro.pdf>

(2002). Fórum de Competitividade da Cadeia Produtiva de Couro e

Calçados. Relatório de Resultados, 19/dez/2002.

Disponível em:

<http://www.desenvolvimento.gov.br/arquivo/sdp/proAcao/forCompetitividade/doclnst alacoes/resCouCalcados191202.pdf>

MODELAGEM manual e informatizada (mar-abr/05). Revista Passarela, Franca. Ano 5, n. 19, p. 14, mar-abr/05.

MOTTA, F. G. (2006). Sistemas locais de produção e cadeias produtivas globais: estudo das diversas formas de inserção da indústria de móveis nos mercados e os impactos nas estruturas produtivas locais. $235 \mathrm{p}$. Tese (doutorado) - Engenharia de Produção, Escola Politécnica, Universidade de São Paulo (USP). São Paulo (SP), 2006.

MUSCAT, A. R. N. e FLEURY, A. C. C. (1992) Indicadores da Qualidade e Produtividade na Indústria Brasileira. In: Revista Indicadora da Qualidade e Produtividade. Artigo IV, p. 82-107.

NELSON, R.; WINTER, S. (1982). An evolutionary theory of economic change. Cambridge: Harvard University Press.

NONAKA, I.; TAKEUCHI, H. (1997). Criação de conhecimento na empresa : como as empresas japonesas geram a dinâmica da inovação. Rio de Janeiro : Elsevier: Campus. 14ª edição.

NORONHA, E. G.; TURCHI, L. M. (2002). Cooperação e Conflito: Estudo de caso do complexo coureiro-calçadista no Brasil. Texto para discussão 861, Instituto de Pesquisa Econômica Aplicada (IPEA), Março de 2002. Biblioteca Virtual de Inovação Tecnológica. Disponível em:

<http://www4.prossiga.br/finep/asp/SaidaCat.asp?cod=30\&id=port>

NOVAS tecnologias geram incremento dos negócios (Fev/03). Revista Tecnicouro, Centro Tecnológico do Couro, Calcados e Afins/Instituto Brasileiro de Couro, Calcado e Artefatos, Novo Hamburgo (RS). V. 23, n. 1, p. 60. 
PASSOS, M. C. (1998). "Competitividade e Inovação na Indústria Gaúcha: o setor de máquinas-ferramentas s no Rio Grande do Sul”. Núcleo de Estudos Industriais, Fundação de Economia e Estatística (FEE) Siegfried Emanuel Heuser, Porto Alegre.

PARCEIRAS de sucesso (out/2005). Martina Wartchow. Revista Lançamentos Máquinas, Couros e Componentes: Grupo SINOS, Novo Hamburgo (RS). V. 02, n. 05, out-05, p. 18-19.

PAVITT, K. (1984). "Sectoral Patterns of Technical Change: towards a taxonomy and theory". Science Policy Research Unit, University of Sussex, Bringhton. v. 13, p. 343373, 1984.

PLANEJAR a manutenção (nov-dez/05). Revista Passarela, Franca. Ano 5, n. 23, p. 24-29, nov-dez/05.

PORTER, M. E. (1993a). "A necessidade de um novo paradigma". In: PORTER (1993). Vantagem Competitiva. Rio de Janeiro: Campus. Waltensir Dutra (trad.) Cap. 1 p. $1-40$.

(1993b). "Determinante da Vantagem Competitiva Nacional". In: PORTER (1993). Vantagem Competitiva. Rio de Janeiro: Campus. Waltensir Dutra (trad.) Cap. 3 p. 85-159.

(1993c). "A dinâmica da Vantagem Competitiva Nacional”. In: PORTER (1993). Vantagem Competitiva. Rio de Janeiro: Campus. Waltensir Dutra (trad.) Cap. 4 p. 161-212.

PREFEITURA MUNICIPAL DE FRANCA (2007). Mapa. Disponível em: http://www.franca.sp.gov.br/index2.htm. Acesso em: 23 out., 2007.

QUEIROZ, S. (2006). Aprendizado tecnológico. In: PELAEZ, Victor e SZMRECSANY (2006). Economia da Inovação Tecnológica. Editora Hucitec, São Paulo. Capítulo 8, p. 193-211.

REICHERT, C. L. (2004). A evolução tecnológica da indústria calçadista no sul do Brasil. In: COSTA, Achyles Barcelos; PASSOS, Maria Cristina (2004). A indústria calçadista no Rio Grande do Sul. Editora Unisinos. São Leopoldo (RS). Capítulo 3, p. 51-68. 
RESENDE, M. F. C. e ANDERSON, P. (1999). Mudanças estruturais na industria brasileira de bens de capital. Texto para discussão n. 658. Instituto de Pesquisas Econômicas Aplicadas (IPEA), Brasília, Julho de 1999. Disponível em:

$<$ http://www.ipea.gov.br/pub/td/td.html>

RESENDE, M. F. C. e TEIXEIRA, J. R. (2001). Competitividade, Vulnerabilidade Externa e Crescimento na Economia Brasileira: 1978-2000. Texto para discussão n. 844. Instituto de Pesquisas Econômicas Aplicadas (IPEA), Brasília, Julho de 1999. Disponível em: <http://www.ipea.gov.br/pub/td/td.html>

ROVERE, R. L. (2006). Paradigmas e Trajetórias Tecnológicas. In: PELAEZ, Victor e SZMRECSANY (2006). Economia da Inovação Tecnológica. Editora Hucitec, São Paulo. Capítulo 12, p. 285-301.

ROTINA CAD/CAM (jul-ago/05). Revista Passarela, Franca. Ano 5, n. 21, p. 38, julago/05.

RUFFONI, J. (2004). A indústria de máquinas para calçados e curtumes no Rio Grande do Sul. In: COSTA, Achyles Barcelos; PASSOS, Maria Cristina (2004). A indústria calçadista no Rio Grande do Sul. Editora Unisinos. São Leopoldo (RS). Capítulo 4, p. 69-86.

SCHMITZ, H. (1998). Responding to global competitive pressure: local co-operation and upgrading in the Sinos Valley, Brazil. Institute of Development Studies (IDS), Working Paper, n. 82, 1998.

SCHUMPETER, J. A. (1942). Capitalismo, Socialismo e Democracia. Rio de Janeiro: Zahar, 1984.

SCUR, G. (2006). Geração e difusão de conhecimento em sistemas locais de produção. 250 p. Tese (Doutorado) - Engenharia de Produção, Escola Politécnica, Universidade de São Paulo (USP). São Paulo (SP), 2006.

SEGUNDO maior produtor de calçados do mundo quer o Brasil como parceiro (15/fev/06). Assessoria de Imprensa/Assintecal. Notícia. Disponível em: $<$ http://www.global21.com.br/materias/materia. asp?tipo=noticia\&cod=10372>. Acesso em: 11 abr., 06.

SETOR DE MÁQUINAS INVESTE para conter China (27/fev/07). Folha de São Paulo, São Paulo, 27 de fevereiro de 2007. Caderno Dinheiro. Disponível em: 
$<$ http://www1.folha.uol.com.br/folha/dinheiro/ult91u114695.shtml>. Acesso em: 01 abr., 2007.

SETOR DE MÁQUINAS MOVIMENTA R \$ 50 bilhões (09/out/06) ANBA. Disponível em: <http://www.global21.com.br/materias/materia.asp?tipo=noticia\&cod=12965>. Acesso em : 11 abr., 2007.

SETOR DE MÁQUINAS SUPERA expectativas no exterior. Revista Tecnicouro. Centro Tecnológico do Couro, Calcados e Afins/Instituto Brasileiro de Couro, Calcado e Artefatos, Novo Hamburgo (RS). V. 20, n. 8. set-Out/1999, p. 11.

SILVA, A. de O. (2003). A inovação tecnológica nos arranjos produtivos locais: uma análise do papel e das funções da indústria de bens de capital para couro e calçados no período recente. 2003. 73 p. Monografia - Departamento de Economia, Faculdade de Ciências e Letras, Universidade Estadual Paulista Júlio de Mesquita Filho. Araraquara (SP), 2003.

SOUZA, S. D. C.; ARICA, J. (2006). "Uma análise comparativa entre sistemas de inovação e o diamante de Porter na abordagem de arranjos produtivos locais". Revista Produção, v. 16, n. 01, p. 80-87, Jan-Abr/2006. Disponível em: <http://www.scielo.br/cgi-bin/wxis.exe/iah/>

SUZIGAN, W. (2000). Aglomerações industriais como focos de políticas. In: Revista de Economia Política, v. 21, n. 3, 2001. Disponível em:

$<$ http://www.rep.org.br/conteudo.asp>

SUZIGAN, W.; FURTADO, J.; GARCIA, R. ; SAMPAIO, S. E. K. (2002). Clusters ou Sistemas Locais de produção e inovação: identificação, caracterização e medidas de apoio. Nova Política Industrial, Instituto de Estudos para o Desenvolvimento Industrial (IEDI), n. 12 - Maio/Junho de 2002.

(2003a) Sistemas Locais de Produção: mapeamento, tipologia e sugestões de política. Texto apresentado no XXXI Encontro Nacional de Economia - Porto Seguro, BA, 9 a 12 de dezembro de 2003. Disponível em:

<http://geein.fclar.unesp.br/atividades/pesquisacluster/new/sistemaslocaisdeproduca omtsp.pdf>

(2003b). "Governança dos sistemas produtivos locais de micro, pequenas e médias empresas". In: LASTRES, H.M.M, CASSIOLATO, E., MACIEL, M.L., (orgs). Pequena empresa: cooperação e desenvolvimento local, Rio de Janeiro: Relume Dumará: Instituto de Economia, Universidade Federal do Rio de Janeiro. Cap. 4, p. 67-84. 
(2004). A dimensão regional das atividades de C\&T no Estado de São

Paulo. Indicadores de Ciência, Tecnologia e Inovação em São Paulo - Fapesp, Cap. 9.

(2006). Identificação, mapeamento e caracterização estrutural de arranjos produtivos locais no Brasil. Relatório Consolidado. Diretoria de Estudos Setoriais (DISET) - Instituto de Pesquisa Econômica Aplicada (IPEA), Out/2006. Disponível em:

$<$ http://www.ipea.gov.br/sites/000/2/estudospesq/apls/Relat final IPEA28fev07.pdf>. Acesso em: 25 fev., 2007.

TACLA, C. L. (2002). Acumulação de competências tecnológicas e os processos subjacentes de aprendizagem na indústria de bens de capital: 0 caso da Kvaerner Pulping no Brasil. Dissertação (mestrado). Escola Brasileira de Administração Pública, Universidade Federal do Rio de Janeiro. Rio de Janeiro. Dissertações e Teses, Disponível em: http://www.ebape.fgv.br/academico/asp/dsp_dit_resumos.asp?cd_artigo=579

TACLA, C. L. e FIGUEIREDO, P. N. (2002). Aprendizagem e Competências tecnológicas na Indústria de Bens de Capital: o caso da Kvaerner Pulping do Brasil. XXII Simpósio de Gestão da Inovação Tecnológica, Salvado (BA), 6-8 de novembro de 2002. Disponível em:

$<$ http://intranet.planejamento.fiocruz.br/relatorios/simposio/doc acrobat\%5C2297884 8.pdf.>

TATSCH, A. L. (1995) Os impactos das novas tecnologias sobre o processo de trabalho: Um estudo de caso da indústria produtora de bens de capital para o setor coureiro- calçadista. 1995. 153 p. Tese (Doutorado) - Faculdade de Ciências Econômicas, Universidade Federal do Rio Grande do Sul (UFRGS). Porto Alegre (RS), 1995.

TECNOLOGIA em máquinas estáticas e CAD/CAM (set-out/99). Revista Tecnicouro, Centro Tecnológico do Couro, Calcados e Afins/Instituto Brasileiro de Couro, Calcado e Artefatos, Novo Hamburgo (RS). V. 20, n. 08, p. 18.

TECNOLOGIA para componentes injetados (set-out/99). Revista Tecnicouro, Centro Tecnológico do Couro, Calcados e Afins/Instituto Brasileiro de Couro, Calcado e Artefatos, Novo Hamburgo (RS). V. 20, n. 08, p. 16-18.

TECNOLOGIA em máquina de montar bico (jul/02). Informativo Técnico. Revista Tecnicouro, Centro Tecnológico do Couro, Calcados e Afins/Instituto Brasileiro de Couro, Calcado e Artefatos, Novo Hamburgo (RS). V. 23, n. 02, p. 42-44. 
TEECE, D.; PISANO, G. (1994). "The Dynamic Capabilities of Firms: an Introduction". Industrial and Corporate Change, Oxford University Press, v. 03, n. 03, p. 537-556.

TIGRE, P. B.; PIO, M. J. (2007). Setor de calçados: Competitividade, Mudança Tecnológica e Organizacional. Série Estudos Setoriais. Modelo SENAI de Prospecção.

TIRONI, L. F. (2000). Os Desafios e Oportunidades da Indústria Brasileira: o Associativismo Competitivo. Disponível em: < http://www.desenvolvimento.gov.br/ arquivo/sti/publicações /futAmaDilOportunidades/futIndustria_10.pdf>.Acesso em: 30 ago., 2004.

US\$ 5 MILHÕES em negócios projetados na ANPIC (mar/04). Revista Tecnicouro, Centro Tecnológico do Couro, Calcados e Afins/Instituto Brasileiro de Couro, Calcado e Artefatos, Novo Hamburgo (RS). V. 25, n. 01, p. 66.

VARGAS, M. A. e ALIEVI, R. M. (2000). "Arranjo Produtivo Coureiro-Calçadista do Vale do Sinos/ RS". Nota Técnica 21 - Estudos Empíricos. In: Arranjos e Sistemas Produtivos Locais e as Novas Políticas de Desenvolvimento Industrial e Tecnológico. Instituto de Economia/Universidade Federal do Rio de Janeiro, Contrato BNDES/FINEP/FUJB. Biblioteca Virtual de Inovação Tecnológica. Disponível em: <http://www4.prossiga.br/finep/asp/SaidaCat.asp?cod=30\&id=port>

VERMULM, R. (1996). Estratégias empresariais nos anos 80: o setor de máquinasferramenta. Caderno de Gestão Tecnológica nํ30, Núcleo de Política e Gestão Tecnológica (PGT/USP) Disponível em: <http://www.fundacaofia.com.br/pgtusp/publicacoes/arquivos cyted/Cad30.PDF.>

VERMULM, R. (2003). A indústria de bens de capital seriados. Comissão Econômica para a América Latina e o Caribe (CEPAL) - escritório no Brasil. Documento elaborado no âmbito do Convênio CEPAL- IPEA, Dez-2003. Disponível em: <http://www.eclac.cl/publicaciones/xml/4/21524/LCBRS147RobertoVermulm.pdf> 


\section{ANEXOS}

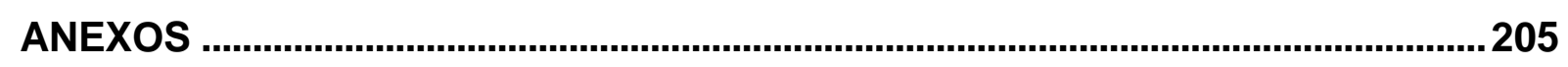

Anexo 1 - Classificação Nacional de atividade Econômica (CNAE) e a Nomenclatura Comum do Mercosul (NCM) para a indústria de bens de capital e a indústria de couro e calçados 206

Anexo 2 - Lista de empresas e instituições que colaboraram com a pesquisa empírica 209

Anexo 3 - Notas técnicas sobre empresas de máquinas para calçados 210

Himaco Hidráulicos e Máquinas Indústria e Comércio Ltda 210

Indústria de Máquinas ERPS Ltda 210

Ivomaq Indústria e Comércio de Máquinas Ltda 211

Máquinas Kehl Ltda 212

Máquinas Klein S/A Indústria e Comércio 213

Master Equipamentos Industriais Ltda . 214

Mecsul Máquinas e Equipamentos Ltda 214

Poppi Máquinas e Equipamentos Ltda. 215

Zambelli \& Cunha Ltda 216 Anexo 4 - Questionário aplicado em empresas de máquinas para calçados ......218 Anexo 5 - Questionário aplicado em empresas de calçados 227 Anexo 6 - Roteiro de questões aplicadas junto às instituições de apoio ao setor de máquinas para calçados. 


\section{ANEXO 1 - CLASSIFICAÇÃO NACIONAL DE ATIVIDADE ECONÔMICA (CNAE) E A NOMENCLATURA COMUM DO MERCOSUL (NCM) PARA A INDÚSTRIA DE BENS DE CAPITAL PARA COURO E CALÇADOS}

Quadro 1.1: Indústria de máquinas e equipamentos - Classificação Nacional de Atividade Econômica por grupos

\begin{tabular}{cl}
\hline Classificação & \multicolumn{1}{c}{ Grupos da Indústria de Máquinas e Equipamentos (CNAE 28) } \\
\hline 281 & Motores, bombas, compressores e equipamentos de transmissão. \\
282 & Máquinas e equipamentos de uso geral. \\
283 & Motores e equipamentos para a agricultura e pecuária. \\
284 & Máquinas-ferramentas. \\
285 & Máquinas e equipamentos de uso na extração mineral e na construção. \\
286 & Máquinas e equipamentos de uso industrial específico. \\
\hline Fonte: CNAE 2.0/CNAE Fiscal 2.0 - CONCLA (Comissão Nacional de Classificação). Disponível em: \\
http://www.cnae.ibge.gov.br/divisao.asp?coddivisao=29\&CodSecao=D\&TabelaBusca=CNAE 110@CNAE\%201.0\% \\
20/\%20CNAE\%20FISCAL1.1@1@cnae@1. Acesso em 31 de agosto de 2007.
\end{tabular}

Quadro 1.2: Grupo de máquinas e equipamentos de uso industrial específico Classificação Nacional de Atividade Econômica por classes

\footnotetext{
CNAE Classes de Máquinas e equipamentos de uso industrial específico (CNAE 286)

2861-5 Máquinas para a indústria metalúrgica, exceto máquina-ferramenta.

2862-3 Máquina e equipamentos para as indústrias de alimentos, bebida e fumo.

2863-1 Máquinas e equipamentos para a indústria têxtil.

2864-0 Máquinas e equipamentos para a indústria do vestuário, do couro e de calçados.

2865-8 Máquinas e equipamentos para as indústrias de celulose, papel e papelão e artefatos.

2866-6 Máquinas e equipamentos para a indústria dó plástico

2869-1 Máquinas e equipamentos para uso industrial específico, não especificado anteriormente.

Fonte: CNAE 2.0/CNAE Fiscal 2.0 - CONCLA (Comissão Nacional de Classificação). Disponível em:

http://www.cnae.ibge.gov.br/divisao.asp?coddivisao=29\&CodSecao=D\&TabelaBusca=CNAE 110@CNAE\%201.0\% 20/\%20CNAE\%20FISCAL1.1@1@cnae@1. Acesso em 31 de agosto de 2007.
} 


\section{Quadro 1.3: Classe de máquinas e equipamentos para a indústria do vestuário, do couro e de calçados (CNAE 2864-0) - Classificação Nacional de Atividade Econômica por subclasses (produtos)}

Produtos da subclasse de Máquinas e Equipamentos para a indústria do vestuário, do couro e de calçados (1).

Máquinas e aparelhos para as indústrias do vestuário e confecção de tecidos (para cortar, casear, pregar botões, bordar, etc).

Máquina e aparelhos para as indústrias do couro, curtumes, correaria, selaria, etc. (alisadores para couros, prensas, etc).

Máquinas e aparelhos para a indústria do calçado (pespontadeiras, máquinas para montar calçado, etc). Máquinas de tricotar.

Máquinas de costura de uso industrial.

Máquinas de costura de uso domestico.

Máquinas, aparelhos e equipamentos para instalações térmicas e hidráulicas em lavanderias, tinturarias e semelhantes.

Máquinas para reparação de calcados.

Cabeçotes para máquinas de costura.

Agulhas para máquinas de costura.

Pecas e acessórios para máquinas e equipamentos para as indústrias do vestuário e de couro e calcados

Instalação de máquinas e equipamentos para as indústrias do vestuário e de couro e calcados.

Fonte: CONCLA (Comissão Nacional de Classificação). Disponível em:

http://www.cnae.ibge.gov.br/divisao.asp?coddivisao=29\&CodSecao=D\&TabelaBusca=CNAE 110@CNAE\%201.0\% 20/\%20CNAE\%20FISCAL1.1@1@cnae@1. Acesso em 31 de agosto de 2007.

(1) Esta classe não compreende a fabricação de calandras (29.29); manutenção e reparação de máquinas e equipamentos para as indústrias do vestuário e de couro e calçados (29.96); A reparação de máquinas de costura de uso doméstico (52.71). 


\section{Quadro 1.4: Nomenclatura Comum do MERCOSUL (NCM) para a indústria de máquinas para couro e calçados}

\footnotetext{
Máquinas de costura, exceto as de costurar cadernos da posição 84.40; móveis, bases e tampas, próprios para máquinas de costura; agulhas para máquinas de costura - NCM 8452

8452.10.00 Máquinas de costura de uso doméstico

8452.2 Outras máquinas de costura:

8452.21 Unidades automáticas:

8452.21.10 Para costurar couros ou peles

8452.21.20 Para costurar tecidos

8452.21.90 Outras

$8452.29 \quad$ Outras

8452.29.10 Para costurar couros ou peles

8452.29.2 Para costurar tecidos

8452.29.21 Remalhadeiras

8452.29.22 Para casear

8452.29.23 Tipo zigue-zague para inserir elástico

8452.29.29 Outras

$8452.29 .90 \quad$ Outras

8452.30.00 Agulhas para máquinas de costura

8452.40.00 Móveis, bases e tampas, para máquinas de costura, e suas partes

$8452.90 \quad$ Outras partes de máquinas de costura

8452.90.1 Para máquina de costura de uso doméstico

8452.90.11 Guia-fios, lançadeiras e porta-bobina

8452.90.19 Outras

$8452.90 .9 \quad$ Outras

8452.90.91 Guia-fios, lançadeiras não rotativas e portas-bobina

8452.90.92 Para remalhadeiras

8452.90.93 Lançadeiras rotativas

8452.90.99 Outras

\begin{tabular}{|c|c|}
\hline fabricar ou & $\begin{array}{l}\text { Máquinas e aparelhos para preparar, curtir ou trabalhar couros ou peles, ou para } \\
\text { nsertar calçados e outras obras de couro ou de pele, exceto máquinas de costura - NCM } 8453\end{array}$ \\
\hline $\begin{array}{l}8453.10 \\
8453.10 .10\end{array}$ & $\begin{array}{l}\text { Máquinas e aparelhos para preparar, curtir ou trabalhar couros ou peles } \\
\text { Máquinas para dividir couros com largura útil inferior ou igual a } 3.000 \mathrm{~mm} \text {, com lâmina sem } \\
\text { fim, com controle eletrônico programável }\end{array}$ \\
\hline $\begin{array}{l}8453.10 .90 \\
8453.20 .00 \\
8453.80 .00 \\
8453.90 .00\end{array}$ & $\begin{array}{l}\text { Outros } \\
\text { Máquinas e aparelhos para fabricar ou consertar calçados } \\
\text { Outras máquinas e aparelhos } \\
\text { Partes }\end{array}$ \\
\hline
\end{tabular}

Fonte: Negociações Internacionais, Ministério do Desenvolvimento, Indústria e Comércio.

Disponível em: http://www.mdic.gov.br/arquivo/secex/claMerNcn/secao16/cap84.pdf. Acesso em 10 de outubro de 2007.
} 


\section{ANEXO 2 - LISTA DE EMPRESAS E INSTITUIÇÕES QUE COLABORARAM COM A PESQUISA EMPÍRICA}

Empresas de máquinas para calçados

- Himaco Hidráulicos e Máquinas;

- Indústria de Máquinas ERPS Ltda;

- Ivomaq Indústria e Comércio de Máquinas Ltda;

- Máquinas Kehl Ltda;

- Máquinas Klein Indústria e Comércio Ltda;

- Master Equipamentos Industriais Ltda;

- Mecsul Máquinas e Equipamentos Ltda;

- Poppi Máquinas e Equipamentos Ltda;

- Zambelli \& Cunha Ltda;

\section{Empresas de calçados}

- Via UNO;

- Calçados Chinesinha;

- Calçados Ferraroni;

- Biaggio Indústria e Comércio de Calçados Ltda.

Instituições de apoio ao setor de máquinas e de calçados

- ABRAMEQ;

- ABICALÇADOS;

- IBTec;

- IPT/Franca;

- SENAI/Porto Alegre;

- ABIMAQ;

- Grupo SINOS - Revista Lançamentos;

- ACl/Novo Hamburgo;

- Biblioteca do SENAI/ Novo Hamburgo;

- Biblioteca municipal de Novo Hamburgo;

- Biblioteca do IBTec. 


\section{ANEXO 3 - NOTAS TÉCNICAS SOBRE EMPRESAS DE MÁQUINAS PARA CALÇADOS}

\section{Himaco Hidráulicos e Máquinas Indústria e Comércio Ltda}

A Himaco iniciou suas atividades em 1969, em Novo Hamburgo (RS), com produção de máquinas para calçados. Em 1974, com a ascensão da indústria do plástico, a empresa começou a atuar no ramo de injetoras de plástico.

Atualmente, a empresa produz máquinas injetoras de plásticos que são utilizadas em vários setores: calçadista, utilidades domésticas, brinquedos, automobilístico, peças técnicas e farmacêuticas. No setor calçadista, as injetoras são utilizadas para produzir solado.

A Himaco conta com três linhas de máquinas (horizontais, verticais e rotativas) que totalizam 15 modelos, todos com tecnologia própria. Entretanto, a empresa especializa sua produção de acordo com a região: no Rio Grande do Sul, os produtos são voltados aos setores de calçados, automotivo, peças técnicas, utilidades domésticas e farmacêutica; em São Paulo, as vendas estão destinadas aos ramos calçadista, de utilidades domésticas e peças técnicas; em Minas Gerais e região Nordeste, a Himaco especializa sua produção para o setor de calçados.

$\mathrm{Na}$ área de comercialização e assistência técnica, a Himaco tem filial em Joinville (SC), Americana (SP), São Paulo (SP) e Curitiba (SP).

Fonte: Sítio da empresa; ABRAMEQ (2007) e Gazeta Mercantil (2000b)

\section{Indústria de Máquinas ERPS Ltda}

A ERPS foi fundada na cidade de Novo Hamburgo (RS) em 1975, com atividade voltada à produção de máquinas automáticas para a montagem de calçados (bicos, lados e calcanhar), e também fabrica máquinas para cambre, dublar, aplicar couraças e carimbar (numerar).

Atualmente, a empresa é a única fabricante brasileira de máquinas para calçado com tecnologias hidráulicas.

As principais linhas de produtos da ERPS são: 
- Máquinas para montagem de calçados;

- Outras máquinas;

- Máquinas para entretelar;

- Máquinas para cortar;

- Máquinas para carimbar e numerar;

- Máquinas aplicar couraças;

- Máquinas para moldar palas;

Fonte: Sítio da empresa; ABRAMEQ (2007) e Gazeta Mercantil (2000b)

\section{Ivomaq Indústria e Comércio de Máquinas Ltda}

A Ivomaq foi fundada em 1957 na cidade de Franca (SP), sob a denominação de Irmão Rodrigues Ltda, como uma oficina para o conserto de máquinas para calçados. Em 1972, a empresa mudou sua razão social para Ivomaq e iniciou as pesquisas para a produção de máquinas para "costura industrial", (pespontadeiras de coluna).

Atualmente a Ivomaq fabrica máquinas de costurar solados (blaqueadeira) e máquinas de costura industrial para o segmento de calçados, caracterizadas pelo sistema de corte de linha, motor eletrônico, programação de costuras e parada automática. Mas a empresa também atende à demanda dos segmentos de segurança, acessórios e vestuários em couros, bolsas, malas e ateliês de costura máquinas de costura para pequenos objetos de couro, sapatos com solado em látex; bolsas (em corino, couro, napa), mochila (lona e napa) e acessórios de couro.

As máquinas da Ivomaq são fabricadas a partir de encomendas dos clientes no mercado interno e externo. No mercado da costura de solados, a Ivomaq possui atendimento técnico comercial em todos continentes. Vendeu mais de 55.000 máquinas no Brasil e exterior (até maio 2006), e de acordo com o site da empresa, é a principal fabricante de máquinas de costura industrial para segmento de couro na América Latina, com mais de 43 diferentes modelos de máquinas, com automatizações como corte de fio e motor eletrônico.

No segmento de bolsas e artefatos de couro, a empresa possui atualmente uma linha de produtos que incorpora desde equipamentos simples, até modernas máquinas com triplo transporte, corte de fio automático, motor eletrônico, programação de pontos e controle de velocidade com parada posicionada. 
A Ivomaq possuiu um centro de treinamento com cursos na área de manutenção de máquinas de costura que já atendeu cerca de 4.000 pessoas. Os cursos estão divididos em três partes: curso básico (para técnicos mecânicos iniciantes ou com pouco conhecimento em costura); curso avançado (para técnicos com conhecimentos básicos e que procuram capacitação em automatização, motor eletrônico, corte de linha) e curso de manutenção produtiva (também para as máquinas de Costurar solados e de costura lateral).

Fonte: Sítio da empresa; ABRAMEQ (2007) e Gazeta Mercantil (2000b)

\section{Máquinas Kehl Ltda}

A Kehl foi fundada em 1970 na cidade de Novo Hamburgo, numa área de 3,5 mil $\mathrm{m}^{2}$. Atualmente o parque industrial da empresa ocupa uma área de mais de 10 mil m², na qual ela produz máquinas para calçados e para móveis e decoração.

A área principal de atuação da empresa é a produção de máquinas para calçados, que correspondia a $45 \%$ do seu faturamento em 1999. Nessa linha, a Klein fabrica máquinas para aplicar adesivo; dobrar tiras; carimbar solas, palmilhas e couro; e máquinas para aplicar metais (ilhoses, ganchos, etc).

A empresa tem uma sistemática de manter uma linha de produtos que apresentam maior demanda e produzir outros modelos sob encomenda dos clientes. O prazo médio de entrega dos produtos é de 30 dias após o pedido; e o prazo médio de pagamento é de 45 dias.

A comercialização dos produtos é realizada por meio de representação comercial, nos principais pólos de calçados. Atualmente a empresa conta com 21 representantes comerciais.

Em 1999, cerca de 10\% da produção de máquinas Kehl era exportada para os países da América Latina, Europa e Ásia.

Atualmente, a empresa fabrica as seguintes linhas de máquinas:

- Máquina para modelagem

- Máquinas para almoxarifado;

- Máquinas de Corte;

- Máquinas de pré-costura,

- Máquinas de Costura

- Máquinas de Montagem 
- Máquinas de Solas e pré-fabricados;

- Máquina para palmilhas;

- Máquinas para tiras;

- Máquinas auxiliares

Fonte: Sítio da empresa; ABRAMEQ (2007) e Gazeta Mercantil (2000b)

\section{Máquinas Klein S/A Indústria e Comércio}

A Klein começou suas atividades em 1945 em Novo Hamburgo (RS), sob a denominação de H. E. Klein \& Cia Ltda, fabricando lustres e artigos para iluminação. Em 1948, a razão social da empresa foi alterada para Klein, Martins \& Cia, e a empresa entrou no ramo de máquinas para calçados.

A unidade fabril da empresa apresenta uma área de $5,4 \mathrm{mil} \mathrm{m}^{2}$, na qual ela produz as seguintes linhas de máquinas:

- Balancins ponte;

- Máquinas de chanfrar;

- Máquinas de dividir;

- Alta freqüência;

- Máquinas para boné;

- Outras máquinas (fresar cepos desgastados de madeira, plástico, borracha e outros materiais sintéticos

As máquinas são utilizadas principalmente no setor de calçados - em 1999, cerca de $70 \%$ do faturamento da empresa era atribuído às vendas destinadas ao setor de calçados - sendo que os balacins e chanfradeiras são as máquinas mais vendidas. Entretanto, as máquinas Klein também são usadas nos segmentos de vestuário, borracha, papel, entre outros.

A fabricação das máquinas Klein é realizada sob pedido dos consumidores do setor calçadista nacional e de alguns países do MERCOSUL. O prazo médio de entrega dos produtos é de 30 dias; As formas de pagamento podem ser via leasing, Finame e consórcios, e os prazo são negociáveis (antecipado, à vista, parcelado).

Atualmente, a Klein conta com 17 representantes comerciais com atuação no mercado interno e regional (América Latina).

Fonte: Sítio da empresa; ABRAMEQ (2007) e Gazeta Mercantil (2000b) 


\section{Master Equipamentos Industriais Ltda}

A Master iniciou suas atividades de produção de máquinas para calçados no ano de 1972, na cidade de Novo Hamburgo (RS). Na década de 80 a empresa entrou também no ramo de equipamentos para curtumes.

Atualmente a Master trabalha numa área total de cerca de $5 \mathrm{mil} \mathrm{m2,}$ contando com mais 80 colaboradores diretos.

Os produtos destinados ao setor de calçados são as máquinas para conformar, prensas, fornos conformadores, estabilizadores a frio e máquinas de dividir couro. Os produtos são fabricados em série ou sob encomenda - quando os clientes solicitam alguma alteração.

O prazo médio de entrega dos produtos é de 30 dias após o pedido; e o pagamento pode ser efetuado entre 30 e 45 dias.

As máquinas fabricadas na empresa são comercializadas principalmente na região sul (50\%), em São Paulo (20\%) e nos Estados de Minas Gerais, Ceará e Bahia (30\%).

Produtos:

- Estabilização;

- Secagem e reativação;

- Prensagem de solas;

- Pinturas de saltos e solas;

- Medição;

- Exaustão;

- Transportadores e esteiras

Fonte: Sítio da empresa; ABRAMEQ (2007) e Gazeta Mercantil (2000b)

\section{Mecsul Máquinas e Equipamentos Ltda}

A unidade fabril da Mecsul foi fundada em 1981, na cidade de Novo Hamburgo (RS). Em junho de 1998, a empresa efetuou uma joint venture com a empresa italiana Sabal, visando à melhoria tecnológica de seus produtos.

A Mecsul produz máquinas couro e calçados voltadas às atividades de conformar, pregar saltos, tirar rugas, secar e transporte, totalizando mais de 50 modelos de máquinas. Os modelos podem ser classificados nas seguintes linhas de máquinas: 
- Secador e Reativador Horizontal Ultra Rápido;

- Conformador Compacto de Alto Desempenho;

- Forno Conformador de Altíssimo Desempenho;

- Câmara Automática de Reativação e Vaporização do Cabedal;

- Câmara Automática de Reativação e Vaporização do Cabedal;

- Secador Vertical Ultra-Rápido;

- Máquina de Conformar Contraforte;

- Conformadora Térmica;

- Máquina de Pregar Saltos Hidropneumática;

- Vaporizadora e Reativadora para Cabedais;

- Máquina para tirar rugas do calçado Ultra-Rápida;

- Estufa com Ar Quente Circulante;

- Estufa Vaporizadora e Reativadora com ar forçado para Cabedais;

- Máquina de Secagem;

- Fitas transportadoras de produção;

- Fissare;

- Máquina de Mono-posto para Pré-Conformar; e

- Transportadoras de Produção.

As máquinas da Mecsul são produzidas em série ou sob encomenda dos clientes, com adaptações e sugestões de melhorias. O prazo médio de entrega dos produtos sob encomenda é de 30 dias, e o pagamento pode ser realizado em até 90 dias.

Fonte: Sítio da empresa; ABRAMEQ (2007) e Gazeta Mercantil (2000b)

\section{Poppi Máquinas e Equipamentos Ltda}

A Poppi foi fundada no ano de 1960, na cidade de Franca (SP), com atividades voltadas à produção de máquinas para calçados e confecções e prestação de serviço de assistência técnica e reposição de peças. Atualmente, a empresa também tem uma unidade fabril na cidade de Novo Hamburgo (RS) para facilitar a participação nos SLPs da região sul.

As máquinas fabricadas pela Poppi são destinadas ao corte de couro e à preparação e montagem de todos os tipos de calçados, sendo classificadas nos seguintes modelos de máquinas: 
- Prensa hidráulica para corte (balancim de corte);

- Prensa hidráulica de ponte para corte (balancim de ponte);

- Máquinas de dividir couros; chanfrar peças em couro; aplicar couraças (reforços) termoplásticos; moldar e conformar contrafortes;

- Vaporizadores de cabedais para montagem;

- Máquina de apontar e montar calçados e laterais de calçados, com aplicação automática de adesivo termoplástico a frio;

- Máquina de montar bases de calçados com aplicação automática de adesivo termoplástico a frio ou de tachas;

- Forno conformador de calçados;

- Prensas hidráulicas ou pneumáticas para colagem de solados;

- Lixadeiras rotativas; e

- Lustros rotativos.

A empresa organiza sua produção através de uma programação previamente estabelecida de acordo com pesquisas e necessidades de consumo do setor. Nesse sentido, não há máquinas fabricadas sob encomenda. Após o pedido ser efetuado, o prazo de entrega é de 5 a 30 dias. As formas de pagamento podem ser à vista, financiamento próprio (até 5 vezes), leasing e Finame.

Fonte: Sítio da empresa; ABRAMEQ (2007) e Gazeta Mercantil (2000b)

\section{Zambelli \& Cunha Ltda}

A Zambelli e Cunha foi fundada em 2003, na cidade de Novo Hamburgo (RS) e seu parque fabril apresenta cerca de 1,5 mil metros quadrados.

A empresa fabrica mais de 150 modelos de máquinas para calçados, que estão divididas nas seguintes linhas:

- Máquinas para lixar e polir (lixadeiras e politris);

- Máquinas para fresar e asperar (arredondar, asperar, atoalhar, perfilar e préfresa);

- Máquinas para corte (chanfrar, cortar, dividir, entalhar, perfurar, rachar, refilar).

- Máquinas para prensar (prensar, rebater, sentar costura, cilindrar couro, colar fita);

- Máquinas para gravar e marcar (marcar altura, serrilhar); 
- Máquinas para montar (apontar sapato, enfiar tira, montar sapato, torno de montagem);

- Máquinas para industriais (estufa reativadora, cabine ultravioleta, bobinar rolos, bobinar tiras, coletor de pó)

A principal linha de máquinas são os pré-fabricados (lixadeiras, fresas, máquinas de corte, aspiração, polimento, prensas e coletores de pó) que respondem por $80 \%$ da produção da empresa.

A empresa também fabrica máquinas especiais para as áreas médica, hospitalar, moveleira e para o setor de borracha, além de dispositivos técnicos e ferramentas como fresas e navalhas para corte de tiras.

Adicionalmente, a Zambelli disponibiliza serviços de usinagem em geral como retífica plana, plaina, fresa, torno, solda e montagem; manutenção de máquinas para calçados; e outros serviços mais específicos:

- Afiação de navalhas de corte;

- Rebobinamento de materiais em rolo;

- Divisão ou corte de bobinas de material têxtil ou sintético;

- Recuperação de ferramentas de carbeto;

- Pintura a pó;

- Usinagem CNC;

As formas de pagamento a partir de financiamento estão disponíveis através dos programas do BNDES, Banco do Brasil (PROEX) e do BRDE. Fonte: Sítio da empresa; ABRAMEQ (2007) e Gazeta Mercantil (2000b) 


\section{ANEXO 4 - QUESTIONÁRIO APLICADO EM EMPRESAS DE MÁQUINAS PARA CALÇADOS}

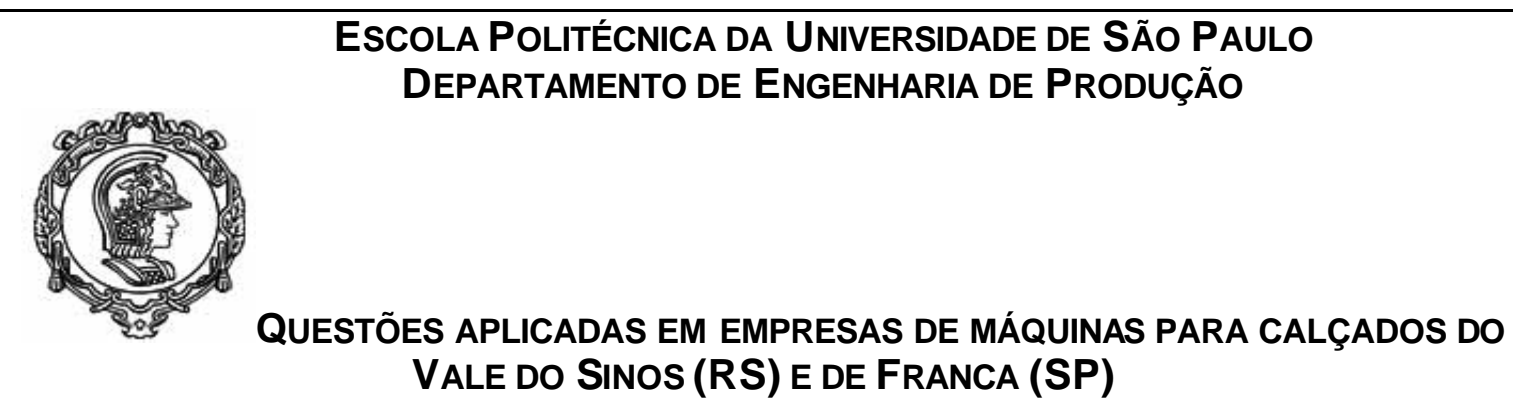

Data de realização da entrevista:

Tempo de duração:

A) Identificação e característica da empresa investigada

1. Dados Gerais da empresa investigada

Nome fantasia:

Ano de fundação:

Linha de produtos:

Característica da Linha de produtos:

2. Identificação do entrevistado e de sua trajetória na empresa

Nome:

Cargo:

Tempo de empresa:

Formação:

3. Dados sobre as unidades de produção

Número e localização das unidades no Brasil:

Número e localização das unidades produtivas no exterior

Capacidade de produção anual (volumes)

Nível atual de utilização da capacidade produtiva (\%)

Número de turnos trabalhados

4. Produto e vendas

Descrição das linhas de produtos: 


\begin{tabular}{|l|l|c|c|c|c}
\hline $\begin{array}{c}\text { Linha de } \\
\text { produtos }\end{array}$ & $\begin{array}{c}\text { Principais } \\
\text { produtos }\end{array}$ & $\begin{array}{c}\text { Idade média } \\
\text { das linhas de } \\
\text { produtos }\end{array}$ & $\begin{array}{c}\text { Departamento de } \\
\text { projeto interno } \\
\text { (sim/não) }\end{array}$ & $\begin{array}{c}\text { Participação no } \\
\text { faturamento } \\
\text { (\%) }\end{array}$ & $\begin{array}{c}\text { Investimentos } \\
\text { (\% e descrição) }\end{array}$ \\
\hline Seriados & & & & & \\
\hline Sob encomenda & & & & & \\
\hline
\end{tabular}

Divisão das vendas entre as quatro principais linhas de produtos (mercado interno e externo):

\begin{tabular}{|l|c|c|c|}
\hline $\begin{array}{c}\text { Linha de } \\
\text { produtos }\end{array}$ & $\begin{array}{c}\text { Participação das vendas } \\
\text { no mercado interno } \\
(\%)\end{array}$ & $\begin{array}{c}\text { Participação das vendas } \\
\text { no mercado externo } \\
(\%)\end{array}$ & Mercados \\
\hline Seriados & & & \\
\hline Sob encomenda & & & \\
\hline
\end{tabular}

5. A empresas já terceirizou alguma atividade/etapa da produção? Por quê?

\section{B) Características da dinâmica tecnológica}

1. O que a empresa considera mais importante para a sua competitividade no mercado interno e externo?

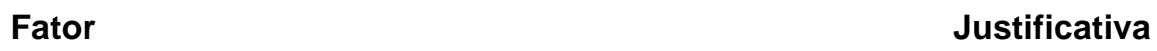

Custo ( )

Projeto de produto ( )

Qualidade ( )

Flexibilidade ( )

Produtividade ( )

Outro - qual ( )

2. Qual o tempo médio (meses, anos) que a empresa leva para criar um novo produto?

E para alterar as características (incrementais) de produtos e dos processos (atualização)?

3. O conhecimento técnico (tarefas cotidianas) é:

\begin{tabular}{|l|l|l|}
\hline \multicolumn{1}{|c|}{ Especialização e divisibilidade } & \multicolumn{1}{|c|}{$\begin{array}{c}\text { Informações técnicas } \\
\text { internas à empresa }\end{array}$} \\
\hline \multicolumn{2}{|c|}{ Produto } & \multicolumn{1}{|c|}{} \\
\hline Nível de especialização requerida para sua execução & \\
\hline Especializado (realizado somente por funcionários capacitados) & & \\
\hline Diversificado (realizado por todos os funcionários) & & \\
\hline Misto (especializado e diversificado) & & \\
\hline Nível de divisibilidade das informações técnicas & \\
\hline Dividido em etapas (transferido facilmente - especificar deptos) & & \\
\hline Não divisível & & \\
\hline
\end{tabular}

4. Sobre os instrumentos de proteção das informações, quais os mais usados pela empresa? Eles são eficazes? Há dificuldades (quais)? 


\begin{tabular}{|l|l|l|l|l|}
\hline \multirow{2}{*}{$\begin{array}{c}\text { Mecanismos de } \\
\text { proteção das } \\
\text { informações }\end{array}$} & $\begin{array}{c}\text { Eficácia } \\
\text { (sim/não) }\end{array}$ & $\begin{array}{c}\text { Dificuldades } \\
\text { (dificuldade alta, } \\
\text { media ou baixa) }\end{array}$ & $\begin{array}{c}\text { Eficácia } \\
\text { (sim/não) }\end{array}$ & $\begin{array}{c}\text { Dificuldades } \\
\text { (dificuldade alta, } \\
\text { media ou baixa) }\end{array}$ \\
\cline { 2 - 5 } & & & & \\
\hline Patente ( ) & & & & \\
\hline Defasagem temporal ( ) & & & & \\
\hline Complexidade ( ) & & & & \\
\hline Aprendizado ( ) & & & & \\
\hline Outros ( ) & & & & \\
\hline
\end{tabular}

5. A empresa depositou alguma patente referente à mudança tecnológica nos seus produtos e/ou processos? Sim (1); Não (2).

No Brasil? Sim (1); Não (2). Quantas e quais?

No exterior? Sim (1); Não (2). Quantas e quais?

6. A empresa realizou algum pagamento referente às mudanças tecnológicas e/ou organizacionais recentes em seus produtos e/ou processos? Sim (1) Não (2) Modalidade

Valor

7. A empresa recebeu algum pagamento referente às mudanças tecnológicas e/ou organizacionais recentes em seus produtos e/ou processos? Sim (1) Não (2) Modalidade

Valor

\section{C) Características das fontes de informação (interna e externa) às empresas}

8. Como as informações são trocadas no ambiente interno a empresa, nas etapas produto e processo?

Fonte de informação interna (dê exemplos)

\begin{tabular}{|l|l|l|}
\hline & Produto & Processo \\
\hline Reuniões periódicas e cooperação entre os departamentos. & & \\
\hline Reuniões freqüentes e cooperação entre os departamentos. & & \\
\hline Reuniões periódicas e cooperação num mesmo departamento. & & \\
\hline Reuniões freqüentes e cooperação num mesmo departamento. & & \\
\hline A partir de cursos. & & \\
\hline A partir de treinamento. & & \\
\hline Outros (quais?) & & \\
\hline
\end{tabular}

9. Quais as dificuldades para desenvolver e melhorar as informações internas em produtos e processos?

10. Quais dos mecanismos a seguir a empresa utilizou (tem utilizado) para resolver as dificuldades na gestão de informações nos departamentos:

Formação profissional e técnica dos funcionários do chão-de-fábrica ( );

Contratação de funcionários com maior experiência profissional ( );

Cursos de gestão para os gerentes de produto/processo ( );

Contratação de gerentes mais capacitados ( );

Contratação de engenheiros ( );

Outros - exemplifique ( ). 
11. Como as informações externas de produto e processo chegam ao ambiente interno das empresas?

Fonte de informação externa (dê exemplos)

\begin{tabular}{|c|c|c|c|c|c|}
\hline & \multicolumn{2}{|c|}{ Linha de Seriados } & \multicolumn{2}{|c|}{ Linha Sob encomenda } & \multirow{2}{*}{$\begin{array}{c}\text { Local } \\
\text { (SLP, } \\
\text { nacional ou } \\
\text { no exterior) }\end{array}$} \\
\hline & Produto & Processo & Produto & Processo & \\
\hline Consumidores/usuários & & & & & \\
\hline $\begin{array}{l}\text { Fornecedores de insumos/ } \\
\text { componentes }\end{array}$ & & & & & \\
\hline \begin{tabular}{|lll}
$\begin{array}{l}\text { Fornecedores de máquinas de } \\
\text { outros segmentos }\end{array}$ & \\
\end{tabular} & & & & & \\
\hline Institutos de P\&D/Universidades & & & & & \\
\hline Outros (quais?) & & & & & \\
\hline
\end{tabular}

12. A empresa passou (ou tem passado) por dificuldades para transformar informações tecnológicas externas em novas aplicações para o mercado?

Em qual Área/departamento ocorreu?

Projeto (1); Produção (2); Controle de qualidade (3); Marketing (4); Outros exemplifique (5)

13. Como a empresa classifica as estratégias a seguir para transformar as informações externas em melhorias em produtos e processos:

a) Formação profissional e técnica dos funcionários do chão-de-fábrica:

b) Contratação de funcionários com mais experiência profissional:

c) Cursos de gestão para os gerentes de produto/processo:

d) Contratação de gerentes mais capacitados:

e) Contratação de engenheiros:

f) Outros - exemplifique:

14. Qual o mecanismo mais comum para o aprendizado interno e externo à empresa:

\begin{tabular}{|l|c|c|c|c|}
\hline \multicolumn{1}{|c|}{$\begin{array}{c}\text { Aprendizado } \\
\text { interno }\end{array}$} & \multicolumn{2}{c|}{$\begin{array}{c}\text { Áreas em que ocorre o } \\
\text { aprendizado }\end{array}$} & $\begin{array}{c}\text { Funcionamento } \\
\text { (ruim, moderado } \\
\text { ou bom) }\end{array}$ & $\begin{array}{c}\text { Intensidade } \\
\text { (baixa, } \\
\text { intermediaria } \\
\text { ou continua) }\end{array}$ \\
\hline & Produto & Processo & & \\
\hline Na etapa de produção & & & & \\
\hline Ao usar uma tecnologia de outros & & & & \\
\hline Ao interagir com os usuários & & & & \\
\hline Outro - exemplifique & & & & \\
\hline
\end{tabular}

\begin{tabular}{|l|l|l|l|l|l|}
\hline $\begin{array}{c}\text { Aprendizado } \\
\text { externo }\end{array}$ & \multicolumn{2}{|c|}{$\begin{array}{c}\text { Áreas em que } \\
\text { ocorre o aprendizado }\end{array}$} & $\begin{array}{c}\text { Funcionamento } \\
\text { (ruim, moderado } \\
\text { ou bom) }\end{array}$ & $\begin{array}{c}\text { Intensidade } \\
\text { (baixa, } \\
\text { intermediaria ou } \\
\text { continua) }\end{array}$ & $\begin{array}{c}\text { Local } \\
\text { (SLP, fora do } \\
\text { SLP e nacional, } \\
\text { estrangeiro) }\end{array}$ \\
\hline & Produto & Processo & & & \\
\hline Imitação & & & & & \\
\hline Cooperação & & & & & \\
\hline
\end{tabular}




\begin{tabular}{|l|l|l|l|l|} 
Interação & & & & \\
\hline Outros & & & & \\
\hline
\end{tabular}

15. Quais departamentos/funcionários são responsáveis pela transferência das informações (externas) para as atividades de projeto e produção (interno)? Como eles interferem/gerenciam nesse processo?

16. Atualmente, a empresa tem alguma parceria/cooperação voltada para o aprendizado de produtos e processos? Por quê?

\begin{tabular}{|l|l|l|l|}
\hline \multirow{2}{*}{ Agentes } & \multicolumn{2}{c|}{$\begin{array}{c}\text { Parcerias } \\
\text { /cooperação }\end{array}$} & $\begin{array}{c}\text { Local } \\
\text { (SLP, fora do SLP e } \\
\text { nacional, } \\
\text { estrangeiro) }\end{array}$ \\
\cline { 2 - 4 } & $\begin{array}{c}\text { Produto } \\
\text { (exemplos) }\end{array}$ & $\begin{array}{c}\text { Processo } \\
\text { (exemplos) }\end{array}$ & \\
\hline Consumidores/usuários & & & \\
\hline Fornecedores de insumos/componentes & & & \\
\hline $\begin{array}{l}\text { Fornecedores de máquinas de outros } \\
\text { segmentos }\end{array}$ & & & \\
\hline $\begin{array}{l}\text { Convênio com Institutos de } \\
\text { P\&D/Universidades }\end{array}$ & & & \\
\hline Outros (quais?) & & & \\
\hline
\end{tabular}

17. A empresa tem algum acordo com concorrentes para o desenvolvimento e/ou comercialização de produtos e tecnologias? Como classificaria os riscos envolvidos nessas relações?

\begin{tabular}{|c|c|c|c|c|c|c|}
\hline \multirow{3}{*}{ Agentes } & \multicolumn{2}{|c|}{$\begin{array}{c}\text { Acordo com os } \\
\text { concorrentes }\end{array}$} & $\begin{array}{c}\text { Local } \\
\text { (SLP, nacional } \\
\text { ou no exterior) }\end{array}$ & \multicolumn{3}{c|}{ Riscos } \\
\cline { 2 - 7 } & Processo & Produto & & Reduzidos & Aceitáveis & Muito alto \\
\hline & & & & & & \\
\hline
\end{tabular}

D) Características conversão do conhecimento, inclusive das relações com usuários do setor de calçados

18. A empresa considera que as relações estabelecidas com usuários nos últimos anos ampliaram as condições para o desenvolvimento das suas informações técnicas internas? Sim (1); Não (2).

\begin{tabular}{|l|c|c|c|}
\hline \multicolumn{1}{|c|}{$\begin{array}{c}\text { Relações } \\
\text { usuário-produtor }\end{array}$} & \multicolumn{2}{c|}{ Linha de produtos } & Processos \\
\hline & Seriados & $\begin{array}{c}\text { Sob } \\
\text { encomenda }\end{array}$ & \\
\hline Nível de participação dos usuários & & & \\
\hline $\begin{array}{l}\text { Direta (com participação nas fases iniciais } \\
\text { de especificação e de projeto) }\end{array}$ & & & \\
\hline $\begin{array}{l}\text { Indireta (sem a participação na } \\
\text { especificação e projeto) }\end{array}$ & & & \\
\hline
\end{tabular}




\begin{tabular}{|l|l|l|l|}
$\begin{array}{l}\text { Contribuição para os produtores de } \\
\text { máquinas }\end{array}$ & & & \\
\hline Instável & & & \\
\hline Relevante & & & \\
\hline Muito relevante & & & \\
\hline Efeitos sobre as competências internas & & & \\
\hline $\begin{array}{l}\text { Produtos: melhoria significativa das } \\
\text { competências internas (1); apresentou } \\
\text { poucas mudanças (2); não contribui para } \\
\text { essas competências (3). }\end{array}$ & & & \\
\hline $\begin{array}{l}\text { Processos: melhoria significativa das } \\
\text { competências internas (1); apresentou } \\
\text { poucas mudanças (2); não contribui para } \\
\text { essas competências (3) }\end{array}$ & & & \\
\hline
\end{tabular}

19. Como a empresa classifica a natureza das relações com usuários:

a) Fechada e seletiva (1); b) Aberta e difusa (2).

20. Como a empresa estabelece e mantém as relações com usuários?

a) Com contratos formais de pós-venda (1);

b) Com contratos informais (2);

c) Sem contratos formais e informais, mas com reuniões periódicas (3);

d) Outras opções (quais) (4).

21. Quais as principais necessidades dos seus usuários com a aquisição de suas linhas de produtos?

\begin{tabular}{|c|l|}
\hline Descrição & Justificativa \\
\hline Redução de custos ( ) & \\
\hline Melhoria na qualidade ( ) & \\
\hline Aumento da flexibilidade ( ) & \\
\hline Maior produtividade ( ) & \\
\hline Outro - qual ( ) & \\
\hline
\end{tabular}

22 Quais são as maiores dificuldades identificadas nas relações com os usuários para as mudanças nas competências dos produtores:

Muito difícil: 1; Dificuldade moderada: 2; Sem dificuldade: (3)

\begin{tabular}{|c|c|c|c|}
\hline \multirow[b]{2}{*}{ Relações usuário-produtor } & \multicolumn{2}{|c|}{ Linha de produtos } & \multirow[t]{2}{*}{ Processos } \\
\hline & Seriados & $\begin{array}{c}\text { Sob } \\
\text { encomenda }\end{array}$ & \\
\hline Variação constante da moda & & & \\
\hline $\begin{array}{l}\begin{array}{l}\text { Substituição e incorporação de novos } \\
\text { materiais }\end{array} \\
\end{array}$ & & & \\
\hline Demanda de pequenos lotes (específicos) & & & \\
\hline $\begin{array}{l}\text { Entender os requisitos dos clientes e } \\
\text { traduzir em termos técnicos }\end{array}$ & & & \\
\hline $\begin{array}{l}\text { Habilidade dos funcionários para lidar com } \\
\text { as flutuações em pedidos }\end{array}$ & & & \\
\hline Outros & & & \\
\hline
\end{tabular}

23 Qual o nível de importância atribuída aos seguintes fatores para o aprendizado das relações com usuários : 
a) Formação profissional e técnica: nula (1); moderada - depende também de outros fatores (2); importante (3); muito importante (4).

b) Interação entre os departamentos: nula (1); moderada - depende também de outros fatores (2); importante (3); muito importante (4).

c) Ruptura e incorporação contínua de novos elementos às rotinas internas: nula (1); moderada - depende também de outros fatores (2); importante (3); muito importante (4).

d) Outros fatores.

E) Efeitos da conversão do conhecimento (a partir da interação com os usuários) para o desempenho das empresas de máquinas.

24. Para a empresa, a natureza da tecnologia tem sido ou pode ser alterada por relações com fontes externas de informação (com os usuários)? Como?

25. Exemplifique as tecnologias ou práticas organizacionais associadas ao processo produtivo mais importante para a empresa ser competitiva na indústria:

Tecnologia de processo (1);

Práticas organizacionais (2).

26. As tecnologias de processo têm característica estável (1) ou estão em constante mudança (2)?

As práticas organizacionais têm característica estável (1) ou estão em constante mudança (2)?

27 Como a empresa acompanha as mudanças em tecnologias de processo e as mudanças nas práticas organizacionais?

28. As (s) mudanças (s) nas competências tecnológicas e organizacionais representaram novidades para: mercado mundial (1); mercado regional (2); mercado nacional (3); apenas para a empresa (4).

29. Quem desenvolveu/realizou essas mudanças: empresa (1); concorrentes (2); parceiros (3); terceiros (4). Onde foi desenvolvida essa competência: Brasil (1); principalmente no exterior (2) - qual o (s) país (países).

30. Quais os principais resultados da mudança de produtos e processos para a empresa?

\begin{tabular}{|l|l|l|}
\hline \multicolumn{1}{|c|}{ Resultados } & $\begin{array}{c}\text { Mudanças em } \\
\text { produtos }\end{array}$ & $\begin{array}{c}\text { Mudanças em } \\
\text { processos }\end{array}$ \\
\hline Aumento das vendas & & \\
\hline Desenvolvimento de novos produtos & & \\
\hline Aumento das exportações & & \\
\hline Diversificação & & \\
\hline Melhoria da qualidade & & \\
\hline Redução dos custos & & \\
\hline Adequação as normas nacionais & & \\
\hline Adequação as normas estrangeiras & & \\
\hline Adequar as exigências da demanda & & \\
\hline Melhorar as condições de trabalho & & \\
\hline
\end{tabular}




\begin{tabular}{|l|l|l|}
$\begin{array}{l}\text { Melhorou as condições para trabalhar } \\
\text { com novos materiais }\end{array}$ & & \\
\hline Aumentou a base microeletrônica/técnica & & \\
\hline Outras & & \\
\hline
\end{tabular}

F) Fatores que podem interferir na capacidade de absorção do conhecimento entre empresas produtoras e usuárias de máquinas

31. Quais as fontes de investimentos utilizados pela empresa no desenvolvimento de produtos e processos?

32. Se a fonte for empréstimo ou acesso a programas de financiamento público/privado, quais as principais dificuldades enfrentadas na obtenção dos financiamentos?

33. Quais os principais destinos dos investimentos realizados nos últimos três anos:

a) $\mathrm{RH}$ - contratação de funcionários: $\mathrm{R} \$$ :

b) $\mathrm{RH}$ - cursos de capacitação: $\mathrm{R} \$$ : $\%$ das vendas;

c) Aquisição de máquinas e equipamentos: $R \$$ : $\%$ das vendas; vendas;

d) Reforma ou ampliação da unidade de produção: $R \$$ : $\%$ das das vendas;

e)Reforma ou melhoria da unidade de projeto: $R \$$ : vendas;

f) Participação em feiras nacionais: $R$ :

g) Participação em feiras/eventos internacionais: $R \$$ : vendas;

h) Outros (especifique): $R \$$ : $\%$ das vendas.

34. Em quais áreas/departamentos/funções a empresa pretende aplicar os investimento nos próximos três anos?
a) $\mathrm{RH}$ - contratação de funcionários: $\mathrm{R} \$$ :
b) $\mathrm{RH}$ - cursos de capacitação: $\mathrm{R} \$$ : $\%$ das vendas; $\%$ das vendas;

c) Aquisição de máquinas e equipamentos: $R \$$ : vendas;

d) Reforma ou ampliação da unidade de produção: $R$ \$: $\%$ das das vendas;

e) Reforma ou melhoria da unidade de projeto: $R \$$ : $\%$ das vendas; $\%$ das vendas;

f) Participação em feiras nacionais: $R$ \$: $\%$ das vendas;

g) Participação em feiras/eventos internacionais: $R \$$ : vendas;

h) Outros (especifique): $R \$$ : $\%$ das vendas.

G) Características dos atores envolvidos no processo de interação inovativa entre empresas usuárias e produtoras

35. As instituições representativas têm atuado nas melhorias em produtos e processos: ativas (1) ou passivas (2). Se forem ativas, classifique em: fraca (3); 
moderada (4); forte (5)

36. Quais instituições têm atuado nas melhorias adotadas pela empresa:

a) Investimentos em pesquisa :

b) Investimentos em teste e melhoria de produtos/processos:

c) Aquisição ou criação de competências:

d) Inserção em novos mercados (comercialização):

e) Outros (especifique):

37. Como a empresa tem enfrentado a concorrência com os produtos chineses nos últimos anos. E qual a aposta para os próximos anos

38. Observações gerais sobre a empresa - organização industrial e produtiva e planejamento de longo prazo:

H) Características e dados sobre a mão-de-obra

Número de empregados:

\begin{tabular}{|c|c|c|}
\hline \multirow{2}{*}{ Empregados } & \multicolumn{2}{|c|}{ Número de empregados } \\
\cline { 2 - 3 } & $31 / \mathrm{dez} / 2005$ & $31 / \mathrm{dez} / 2006$ \\
\hline Diretos & & \\
\hline Indiretos & & \\
\hline Total & & \\
\hline
\end{tabular}

Perfil dos empregados:

\begin{tabular}{|c|c|c|}
\hline Setor & $\begin{array}{c}\text { Descrição } \\
\text { do cargo }\end{array}$ & $\begin{array}{c}\text { № de } \\
\text { funcionários }\end{array}$ \\
\hline Administração & & \\
\hline Projeto & & \\
\hline Produção & & \\
\hline
\end{tabular}

Curso de capacitação ou qualificação de seus funcionários

Não realiza

Realiza na empresa, em serviço

Realiza na empresa, em atividade específica de treinamento (curso)

Realiza fora da empresa

\begin{tabular}{|l|}
\hline 01 \\
\hline 02 \\
\hline 03 \\
\hline 04 \\
\hline
\end{tabular}

Instituição ou o agente realizador da qualificação e/ou capacitação da mão-de-obra: 


\title{
ANEXO 5 - QUESTIONÁRIO APLICADO EM EMPRESAS DE CALÇADOS
}

\author{
ESCOLA POLITÉCNICA DA UNIVERSIDADE DE SÃo PAULO \\ Departamento de EngenhaRIA de Produção
}

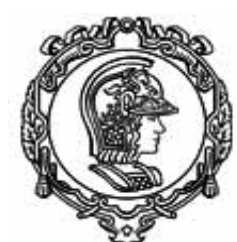

QUESTÕES APLICADAS EM EMPRESAS DE CALÇAdOS FEMININOS DO VALE DO SinOS (RS) E EM EMPRESAS DE CALÇADOS MASCULINOS DE FRANCA (SP)

Data de realização da entrevista:

Tempo de duração:

A) Identificação e característica da empresa investigada

1. Dados Gerais da empresa investigada

Nome fantasia:

Ano de fundação:

Origem de capital:

Atividades principais (linha de produtos):

2. Identificação do entrevistado e de sua trajetória na empresa

Nome:

Cargo:

Tempo de empresa:

Formação:

3. Dados sobre as unidades de produção

Número e localização das unidades no Brasil:

Número e localização das unidades no exterior:

Capacidade de produção anual (volumes):

Nível atual de utilização da capacidade produtiva (\%):

Número de turnos trabalhados:

\section{Produto e vendas}

Descrição das linhas de produtos: 


\begin{tabular}{|c|c|c|}
\hline $\begin{array}{l}\text { Linha de } \\
\text { Produtos }\end{array}$ & $\begin{array}{c}\text { Principais } \\
\text { produtos }\end{array}$ & $\begin{array}{c}\text { Participação no } \\
\text { faturamento } \\
(\%)\end{array}$ \\
\hline & & \\
\hline
\end{tabular}

Divisão das vendas entre as quatro principais linhas de produtos (mercado interno e externo):

\begin{tabular}{|c|c|c|c|}
\hline $\begin{array}{c}\text { Linha de } \\
\text { produtos }\end{array}$ & $\begin{array}{c}\text { Participação das vendas } \\
\text { no mercado interno } \\
(\%)\end{array}$ & $\begin{array}{c}\text { Participação das vendas } \\
\text { no mercado externo } \\
(\%)\end{array}$ & Mercados \\
\hline & & & \\
\hline
\end{tabular}

5. A empresas já terceirizou alguma atividade/etapa da produção? Por quê?

\section{B) Características das relações estabelecidas com produtores de máquinas para calçados}

6. Quais as máquinas mais importantes para a produção de calçados (quais os modelos e empresas fornecedoras)?

7. Em quais etapas a empresa produtora de máquinas participa das atividades com a empresa de calçados?

8. Nos últimos três anos, a empresa de calçados tem investido na aquisição de máquinas para calçados? Quais as etapas que tem demandado esses investimentos?

9. Os fornecedores de máquinas são empresas nacionais ou estrangeiras? De quais regiões?

10. Quando ocorre a interação entre os calçadistas e os fornecedores de máquinas (quando é comum?):

Antes da produção - dá as especificações para a empresa de máquinas (1). Explique:

Durante a produção - modificações das máquinas para resolver problemas (2). Explique:

11. Como ocorre a interação com os fornecedores de máquina? (Descrever o que acontece na maioria das vezes).

12. Preencha o quadro a seguir:

\begin{tabular}{|l|l|l|l|}
\hline \multicolumn{1}{|c|}{ Relações usuário-produtor } & \multicolumn{2}{c|}{ Linha de produtos } & Processos \\
\cline { 2 - 4 } & Seriados & $\begin{array}{c}\text { Sob } \\
\text { encomenda }\end{array}$ & \\
\hline $\begin{array}{l}\text { Nível de participação dos produtores de } \\
\text { máquinas }\end{array}$ & & & \\
\hline $\begin{array}{l}\text { Direta (com participação nas fases iniciais } \\
\text { de especificação e de projeto) }\end{array}$ & & & \\
\hline Indireta (sem a participação na & & & \\
\hline
\end{tabular}




\begin{tabular}{|l|l|l|l|} 
lespecificação e projeto) & & & \\
\hline $\begin{array}{l}\text { Contribuição para as empresas de } \\
\text { calçados }\end{array}$ & & & \\
\hline Instável & & & \\
\hline Relevante & & & \\
\hline Muito relevante & & & \\
\hline Efeitos sobre as competências internas & & & \\
\hline $\begin{array}{l}\text { Produtos: melhoria significativa das } \\
\text { competências internas (1); apresentou } \\
\text { poucas mudanças (2); não contribui para } \\
\text { essas competências (3). }\end{array}$ & & & \\
\hline $\begin{array}{l}\text { Processos: melhoria significativa das } \\
\text { competências internas (1); apresentou } \\
\text { poucas mudanças (2); não contribui para } \\
\text { essas competências (3) }\end{array}$ & & & \\
\hline
\end{tabular}

13. Como a empresa classifica a natureza das relações com os produtores de máquinas:

a) Fechada e seletiva (1); b) Aberta e difusa (2).

14. Como a empresa estabelece e mantém as relações com os produtores de máquinas?

a) Com contratos formais de pós-venda (1);

b) Com contratos informais (2);

c) Sem contratos formais e informais, mas com reuniões periódicas (3);

d) Outras opções (quais) (4).

15. Quais são as maiores dificuldades identificadas nas relações com os produtores de máquinas para as mudanças nas competências das empresas de calçados:

Muito difícil: (1); Dificuldade moderada: (2); Sem dificuldade: (3)

\begin{tabular}{|l|l|l|l|}
\hline \multirow{2}{*}{ Relações usuário-produtor } & \multicolumn{2}{c|}{ Linha de produtos } & Processos \\
\cline { 2 - 4 } & Seriados & $\begin{array}{c}\text { Sob } \\
\text { encomenda }\end{array}$ & \\
\hline Variação constante da moda & & & \\
\hline $\begin{array}{l}\text { Substituição e incorporação de novos } \\
\text { materiais }\end{array}$ & & & \\
\hline Demanda de pequenos lotes (específicos) & & & \\
\hline $\begin{array}{l}\text { Entender os requisitos dos clientes e } \\
\text { traduzir em termos técnicos }\end{array}$ & & & \\
\hline $\begin{array}{l}\text { Habilidade dos funcionários para lidar com } \\
\text { as flutuações em pedidos }\end{array}$ & & & \\
\hline Outros (especifique) & & & \\
\hline
\end{tabular}

16. A empresa considera que as relações estabelecidas com produtores de máquinas nos últimos anos ampliaram as condições para o desenvolvimento das suas informações técnicas internas?

Sim (1); Não (2). Por quê?

C) Efeitos das relações estabelecidas com produtores de máquinas para calçados 
17. Quais os principais resultados da mudança de produtos e processos para a empresa?

\begin{tabular}{|l|l|l|}
\hline \multicolumn{1}{|c|}{ Resultados } & \multicolumn{1}{|c|}{$\begin{array}{c}\text { Mudanças em } \\
\text { produtos }\end{array}$} & \multicolumn{1}{c|}{$\begin{array}{c}\text { Mudanças em } \\
\text { processos }\end{array}$} \\
\hline Aumento das vendas. & & \\
\hline Desenvolvimento de novos produtos. & & \\
\hline Aumento das exportações. & & \\
\hline Diversificação. & & \\
\hline Melhoria da qualidade. & & \\
\hline Redução dos custos. & & \\
\hline Adequação as normas nacionais. & & \\
\hline Adequação as normas estrangeiras. & & \\
\hline Adequar as exigências da demanda. & & \\
\hline Melhorar as condições de trabalho. & & \\
\hline $\begin{array}{l}\text { Melhorou as condições para } \\
\text { trabalhar com novos materiais. }\end{array}$ & & \\
\hline $\begin{array}{l}\text { Aumentou a base } \\
\text { microeletrônica/técnica. }\end{array}$ & & \\
\hline Outras. & & \\
\hline
\end{tabular}

18. Exemplifique as tecnologias ou práticas organizacionais associadas ao processo produtivo mais importante para a empresa ser competitiva na indústria:

Tecnologia de processo (1);

Práticas organizacionais (2).

19. As tecnologias de processo têm característica estável (1) ou estão em constante mudança (2)?

As práticas organizacionais têm característica estável (1) ou estão em constante mudança (2)?

20. Como a empresa acompanha as mudanças em tecnologias de processo e as mudanças nas práticas organizacionais?

21. As (s) mudanças (s) nas competências tecnológicas e organizacionais representaram novidades para: mercado mundial (1); mercado regional (2); mercado nacional (3); apenas para a empresa (4).

22. Quem desenvolveu/realizou essas mudanças: empresa de máquinas (1) empresa de calçados (2); concorrentes de calçados (3); parceiros (4); terceiros (5).

23. Onde foi desenvolvida essa competência: Brasil (1); principalmente no exterior (2) - qual o (s) país (países).

24. Como a concorrência com empresas de calçados (mercado externo) tem interferido nas relações com os produtores de máquinas nacionais? 


\section{ANEXO 6 - ROTEIRO DE QUESTÕES APLICADAS JUNTO ÀS INSTITUIÇÕES DE APOIO AO SETOR DE MÁQUINAS PARA CALÇADOS}

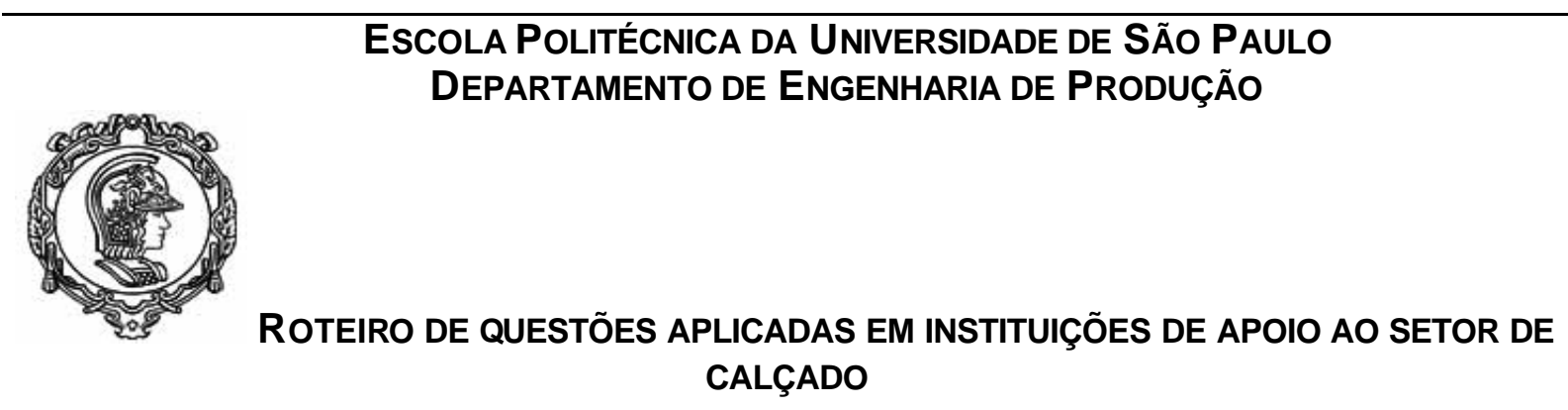

Data de realização da entrevista:

Tempo de duração:

1. Relações com usuários e fornecedores (caracterização dos fluxos de informação de produtos e processos);

2. Efeitos dos contatos firmados com os usuários do setor de calçados (o processo de criação, difusão e incorporação de capacitações internas às empresas de máquinas no longo prazo);

3. Potencial das relações usuário-produtor (criação de competências em empresas de outros segmentos da indústria calçadista no longo prazo);

4. Participação de outros agentes do mercado interno (fora do arranjo produtivo) e de outros países (principalmente Itália e China) no desenvolvimento de melhorias em projeto e produtos;

5. Atuação das instituições de apoio e pesquisa junto às empresas de máquinas visando o desenvolvimento de melhorias para o setor de calçados.

a) Características dos programas de apoio voltados ao desempenho comercial e o desenvolvimento tecnológico do setor de máquinas;

b) Dificuldades da atuação institucional junto às empresas de máquinas para calçados;

c) Perspectivas para o desenvolvimento das empresas de máquinas e dos SLPs de calçados frente à concorrência internacional; 